\title{
TSUNAMI INUNDATION MAPS OF PORT VALDEZ, ALASKA
}

\author{
by
}

D.J. Nicolsky, E.N. Suleimani, P.J. Haeussler, H.F. Ryan, R.D. Koehler, R.A. Combellick' and R.A. Hansen

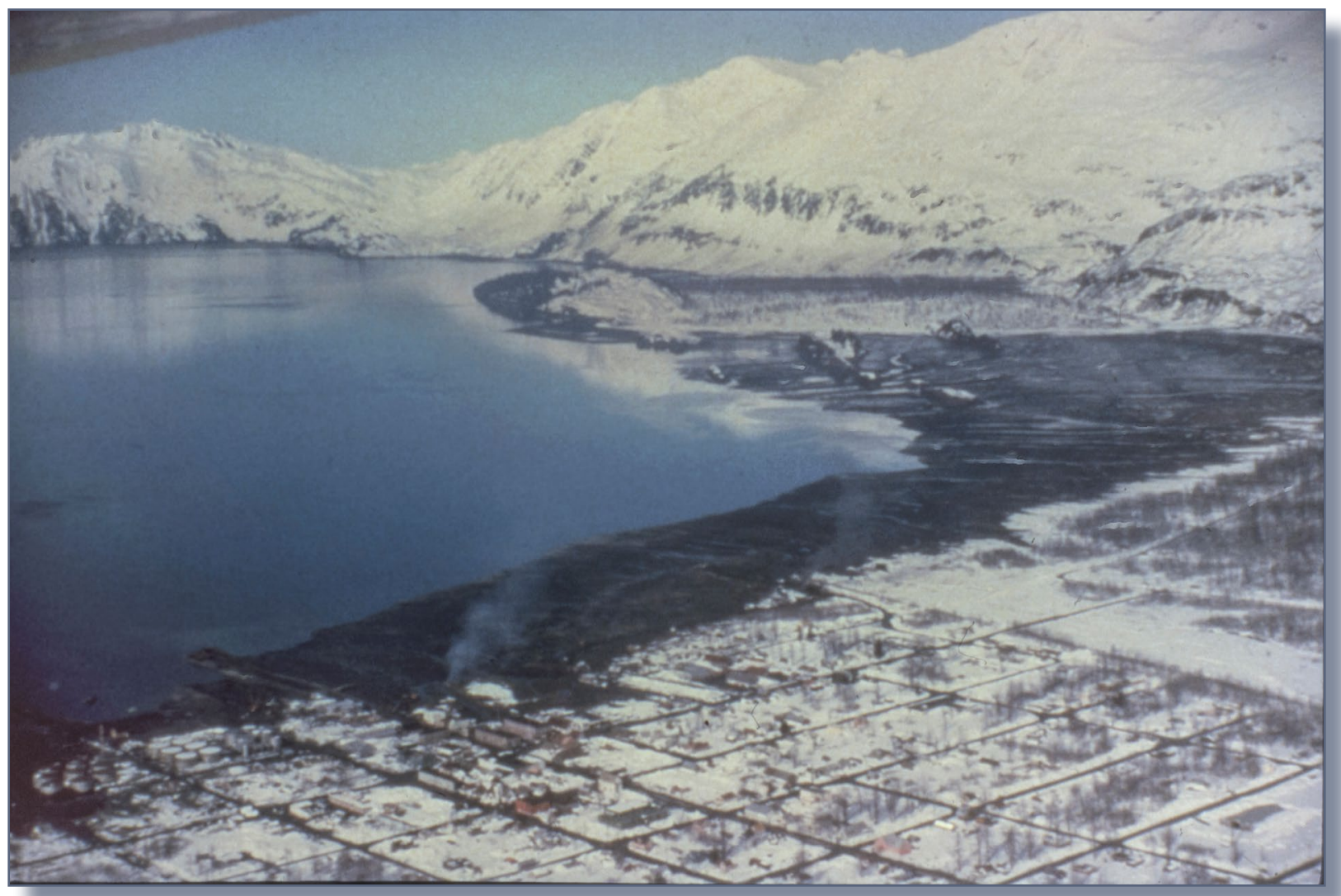

Aerial view of Valdez, Alaska, showing the extent of inundation along the coastline after the 1964 tsunami. Image courtesy of U.S. Department of the Interior.

\section{Published by}

STATE OF ALASKA

DEPARTMENT OF NATURAL RESOURCES

DIVISION OF GEOLOGICAL \& GEOPHYSICAL SURVEYS 



\section{Report of Investigations 2013-1}

\section{TSUNAMI INUNDATION MAPS OF PORT VALDEZ, ALASKA}

by

D.J. Nicolsky, E.N. Suleimani, P.J. Haeussler, H.F. Ryan,

R.D. Koehler, R.A. Combellick' and R.A. Hansen

2013

This DGGS Report of Investigations is a final report of scientific research.

It has received technical and scientific review and may be cited as an agency publication. 


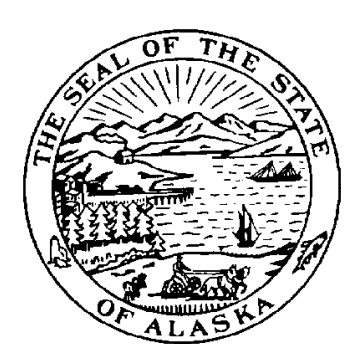

STATE OF ALASKA

Sean Parnell, Governor

DEPARTMENT OF NATURAL RESOURCES

Daniel S. Sullivan Commissioner

DIVISION OF GEOLOGICAL \& GEOPHYSICAL SURVEYS

Robert F. Swenson, State Geologist and Director

Publications produced by the Division of Geological \& Geophysical Surveys (DGGS) are available for free download from the DGGS website (www.dggs.alaska.gov). Publications on hard-copy or digital media can be examined or purchased in the Fairbanks office:

\section{Alaska Division of Geological \& Geophysical Surveys 3354 College Rd., Fairbanks, Alaska 99709-3707 \\ Phone: (907) 451-5020 Fax (907) 451-5050 \\ dggspubs@alaska.gov \\ www.dggs.alaska.gov}

Alaska State Library

State Office Building, 8th Floor 333 Willoughby Avenue

Juneau, Alaska 99811-0571

Elmer E. Rasmuson Library

University of Alaska Fairbanks

Fairbanks, Alaska 99775-1005
Alaska Resource Library \& Information Services (ARLIS)

3150 C Street, Suite 100

Anchorage, Alaska 99503-3982

University of Alaska Anchorage Library 3211 Providence Drive

Anchorage, Alaska 99508-4614 


\section{CONTENTS}

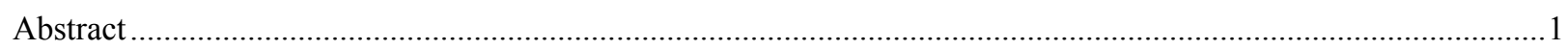

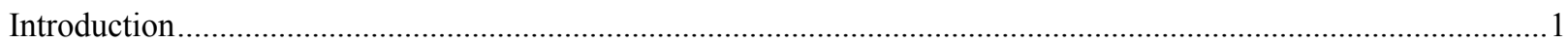

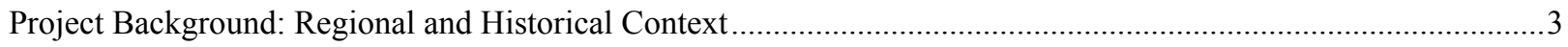

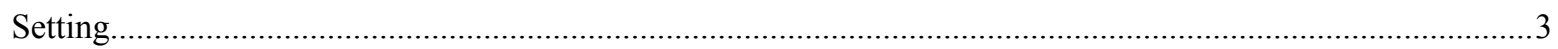

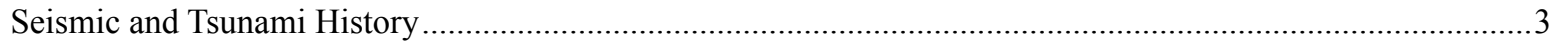

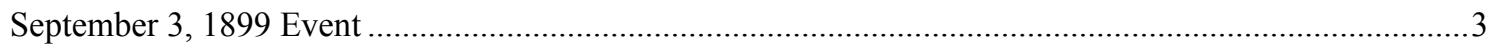

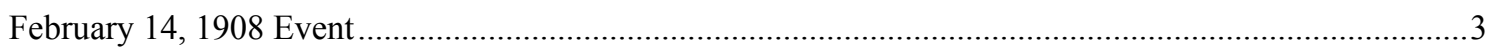

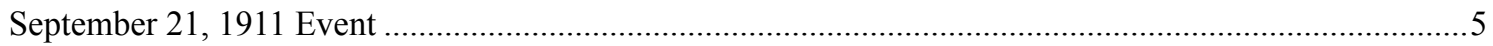

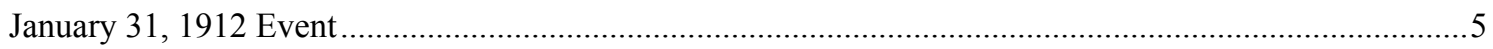

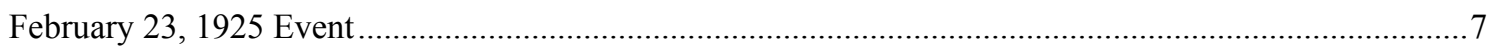

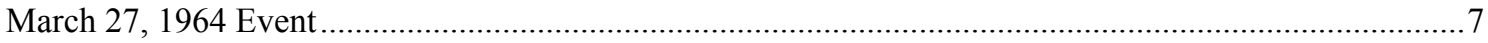

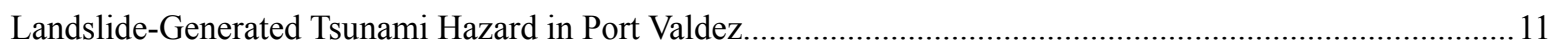

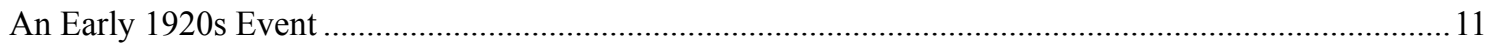

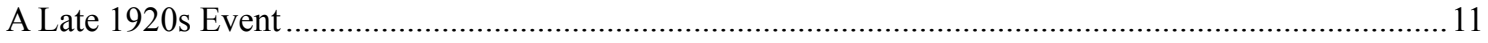

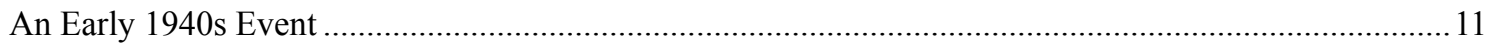

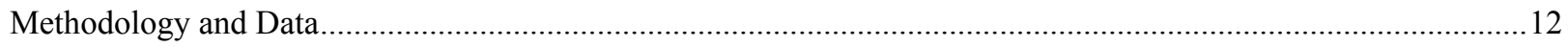

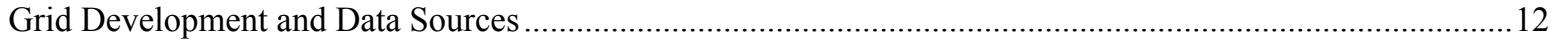

Development of the Pre- and Post-Earthquake Bathymetry and the 1964 Slide Configuration .......................14

Numerical Model of Tsunami Propagation and Runup ..................................................................

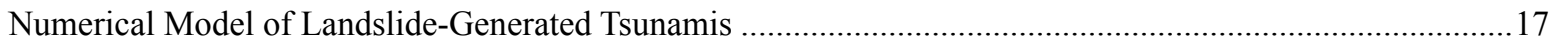

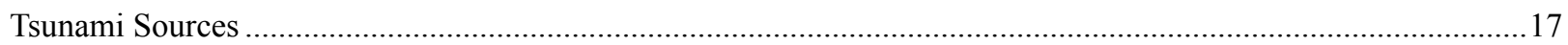

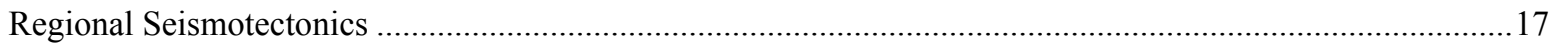

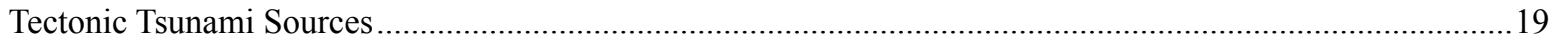

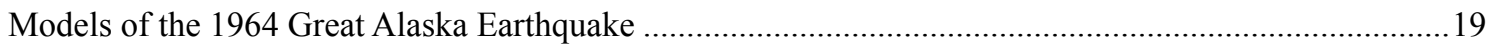

Scenario 1. Repeat of the 1964 event: Source function based on coseismic deformation model by

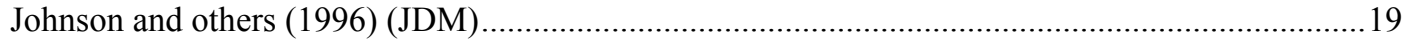

Scenario 2. Repeat of the 1964 event: Source function based on coseismic deformation model by

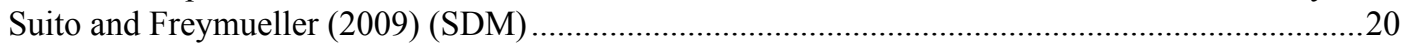

Models of the Multi-Segment Great Alaska Earthquake ...............................................................20

Scenario 3. Multi-Segment JDM event: Source function based on extension of the JDM................20

Scenario 4. Multi-Segment SDM event: Source function based on extension of the SDM ................20

Scenario 5. Rupture of the Yakutat-Yakataga segment .................................................................20

Model of the Cascadia Subduction Zone Earthquake ...........................................................................20

Scenario 6. Rupture of the Cascadia zone, including portions of the margin along the British

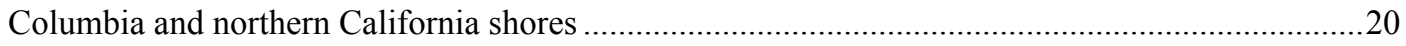

Tectonic Source Models of Hypothetical Tsunamigenic Earthquakes ................................................20

Scenario 7. Modified 1964 event: Prince William Sound asperity of the JDM ................................21

Scenario 8. Modified 1964 event: Kodiak asperity of the JDM.................................................21

Scenario 9. Modified 1964 event: Prince William Sound asperity of the SDM .............................21 
Scenario 10. Modified 1964 event: Kodiak asperity of the SDM

Other Tectonic Source Models of Hypothetical Tsunamigenic Earthquakes..............................................21

Scenario 11. Modified multi-segment JDM event: Rupture of the PWS and YY segments .................21

Scenario 12. Modified multi-segment SDM event: Rupture of the PWS and YY segments ................21

Tectonic Source Models of Hypothetical Tsunamigenic Earthquakes with a Subsidence in Port Valdez ...21

Scenario 13. $\mathrm{M}_{\mathrm{w}} 8.8$ earthquake in the Gulf of Alaska region: 17-30 km (10.5-18.6 mi), uniform

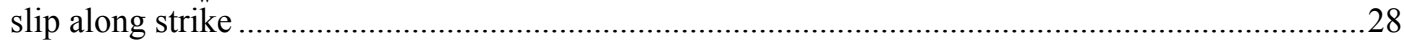

Scenario 14. $\mathrm{M}_{\mathrm{w}} 8.8$ earthquake in the Gulf of Alaska region: 13-28 km (8.1-17.4 mi), variable

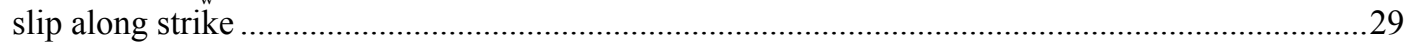

Scenario 15. $\mathrm{M}_{\mathrm{w}} 8.8$ earthquake in the Gulf of Alaska region: $12-29 \mathrm{~km}$ (7.5-18 mi), variable slip along strike......

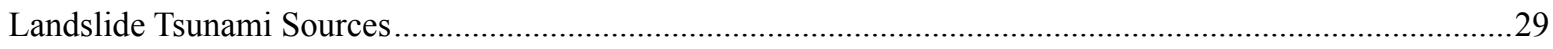

Multiple Submarine Slope Failures in Port Valdez During the 1964 Earthquake.

Scenario 16. Repeat of the 1964-type event: An underwater slide at the head of Port Valdez (HPV slide)

Scenario 17. Repeat of the 1964-type event: An underwater slide at the Shoup Bay moraine

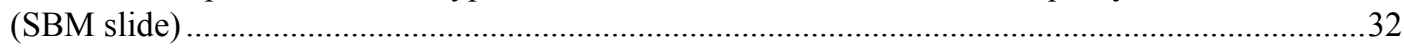

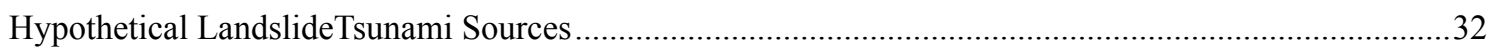

Scenario 18. Hypothetical event: An underwater slide offshore of Mineral Creek (MC slide).............32

Scenario 19. Hypothetical event: An underwater slide offshore of Gold Creek (GC slide) ...................32

Scenario 20. Hypothetical event: An underwater slide offshore of Lowe River (LR slide) ..................32

Scenario 21. Hypothetical event: An underwater slide at Shoup Bay moraine (SBM residual

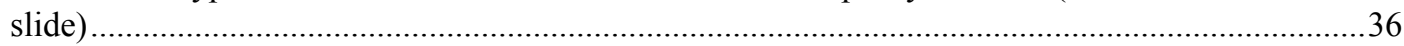

Scenario 22. Hypothetical event: Simultaneous failure of underwater slide complexes described

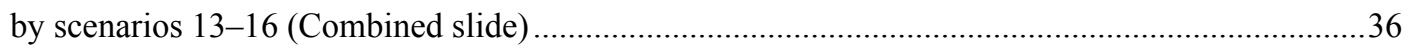

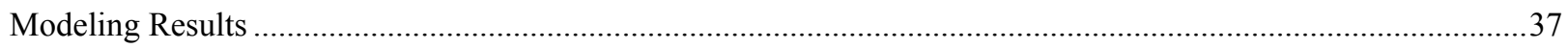

Numerical Modeling of the 1964 Tsunami in Port Valdez: Model Verification................................................37

Modeling the Landslide-Generated Tsunami at the Old Town Waterfront ...................................................37

Modeling the Tectonic Tsunami at the Old Town Waterfront .....................................................................4

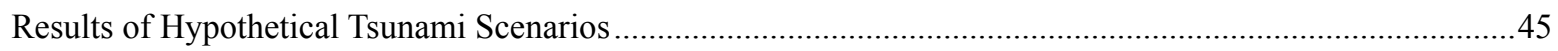

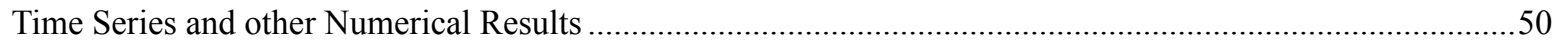

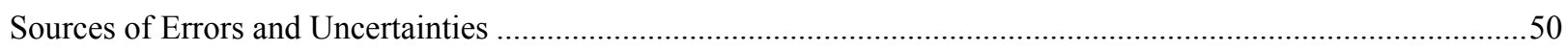

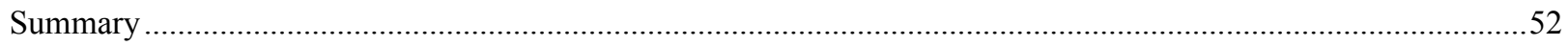

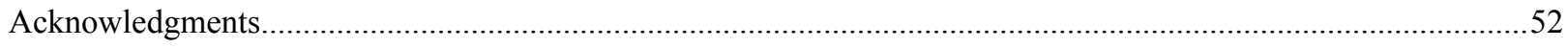

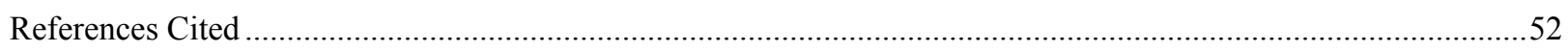

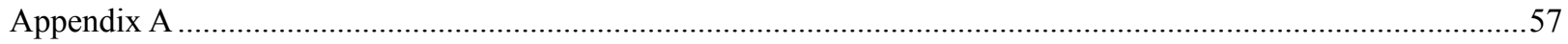

\section{FIGURES}

Figure 1. Map of south-central Alaska, identifying major active or potentially active faults and the rupture zone of the 1964 Great Alaska Earthquake.

2. Topographic map of Port Valdez, showing the old townsite (Old Valdez) and the present-day location of the city, as well other sites referred to in the main body of report.. 
3. Earthquakes in south-central Alaska, from the Alaska Earthquake Information Center catalog..... .5

4. Schematic view of Port Valdez, showing submarine cables connecting Valdez to Sitka and Seward.........6

5. Distribution and intensity of wave damage in Port Valdez after the 1964 earthquake, mapped by L. Mayo and G. Plafker

6. Plan of the old town after the 1964 earthquake, showing the tsunami inundation and post-earthquake bathymetry profiles

7. Nesting of bathymetry/topography grids for numerical modeling of tsunami propagation and runup ......13

8. Reconstructed initial thickness of the Shoup Bay the old town slides during the 1964 earthquake........... 16

9. Map of south-central Alaska, showing the rupture zone of the 1964 Great Alaska Earthquake and divisions of the Alaska-Aleutian megathrust: Prince William Sound, Kodiak Island, and YakatagaYakutat segments

10. Vertical deformations of the ocean floor and adjacent coastal region in meters, corresponding to scenarios $1-12$.

11. Interpolated plate interface depth (in kilometers) between Kodiak Island and Prince William Sound.....24

12. Discretization of the plate interface model into a set of rectangles used to compute the coseismic vertical displacement by Okada's (1985) formulae

13. Assumed down-dip slip distribution for cases A and B . .25

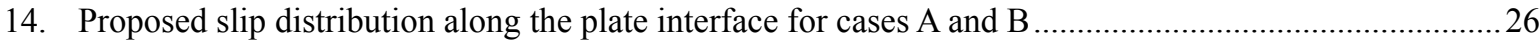

15. Computed vertical ground surface deformation related to cases $\mathrm{A}$ and $\mathrm{B}$.............................................2

16. Contour plot of the interseismic slip deficit reconstruction, with contour interval of $1 \mathrm{~cm}(0.39 \mathrm{in})$ per year.

17. Proposed slip distribution at the plate interface in the along-strike direction is parameterized according to Suito and Freymueller's 2009 slip-deficit model

18. Computed vertical ground-surface deformation related to cases A and B

19. Illustrations showing initial thickness of the different realizations of the HPV landslide according to sub-scenarios of scenario 16

20. Illustrations showing initial thickness of the different realizations of the SBM landslide according to sub-scenarios of scenario 17 .

21. Illustrations showing initial thickness of (A) Mineral Creek slide (scenario 18); (B) Gold Creek slide (scenario 19); (C) Shoup Bay residual slide (scenario 20); and (D) the 1966-2003 sediment accumulation (scenario 21)

22. Schematic drawing of the city harbor (A) before the 1964 earthquake; (B) after the earthquake and during the landslide-generated tsunami; and $(\mathrm{C})$ at present

23. Sensitivity of inundation by the $\mathrm{HPV}_{64}$ slide-generated tsunami in the old townsite with respect to the parameterization of the bottom drag

24. Maximum computed runup caused by (A) $\mathrm{HPV}_{64}$ and (B) $\mathrm{SBM}_{64}$ slide-generated tsunamis in Port Valdez during the 1964 event.

25. Modeled water level above ground at points 37, 38, and 39 along Alaska Avenue during the 1964 tsunami, and at point 36, in Valdez Narrows

26. Reconstructed tide level, modeled water-level dynamics, and tide-corrected simulated water level at point 37 during the 1964 tectonic tsunami, based on the SDM and JDM

27. Reconstructed tide level, modeled water depth, and tide-corrected simulated water depth at point 39 during the 1964 tectonic tsunami, based on the SDM and JDM

28. Observed and modeled 1964 inundation caused by tectonic- and landslide-generated waves 
29. Computed water-level dynamics at point 24 , in eastern Port Valdez, according to scenarios 1,3 ,

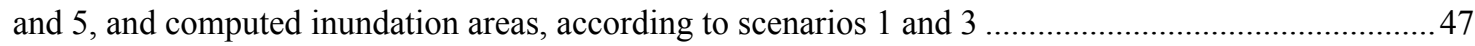

30. Modeled potential inundation by tectonic waves for selected scenarios ..................................................4

31. Modeled potential inundation by landslide-generated waves for all sub-scenarios of scenario $16 \ldots \ldots \ldots . . .49$

32. Modeled potential inundation by landslide-generated wave for all considered scenarios..........................51

\section{TABLES}

Table 1. Fault parameters for the Yakataga-Yakutat (YY) segment.............................................................. 12

2. Nested grids used to compute propagation of tsunamis generated in the Gulf of Alaska to the

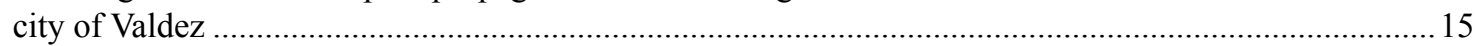

3. All hypothetical scenarios used to model tsunami runup in Port Valdez....................................................36

\section{APPENDICES}

\section{Appendix A}

FigureA-1. Locations of time series points in western and eastern Port Valdez. .57

A-2. Time series of water level and velocity at selected locations for scenarios $16-22$.......................58

A-3. Time series of water level and velocity at selected locations for scenarios $1,3,6$, and $14 \ldots \ldots \ldots . .68$

Appendix B Maximum composite potential inundation extent from all tectonic- and landslide-generated scenarios, and maximum composite flow depths over dry land .79

\section{SHEET}

(in envelope)

Sheet 1. Tsunami Inundation, Port Valdez, Alaska 


\title{
TSUNAMI INUNDATION MAPS OF PORT VALDEZ, ALASKA
}

\author{
by \\ D.J. Nicolsky ${ }^{1}$, E.N. Suleimani ${ }^{1}$, P.J. Haeussler ${ }^{2}$, H.F. Ryan², \\ R.D. Koehler ${ }^{4}$, R.A. Combellick ${ }^{4}$, and R.A. Hansen ${ }^{1}$
}

\begin{abstract}
We evaluate potential tsunami hazards for the city of Valdez and numerically model the extent of inundation from tsunamis generated by earthquake and landslide sources. Tsunami scenarios include a repeat of the tsunami triggered by the 1964 Great Alaska Earthquake, as well as hypothetical tsunamis generated by an extended 1964 rupture, a Cascadia megathrust earthquake, and earthquakes from the Prince William Sound and Kodiak asperities of the 1964 rupture. Local underwater landslide events in Port Valdez are also considered as credible tsunamigenic scenarios. Results of numerical modeling are verified by simulating the tectonic and landslide-generated tsunamis in Port Valdez observed during the 1964 earthquake. The results of these tsunami scenarios are intended to provide guidance to local emergency management agencies in tsunami hazard assessment, evacuation planning, and public education for reducing future casualties and damage from tsunamis.
\end{abstract}

\section{INTRODUCTION}

Subduction of the Pacific plate under the North American plate has resulted in numerous great earthquakes and still has the greatest potential to generate tsunamis in Alaska. The Aleutian megathrust (fig. 1), where the Pacific plate is being subducted, is the most seismically active tsunamigenic fault zone in the U.S. Several historic tsunamis generated by earthquakes along the Alaska-Aleutian subduction zone traveled across the Pacific Ocean and impacted exposed shorelines, which resulted in widespread damage and loss of life. However, tsunamis originating in the vicinity of the Alaska Peninsula, Aleutian Islands, and Gulf of Alaska are also considered to be a near-field hazard for Alaska, and can reach Alaska's coastal communities within minutes of the earthquake. Saving lives and property depends on how well a community is prepared, which further depends on understanding the potential flooding of the coastal zone in the event of a local or distant tsunami.

On March 27, 1964, the Prince William Sound area of Alaska was struck by the largest earthquake ever recorded in North America. This $\mathrm{M}_{\mathrm{w}} 9.2$ megathrust earthquake generated the most destructive tsunami in Alaska history and, farther south, impacted the west coast of the United States and Canada. In addition to the major tectonic tsunami generated by an ocean floor displacement between the trench and coastline, more than 20 local tsunamis were generated by submarine landslides in coastal Alaska. They arrived within minutes after shaking was felt, leaving no time for warning or evacuation. Of the 131 fatalities associated with this earthquake, 122 were caused by tsunamis (Lander, 1996). Local tsunamis caused most of the damage and accounted for 76 percent of tsunami fatalities in Alaska. The city of Valdez in Port Valdez suffered greatly from both the local landslide-generated waves and the tectonic tsunami, which originated in the Gulf of Alaska. The city sustained great damage, and more than 30 people died from tsunami-related causes. Because the local landslide-generated tsunami was responsible for most of the damage to the city during the earthquake, the potential occurrence of similar events must be evaluated to enable comprehensive inundation mapping efforts and development of tsunami evacuation maps.

The production of tsunami evacuation maps for a community consists of several stages. First, we develop hypothetical tsunami scenarios on the basis of credible potential tsunamigenic earthquakes and submarine landslides. Then we perform model simulations for each of these scenarios. We compare the results with historical tsunami observations, if such data exist. Finally, we develop a "worst case" inundation line that encompasses the maximum extent of flooding based on model simulation of all credible source scenarios and historical observations. The "worst case" inundation line becomes a basis for local tsunami hazard planning and development of evacuation maps.

The tsunami inundation maps of Valdez described in this report represent the results of the continuous effort between state and federal agencies ${ }^{5}$ to produce inundation maps for many of Alaska's coastal communities. In this report, we generally provide both metric and imperial units of measure. If it is necessary to quote some existing data, we state the data in the original and metric units of measure. Recall that one foot $(1 \mathrm{ft})$ is approximately 0.305 meters $(0.305 \mathrm{~m})$, and one mile $(1 \mathrm{mi})$ is approximately 1.609 kilometers $(1.609 \mathrm{~km})$.

\footnotetext{
${ }^{1}$ Alaska Earthquake Information Center, Geophysical Institute, University of Alaska, P.O. Box 757320, Fairbanks, AK 99775-7320

${ }^{2}$ U.S. Geological Survey, 4210 University Drive, Anchorage, AK 99508

${ }^{3}$ USGS Pacific Coastal \& Marine Science Center, 345 Middlefield Road MS 999, Menlo Park, CA 94025

${ }^{4}$ Alaska Division of Geological \& Geophysical Surveys, 3354 College Rd., Fairbanks, AK 99709-3707

${ }^{5}$ To help mitigate the hazard that earthquakes and tsunamis pose to Alaska coastal communities, the Alaska Tsunami Mapping Team (ATMT) was created. It consists of personnel from the Geophysical Institute at the University of Alaska Fairbanks and from the State of Alaska Division of Geological \& Geophysical Surveys. The ATMT participates in the National Tsunami Hazard Mitigation Program by evaluating and mapping potential inundation of selected parts of the Alaska coastline using numerical tsunami modeling.
} 


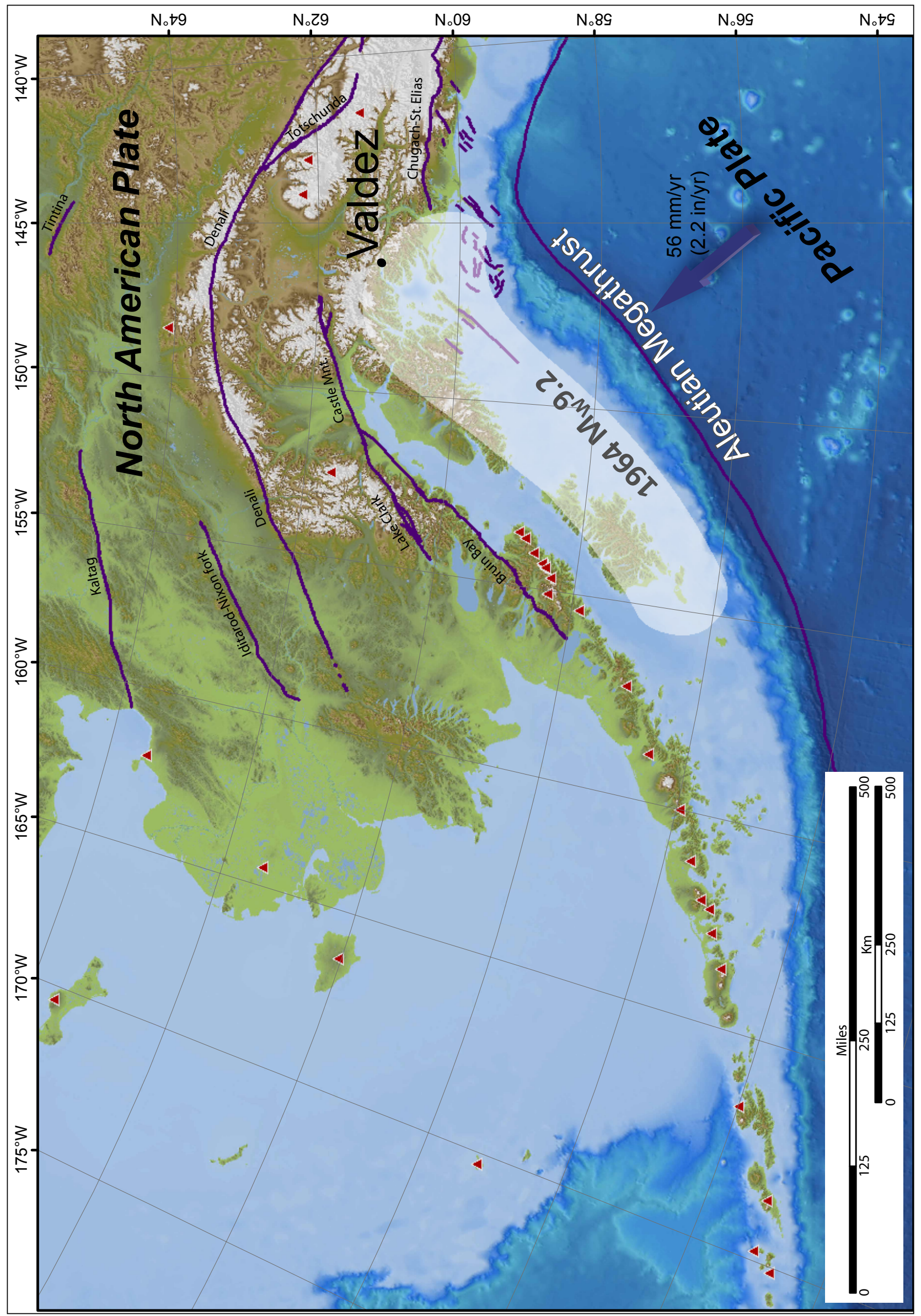

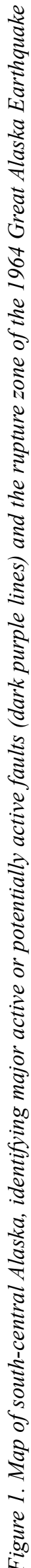




\section{PROJECT BACKGROUND: REGIONAL} AND HISTORICAL CONTEXT

\section{Setting}

Valdez is on the northeastern shore of Port Valdez, about $185 \mathrm{~km}(115 \mathrm{mi})$ east of Anchorage and $75 \mathrm{~km}(47 \mathrm{mi})$ northwest of Cordova, at approximately $61^{\circ} 08^{\prime} \mathrm{N}$ latitude and $146^{\circ} 21^{\prime} \mathrm{W}$ longitude. The retreat of glaciers that carved Port Valdez left a steep-walled, U-shaped fjord stretching from east to west and measuring about $22 \mathrm{~km}(14 \mathrm{mi})$ in length, and $5 \mathrm{~km}(3 \mathrm{mi})$ in width. The fjord extends to Valdez Narrows in the southwest, Shoup Bay in the northwest, and the Lowe River valley and Valdez Glacier Stream bed in the east. The city of Valdez originated in 1898 as a starting point for prospectors en route to the gold mines in Klondike and the Eagle mining district. The original settlement was established at the eastern shore of Port Valdez on the outwash plains of the Lowe River and Valdez Glacier Stream. These plains provided a convenient location for offloading people and supplies for gold mining, and thus the geography promoted rapid growth of the settlement. Because Port Valdez is the northernmost ice-free port in Alaska, it was selected in 1899 as a terminus for the Richardson Highway, which connected the city to the interior of Alaska. Following the highway construction, Valdez has been a focal point for the flow of supplies and equipment from tidewater to Anchorage, Fairbanks, and the interior of Alaska.

The city was severely damaged by the 1964 earthquake and tsunami. The loss of a major port facility, coupled with destruction of ports in Seward and Whittier, impeded postearthquake supply distribution to other earthquake-affected areas such as Anchorage and Fairbanks. Subsequent to the earthquake, a subsurface investigation by the Alaska Department of Highways revealed that the outwash plains were composed of poorly consolidated water-saturated alluvial sediments. During the 1964 event, the sediments along the shore liquefied and slid into the bay, generating the local tsunami that destroyed the city waterfront. It was established that the original location of the town was not suitable, and thus under supervision of the U.S. Army Corps of Engineers, the city of Valdez was relocated onto a more stable foundation $6.5 \mathrm{~km}(4 \mathrm{mi})$ west of its original position. The original and current locations of the city are labeled in figure 2 by names Old Valdez and Valdez, respectively. The current location of the city is on an alluvial fan formed by Mineral Creek. Here, the sediments are deposited in an elongated depression between the main valley wall and a parallel, outlying bedrock ridge that forms a series of ribs and islands along the north shore. These serve to confine the alluvial sediments to the seaward side of the fan.

The city of Valdez has developed considerably since the 1964 earthquake. In the 1970s, construction of the TransAlaska Pipeline System (TAPS) oil terminal and other cargo transportation facilities brought rapid growth to the city. The present-day economy is diversified and includes tourism, commercial fishing, fish processing, hatchery facilities, and a refinery, as well as infrastructure for offloading onto tanker ships the oil extracted from Prudhoe Bay on the North Slope.
Valdez hosts several cruise ship dockings per year, serves as a Coast Guard station, and is a port for the Alaska Marine Highway System. Its availability as an ice-free harbor, together with its $\$ 48$ million cargo and container facility, make Valdez an important seaport. Much of the economic activity and infrastructure is on or near the coast, ports, and harbors, and hence is vulnerable to potential tsunamis.

\section{Seismic and tsunami history}

Port Valdez is at the southern flank of the Chugach Range, underlain by metasedimentary rocks of the Valdez Group, near a plate boundary where the Pacific and North American plates converge along the Alaska-Aleutian megathrust at a rate of up to $56 \mathrm{~mm}$ (2.2 in) per year (DeMets and others, 1990; Page and others, 1991). Valdez is in the northeastern section of the Alaska-Aleutian megathrust, where the megathrust is strongly coupled and has a shallow dip angle of about 8-10 degrees in the Kodiak Island area and 3-4 degrees in the Prince William Sound area (Brocher and others, 1994). This segment of the megathrust has produced some of the largest earthquakes in the world, such as the $\mathrm{M}_{\mathrm{w}} 9.2$ Great Alaska Earthquake of 1964 that caused a $285,000 \mathrm{~km}^{2}\left(110,000 \mathrm{mi}^{2}\right)$ area of surface deformation (Plafker, 1969).

Figure 3 shows seismic activity in south-central Alaska with locations determined by the Alaska Earthquake Information Center (AEIC) at the University of Alaska Fairbanks. Doser and Brown (2001) find that the central and southern Kenai Peninsula have been seismically quiet at the $M_{w} \geq 5$ level since the 1964 event, while the Prince William Sound area continues to experience seismic activity similar to that prior to the 1964 earthquake. More than 70 earthquakes of recorded or estimated $M_{w} \geq 5$ have been felt in Valdez since 1898. Besides the $\mathrm{M}_{\mathrm{w}} 9.2$ Great Alaska Earthquake, five historic earthquakes are of special interest to tsunami hazard mitigation in Valdez. Relative locations of these five significant earthquakes, as well as the 1964 earthquake, with respect to Port Valdez are shown in figure 3. Descriptions of these events in Valdez are as follows.

\section{$\diamond$ September 3, 1899 Event}

During the $\mathrm{M}_{\mathrm{s}} 7.9$ Cape Yakataga earthquake in the region off of Yakataga (fig. 3; Doser, 2006), shaking was felt in Valdez to the extent "that men were made dizzy and could not stand, houses and forests were disturbed, and there were earthquake water waves in Port Valdez" (Tarr and Martin, 1912, p. 66). There was also a report stating that a ship, docked near the Lowe River in $12 \mathrm{~m}$ ( $40 \mathrm{ft}$ ) of water, could not anchor at the same spot with $60 \mathrm{~m}(200 \mathrm{ft})$ of cable after the earthquake (Coulter and Migliaccio, 1966), which suggests there was a significant submarine landslide at this location.

\section{$\diamond$ February 14, 1908 Event}

Ground shaking in Valdez lasted two minutes from this $M_{S} 6.0$ earthquake (fig. 3). The epicenter was located at $61^{\circ} \mathrm{N}$ latitude and $147^{\circ} 12^{\prime} \mathrm{W}$ longitude (NGDC/WDC Global Historical Tsunami Database, 2012). Grant and Higgins, (1913, p. 12) found that several submarine cables were broken, and concluded that this was due to slumping of the delta front. The 


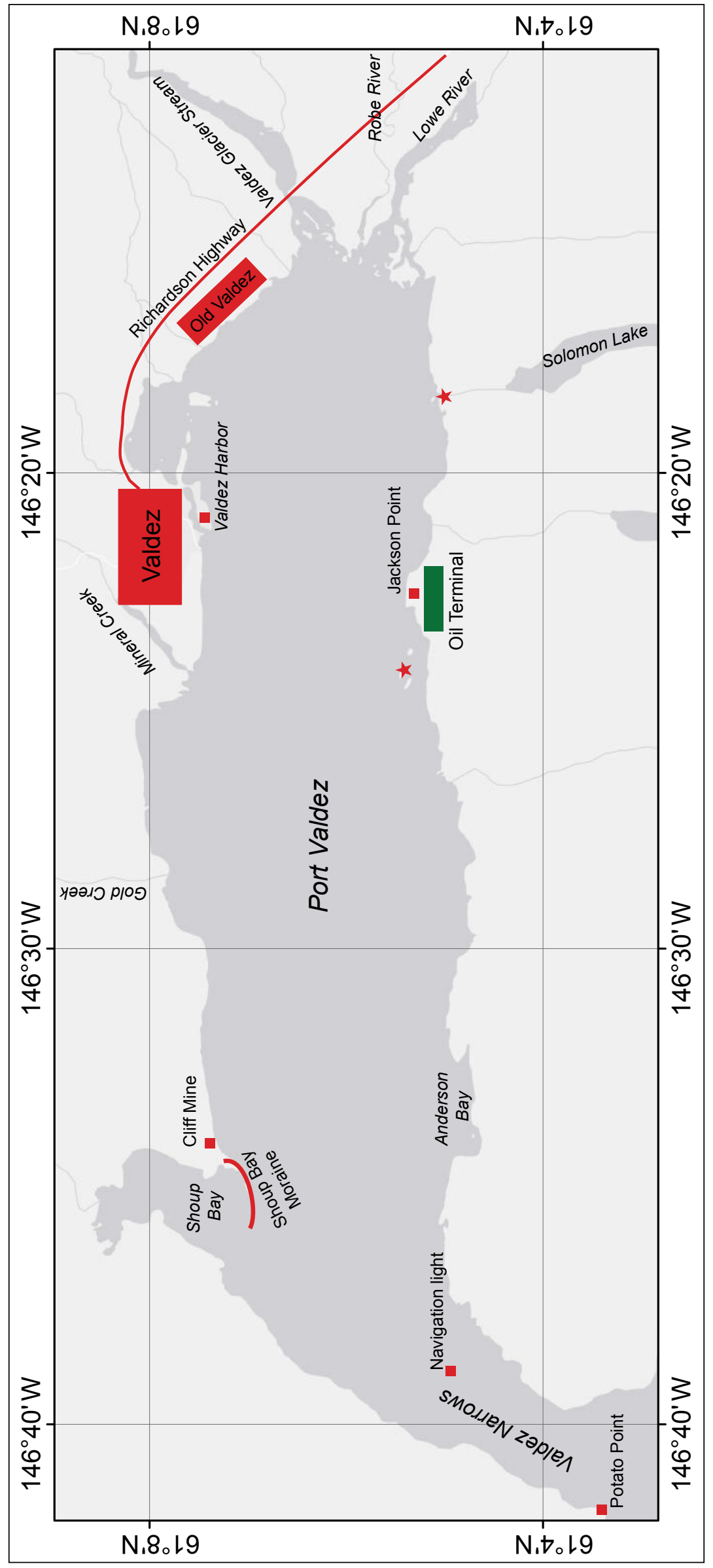

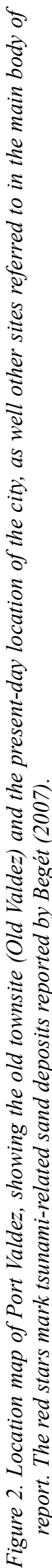




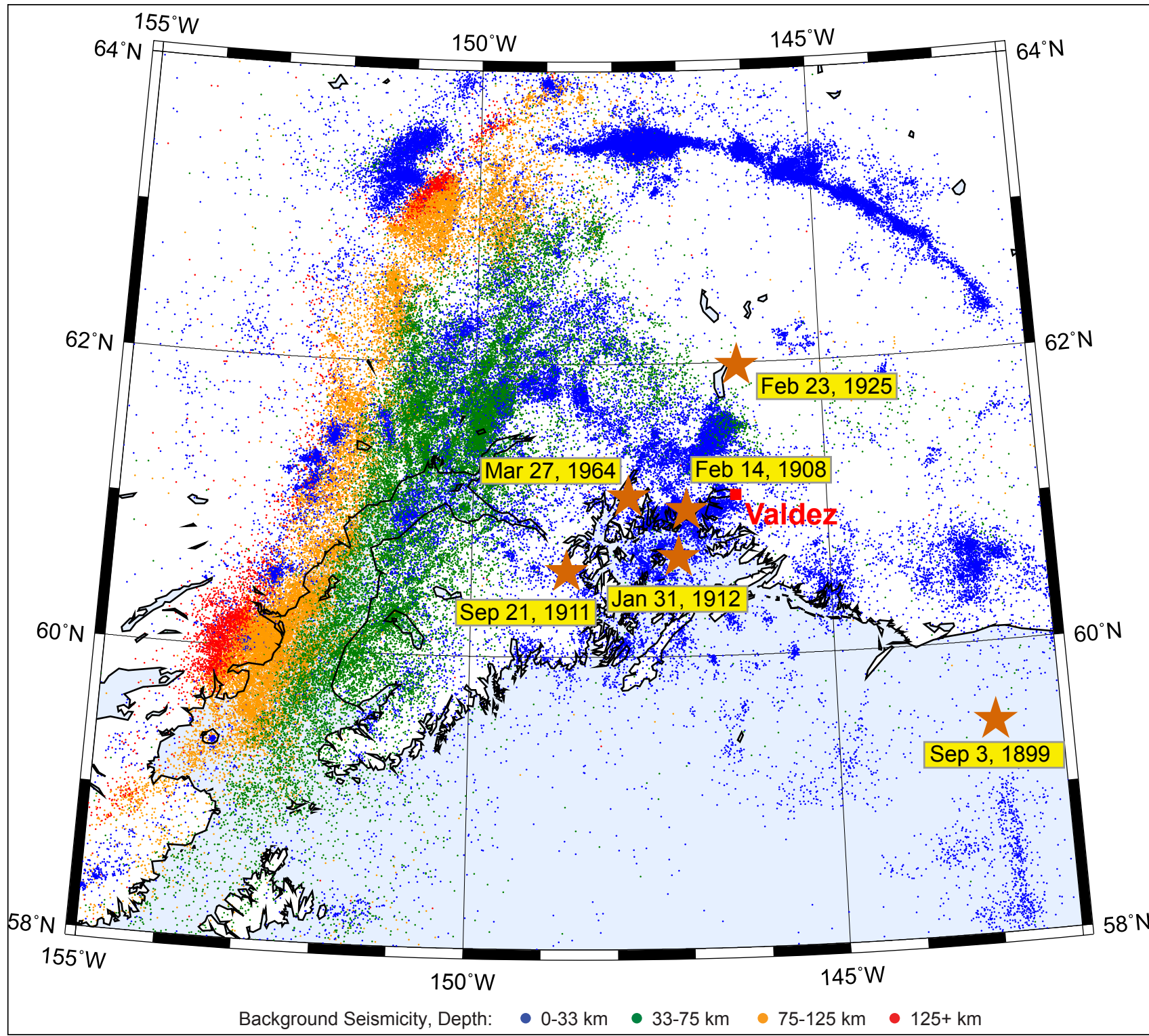

Figure 3. Earthquakes in south-central Alaska, from the Alaska Earthquake Information Center catalog. Dots correspond to earthquakes with magnitude less than 5. Aftershocks of the March 27, 1964, event are not included in the plot. Stars correspond to the six earthquakes associated with water disturbances in Port Valdez.

cables were broken close to the city of Valdez, inside Valdez Narrows. Locations of the breaks are shown in figure 4. In addition, the steamer Northwestern, while approaching the dock, encountered a 'tidal wave' large enough to make the boat rock very perceptibly (Tarr and Martin, 1912, p. 98).

\section{September 21, 1911 Event}

This $M_{s} 6.9$ earthquake had an epicenter beneath western Prince William Sound (Doser, 2006). It was a series of four shocks of different duration in the northwest-southeast direction. The ground shaking had sufficient intensity to throw some household articles from shelves. According to Tarr and Martin (1912, p. 100), “...during this earthquake the submarine cable from Valdez to Sitka was broken just north of Fort
Liscum, at a point $5.1 \mathrm{~km}(3.19 \mathrm{mi})$ west of the dock at Valdez, near latitude $61^{\circ} 06^{\prime} 08^{\prime \prime} \mathrm{N}$, and longitude $146^{\circ} 19^{\prime} 23^{\prime \prime} \mathrm{W}$, and was buried for $500 \mathrm{~m}(1,640 \mathrm{ft})$. This is almost exactly at one of the locations where the cable was broken during the earthquake of February 14, 1908. Curiously, the operator at Valdez said that the cable was not broken immediately, but that communication continued with Sitka some seconds after the earthquake shock. He was telegraphing to Sitka at the time of the shock."

\section{- January 31, 1912 Event}

The $\mathrm{M}_{\mathrm{S}} 7.2$ earthquake occurred in the middle of Prince William Sound (Doser, 2006). The submarine cables were again broken in Port Valdez. 


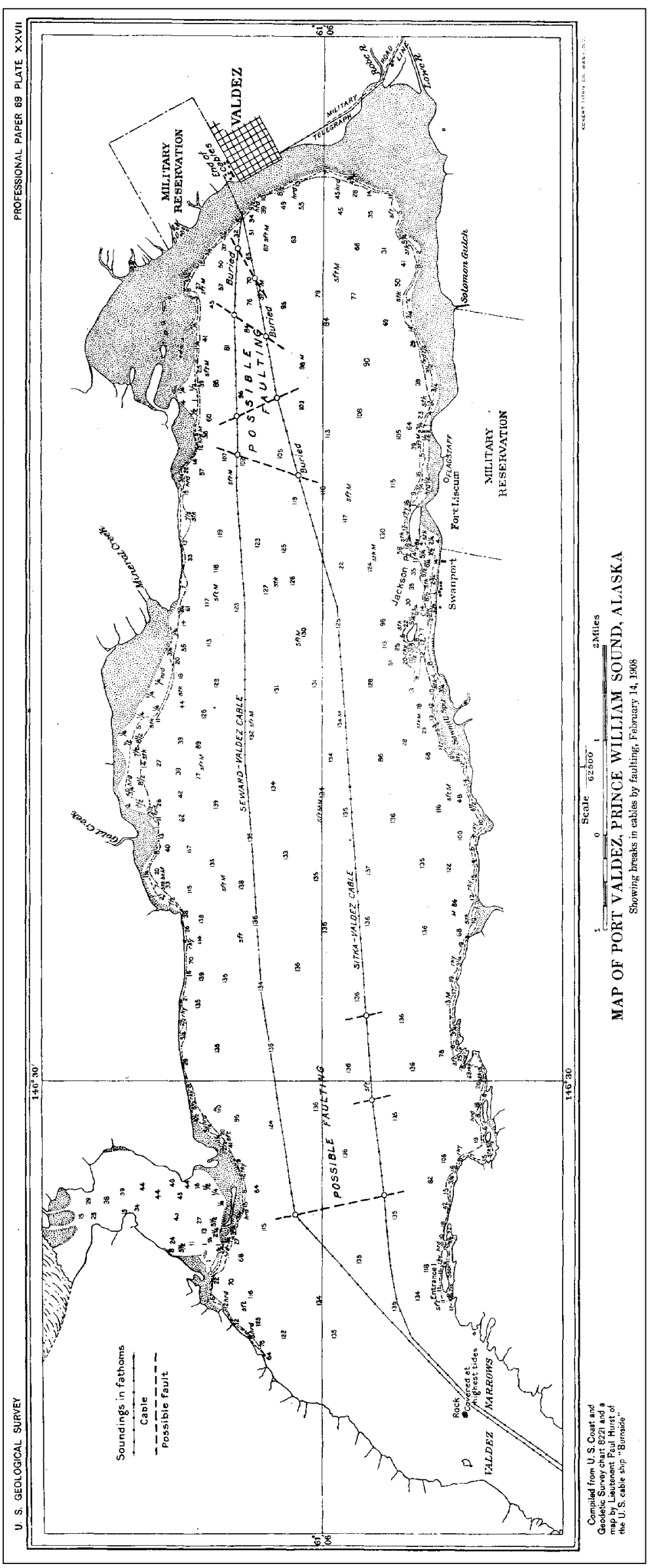

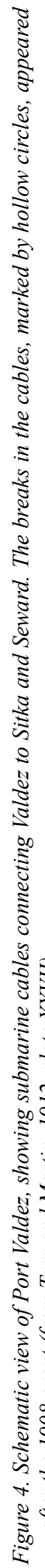




\section{$\diamond$ February 23, 1925 Event}

The earthquake occurred west of Glennallen and Copper Center, Alaska. Doser (2009) provides constraints on the earthquake intensity, epicenter location, and magnitude. Strong shaking and structural damage were reported in Valdez. A part of the dock collapsed into the bay, and an unusual wave accompanying the tremors tore up a section of the boardwalk along Water Street. The submarine cables were broken again (according to Gov. William A. Egan, in Coulter and Migliaccio, 1966).

\section{$\diamond$ March 27, 1964 Event}

The following account of the earthquake is taken from Coulter and Migliaccio (1966) unless otherwise noted. A minute-by-minute description is given by Chance (1972).

The $\mathrm{M}_{\mathrm{w}} 9.2$ Alaska earthquake of 5:36 p.m. March 27, 1964, at Valdez was characterized by a strong, rapid, rolling motion lasting from three to five minutes, during which people had great difficulty standing. The ground surface was heaving and subsiding like a swell in the open ocean, except more frequent and rapid. The post-earthquake studies by the U.S. Geological Survey (USGS) determined that the land subsided in Valdez by about $0.3-0.6 \mathrm{~m}(1-2 \mathrm{ft})$, and shifted laterally by $4.8-5.7 \mathrm{~m}(16-19 \mathrm{ft})$ in a southeast direction (Plafker and others, 1969). Some part of the Valdez waterfront subsided an additional $2.1-2.4 \mathrm{~m}(7-8 \mathrm{ft})$ due to the ground compaction and became prone to the inundation by a high tide. At the time of earthquake, the tide was near its low level; the predicted low tide for March 27, 1964, was $-0.18 \mathrm{~m}(-0.6 \mathrm{ft})$ at $6: 19 \mathrm{p} . \mathrm{m}$., and the predicted high tide for March 28 was $3.8 \mathrm{~m}(12.4 \mathrm{ft})$ at 12:42 a.m.

The great disaster during the earthquake happened in the dock and harbor area, where a massive submarine landslide generated a tsunami, inundating the waterfront up to two blocks inland. It is estimated that approximately 75 million $\mathrm{m}^{3}$ (98 million $\mathrm{yd}^{3}$ ) of unconsolidated deposits were transferred from the waterfront into the bay (Coulter and Migliaccio, 1966). We discuss other estimates of the slide volume later in this report. The slide and slide-generated waves were responsible for the deaths of 30 people at the city dock. Two men were killed by falling cargo and another died because of a heart attack. Valdez, similar to many coastal communities damaged by the 1964 earthquake, does not have a marigram record of the tsunami. The events and a sequence of waves are reconstructed from eyewitness reports and observations. Therefore, there are inherent uncertainties in the following estimates of wave time arrivals and wave heights. For example, due to severe shaking and presence of the ground surface waves, the estimated height of the landslide-generated tsunami might be biased by meters. Arrival of the tectonic waves, which flooded the city late at night, might have uncertainty of tens of minutes.

In the evening on March 27, 1964, the 10,815-ton M/V Chena was unloading freight at the Valdez dock. Shortly after the first shock, the ship became untethered and started to swirl in the waves. An in-depth analysis of the M/V Chena motion during the earthquake is given by Wilson and Tørum (1972). According to the authors, the ship initially went astern with the water withdrawal that accompanied the initial subsidence of the docks. Chena then rose by 6-9 m (20-30 ft) on an incoming wave and bottomed at the previous location of the docks. Eventually, after riding a rapid succession of waves, the ship maneuvered into the deep water. The initial wave, which had lifted the M/V Chena back toward shore, destroyed what was left of the Valdez waterfront within two blocks of shore; the runup from this wave reached beyond McKinley Street, or about $300 \mathrm{~m}(1,000 \mathrm{ft})$ from the preearthquake shoreline at several points. The second wave crossed the waterfront 10-15 minutes after the first wave, carrying a large amount of the debris. Water from the second wave reached a depth of $0.46 \mathrm{~m}(1.5 \mathrm{ft})$ in the Valdez Hotel on McKinley Street (Wilson and Tørum, 1972).

Shortly after the first and second waves, a tectonic tsunami caused by the seafloor deformation in Prince William Sound and Gulf of Alaska started to approach Port Valdez. After the first 25 minutes, waves reaching Valdez were on the low tide and not high enough to be noticed by the Valdez residents, and could possibly fail to reach a normal hightide level (Wilson and Tørum, 1972). With the tide rising throughout the entire evening, activity of the tectonic waves became more destructive. Most notably the so-called third wave, between 10:30 p.m. and midnight on March 27, and the fourth wave, between 12:30 a.m. and 1:45 a.m. the following morning, flooded the city. Most likely the crests of the third and the fourth wave occurred around 11:45 p.m. and 1:35 a.m., respectively (Wilson and Tørum, 1972). Since the tectonic tsunami became superimposed with the high tide, the third wave reached $0.76 \mathrm{~m}(2.5 \mathrm{ft})$ above ground in the Valdez Hotel on McKinley Street and most likely reached Hobart Street at 11:45 p.m. Water from the fourth wave, nearly coincident with the predicted high tide, was 1.5-1.8 m (5-6 ft) deep in buildings along McKinley Street and $0.6 \mathrm{~m} \mathrm{(2 \textrm {ft } )}$ deep on Hobart Street. Since the final wave left water marks on building exteriors several inches higher than the interior water marks, it was concluded that the final wave advanced and receded with considerable speed. Unfortunately, there are no direct measurements of the water velocity. Finally, we note that although the tectonic waves were smaller in height than the landslide-generated tsunami, they caused widespread flooding and damage.

There were no eyewitnesses to waves that struck the shore at other locations along Port Valdez. However, the inundation line was evident from scattered debris and marks on fresh snow. Figure 5 shows the observed runup around Port Valdez. The highest location obliterated by waves was near the large, abandoned Cliff Mine. According to Plafker and Mayo (1965), the waves deposited driftwood at points $52 \mathrm{~m}$ (170 ft) above sea level and splashed silt and sand up to an elevation of $67 \mathrm{~m}$ (220 ft). Directly across from the Cliff Mine in Anderson Bay at the south shore of Port Valdez, the waves ran up to $24 \mathrm{~m}$ (78 ft) above the water level and destroyed a small fishing camp. All structures of the camp were swept away, leaving only the driven piling foundations. Its sole inhabitant, Harry Henderson, was missing and presumably drowned in the violent local waves that struck Anderson Bay. 


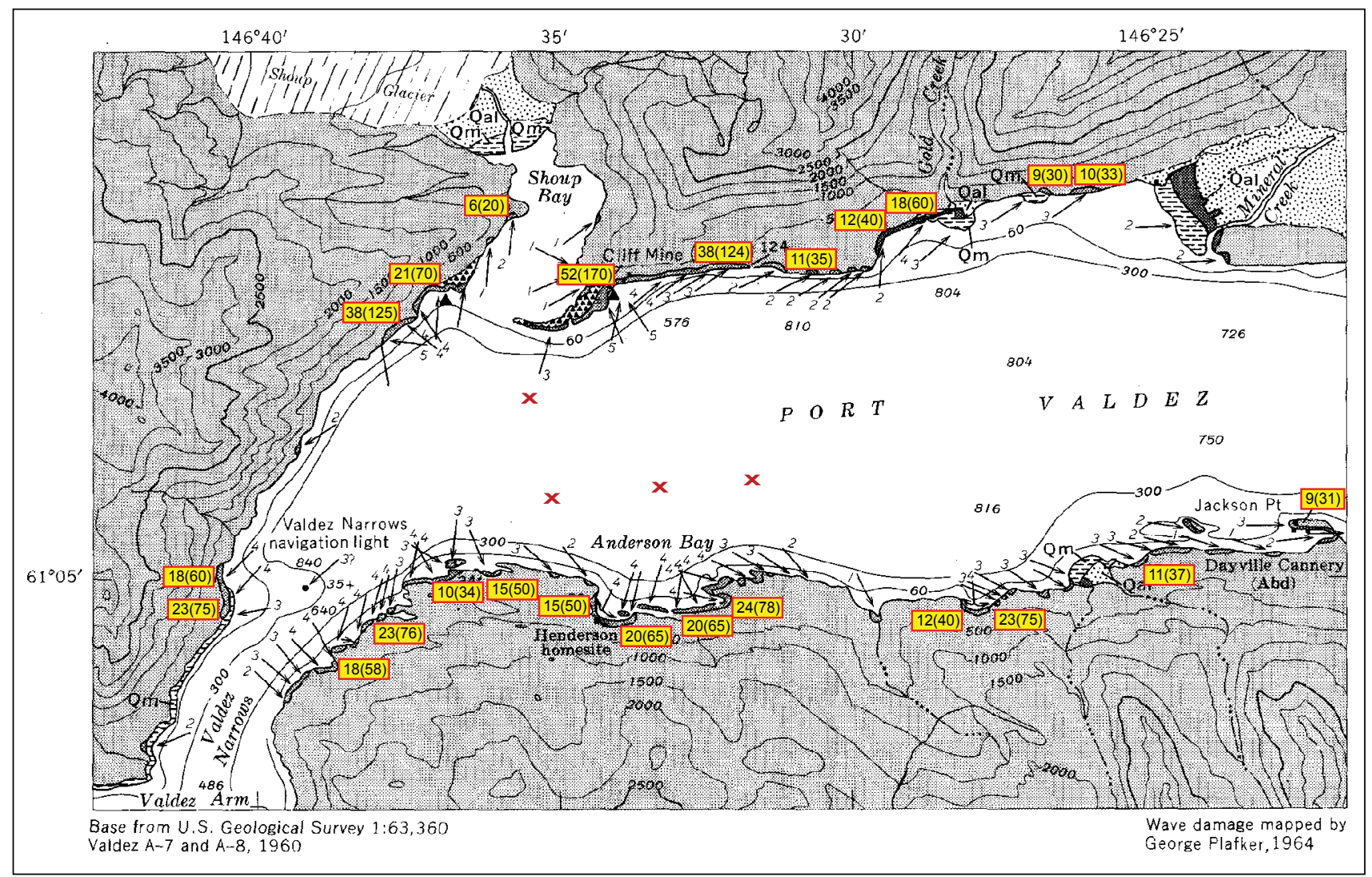

Figure 5. Distribution and intensity of wave damage in Port Valdez after the 1964 earthquake, mapped by L. Mayo and G. Plafker. Inferred direction of the wave arrival is shown by arrows. Relative magnitude of damage is indicated by a numeral at the base of an arrow, based on the scale: 1 -runup about 1-2 $m(0-6 \mathrm{ft}) ; 2$-runup $8 \mathrm{~m}$ (25 ft) on steep shores; 3-maximum runup $17 \mathrm{~m}$ (55 ft); 4-maximum runup $21 \mathrm{~m}$ (70 ft); 5-maximum runup $52 \mathrm{~m}$ (170 ft). Yellow boxed numerals onshore next to shaded areas at edge of water provide runup height in meters (and feet) above sea level at time of the earthquake. The base map and description of the damage are from Plafker and others (1969).

The abandoned Dayville cannery at Jackson Point, $8 \mathrm{~km}$ (5 mi) east of Anderson Bay, was also extensively damaged

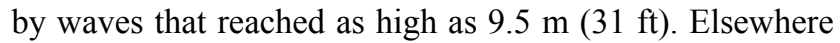
along the shore, violent waves broke spruce trees with a diameter of $0.6 \mathrm{~m}(2 \mathrm{ft})$ at elevations as high as $31 \mathrm{~m}(101 \mathrm{ft})$ and deposited barnacle-covered boulders estimated to weigh 760 $\mathrm{kg}(1,700 \mathrm{lb})$ at points $27 \mathrm{~m}(88 \mathrm{ft})$ above the shoreline. The waves that moved westward from Port Valdez overtopped and destroyed the Valdez Narrows navigation light situated

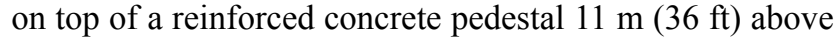
the lower low water level.

Two eyewitnesses to the outgoing wave from Port Valdez - Delbert and 'Red' Ferrier-were in a small boat outside Valdez Narrows near Potato Point, shown in figure 2. They saw waves coming from the direction of Shoup Bay approximately 5 minutes after the earthquake began and watched the first wave overtop and destroy the Valdez Narrows navigation light. Although the wave dissipated rapidly outside Valdez Narrows, the boat barely rode it out without capsizing.
Economic survival of Valdez and of other earthquakedamaged communities heavily depended on financial aid by the federal government (Tanaka, 1973). The landslidegenerated tsunami was responsible for the loss of lives; it completely destroyed the docks and structures on them, the small-boat harbor, and the fishing camp in Anderson Bay; and it damaged dock ramps, buildings at the head of the smallboat harbor, installations in the Standard Oil Co. tank farm, the cannery at Jackson Point, and buildings within two blocks of the waterfront. Figure 6 shows the extent of the tsunami inundation and debris line from the first wave. Following the earthquake, the city was relocated to new land protected by a bedrock ridge and adjacent to the Mineral Creek delta. According to Tanaka (1973), the total funding provided by the federal government for the reconstruction of Valdez was about $\$ 26.5$ million in 1964 dollars $^{6}$. In addition to the federal funding, additional capital was necessary; it is estimated that the cost of reconstructing the city of 750 people was approximately $\$ 50,000$ per person in 1964 dollars. 


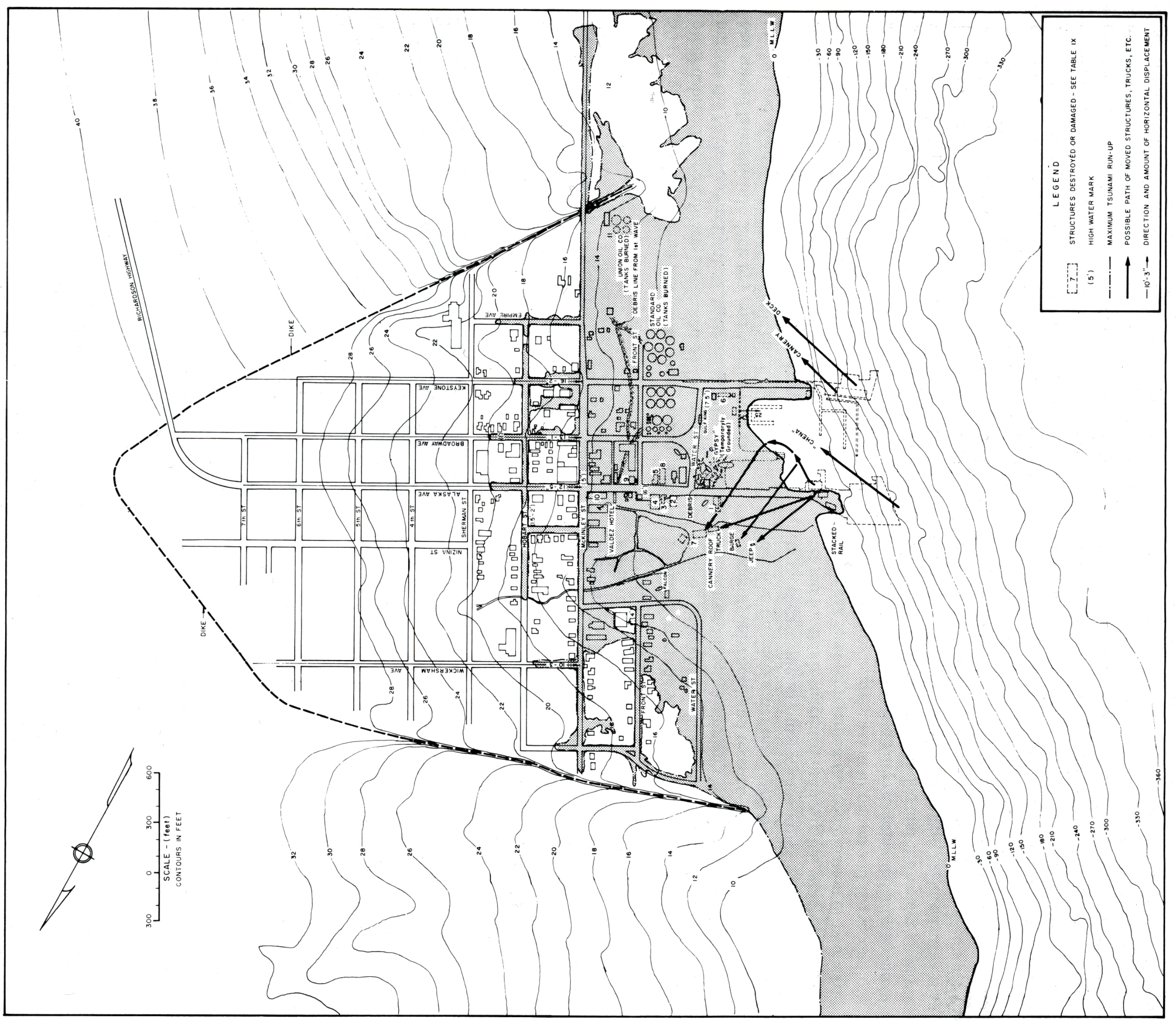





\section{Landslide-Generated Tsunami Hazard in Port Valdez}

Kulikov and others (1998) analyzed tsunami catalog data for the north Pacific coast and showed that south-central and southeastern Alaska have a long recorded history of tsunamis generated by submarine and subaerial landslides, avalanches, and rockfalls. Our review of Valdez's tsunami history supports the conclusion by Kulikov and others (1998). Namely, in the majority of cases, tectonic tsunamis arriving in bays and fjords from the open ocean had wave heights smaller than those of local landslide-generated tsunamis. For example, the 1964 landslide-generated tsunami in Port Valdez devastated the waterfront and caused the $52 \mathrm{~m}(170 \mathrm{ft})$ runup near Shoup Bay, while the tectonic tsunami was not even noticed until a high tide late in the evening? ${ }^{7}$. In this section, we focus on the landslide-generated tsunami hazard in Port Valdez.

Massive underwater slope failures occurred during the 1964 earthquake (Coulter and Migliaccio,1966; Wilson and Tørum, 1972; Ryan and others, 2010). Namely, the failures are identified at the head of Port Valdez and along the Shoup Bay moraine. For the sake of brevity, we label the landslides at these locations by $\mathrm{HPV}_{64}$ and $\mathrm{SBM}_{64}$, respectively. Location of the landslide near the head of Port Valdez during the 1899 earthquake is yet to be identified. Numerous cable breaks occurred at the bottom of Port Valdez shortly after much smaller earthquakes in 1908, 1911, 1912, and 1925. The cable breaks are thought to have been caused by the sediment sliding/gliding along the fjord bottom shortly after the earthquake. When a slide comes to rest, the slide debris forms a deposit, or the so-called debris lobe.

A recent high-resolution ocean-bottom reflection profiling study by Ryan and others (2010) reveals the existence of multiple debris lobes below the present-day bottom in Port Valdez. Figure 6 of Ryan and others (2010) shows at least six lobes in the southwestern part of the bay. The shallowest lobe presumably originated in 1964, while the second lobe is thought to originate 670 to 1,080 years before the 1964 event. Ryan and others (2010) hypothesize that the second lobe is related to a previous massive submarine slope failure during the penultimate earthquake. Carver and Plafker (2008) estimate that the penultimate earthquake occurred 913-808 years B.P., which is in accordance with the age of the discovered second lobe.

A contract paleo-tsunami study by Begét (2007) reveals several sand sheets at onshore sites at the head of Port Valdez, such as near Solomon Gulch and on Saw Island, shown in figure 2 by red stars. Radiocarbon dating of these deposits indicates that the sand sheets appeared at about the same time as the penultimate event. The sand layer at the Solomon Gulch site is traced more than $25 \mathrm{~m}(83 \mathrm{ft})$ inland from the present-day shoreline and $7 \mathrm{~m}(23 \mathrm{ft})$ higher than the current high tide level — an area that the 1964 tsunami did not inundate (Begét, 2007). Thus, the penultimate tsunami could have affected a larger or different area and caused higher or

\footnotetext{
${ }^{7}$ The previous tsunami observations do not ensure future expectations of the wave heights. Both tectonic and landslide-generated tsunamis constitute a serious hazard in glacial fjords such as Port Valdez.
}

different runup distribution in Port Valdez. Begét (2007) was able to find sand horizons in soil pits up to $17 \mathrm{~m}(57 \mathrm{ft})$ above the high tide level, but unfortunately could not date them, and thus could not associate them with any prehistoric event. In addition to the penultimate tsunami layer, Begét found other sandy and silty deposits at the Solomon Gulch site. After the radiocarbon dating was completed, these layers were related to tsunamis 3,800 and 4,300 years B.P., and possibly to a tsunami 5,400 years B.P. The Saw Island site showed only the two prominent layers of the sandy sediments, which were attributed to the penultimate and 1964 events.

Unfortunately, insufficient tsunami recurrence data precludes estimation of future tsunamigenic earthquake and/or landslide-generated tsunamis. Further, little is known about submarine slope failures that occur without being triggered by earthquakes. An example of such an event is a landslide that occurred in Skagway Harbor, Alaska, on November 3, 1994 (Fine and others, 1998; Thomson and others, 2001). The slide and the resulting waves occurred following an extreme low tide (Kulikov and others, 1998). There have also been three distinct incidents when similar slope failures occurred along the Valdez waterfront without any warning (Coulter and Migliaccio, 1966):

\section{$\diamond$ An Early 1920s Event}

A slide occurred when heavy spools of cable were unloaded onto the dock. The following night, a section of the dock bearing the cable collapsed into the ocean and the spools were never found. A piling supporting the dock was not broken, but was carried out by a sliding mass of sediment.

\section{$\diamond$ A Late 1920s Event}

A slide occurred, but was not associated with ground shaking or heavy loads on the dock at the time of failure.

\section{$\diamond$ An Early 1940s Event}

A slide occurred at the cannery dock. Although exact dimensions of the slide are unknown, the entire 30-mlong (100-ft-long) dock was affected. In this occurrence, as in the previous one, there were neither heavy loads nor seismic shaking reported at the time of the incident.

A primary cause of submarine slumps or landslides is the accumulation of sediments on underwater slopes and over-steepening of the deposit. Recent results of sediment chemistry monitoring in Port Valdez demonstrated high sediment accumulation rates of about $15 \mathrm{~mm}$ (0.6 in) per year at the head of Valdez Bay (Savoie and others, 2006).

Lemke (1967), Wilson and Tørum (1968), Plafker and others (1969), and Shannon and Hilts (1973) conducted geologic investigations after the 1964 earthquake in numerous locations around south-central and southeastern Alaska to assess landslide masses. These studies indicate that the major factors contributing to the total volume and aerial extent of the slide material are the duration of ground motion, the configuration of underwater slopes, and the type of sediment forming these slopes - unconsolidated or fine-grained 
materials. Hampton and others (1996) suggest that high artesian pressure in aquifers of the delta, combined with the extra load caused by waterfront artificial fill associated with shoreline development, are also contributing factors to slope failures. Further, Bornhold and others (2001) identify earthquakes, extreme low tides, and construction activities in ports and harbors as the most common triggering mechanisms for underwater slope failures.

Bornhold and others (2001) addressed the problem of estimating the hazard of landslide-generated tsunamis for the British Columbia and Alaska coasts. Such estimation for a coastal community requires assessment of locations of potential underwater failures and the physical parameters of the underwater materials. The most probable locations of unstable sediment accumulations are at the mouths of Valdez Glacier Stream, Lowe River, Mineral Creek, and Gold Creek, as well as locations along the moraine at the head of Shoup Bay (Begét 2007; USGS, P. Haeussler, written commun., 2011). Bornhold and others (2001) outlined specific features for long-term prediction of landslide-generated tsunamis at selected sites, and developed a long-term approach for estimating potential tsunami inundation. The approach consists of two steps. First, it is necessary to analyze historical events and compare modeling results with observations at the physical site and second, simulate hypothetical tsunami scenarios. We follow Bornhold and others (2001) and employ their methodology to estimate the local tsunami hazard in Port Valdez.

\section{METHODOLOGY AND DATA}

\section{Grid Development and Data Sources}

One of the challenges in tsunami modeling is that the governing equations for water dynamics are continuous. In this work, we discretize the shallow-water equations in spherical coordinates on Arakawa C-grid using a finite difference method. To resolve a wave, the grid must be fine enough, with at least four points per wavelength (Titov and Synolakis, 1995); however, more points than that are often necessary to achieve satisfactory accuracy (for example, Titov and Synolakis, 1997). To compute a detailed map of potential tsunami inundation triggered by local and distant earthquakes, we employ a series of nested computational grids. A nested grid allows for higher resolution in areas where it is needed, without expending computer resources in areas where it is not. The bathymetric and topographic relief in each nested grid is based on digital elevation models (DEMs) developed at the National Geophysical Data Center (NGDC), National Oceanic \& Atmospheric Administration (NOAA), in Boulder, Colorado. The extent of each grid used for Valdez mapping is shown in figure 7 and listed in table 1. The coarsest grid, whose resolution is 2-arc-minute, or approximately $2 \mathrm{~km}(1.24 \mathrm{mi})$, spans the central and northern Pacific Ocean, while the highest resolution grid covers Port Valdez, including Anderson Bay and a part of Shoup Bay. The spatial resolution of the high-resolution grid, with

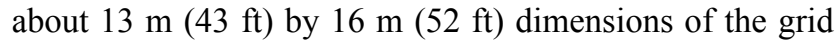
cell, satisfies NOAA minimum recommended requirements for computation of tsunami inundation (National Tsunami Hazard Mapping Program [NTHMP], 2010).

The bathymetry data for the 2-arc-minute resolution grid, whose extent is shown in figure 7, is extracted from the ETOPO2 data set (NOAA, National Geophysical Data Center). To develop 8/3-, 8- and 24- arc-second resolution grids, shoreline, bathymetric, and topographic digital datasets were obtained from several U.S. federal and academic agencies, including NOAA's National Ocean Service (NOS), Office of Coast Survey, and NGDC; the U.S. Fish and Wildlife Service (FWS); the U.S. Geological Survey (USGS); and the U.S. Army Corps of Engineers (USACE). All data were shifted to World Geodetic System 1984 (WGS 84) horizontal and Mean Higher High Water (MHHW) vertical datums. The FWS statewide Alaska digital coastline was employed to create a coastline of the Prince William Sound region. Bathymetric datasets used in the compilation of the Prince William Sound DEMs included NOS hydrographic surveys, a recent USACE harbor survey, NOAA Electronic Navigational Charts, multibeam swath sonar surveys, and NGDC trackline surveys. Topographic datasets of Prince William Sound were obtained from the USGS National Elevation Dataset 2-arc-second gridded topography and 1-arc-second NASA Space Shuttle Radar Topography. The data sources and methodology used

Table 1. Fault parameters for the Yakataga-Yakutat (YY) segment

\begin{tabular}{|c|c|c|c|c|c|c|c|c|}
\hline $\begin{array}{c}\text { Latitude } \\
(\text { deg. N) }\end{array}$ & $\begin{array}{c}\text { Longitude } \\
(\mathbf{d e g} . \mathbf{W})\end{array}$ & $\begin{array}{c}\text { Depth } \\
(\mathbf{k m})\end{array}$ & $\begin{array}{c}\text { Length } \\
(\mathbf{k m})\end{array}$ & $\begin{array}{c}\text { Width } \\
(\mathbf{k m})\end{array}$ & $\begin{array}{c}\text { Strike } \\
(\mathbf{d e g})\end{array}$ & $\begin{array}{c}\text { Dip } \\
(\mathbf{d e g} .)\end{array}$ & $\begin{array}{c}\text { Rake } \\
(\mathbf{d e g} .)\end{array}$ & $\begin{array}{c}\text { Slip } \\
(\mathbf{m})\end{array}$ \\
\hline 59.17 & 144.12 & 1 & 50.1 & 190 & 256 & 12 & 90 & 15 \\
\hline 59.36 & 143.23 & 3 & 51.1 & 141 & 250.4 & 10 & 90 & 15 \\
\hline 59.54 & 142.42 & 5 & 47.8 & 114.8 & 245.8 & 6 & 90 & 15 \\
\hline 59.94 & 141.21 & 5 & 79.7 & 99.6 & 237.8 & 8 & 90 & 15 \\
\hline
\end{tabular}

Figure 7 (right). Nesting of the bathymetry/topography grids for numerical modeling of tsunami propagation and runup. The coarsest grid, Level 0, covers the central and northern Pacific Ocean. Location of each embedded grid is marked by a red rectangle. No map is provided of the high-resolution grid, Level 4, as this grid does not nest any other grids. The red semi-transparent rectangles mark areas of the grid refinement. 


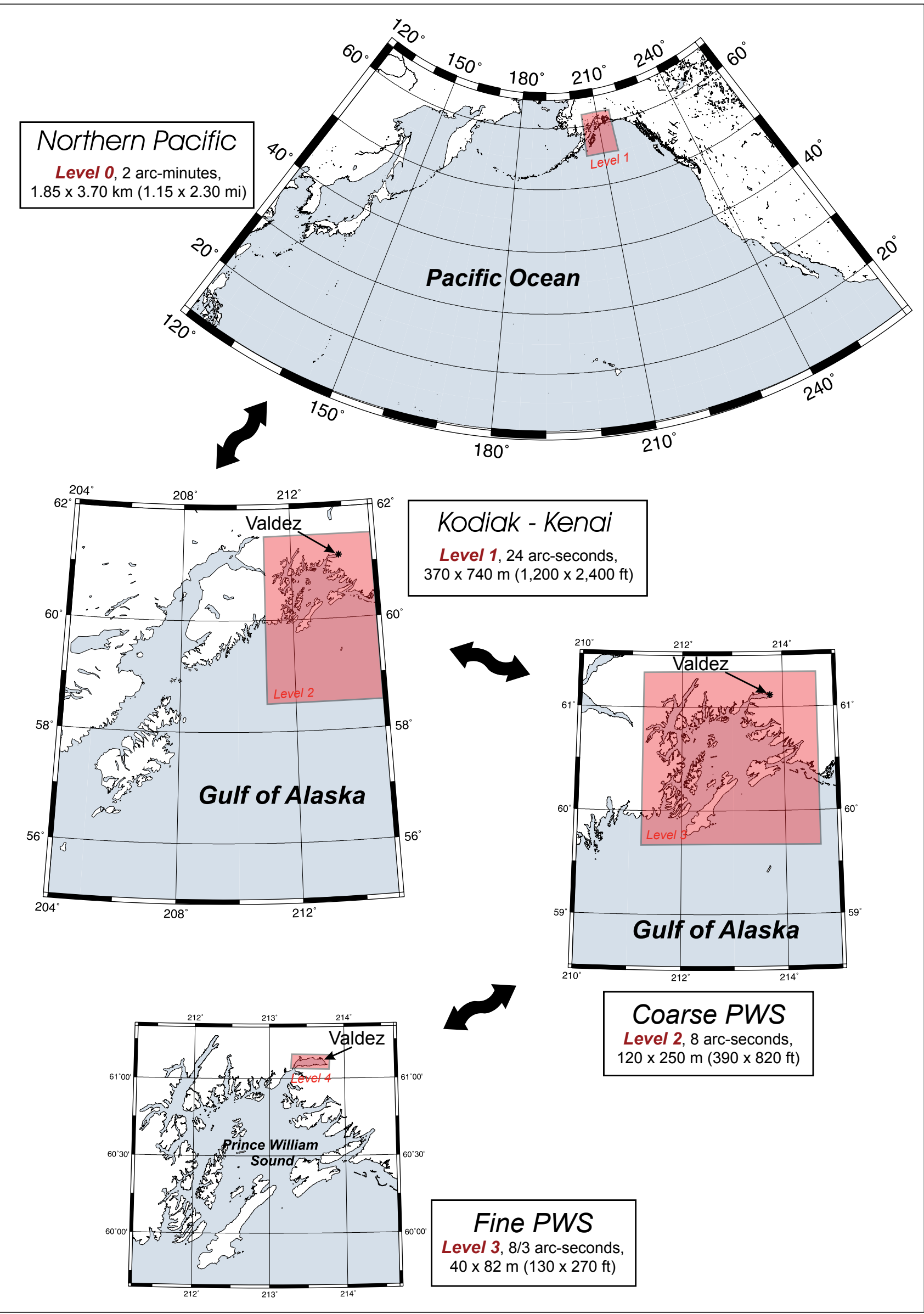


to develop high-resolution, 8/3-, 8-, and 24-arc-second DEMs are described in great detail by Caldwell and others (2009); Lim and others (2009).

The high-resolution DEM is developed by K. Labay and P. Haeussler at the USGS Alaska Science Center in Anchorage by combining NOS multibeam bathymetric surveys H11180, H11181, and H11182; and Aero Metric's highaltitude and low-altitude "bare earth" Light Detection and Ranging (LiDAR) surveys. Intertidal depths were developed by digitizing shorelines at known tide stages from Landsat images provided by Geographic Information Network of Alaska (GINA).

First, the bathymetry surveys in the mean lower low water (MLLW) vertical datum were used to populate the high-resolution DEM (an ArcGIS raster grid) covering Port Valdez and coastal areas. Note that at this step the topography is not yet defined in the DEM. The survey depths were then adjusted to the mean high water (MHW) vertical datum by adding $3.4 \mathrm{~m}(11.2 \mathrm{ft})$ (datums by NOAA, http://tidesandcurrents.noaa.gov/). Second, high and low altitude LiDAR data points were merged to create a 4-m- (13-ft-) resolution ArcGIS raster grid. The vertical datum in this grid was then transformed to MHW from NAVD88 by subtracting $3.2 \mathrm{~m}$ $(10.5 \mathrm{ft})$, which includes the difference of $0.26 \mathrm{~m}(0.85 \mathrm{ft})$ between NAVD88 and MLLW at Valdez. Third, the topography data from the 4-m- (13-ft-) resolution grid was interpolated into the high-resolution DEM by using a bilinear algorithm.

Analysis of the combined bathymetry and topography data in the high-resolution DEM revealed a region with missing data in an intertidal zone, parts of which were not covered by either the multibeam surveys or the LiDAR survey. To fill in the missing data region, Landsat images of the intertidal zone were acquired. Elevations for some parts of this region were defined using the historic tide data at the time of image acquisition as follows. If the time was given, NOAA's Tides and Currents website was used to find an exact height of the tide, hence allowing us to define an isobath in the intertidal zone. If the time was not given, the azimuth and angle of the sun was used to find the image time from the sun azimuth/ altitude tables provided by the Naval Oceanography Portal (http://aa.usno.navy.mil/data/docs/AltAz.php). The points in Valdez harbor are set to a constant depth of $7.5 \mathrm{~m}(24.6 \mathrm{ft})$. Once the isobaths in the intertidal zone were defined, an auxiliary grid was created by merging all data points using the ArcGIS 'natural neighbor' interpolation tool. The auxiliary grid was then used to fill gaps between the previously created LiDAR and multibeam datasets to make the final seamless bathymetry/topography grid. Finally the high-resolution DEM, Level 4, was adjusted to the MHHW datum by D. West at the Geophysical Institute, UAF.

\section{Development of the Pre- and Post-Earthquake Bathymetry and the 1964 Slide Configuration}

Numerical modeling of the 1964 landslide-generated and tectonic tsunamis in Port Valdez required development of a high-resolution DEM of the study area shortly after the earthquake. This DEM is referred to as $\mathrm{DEM}_{64}$ and its construction is outlined in this section.

We utilized a combination of the pre- and post-earthquake bathymetry/topography data. The bathymetry in the eastern part of Port Valdez is provided by Hydrographic Survey H08493, conducted in 1959, and two surveys, H08899 and H08900, completed in 1966. Additional bathymetry data near the old town can be found in Coulter and Migliaccio (1966, plate 2). On the basis of 1959 and 1966 bathymetry and the post-earthquake topography in the old town shown in figure 6 , we reconstructed slide configurations $\mathrm{HPV}_{64}$ and $\mathrm{SBM}_{64}$ for the areas' bathymetry during the 1964 event.

First, we digitized the post-earthquake topographic/bathymetric contours as well as the extent of the inundation from a plan of Valdez shown in figure 6 . The digitized topography contours were supplemented by the post-earthquake ground elevation profile along Alaska Avenue between Waterfront Street and Hobart Street (Coulter and Migliaccio, 1966, plate 1). Similar ground subsidence was inferred to have occurred along adjacent Nizina Street and Keystone Avenue. After georeferencing and interpolating all digitized data, we constructed a post-earthquake Old Valdez Harbor DEM covering a region from $60 \mathrm{~m}(200 \mathrm{ft})$ depth off the Old Valdez Harbor to $8.4 \mathrm{~m}$ (28 ft) above the MLLW level, approximately at Sherman Street. The constructed Old Valdez Harbor DEM does not cover the region where sediments are currently deposited by the Lowe River and Valdez Glacier Stream. Therefore, prior to incorporating the Old Valdez Harbor DEM into the present-day DEM (Level 4), we digitally removed the post-1964 sediment accumulation from the present-day DEM. Note that while transforming the DEMs, we took into account the consistent vertical datum corrections.

To estimate the post-1964 sediment accumulation, we computed the difference between the post-earthquake bathymetry (based on NOS H08899 and H08900 in 1966) and the present-day bathymetry (based on NOS H11180, H11181, and H11182 in 2003). The bathymetry difference revealed that the volume of sediment accumulation at the Lowe River and Valdez Glacier Stream mouth deltas was about 8 million $\mathrm{m}^{3}\left(10.5\right.$ million $\left.\mathrm{yd}^{3}\right)$ in the 37 years between 1966 and 2003. The maximum thickness of the accumulation is about $50 \mathrm{~m}(165 \mathrm{ft})$. We then digitally removed the sediment accumulation from the present-day high-resolution DEM, and obtained an approximation of the post-earthquake DEM. We emphasize that this approximation is a seamless DEM with present-day topography and post-earthquake bathymetry. Finally, the approximation was improved by replacing the present-day elevation near the old townsite with data from the post-earthquake Old Valdez Harbor DEM.

By computing the difference between the pre-earthquake bathymetry (based on NOS H08493 in 1959, courtesy of K. Labay and P. Haeussler, who provided the pre-earthquake DEM) and the $\mathrm{DEM}_{64}$, we determined the geometry of the $\mathrm{HPV}_{64}$ and $\mathrm{SBM}_{64}$ slides. Because the pre-earthquake survey $\mathrm{H} 08493$ covers only the vicinity of the old harbor, there are large uncertainties in the estimations of the landslide thickness and its geometry south of the Old Valdez Harbor at the head of the port and in deep water away from the shoreline. 
Our computations show that approximately 55 million $\mathrm{m}^{3}$ $\left(72\right.$ million $\left.\mathrm{yd}^{3}\right)$ of sediment slid into the port between the old harbor and the present-day Lowe River mouth delta. In addition to the $\mathrm{HPV}_{64}$ slide volume, we find that the $\mathrm{SBM}_{64}$ slide volume was approximately 255 million $\mathrm{m}^{3}$ (333 million $\left.\mathrm{yd}^{3}\right)$. The reconstructed thickness of the $\mathrm{SBM}_{64}$ and $\mathrm{HPV}_{64}$ slides are displayed in figures $8 \mathrm{a}$ and $8 \mathrm{~b}$,respectively. The MLLW shorelines before and after the earthquake are also plotted on figure 8, shown as red and yellow dashed lines, respectively.

According to Coulter and Migliaccio (1966), approximately 75 million $\mathrm{m}^{3}\left(98\right.$ million $\left.\mathrm{yd}^{3}\right)$ of the sediment underlying the old townsite failed and slipped into the port. At the same time, the total volume of all slides during the 1964 event was estimated by Ryan and others (2010) to be close to 1,000 million $\mathrm{m}^{3}\left(1,300\right.$ million $\left.\mathrm{yd}^{3}\right)$, several times higher than our estimates. We emphasize that our reconstructions of the 1964 slides are approximations of the initial material that failed in the 1964 event. Lee and others (2007) suggested that some material was scraped off the bay walls and seafloor and was likely incorporated into the slide along its path. This may partially explain the difference between the initial volume and much larger total volume of the slide deposit. Additionally, it is probable that some of sediment transfer took place before the earthquake, between 1959 and 1964, and that additional material was carried down after the landslide event during a slope readjustment process (Coulter and Migliaccio, 1966). These two physical processes have contributed to the much larger total slide volume estimated by Ryan and others (2010).

\section{Numerical Model of Tsunami Propagation and Runup}

NOAA recently published a technical memorandum that outlines major requirements for numerical models used in inundation mapping and tsunami forecasting, and describes a procedure for model evaluation (Synolakis and others, 2007; National Tsunami Hazards Mapping Program [NTHMP], 2012). There are two major components to this process. The first, model validation, ensures that the model correctly solves appropriate equations of motion by comparing model results with known solutions; this is achieved through analytical and laboratory benchmarking. The second component is model verification, or testing the model, using observations of real events through field data benchmarking.

The numerical model currently used by the Alaska Earthquake Information Center (AEIC) for tsunami inundation mapping has been validated through a set of analytical benchmarks and tested against laboratory and field data (Nicolsky and others, 2011a; Nicolsky, 2012). The model solves nonlinear shallow-water equations using a finite-difference method on a staggered grid. For any coarse-fine pair of computational grids, we apply a time-explicit numerical scheme as follows. First, we compute the water flux within a coarse-resolution grid. These calculated flux values are used to define the water flux on a boundary of the fine-resolution grid. Next, the water level and then the water flux are calculated over the fine-resolution grid. Finally, the water level computed in the fine-resolution grid is used to define the water level in the area of the coarse-resolution grid that coincides with the fine grid. Consecutively, we compute the water elevation for all other points in the coarse grid and proceed to the next time step. More details about the numerical scheme, grid nesting and time stepping can be found in (Goto and others, 1997; Nicolsky and others, 2011a). Despite the fact that nested grids decrease the total number of grid cells needed to preserve computational accuracy in certain regions of interest, actual simulations are still unrealistic if parallel computing is not implemented. Here, we use the Portable Extensible Toolkit for Scientific computation (PETSc), which provides sets of tools for the parallel numerical solution of shallow-water equations. In particular, each computational grid listed in table 2 can be subdivided among an arbitrary number of processors. The above-mentioned passing of information between the water flux and level is implemented efficiently using PETSc subroutines.

We assess hazards related to tectonic and landslidegenerated tsunamis in Port Valdez by performing model simulations for each hypothetical earthquake and landslide source scenario. To simulate tsunami dynamics caused by a seafloor deformation due to an earthquake, we assume some simplifications. First, an initial displacement of the ocean surface is equal to the vertical displacement of the ocean floor induced by the earthquake rupture process. Second, the finite speed of the rupture propagation along the fault is not

Table 2. Nested grids used to compute propagation of tsunamis generated in the Gulf of Alaska to the city of Valdez. The high-resolution grid is used to compute the inundation. Note that the grid resolution in meters is not uniform and is used to illustrate grid fineness near Valdez. The first dimension is the longitudinal grid resolution, while the second is the latitudinal grid resolution.

\begin{tabular}{|c|c|c|c|c|}
\hline \multirow[b]{2}{*}{ Grid name } & \multicolumn{2}{|c|}{ Resolution } & \multirow{2}{*}{$\begin{array}{l}\text { West-East } \\
\text { boundaries }\end{array}$} & \multirow{2}{*}{$\begin{array}{l}\text { South-North } \\
\text { boundaries }\end{array}$} \\
\hline & arc-seconds & $\begin{array}{c}\text { meters (at } \\
\text { Valdez) }\end{array}$ & & \\
\hline Level 0, Northern Pacific & $120 \times 120$ & $\approx 1,850 \times 3,700$ & $120^{\circ} 00^{\prime} \mathrm{E}-100^{\circ} 00^{\prime} \mathrm{W}$ & $10^{\circ} 00^{\prime} \mathrm{N}-65^{\circ} 00^{\prime} \mathrm{N}$ \\
\hline Level 1, Kodiak-Kenai & $24 \times 24$ & $\approx 370 \times 740$ & $145^{\circ} 00^{\prime} \mathrm{W}-156^{\circ} 00^{\prime} \mathrm{W}$ & $55^{\circ} 00^{\prime} \mathrm{N}-62^{\circ} 00^{\prime} \mathrm{N}$ \\
\hline Level 2, Coarse PWS & $8 \times 8$ & $\approx 120 \times 250$ & $145^{\circ} 00^{\prime} \mathrm{W}-150^{\circ} 00^{\prime} \mathrm{W}$ & $58^{\circ} 30^{\prime} \mathrm{N}-61^{\circ} 30^{\prime} \mathrm{N}$ \\
\hline Level 3, Fine PWS & $8 / 3 \times 8 / 3$ & $\approx 40 \times 82$ & $145^{\circ} 20^{\prime} \mathrm{W}-148^{\circ} 46^{\prime} \mathrm{W}$ & $59^{\circ} 40^{\prime} \mathrm{N}-61^{\circ} 20^{\prime} \mathrm{N}$ \\
\hline Level 4, High resolution & $8 / 9 \times 8 / 15$ & $\approx 13 \times 16$ & $146^{\circ} 43^{\prime} \mathrm{W}-146^{\circ} 09^{\prime} \mathrm{W}$ & $61^{\circ} 04^{\prime} \mathrm{N}-61^{\circ} 09^{\prime} \mathrm{N}$ \\
\hline
\end{tabular}




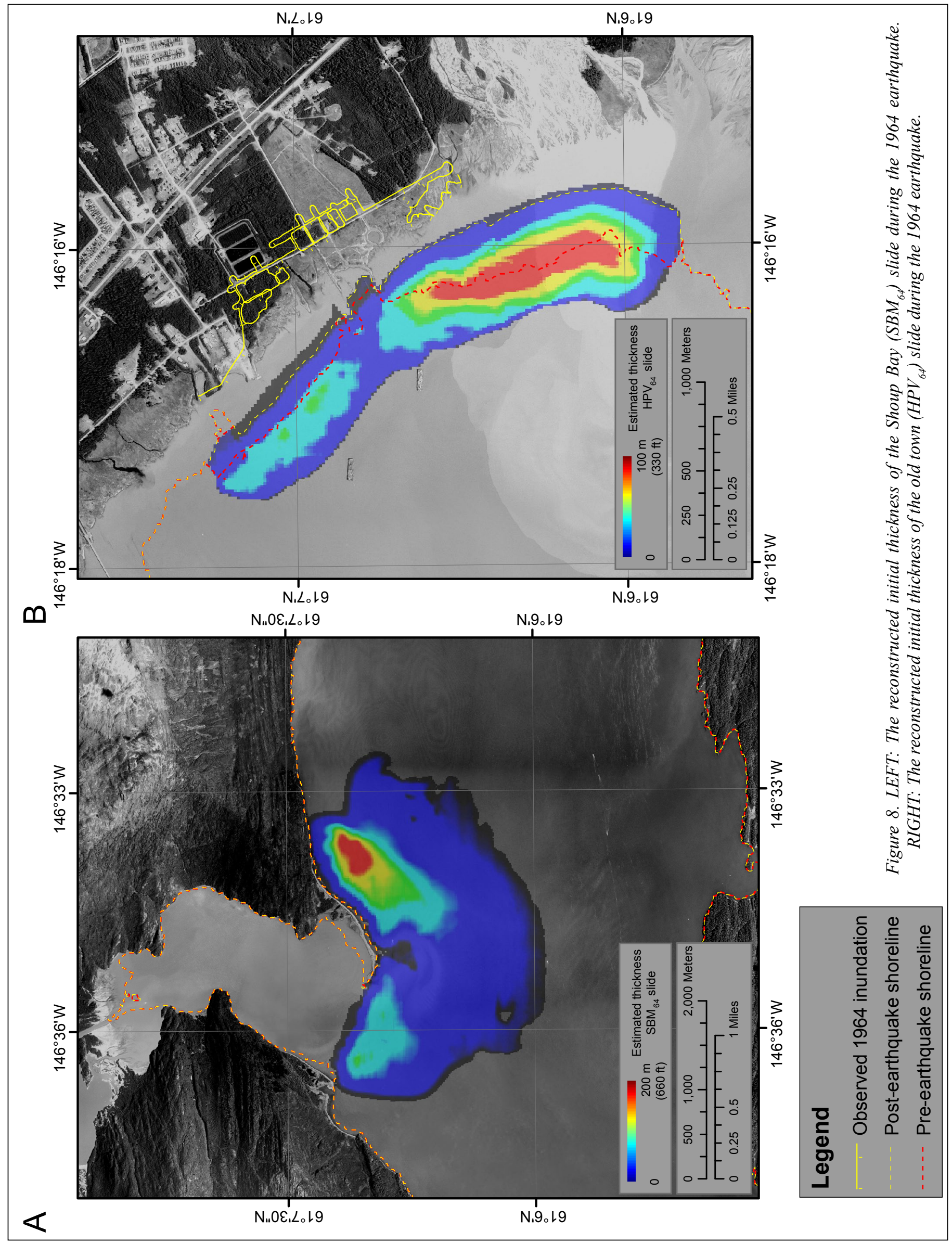


taken into account. We consider the ocean bottom displacement to be instantaneous. Third, the initial topography is modified to account for coseismic deformation of land due to the earthquake.

At the end of a tsunami simulation, each of the grid points has either a value of 0 if no inundation occurs or 1 if seawater reaches the grid point at any time. The inundation line lies halfway between grid points with values of 0 and 1 , but was adjusted visually to accommodate obstacles or local variations in topography not represented by the DEM. Although the developed algorithm has passed through the rigorous benchmarking procedures (Nicolsky and others, 2011a; Nicolsky, 2012), there is still an uncertainty in locating an inundation line. However, this uncertainty is to a greater degree unknown because the inundation line is the result of a complex modeling process. Affecting the accuracy of the inundation line are many factors on which the model depends, including suitability of the earthquake source model, accuracy of the bathymetric and topographic data, and the adequacy of the numerical model in representing the generation, propagation, and runup of tsunamis. In this report, we do not attempt to adjust the modeled inundation limits to account for these uncertainty factors.

Note that the model has several limitations. One important limitation is that the model does not take into account the periodic change of sea level due to tides. We conducted all model runs using bathymetric data that correspond to the MHHW tide level in Port Valdez, with the exception of numerical modeling of the 1964 tsunami for the purpose of model validation.

\section{Numerical Model of Landslide-Generated Tsunamis}

To simulate tsunamis produced by multiple underwater slope failures in Port Valdez on March 27, 1964, we use a numerical model with two components: A viscous underwater slide component and a non-linear shallow-water component. The model assumes full coupling between the deforming slide and the water waves that it generates. The coupling of these two components was initially proposed by Jiang and LeBlond (1992). The model assumptions and its applicability for simulating underwater mudflows are discussed by Jiang and LeBlond $(1992 ; 1994)$ in their formulation of the viscous slide model. Fine and others (1998) improved the coupled model by including realistic bathymetry, and by correcting errors in the governing equations. The non-linear shallowwater component of the coupled model is identical to the tectonic tsunami model except for some auxiliary source terms, and hence the runup of ocean waves described by the water component of the coupled model is verified according to Synolakis and others (2007) and NTHMP (2012). The viscous underwater slide component was successfully used to simulate landslide-generated tsunami, for example, in Seward and Whittier (Suleimani and others, 2010; Nicolsky and others, 2011b). Benchmarking procedures for numerical models describing a deformable slide and its coupling with water waves are yet to be developed.
The coupled model uses non-linear shallow-water approximation for water waves and the deforming slide, which means that the wavelength is much greater than the local water depth, and the slide thickness is much smaller than the characteristic length of the slide along the slope (Jiang and LeBlond, 1994). Assier-Rzadkiewicz and others (1997) argued that the long-wave approximation could be inaccurate for slopes exceeding 10 degrees. Rabinovich and others (2003) studied the validity of the long-wave approximation for slopes greater than 10 degrees and found that for a slope of 16 degrees, the possible error in the gravitational forcing was 8 percent, and for the maximum slope in their study of 23 degrees, the possible error was 15 percent. Because the average pre-earthquake offshore slopes range from 10 to 30 degrees in Port Valdez, the possible error could be higher. Generation of the water gravity waves strongly depends on the relative speeds of the gravity wave and the slide front. Resonance occurs when the speed of the slide front is equal to the local long-wave speed (Rabinovich and others, 2003). Further scientific studies are necessary to estimate how an error in the slide forcing manifests itself in the modeled wave height errors for Port Valdez.

The advantage of the vertically integrated model by Jiang and LeBlond (1992) is its ability to simulate runup of real landslide tsunami events using high-resolution numerical grids. Although model runs require the use of high-performance computing, the computational times are reasonable. This model was successfully applied to simulate a tsunami event in Skagway Harbor, one of numerous fjords in southeastern Alaska, where tsunamis were generated by a submarine landslide on November 3, 1994 (Fine and others, 1998; Thomson and others, 2001). The results of numerical simulations were in good agreement with the tide gauge record in Skagway Harbor. Rabinovich and others (2003) simulated potential underwater landslides in British Columbia fjords, with settings similar to Port Valdez, and demonstrated that this model can also be used for tsunami hazard assessment.

\section{TSUNAMI SOURCES}

One of the most destructive tectonic tsunamis in Alaska history was triggered by the 1964 Great Alaska Earthquake that ruptured a region from Prince William Sound to Kodiak Island. Before discussing this earthquake as well as other credible scenarios for potential tsunamigenic earthquakes, we review some aspects of the regional plate tectonics.

\section{Regional Seismotectonics}

According to the segmentation model of Nishenko and Jacob (1990), south-central Alaska includes three segments of the megathrust: Yakataga-Yakutat (YY), Prince William Sound (PWS), and Kodiak Island (KI) segments, all shown in figure 9. Using seismic waveform data, Christensen and Beck (1994) show that there were two areas of high moment release, representing the two major asperities of the 1964 rupture zone: The Prince William Sound asperity with an average slip of $18 \mathrm{~m}(59 \mathrm{ft})$, and the Kodiak asperity with an 


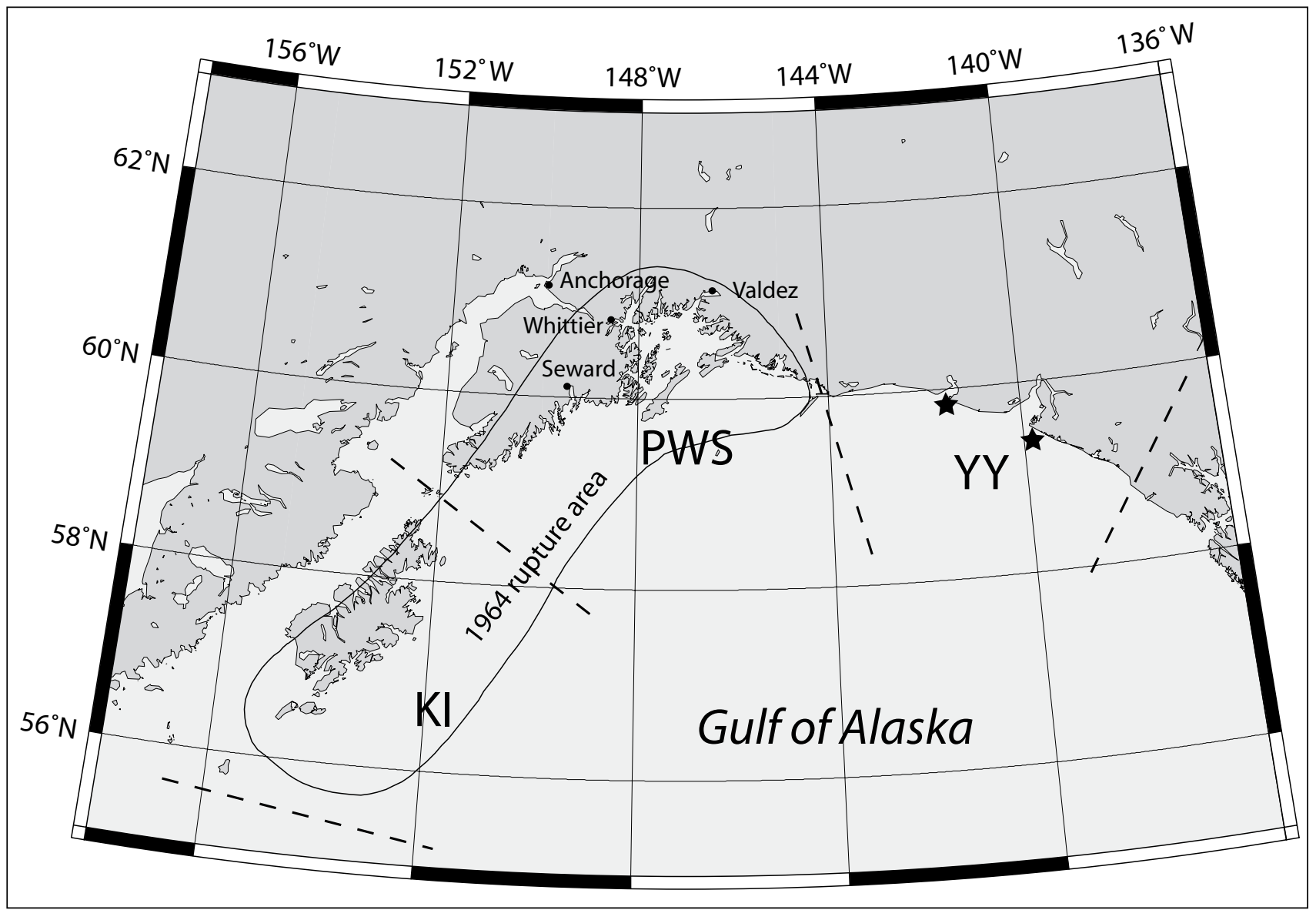

Figure 9. Map of south-central Alaska, showing the rupture zone of the 1964 Great Alaska Earthquake and divisions of the Alaska-Aleutian megathrust: Prince William Sound (PWS), Kodiak Island (KI) and Yakataga-Yakutat (YY) segments. Stars indicate epicenters of two earthquakes of September 1899.

average slip of $10 \mathrm{~m}(33 \mathrm{ft})$. Analysis of historical earthquake data in PWS and KI segments (Nishenko and Jacob, 1990) showed that the KI segment produced significant megathrust earthquakes more frequently and also independently of the PWS segment. Paleoseismic data also show that the KI segment ruptured independently in a large earthquake about 500 years ago, about 360 years more recently than the penultimate great earthquake that ruptured both the KI and PWS segments (Carver and Plafker, 2008).

The results of joint inversion of tsunami and geodetic data from the 1964 earthquake (Johnson and others, 1996) also suggest the division of the rupture zone into two different segments. These segments have different recurrence intervals, with estimates of the recurrence interval for $M_{S} 7.5-8$ earthquakes in the KI segment being as low as 60 years (Nishenko, 1991 [as cited in Johnson and others, 1996]). On the basis of all published paleoseismic data for the region, Carver and Plafker (2008) calculated that the median intervals among the past eight great earthquakes in the PWS segment of the eastern Aleutian seismic zone range from 333 to 875 years, and average 589 years.

The Yakataga-Yakutat area at the eastern end of the megathrust is a complex collision zone where the Yakutat microplate moves northwest toward central Alaska at $48 \mathrm{~mm}$ (1.9 in) per year (Carver and Plafker, 2008). This segment translates the predominantly strike-slip motion on its eastern side to shallow-dipping subduction on its west side (Nishenko and Jacob, 1990). The southern and eastern boundaries of the Yakutat block are well defined, but a collection of distributed fold and thrust zones, splay faults, and mountain-building regions complicates the northern and western edges of the block. We note that the interaction between the Yakutat block and the Pacific and North American plates is complex and poorly understood. Plafker and Thatcher (2008) re-evaluated the mechanisms of the two great Yakutat Bay earthquakes of September 1899 and showed that coseismic deformation was onshore uplift, explaining the absence of a tsunami in the Gulf of Alaska. Plafker and Thatcher (2008) conclude that the 1899 earthquake sequence most likely did not rupture through the offshore portion of the Yakataga seismic gap, a region between the 1964 rupture area and the focal area of the 1899 earthquakes. This finding suggests that the YY segment has a high potential for a future tsunamigenic earthquake.

In a paleoseismic study of regional land subsidence at Kenai Peninsula sites, Hamilton and Shennan (2005) estimated coseismic subsidence during the 1964 earthquake and two earlier events. It was shown that the earthquake dated to 1,500-1,400 years B.P. produced more than twice the subsidence caused by the 1964 earthquake. By comparing the Kenai Peninsula sites with other sites around Cook Inlet, 
the authors find that each of the three great earthquakes in the study had a different pattern of coseismic subsidence. Recent work by Shennan and others (2008) tests the hypothesis that in some seismic cycles, megathrust segments can, as proposed in the segmentation model by Nishenko and Jacob (1990), rupture simultaneously to produce earthquakes of greater magnitude than historical events. Shennan and others (2008) present geologic evidence of six prehistoric major tsunamigenic earthquakes in the Kenai Peninsula area of south-central Alaska in the past 4,000 years based on radiocarbon ages of tidal marsh deposits in Girdwood. Their paper presents paleoseismic evidence that earthquakes approximately 900 and 1,500 years B.P. simultaneously ruptured three adjacent segments of the Aleutian megathrust: The PWS and KI segments, and the Yakutat microplate (the YY segment). The rupture area of these earthquakes was estimated to be $23,000 \mathrm{~km}^{2}\left(8,880 \mathrm{mi}^{2}\right)$ greater than that of the $M_{w} 9.2$ Great Alaska Earthquake of 1964, and with a 15 percent larger seismic moment. This demonstrates that an understanding of the most recent great earthquakes in the area is insufficient for comprehensive tsunami hazard assessment in south-central Alaska, and that detailed studies of multiple great earthquakes are required. In the remainder of this section, we develop several hypothetical tsunamigenic earthquake models and describe them. For each model we perform a numerical modeling experiment to estimate impact of the tsunamis on Valdez.

\section{Tectonic Tsunami Sources}

The 1964 Great Alaska Earthquake ruptured the PWS and KI segments simultaneously (Christensen and Beck, 1994). Shennan and others (2009) present geologic evidence that the PWS and KI segments as well as a portion of the Yakutat microplate have ruptured simultaneously in the past. Therefore, we consider hypothetical tsunamigenic earthquakes produced by various combinations of the PWS, KI, and YY segment ruptures, some occurring simultaneously. In addition, it is worth considering a rupture of the Cascadia subduction zone, involving the Juan de Fuca Plate underlying the Pacific Ocean from mid-Vancouver Island in British Columbia, southwest Canada, along the Pacific Northwest coast.

\section{Models of the 1964 Great Alaska Earthquake}

The 1964 tectonic tsunami affected numerous communities along the Pacific Northwest coast, Hawaii, and Alaska. This tsunami was studied in depth by several investigators (Plafker, 1967; Wilson and Tørum, 1968; Lemke, 1967). Plafker (1967) gives a detailed description of the motion observed on the Patton Bay fault during the Great Alaska Earthquake of 1964, and provides a full report of the surface rupture and fault motion, as well as several pieces of evidence suggesting that the fault continues on the ocean floor well past the region where it is currently mapped. Holdahl and Sauber (1994) applied Plafker's description to construct their model of the Patton Bay fault, which was used in an inversion of geodetic data. Johnson and others (1996) used the results of Holdahl and Sauber (1994) to augment their joint inversion of geodetic and tsunami data and to further reconstruct coseismic deformation models of the 1964 earthquake.

In this study, we use two coseismic deformation models of the 1964 earthquake - the Johnson and others (1996) and the Suito and Freymueller (2009) models - to generate the vertical displacements of the sea floor during the earthquake. We hereafter reference Johnson and others (1996) as the Johnson deformation model (JDM) and Suito and Freymueller (2009) as the Suito deformation model (SDM).

Johnson and others (1996) derived a detailed slip distribution for the 1964 earthquake, which has eight subfaults representing the KI asperity and nine subfaults in the PWS asperity. One subfault was assigned to represent the Patton Bay fault. Johnson and others (1996) and Holdahl and Sauber (1994) used only the mapped extent of the fault, approximately $72 \mathrm{~km}$ (45 mi), despite evidence suggesting that the fault may extend much farther to the southwest. For example, Suito and Freymueller (2009) found that they could not fit all the GPS data accurately unless they extended the fault past the tip of the Kenai Peninsula. In the same report, Suito and Freymueller (2009) developed a coseismic deformation model of the 1964 earthquake based on a three-dimensional (3-D) viscoelastic model, which implements a realistic geometry with an elastic slab having low dip angle. This coseismic model is not based on an inversion, but it resembles a recently published inversion model (Ichinose and others, 2007) as well as some previously proposed models (Holdahl and Sauber, 1994; Johnson and others, 1996; Santini and others, 2003).

The main difference between JDM and SDM is that the latter incorporates slightly higher slip near the downdip end of the rupture, to explain the horizontal displacements. Additionally, the rupture in the SDM is assumed to occur deeper than in the JDM. Consequently, the deeper subfaults in the SDM produce smoother variation of the sea floor deformation than in the JDM. Both models introduce the Patton Bay splay fault to explain the excessive uplift at Montague Island. It is assumed in the JDM that the extent of this splay fault was not much larger than its subaerial outcrop on Montague Island. On the other hand, it is assumed in the SDM that the same fault extends much farther to the west than was previous assumed by Holdahl and Sauber (1994) and Johnson and others (1996). We note that although the Patton Bay fault

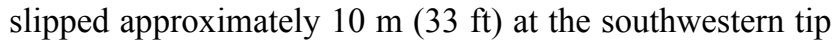
of Montague Island, there has yet to be a comprehensive submarine survey to document the extent of that splay fault.

Scenario 1. Repeat of the 1964 event: Source function based on coseismic deformation model by Johnson and others (1996) (JDM)

The 1964 earthquake vertical coseismic displacement is modeled as rupture by eight subfaults representing the Kodiak asperity and nine subfaults in the Prince William Sound asperity. One subfault was assigned to represent the Patton Bay fault, although the contribution of this fault to the farfield tsunami waveform was negligible. The fault parameters required to compute sea floor deformation are the epicenter location, area, dip, rake, strike, and amount of slip on the fault. We use the equations of Okada (1985) to calculate 
distribution of coseismic uplift and subsidence resulting from this slip distribution. This source function was previously applied to calculation of 1964 tsunami inundation in Kodiak and Kachemak Bay communities. The results are described in Suleimani and others $(2002,2005)$ and Nicolsky and others (2011b). The vertical ground/ocean floor displacement according to the JDM is shown in figure 10a.

Scenario 2. Repeat of the 1964 event: Source function based on coseismic deformation model by Suito and Freymueller (2009) (SDM)

This coseismic deformation model of the 1964 earthquake is based on a 3-D viscoelastic model, incorporating a realistic geometry with an elastic slab having low dip angle. The vertical ground/ocean floor displacement according to the SDM is shown in figure $10 \mathrm{~b}$.

\section{Models of the Multi-Segment Great Alaska Earthquake}

A recent study by Shennan and others (2009) presents geologic evidence that the Prince William Sound and Kodiak Island segments of the 1964 rupture area and a portion of the Yakutat microplate may rupture simultaneously. To evaluate whether this event would make a plausible tsunami scenario for Valdez, we have constructed a source function of the multi-segment rupture that encompasses the 1964 rupture.

We apply the following constraints based on the hypothetical earthquake model of Shennan and others (2008). The extended source function includes three segments of the Aleutian megathrust: Prince William Sound (PWS), Kodiak Island (KI), and Yakataga-Yakutat (YY) segments. The total seismic moment is about 15 percent greater than that of the 1964 earthquake. The new source function produces coseismic vertical uplifts along the Gulf of Alaska coastline segment between the Copper River basin and Yakataga area, in order to match the coseismic deformation pattern to paleoseismic data (Shennan and others, 2009).

To construct a rupture model for the YY segment, we assume four subfaults whose parameters are listed in table 2 . We calculate coseismic deformations produced by this segment using Okada's algorithm (Okada, 1985), and then combine them with the 1964 coseismic deformations produced either by the JDM or by the SDM.

Scenario 3. Multi-Segment JDM event: Source function based on extension of the JDM

The model in scenario 1 is extended by including a rupture model for the YY segment. The vertical coseismic deformation pattern for the extended 1964 rupture is shown in figure $10 \mathrm{c}$.

Scenario 4. Multi-Segment SDM event: Source function based on extension of the SDM

The model in scenario 2 is extended by including a rupture model for the YY segment. The vertical coseismic deformation pattern for the extended 1964 rupture is shown in figure $10 \mathrm{~d}$.
Scenario 5. Rupture of the Yakutat-Yakataga segment

The event is a hypothetical earthquake that ruptures the YY segment, which we parameterize by four sub-faults listed in table 1 . The vertical coseismic deformations for this scenario are shown in figure $10 \mathrm{e}$.

\section{Model of the Cascadia Subduction Zone Earthquake}

Paleoseismic records reveal that great tsunamigenic earthquakes repeatedly occur in the Cascadia subduction zone with irregular intervals averaging about 500 years (Atwater, 1987), often accompanied by a tsunami. The latest trans-Pacific tsunami generated by an earthquake at Cascadia occurred in January 1700 (Satake and others, 1996; Atwater and others, 2005). Probably owing to low population density along the Alaska coast, the impact of this tsunami on local communities was not noticed. Multiple models of the Cascadia zone rupture are suggested by Satake and others (2003) and Priest and others (2009) and in references therein. These models describe hypothetical coseismic displacement fields of the Cascadia rupture, with various levels of detail. Because a Cascadia subduction zone earthquake is considered to be a medium-distance tsunami source to the south-central Alaska coast, a relatively simple "worst case, but credible" rupture of the Cascadia subduction zone is used in our modeling.

Scenario 6. Rupture of the Cascadia zone, including portions of the margin along the British Columbia and northern California shores

Tsunami heights in Japanese historical records can constrain the slip distance of the 1700 Cascadia earthquake (Satake and others, 1996), but do not well constrain the downdip limit of the rupture (Wang and others, 2003). A conservative approach for Cascadia is to assume that full coseismic rupture takes place over the entire locked zone and the slip decreases linearly downdip halfway into the present effective transition zone. The most recently updated and probably more reasonable model assumes that the slip distribution in the downdip direction is bell shaped on a plot of slip versus distance from the trench (Geological Survey of Canada, K. Wang, written commun., 2010), which is different from what was used to model the coseismic deformation shown in figure 14 of Wang and others (2003). In this report, the assumed rupture recovers 1,200 years equivalent of plate convergence (Witter and others, 2011), about $36 \mathrm{~m}$ (120 ft) slip and its magnitude $\mathrm{M}_{\mathrm{w}} \approx 9$ and is shown in figure $10 \mathrm{f}$.

\section{Tectonic Source Models of Hypothetical Tsunamigenic Earthquakes}

The results of joint inversion of tsunami and geodetic data from the 1964 earthquake (Johnson and others, 1996) support the division of the rupture zone into two different segments: The Kodiak segment and the Prince William Sound (PWS) segment. These zones have different recurrence intervals, with estimates of the recurrence interval for the Kodiak segment being as low as 60 years (Johnson and others, 1996). 
Therefore, we consider four scenarios in which these two segments of the 1964 rupture area are separate hypothetical tsunami sources.

Scenario 7. Modified 1964 event: Prince William Sound asperity of the JDM

This event is a hypothetical earthquake that ruptures nine subfaults of the Prince William Sound asperity with some slip on the Patton Bay fault from the deformation model by Johnson and others (1996). Vertical coseismic deformations for this scenario are shown in figure $10 \mathrm{~g}$.

Scenario 8. Modified 1964 event: Kodiak asperity of the JDM

This event is a hypothetical earthquake that ruptures eight subfaults in the Kodiak asperity from the deformation model by Johnson and others (1996). Vertical coseismic deformations for this scenario are shown in figure $10 \mathrm{~h}$.

Scenario 9. Modified 1964 event: Prince William Sound asperity of the SDM

This event is a hypothetical earthquake that ruptures the Prince William Sound asperity from the deformation model by Suito and Freymueller (2009). Vertical coseismic deformations for this scenario are shown in figure $10 \mathrm{i}$.

Scenario 10. Modified 1964 event: Kodiak asperity of the $S D M$

This event is a hypothetical earthquake that ruptures the Kodiak asperity from the deformation model by Suito and Freymueller (2009). Vertical coseismic deformations for this scenario are shown in figure $10 \mathrm{j}$.

\section{Other Tectonic Source Models of Hypothetical Tsunamigenic Earthquakes}

In addition to the already considered earthquakes, we present two additional source models that are related to a simultaneous rupture of the PWS block and the YY segment.

Scenario 11. Modified multi-segment JDM event: Rupture of the PWS and YY segments

This event is a hypothetical earthquake, modeled as a rupture of the PWS block, Patton Bay fault, and the YY segment. The rupture of the PWS block is parameterized by nine subfaults, and the Patton Bay fault is modeled according to the JDM. Parameters of the four subfaults defining the rupture of the YY segment are listed in table 2, and vertical coseismic deformations for this scenario are shown in figure 10k.

Scenario 12. Modified multi-segment SDM event: Rupture of the PWS and YY segments

This event is a hypothetical earthquake, modeled as a rupture of the PWS block, Patton Bay fault, and the YY segment. The rupture of the PWS block and the Patton Bay fault is modeled according to the SDM. Parameters of the four subfaults defining the rupture of the YY segment are listed in table 2, and vertical coseismic deformations for this scenario are shown in figure 101 .
Tectonic Source Models of Hypothetical Tsunamigenic Earthquakes with a subsidence in Port Valdez

In recent studies, Carver and Plafker (2008) and Shennan and others (2008) presented evidence of multiple great earthquakes rupturing the Alaska megathrust and significant ground surface displacement along the Gulf of Alaska shoreline. Although estimated values of the ground subsidence and uplift are available only at a limited number of locations (Hamilton and Shennan, 2005; Shennan and others, 2008; Carver and Plafker, 2008), they indicate that tectonic plates could have slipped differently relative to each other during each earthquake. The available ground deformation data are scarce and do not allow constraints on the slip distribution in the vicinity of Port Valdez or estimates on the location of the zero isobase between coseismic uplift and subsidence displacements during pre-1964 great megathrust events. The zero isobase during the 1964 event (Plafker, 1969) lies just south of Port Valdez, but could have been located slightly farther south. Subsidence in the Port Valdez region may have been greater during pre-1964 events. If this is the case, more devastating tectonic tsunamis than occurred in 1964 in Port Valdez are possible. Thus, in addition to assessing the 1964-type events, we consider several scenarios of the hypothetical earthquakes rupturing the so-called plate interface- - a boundary between two tectonic plates - beneath the Prince William Sound region. We hypothesize that during such an event a hypothetical tsunami arrives to the tectonically subsided city of Valdez.

Recall that the northeastern part of the megathrust is a complex collision zone where the Yakutat microplate moves northwest toward central Alaska (for example, Carver and Plafker, 2008). In view of this, there is a substantial uncertainty in the location of the plate interface beneath Prince William Sound. Moreover, according to Freymueller and others (2008) and references therein, there is uncertainty as to how many subduction interfaces exist beneath the Prince William Sound region. The substantial amount of plate motion may be accommodated on the Yakutat-North America interface, the likely interface that ruptured in 1964 (Freymueller and others, 2008, and references therein). The Pacific-Yakutat plate interface is thought to lie deeper beneath Prince William Sound than the Yakutat-North American plate interface. One hypothesis is that the Yakutat block diminishes to the west, such that the two interfaces merge somewhere to the west of Prince William Sound (Freymueller and others, 2008). It is possible that a subduction-type earthquake could occur along the Pacific-Yakutat plate interface. However, further research is necessary to construct plausible worst-case scenarios for this plate interface.

A model of the Alaska-Aleutian plate interface has been developed by Hayes and others (2012). On examination of the depth contours associated with this model in the Prince William Sound region (Douglas Christensen, UAF, 2012, oral commun.), we amended this interface with the depth contour reconstructions and profiles by Doser and others (1999), Page and others (1991), Wolf and others (1991), and Moore and others (1991), as well as the earthquake hypocenters recorded by the Alaska Earthquake Information Center/University of 


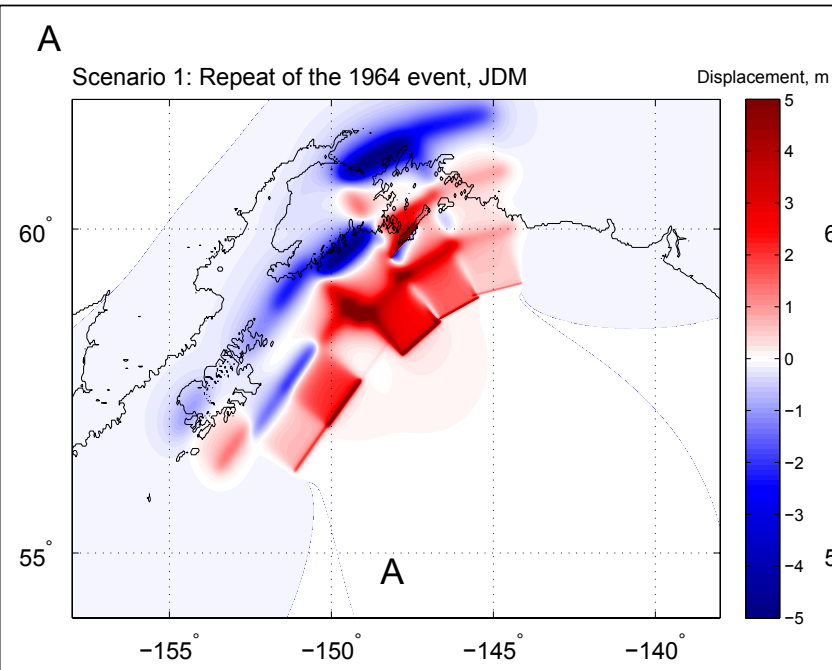

B

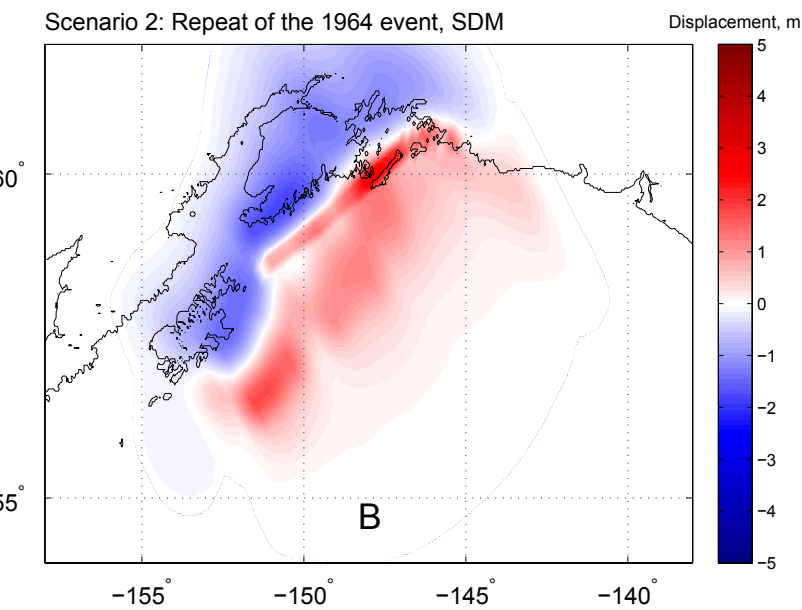

C

D
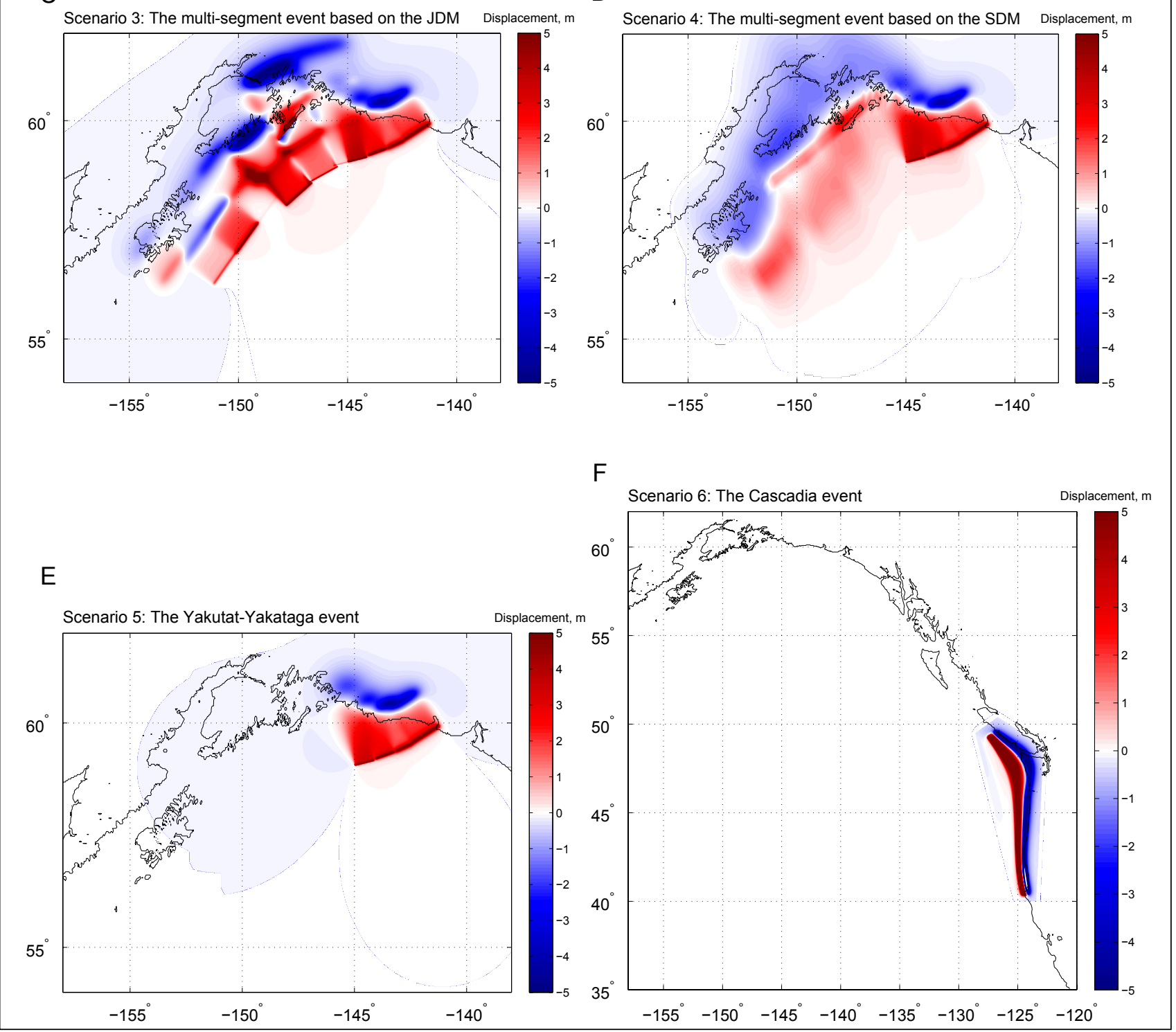

Figure 10. Vertical deformations of the ocean floor and adjacent coastal region in meters, corresponding to scenarios 1-12. Red indicates uplift; blue indicates subsidence. 


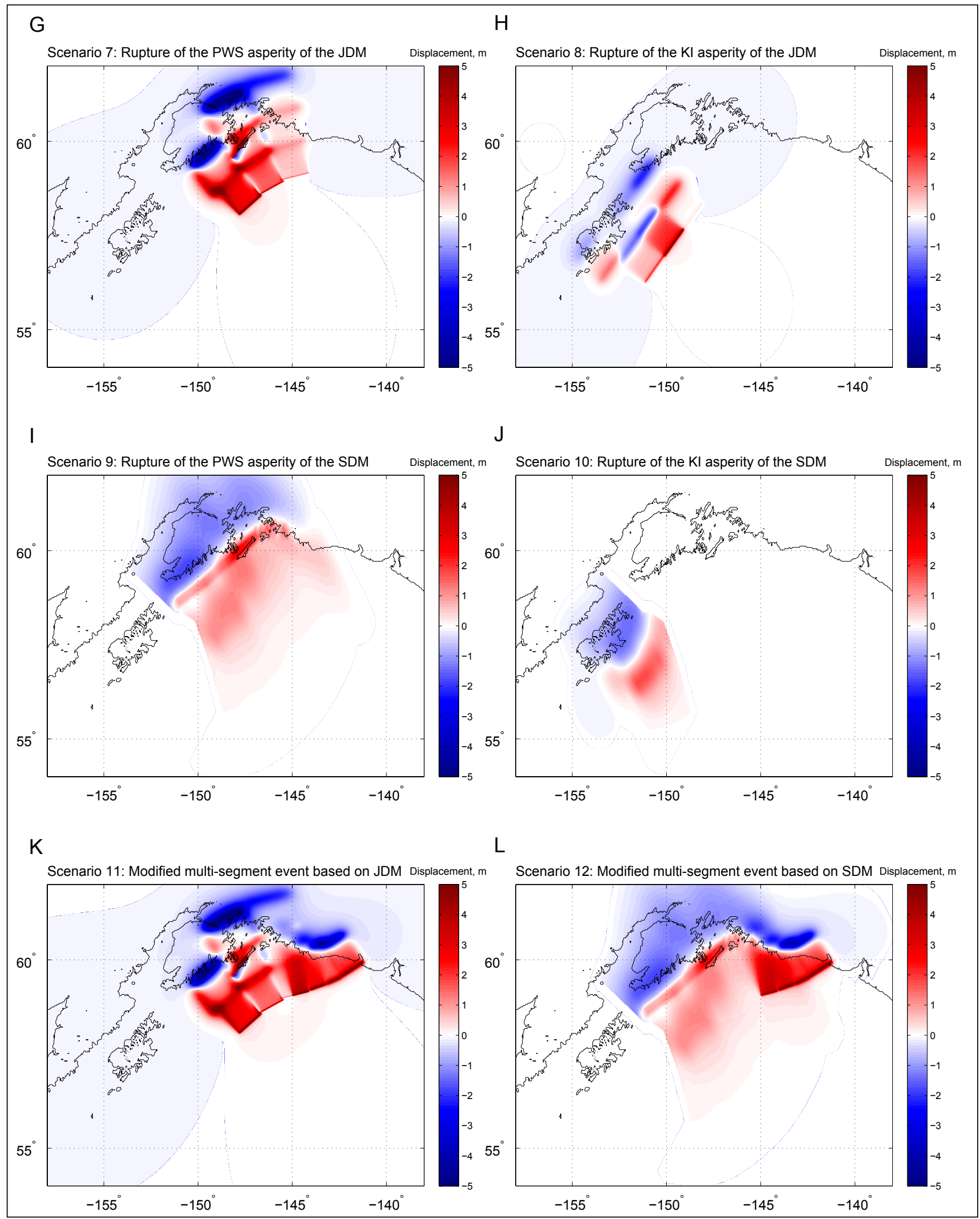

Figure 10 (continued). Vertical deformations of the ocean floor and adjacent coastal region in meters, corresponding to scenarios 1-12. Red indicates uplift; blue indicates subsidence. 
Alaska Fairbanks (AEIC/UAF). We fit a least squares surface to the upper limit of the hypocenter locations for subduction earthquakes recorded below $30 \mathrm{~km}$ (N. Ruppert, AEIC/UAF, 2012, written commun.) and all above-mentioned depth contour reconstructions. The amended model of the plate interface in the Gulf of Alaska is presented in figure 11. The plate interface depths in the Prince William Sound region are primarily determined by the depth contours of Doser and others (1999); however, our reconstruction does not reveal small-scale features. Similar to the reconstruction by Zweck and others (2002), our plate interface model exhibits a relatively shallow dip angle beneath the Kenai Peninsula

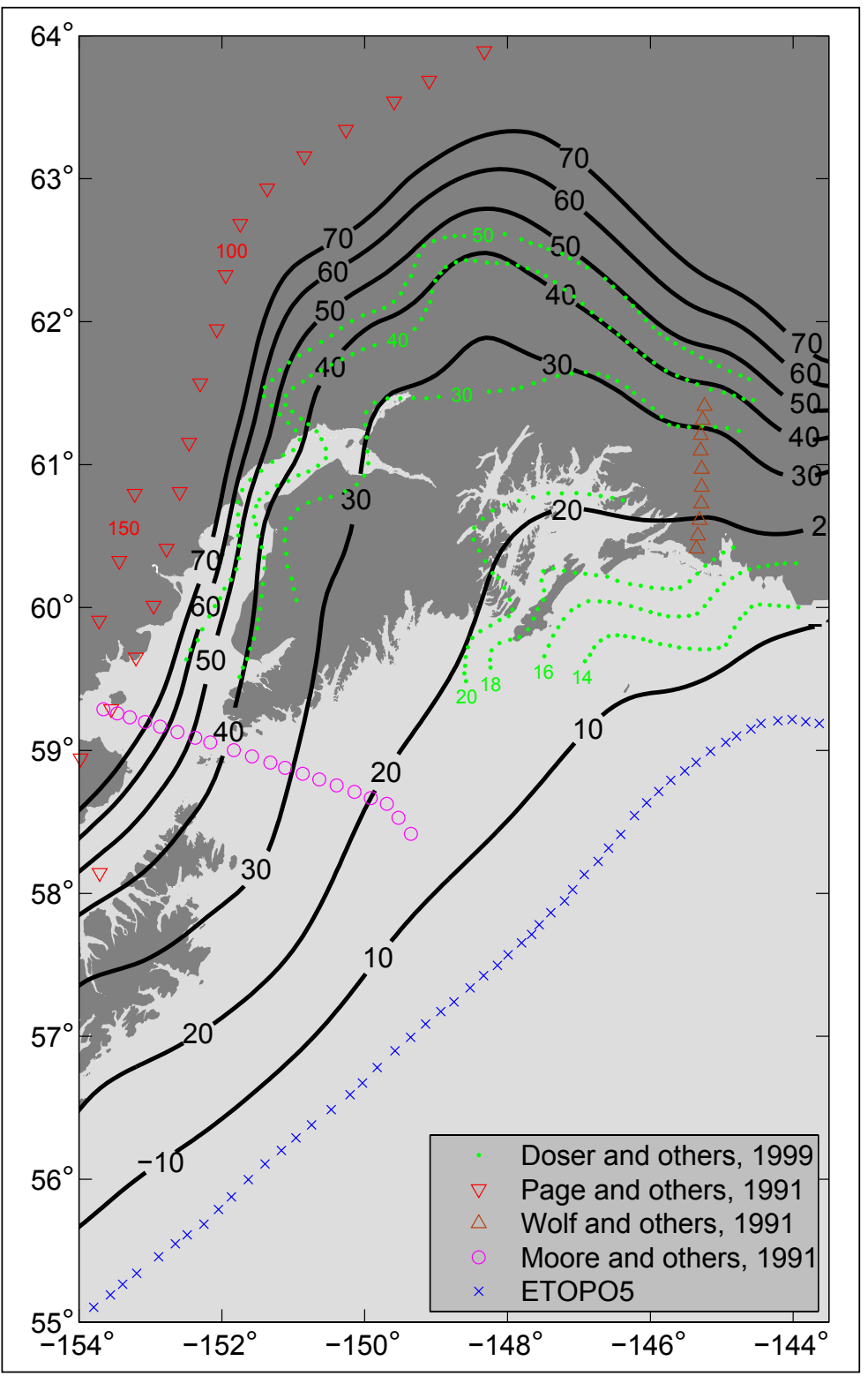

Figure 11. Interpolated plate interface depth (in kilometers) between Kodiak Island and Prince William Sound. The original data sources are marked by different symbols and are listed in the legend. The zero depth contour is associated with the Alaska-Aleutian trench location from the ETOPO5 dataset. The data are courtesy of Jeffrey Freymueller, Geophysical Institute/University of Alaska Fairbanks. and Prince William Sound until it reaches a depth of $50 \mathrm{~km}$ (31 mi), where it transitions to steeper dip. The developed model closely resembles smoother plate interface contours of Zhao and others (1995), Doser and others (2005), and Suito and Freymueller (2009). Once the surface modeling of the plate interface is computed, we discretize the surface into a number of small rectangles. An upper and lower edge of each rectangle is coincident with a depth contour of the reconstructed plate interface (fig. 12). Red lines mark depth contours of the plate interface. The rectangles, or so-called sub-faults, are later used to compute coseismic ground deformation using formulae in Okada (1985).

To prescribe slip along the plate interface, we use theoretical slip distribution formulae by Freund and Barnett (1976). Their formulae define slip in the local down-dip fault coordinates and are employed (for example, Geist and Dmowska, 1999; Sobolev and others, 2007) to model coseismic vertical deformation. The most important parameters in the Freund and Barnett formulae are the upper and lower boundaries of the hypothetical rupture in the local down-dip direction. These boundaries prescribe a range of depths at which the hypothetical earthquake occurs. In figure 13, we show two parameterizations of the slip distribution in the down-dip direction. The slip variation is non-dimensional and it is later scaled to obtain an earthquake with a specific moment magnitude. In case $\mathrm{A}$, the rupture occurs between depths of 15 and $25 \mathrm{~km}(9.3-15.5 \mathrm{mi})$, and in case $\mathrm{B}$, the rupture is limited between depths of 17 and $30 \mathrm{~km}$ (10.5-18.6 mi). Note that an area under the curve is the same in both cases, and that in case A the rupture area is shorter in the down-dip direction and the slip distribution is more concentrated.

In figure 14, we show two theoretical scenarios of the slip distribution for $\mathrm{M}_{\mathrm{w}} 8.8$ earthquakes in the Prince William Sound region. Slip at the center of each sub-fault is in meters and is marked by color; depth contours of the plate interface model are in kilometers and are shown by red lines. The location of the city of Valdez is marked by a yellow circle. We employ cases A and B to define the slip in the down-dip direction, while the slip in the along-strike direction is thought to be distributed uniformly and is tapered at each end of the rupture zone. Note that in case A, the maximum slip occurs south of Port Valdez at the $20 \mathrm{~km}$ (12.4 mi) depth, while in case $\mathrm{B}$, the maximum slip occurs below Port Valdez at about the $23 \mathrm{~km}(14.3 \mathrm{mi})$ depth. Once the slip distribution on the plate interface is specified, we compute the slip at the center of each sub-fault and then employ Okada (1985) formulae to calculate the vertical deformation. The vertical deformations for each case are displayed in figure 15. Blue indicates ground subsidence, while red marks areas of uplift. Note that in case A, Port Valdez is in the area of maximum subsidence, and 
Figure 12. Discretization of the plate interface model into a set of rectangles used to compute the coseismic vertical displacement by Okada's (1985) formulae. The red lines mark depth contours (in kilometers) of the reconstructed plate interface.

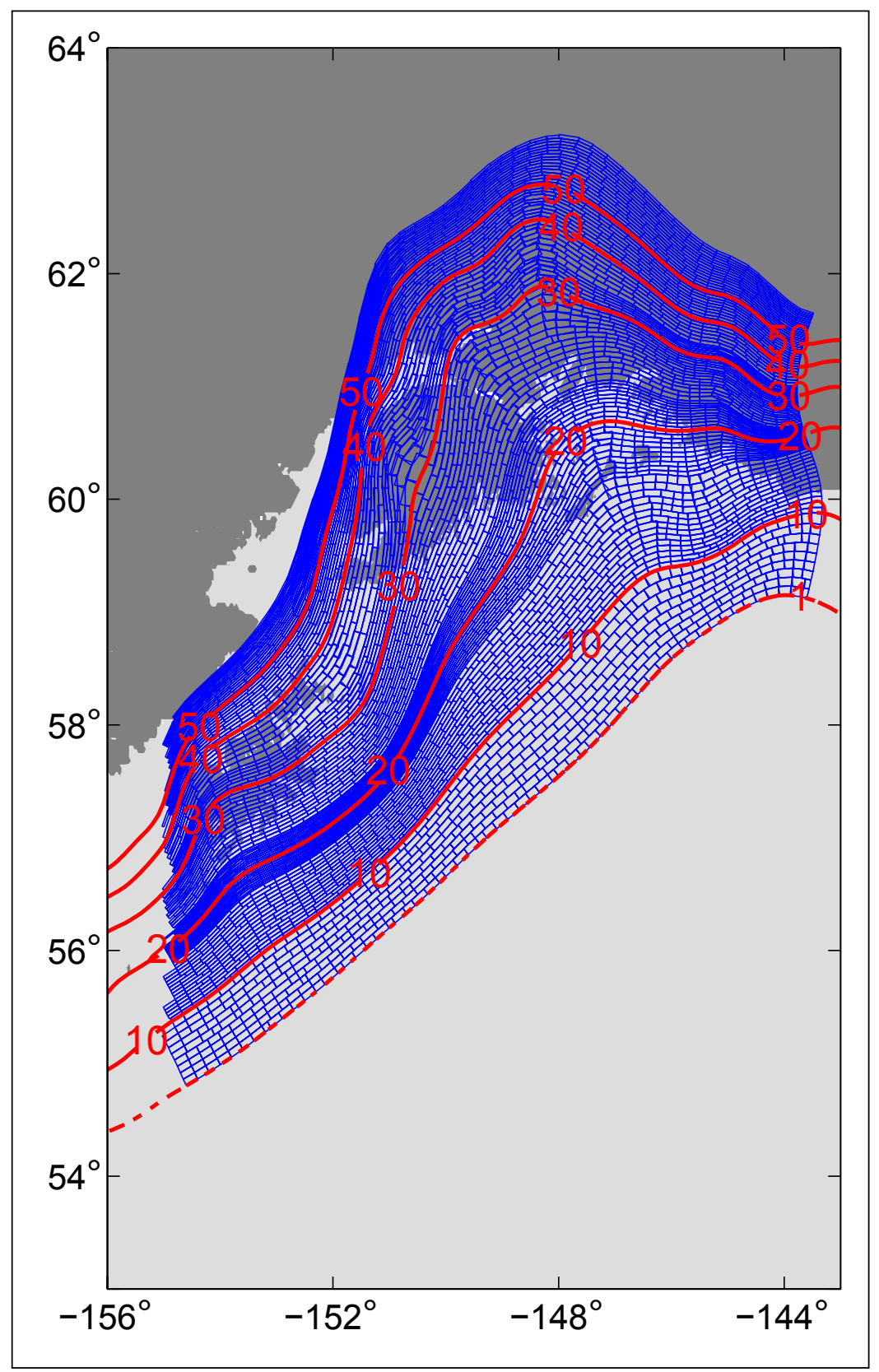

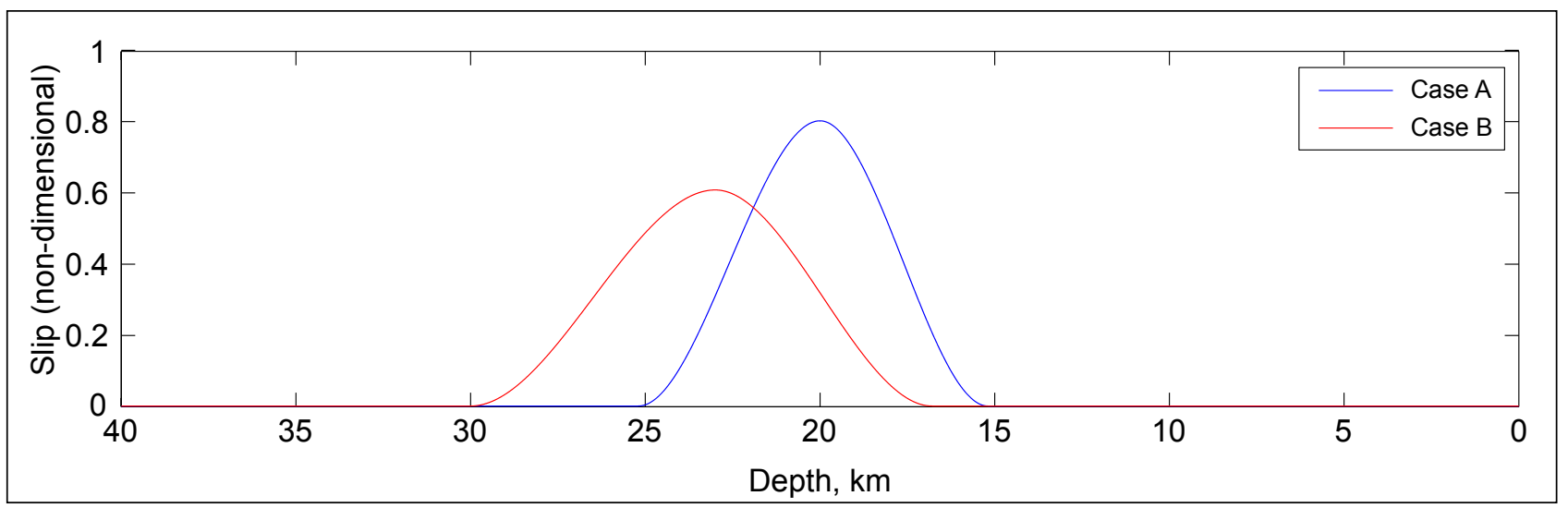

Figure 13. Assumed down-dip slip distribution for cases A and B. The parameterization is based on the analytical approximation by Freund and Barnett (1976). 


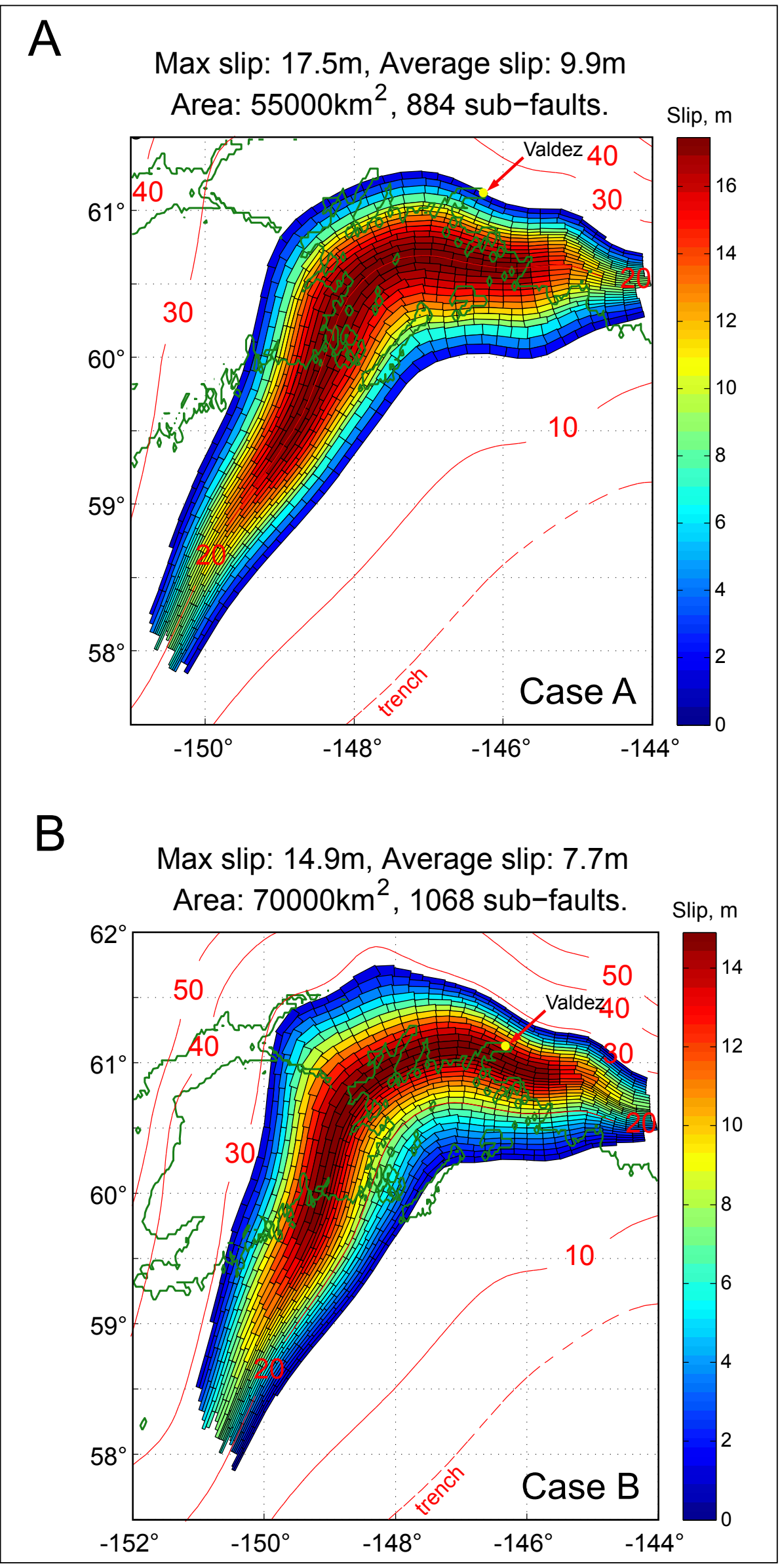

Figure 14. Proposed slip distribution along the plate interface for cases $A$ and $B$, shown in figure 13. Red lines are associated with the depth contours (in kilometers). Location of Valdez is marked by a yellow point. 


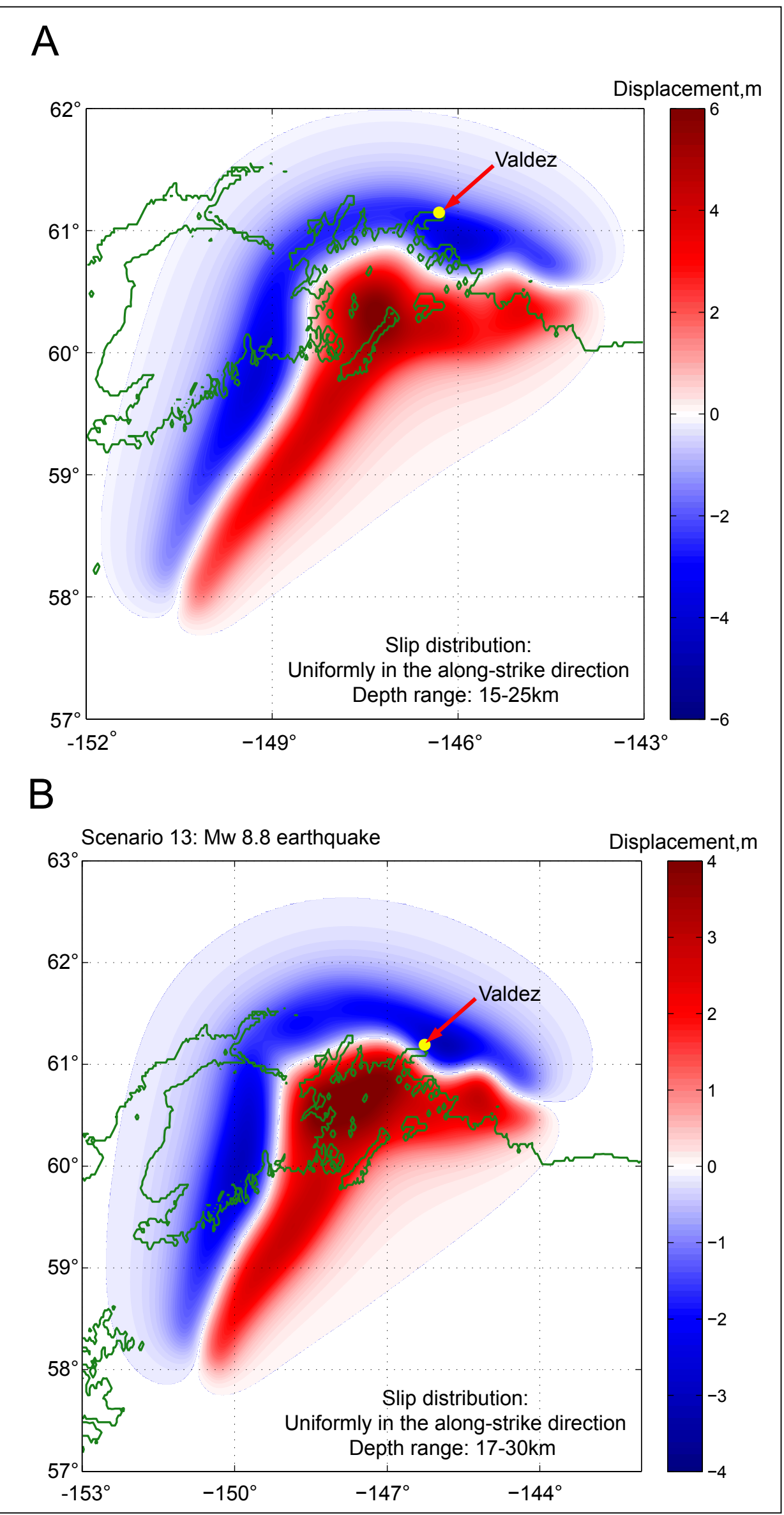

Figure 15. Computed vertical ground surface deformation related to cases $A$ and $B$, shown in figure 14. Blue areas are associated with the coseismic ground subsidence, while areas of uplift are shown in red. Note the location of the zero deformation line with respect to Valdez. The deformation on the bottom plot is considered to be scenario 13 and is used to assess the tsunami hazard in Port Valdez. 
if such an earthquake occurs the city can theoretically subside by almost 2.5-3.0 m (8.2-9.8 ft), while for case B Port Valdez is near the zero contour line of the vertical deformation, and the city potentially subsides by $1.0-1.5 \mathrm{~m}(3.3-4.9 \mathrm{ft})$.

Unfortunately, there are no geological data to explicitly constrain the potential subsidence in Port Valdez. The closest locations where paleoseismic data are available to estimate submergence are Girdwood, Portage, and perhaps Kenai. Note that submergence can exceed tectonic subsidence in the Portage and Girdwood flats due to sediment compaction. At Girdwood the estimated submergence ranged from 0.7 to $\approx 1.5 \mathrm{~m}(2.3-4.9 \mathrm{ft})$ in six pre-1964 events dating to $\approx 3.7 \mathrm{ka}$ (Shennan and others, 2008, p. 194) but was typically $\approx 1.5 \mathrm{~m}(4.9 \mathrm{ft})$ as in 1964. Shennan and others (2012) estimated subsidence at Portage for seven paleoseismic events recorded in a borehole. The four most recent and better constrained events, dating to $2.5 \mathrm{ka}$, yielded estimated submergence of $1.2-1.6 \pm 0.5 \mathrm{~m}(3.9-5.2 \pm 1.6 \mathrm{ft})$. Note that in 1964 subsidence at Portage was $\approx 1.8 \mathrm{~m}(5.9 \mathrm{ft})$. Three older, less well constrained events had estimated submergence of $0.3-0.6 \pm 0.6 \mathrm{~m}(1-2 \pm 2 \mathrm{ft})$ (Shennan and others, 2012). The data at Girdwood and Portage seem to suggest that subsidence can vary by up to $\approx 1 \pm 0.5 \mathrm{~m}(3.3 \pm 1.6 \mathrm{ft})$. Considering that the subsidence variation could be greater or less at other locations across the deformation field, this range is the only geologic constraint to the subsidence in Port Valdez.

We hypothesize that subsidence in Port Valdez may vary within the same range as the subsidence in Girdwood and Portage. Recall that the scenario based on case A results in 2.5-3.0 m (8.2-9.8 ft) of subsidence in Port Valdez. The latter value is likely to be outside of plausible limits from a geological perspective, given that Port Valdez tectonically subsided by $0.3-0.6 \mathrm{~m}$ (1-2 ft) during the 1964 event. Therefore, although both scenarios of the $M_{w} 8.8$ earthquake are theoretically plausible from a seismological point of view, the scenario based on case A is omitted because of geological constraints, and we only consider the scenarios based on case B.

Scenario 13. $M_{w} 8.8$ earthquake in the Gulf of Alaska region: 17-30 km (10.5-18.6 mi), uniform slip along strike

This event is a hypothetical $M_{w} 8.8$ earthquake rupturing the Prince William Sound asperity of the 1964 earthquake. The slip is uniformly distributed in the along-strike direction of the plate interface and is localized between 17 and $30 \mathrm{~km}$ (10.5-18.6 $\mathrm{mi}$ ) depth according to the parameterization in case B. Vertical coseismic deformations for this scenario are shown in figure 15.

A geodetic study by Zweck and others (2002) in south-central Alaska revealed the so-called locked regionssegments of the plate interface where the tectonic plates do not move relative to each other due to intense friction. Zweck and others (2002) showed that the locked regions are located beneath the eastern Kenai Peninsula and western Prince William Sound at depths from 10 to $30 \mathrm{~km}(6.2-18.6 \mathrm{mi})$ and correlated this locked zone to the region of high slip during the 1964 earthquake. They conclude that the locked zone is associated with a persistent asperity. Suito and Freymuller (2009) estimated the slip deficit accumulating on the locked plate interface and found that most of the slip deficit (locking) occurs near southeastern Kenai Peninsula, near Bainbridge and Evans Islands. The estimated slip deficit contours from Suito and Freymuller (2009) are shown in figure 16.

We construct two additional scenarios for the hypothetical tsunamigenic earthquakes. In both scenarios, instead of assuming a uniform slip distribution in the along-strike direction of the potential rupture, we propose to adjust the slip according the slip deficit model by Suito and Freymuller (2009).

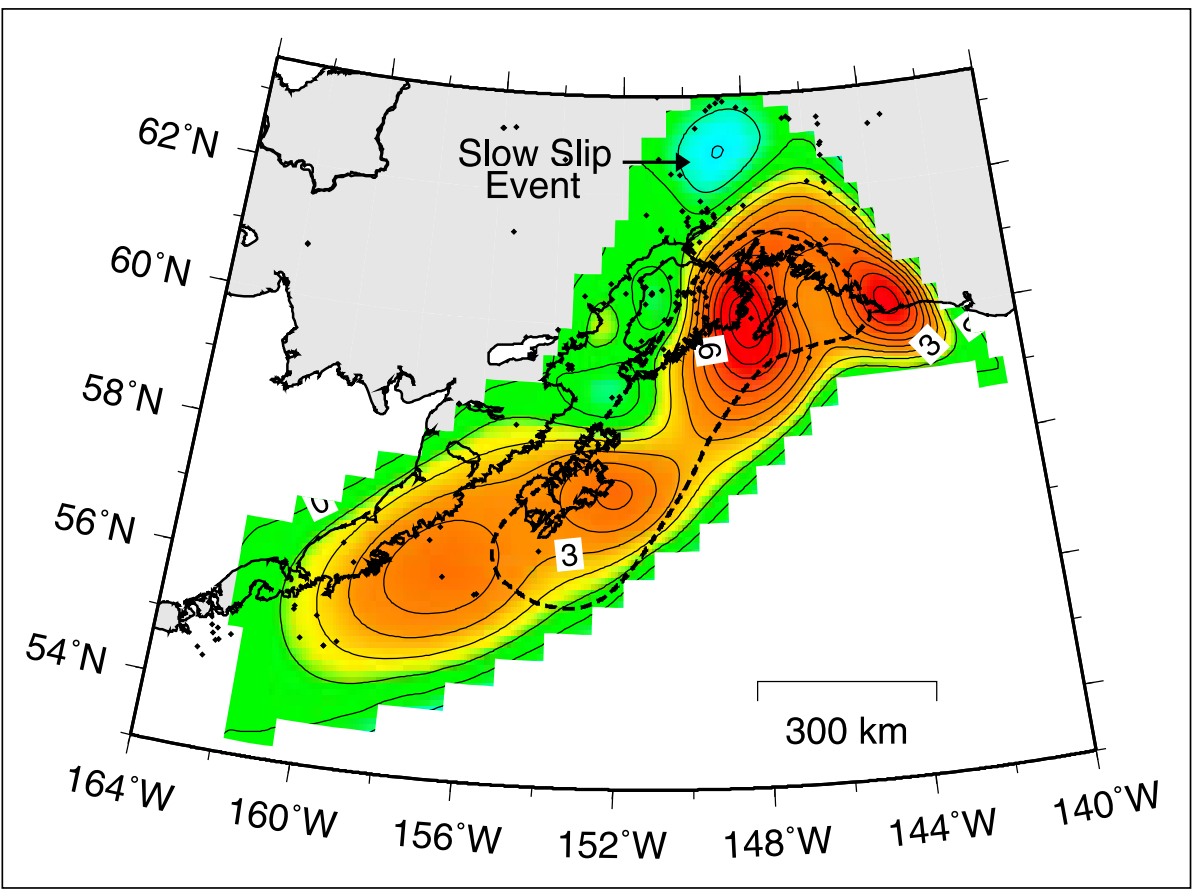

Figure 16. Contour plot (from Suito and Freymueller, 2009) of the interseismic slip deficit reconstruction, with contour interval of $1 \mathrm{~cm}$ (0.39 in) per year. Red colors are positive slip deficits, and blue colors are negative slip deficits (mainly the effect of the 1998-2001 slow slip event [Ohta and others, 2006]). 
Scenario 14. $M_{w} 8.8$ earthquake in the Gulf of Alaska region. $13-28 \mathrm{~km}$ (8.1-17.4 mi), variable slip along strike

This event is a hypothetical $\mathrm{M}_{\mathrm{w}} 8.8$ earthquake rupturing the Prince William Sound asperity of the 1964 earthquake. The slip is distributed in the along-strike direction according to the slip deficit model (Suito and Freymuller, 2009) and is localized between 13 and $28 \mathrm{~km}(8.1-17.4 \mathrm{mi})$ depth according to the parameterization by Freund and Barnett (1976).

Scenario 15. $M_{w} 8.8$ earthquake in the Gulf of Alaska region: $12-29 \mathrm{~km}(7.5-18 \mathrm{mi})$, variable slip along strike

This event is a hypothetical $\mathrm{M}_{\mathrm{w}} 8.8$ earthquake rupturing the Prince William Sound asperity of the 1964 earthquake. The slip is distributed in the along-strike direction according to the slip deficit model (Suito and Freymuller, 2009) and is localized between 12 and $29 \mathrm{~km}$ (7.5-18 mi) depth according to the parameterization by Freund and Barnett (1976).

The extent of the rupture in the down-dip direction for scenarios 14 and 15 is chosen such that coseismic subsidence occurs in Port Valdez. In addition to this requirement, the maximum and average slip on the plate interface as well as the rupture zone area have to match magnitude-slip displacement scaling relations developed for subduction earthquakes (Papazachos and others, 2005; Moss and Travasarou, 2006). The proposed slip distributions for scenarios 14 and 15 are shown in figure $17 \mathrm{a}$ and $17 \mathrm{~b}$, respectively. The computed vertical coseismic displacements are shown in figure 18.

\section{LANDSLIDE TSUNAMI SOURCES}

\section{Multiple Submarine Slope Failures in Port Valdez During the 1964 Earthquake}

Coulter and Migliaccio (1966), Plafker and others (1969), and Wilson and Tørum (1972) analyzed the underwater slope failures in Port Valdez during the 1964 event and described damage to the infrastructure in Valdez by landslide-generated waves. In addition, Coulter and Migliaccio (1966) indicated that the post-earthquake slopes in Port Valdez are nearly parallel to the pre-earthquake slopes, and consequently hypothesize that a seismic tremor might cause the sediment to liquefy and slide into the bay again. Moreover, analyses by Begét (2007), Lee and others (2007), and Ryan and others (2010) provide a convincing view that massive submarine landslides in Port Valdez may occur in the future. Thus, we have developed several hypothetical scenarios of major underwater slope failures in Port Valdez

Scenario 16. Repeat of the 1964-type event: An underwater slide at the head of Port Valdez (HPV slide).

Without knowing the rheology of the sediment composing the slopes of Port Valdez, and in the absence of an underwater slope stability analysis, multiple debris lobes in Port Valdez provide the only available data to estimate the volume of future landslides. Comparison of the pre-1964 debris lobes to the 1964 lobe in Port Valdez reveals that variations in the thickness and spatial extent of the debris lobes are probably tied to the amount of sediment that has accumulated at the fjord-head delta in eastern Port Valdez (Ryan and others, 2010).

Considering that the time interval between the penultimate and 1964 earthquakes was about 900 years - the longest interseismic interval according to Carver and Plafker (2008) - there was a longer time period for the sediment accumulation prior to the 1964 event compared to the previous seismic cycles. Moreover, the advance of glaciers during the Little Ice Age likely also contributed more sediment to the edge of the fjord than in non-glacial times. Additionally, Ryan and others (2010) propose that during a warmer period following the Little Ice Age, the Valdez Glacier retreat caused an increase in sedimentation to the fjord-head delta. The latter results in thicker deposits of unconsolidated sediment with low shear strength (for example, Hampton and others, 1996), which may be more prone to large failures when triggered by a megathrust earthquake. This conjecture about an increased accumulation of sediments due to a longer seismic cycle and the climate variations between the penultimate and 1964 earthquake is consistent with the observations. Namely, the thickest and most extensive debris lobes were generated during the 1964 and penultimate events during the twentieth century and the Medieval Warm Period, respectively (Ryan and others, 2010). Thus, taking into account special conditions prior to the 1964 and penultimate events, we hypothesize that a total volume of potential slides can approximately be between 50 percent and 75 percent of the 1964 slide volume (the penultimate slide has much larger uncertainties than the 1964 slide, and there are no estimates for the volume of the penultimate slide). However, if the rate of sediment accumulation at the fjord head increases with respect to its pre-1964 value, a total volume of potential slide might be comparable to or greater than the volume of the 1964 slide. Currently, the sediment accumulation at the Lowe River mouth delta is estimated to be about 8 million $\mathrm{m}^{3}$ (10 million $\mathrm{yd}^{3}$ ) in 37 years between 1966 and 2003.

It is difficult to accurately estimate the 1964 slide. According to Coulter and Migliaccio (1966), a slide near the old townsite $\left(\mathrm{HPV}_{64}\right)$ was about 75 million $\mathrm{m}^{3}$ (98 million $\left.\mathrm{yd}^{3}\right)$. Our computations show that approximately 55 million $\mathrm{m}^{3}$ (72 million $\left.\mathrm{yd}^{3}\right)$ of sediment slid into the port during the 1964 event between the harbor and the present-day Lowe River mouth delta. We emphasize that these are the estimates of the material that failed in the vicinity of the old town during the 1964 event. As the 1964 slide progressed down the slope and on to the fjord bottom, the slide incorporated more material from the seafloor. Ryan and others (2010) computed the total volume of the 1964 debris lobe at 1,000 million $\mathrm{m}^{3}$ $\left(1,300\right.$ million $\left.\mathrm{yd}^{3}\right)$, including the volume of the slide near Shoup Bay and the volumes of all intermittent slides since the penultimate earthquake. From a tsunami modeling perspective, an initial landmass failure located on a fjord wall has a much greater potential to produce a tsunami than the material scraped by the slide off the bottom. Therefore, it is crucial to estimate an initial volume of the potential landmass failures around Port Valdez. In this report, we only provide estimates of the initial mass failures. 


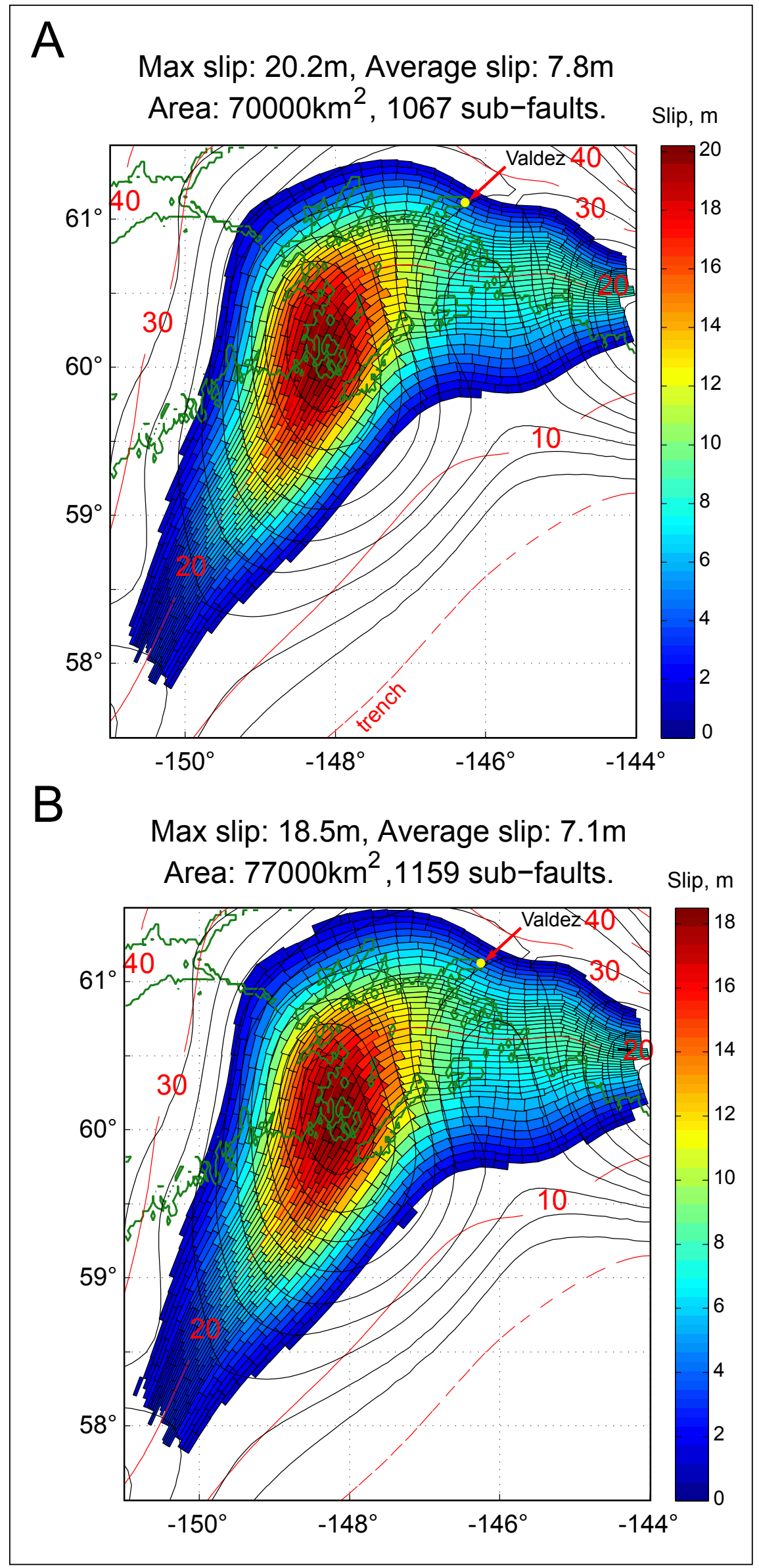

Figure 17. Proposed slip distribution at the plate interface in the along-strike direction is parameterized according to Suito and Freymueller's 2009 slip-deficit model. Red lines are associated with depth contours (in kilometers); slip-deficit contours are shown by black lines. Valdez is marked by a yellow point. 


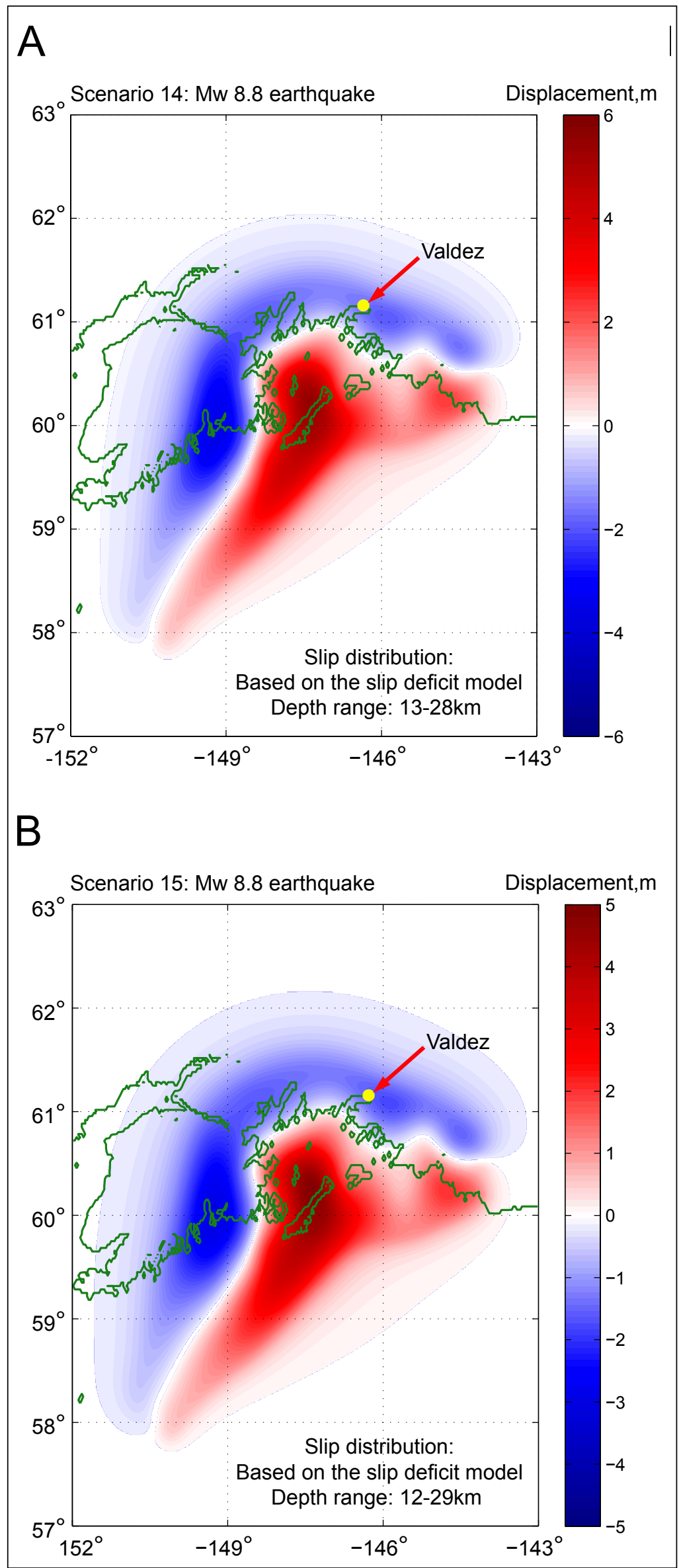

Figure 18. Computed vertical ground-surface deformation related to cases $A$ and $B$, shown in figure 17. Blue areas are associated with the coseismic ground subsidence, while areas of uplift are shown in red. Note the location of the zero deformation line with respect to Valdez. The deformation on the top and bottom plots is associated with scenarios 14 and 15, respectively. 
Based on the above-mentioned estimates of the 1964 slide volume near the old town, we thus hypothesize that a volume of the HPV slide is at least 55 million $\mathrm{m}^{3}$ (72 million $\left.\mathrm{yd}^{3}\right)$, however, the upper boundary of the slide volume is . We assume that the volume of the HPV slide is of the order of 75-100 million $\mathrm{m}^{3}$ (98-130 million $\left.\mathrm{yd}^{3}\right)$.

The 1964 debris lobe was the largest lobe in the study by Ryan and others (2010). However, Begét (2007) found older sand deposits at the locations that were not inundated by the 1964 tsunami, but could not date when they originated. Under these circumstances, we speculate that the pre-1964 landslide could have had an equal or smaller volume but a different geometry than that of the 1964 slide. It is thus necessary to take into account multiple possible configurations of the hypothetical massive landslide at the head of Port Valdez (HPV). Since failure surfaces of the hypothetical HPV landslide are largely uncertain, we consider several different sub-scenarios and an envelope sub-scenario. Each sub-scenario corresponds to a potential realization of the HPV slide with the volume of approximately 75 million $\mathrm{m}^{3}\left(98\right.$ million $\left.\mathrm{yd}^{3}\right)$. The first sub-scenario assumes that the deposit collapses uniformly along the submerged slopes at the eastern part of the bay. Other sub-scenarios assume that there is a specific location where most of the deposit fails. We consider three different locations for the main body of the slide: At the northeastern, center-eastern, and southeastern segments of the head of the port. For each sub-scenario, we specify bowl-shaped failure surfaces. Without geotechnical information we lack data to support alternative slide plane geometries, like a tabular shaped failure surface. After the failure surface is defined, we compute a thickness of the potential slide. Finally, the slide thickness for the envelope scenario is defined as a maximum slide thickness among all sub-scenarios. Volume of the slide associated with the

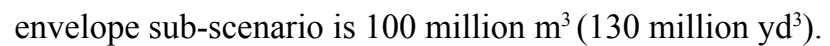

We abbreviate sub-scenarios by the scenario number and location of the main body for the slide. For example, scenario 13-north is sub-scenario associated with the HPV slide whose main body is in the northeastern part of Port Valdez. The slide thicknesses for each sub-scenario are shown in figure 19.

Scenario 17. Repeat of the 1964-type event: An underwater slide at the Shoup Bay moraine (SBM slide).

Failures from the fjord head delta contributed to all six of the debris lobes discussed in the Introduction; however, it appears that failure of the Shoup Bay moraine only took place during the 1964 and the penultimate events (Ryan and others, 2010). The recent multi-beam survey has found two 40-m- (130-ft-) high blocks intact and embedded into the shallowest debris lobe (Lee and others, 2007). The study by Ryan and others (2010) revealed a strong seismic reflector that is continuous beneath the block, and the authors attribute the origin of these blocks to the 1964 event. There is a common understanding that the SBM slide presents a significant hazard to the Port Valdez area. According to Begét (2007), following the 1964 earthquake, the subaerial Shoup Bay moraine was fractured and is cut by faults. The existence of the faults, probably initiated in 1964, may make the moraine more susceptible to failure and more likely to generate submarine landslides during future earthquakes.

As the postulated fault surfaces in the moraine are also uncertain, we follow the same technique as before and define two sub-scenarios and the envelope sub-scenario. The asperities for the sub-scenarios are located at the eastern and western parts of the Shoup Bay moraine. The volume of the slide related to each sub-scenario is approximately 116 million $\mathrm{m}^{3}\left(150\right.$ million $\left.\mathrm{yd}^{3}\right)$, while the volume of the slide associated with the envelope sub-scenario is 140 million $\mathrm{m}^{3}(183$ million $\left.\mathrm{yd}^{3}\right)$. The slide thicknesses for each sub-scenario are shown in figure 20.

\section{Hypothetical landslide tsunami sources}

In addition to the 1964-type scenarios, we consider possible hypothetical landslide locations on the northern shore of Port Valdez. Deltas of the creeks draining into glacial fjords are typically associated with locations of potential submarine landslides. Unfortunately, there is no geotechnical information to adequately constrain the locations and thicknesses of underwater slides anywhere in Port Valdez.

Scenario 18. Hypothetical event: An underwater slide offshore of Mineral Creek (MC slide).

There is a hypothesis that during the penultimate earthquake a landslide occurred offshore of the Mineral Creek delta (P. Haeussler, USGS, written commun., 2011). After determining a potential location of the $\mathrm{MC}$ slide and defining the failure surfaces to maximize the slide volume, we estimate a hypothetical volume of 20 million $\mathrm{m}^{3}\left(26\right.$ million $\left.\mathrm{yd}^{3}\right)$. The slide thickness and its location are shown in figure 21a.

Scenario 19. Hypothetical event: An underwater slide offshore of Gold Creek (GC slide).

The mouth delta of Gold Creek on the northern shore is another probable location of a submarine landslide. After determining a potential location of the GC slide and defining the failure surfaces to maximize the slide volume, we estimate a hypothetical slide volume of 8 million $\mathrm{m}^{3}\left(10\right.$ million $\left.\mathrm{yd}^{3}\right)$. The slide thickness and its location are shown in figure $21 \mathrm{~b}$.

Scenario 20. Hypothetical event: An underwater slide offshore of Lowe River (LR slide).

Lowe River and Valdez Glacier Stream transport large volumes of sand and silt from glaciers in the Chugach Mountains to Port Valdez. Comparison of the post-earthquake bathymetry (NOS H08899 and NOS H08900) and present-day bathymetry (high-resolution DEM) allows us to reconstruct accumulation of the alluvial sediments at the deltas of Lowe River and Valdez Glacier Stream from 1966 to 2003. The maximum thickness of the sediment accumulation in 37 years is about $50 \mathrm{~m}(160 \mathrm{ft})$ and its estimated volume is about 8 million $\mathrm{m}^{3}\left(10\right.$ million $\left.\mathrm{yd}^{3}\right)$. The sediment distribution is shown in figure $21 \mathrm{c}$. In this hypothetical scenario, we consider that all these sediments might liquefy and slide into the bay. 


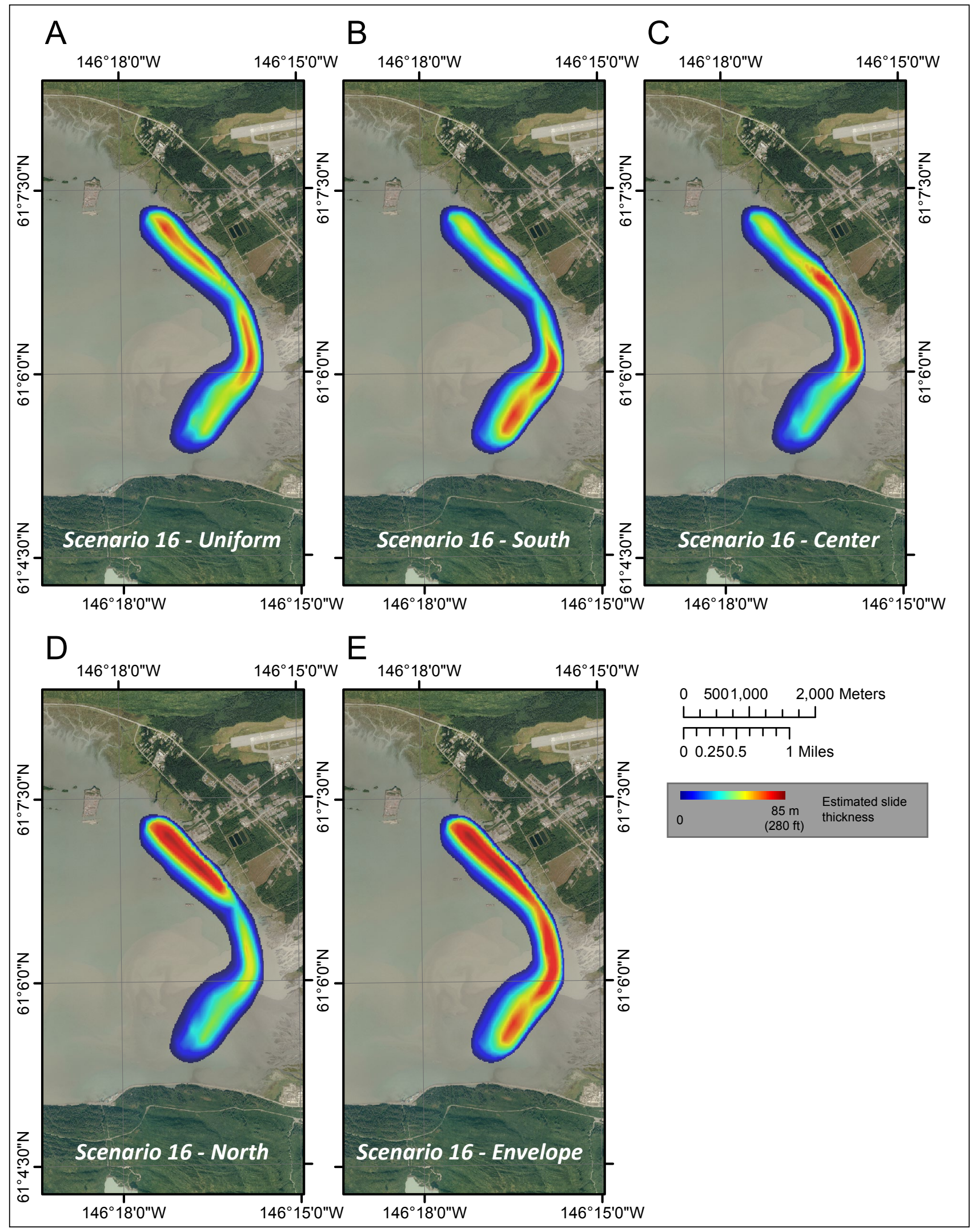

Figure 19. Illustrations showing initial thickness of the different realizations of the HPV landslide according to sub-scenarios of scenario 16. 


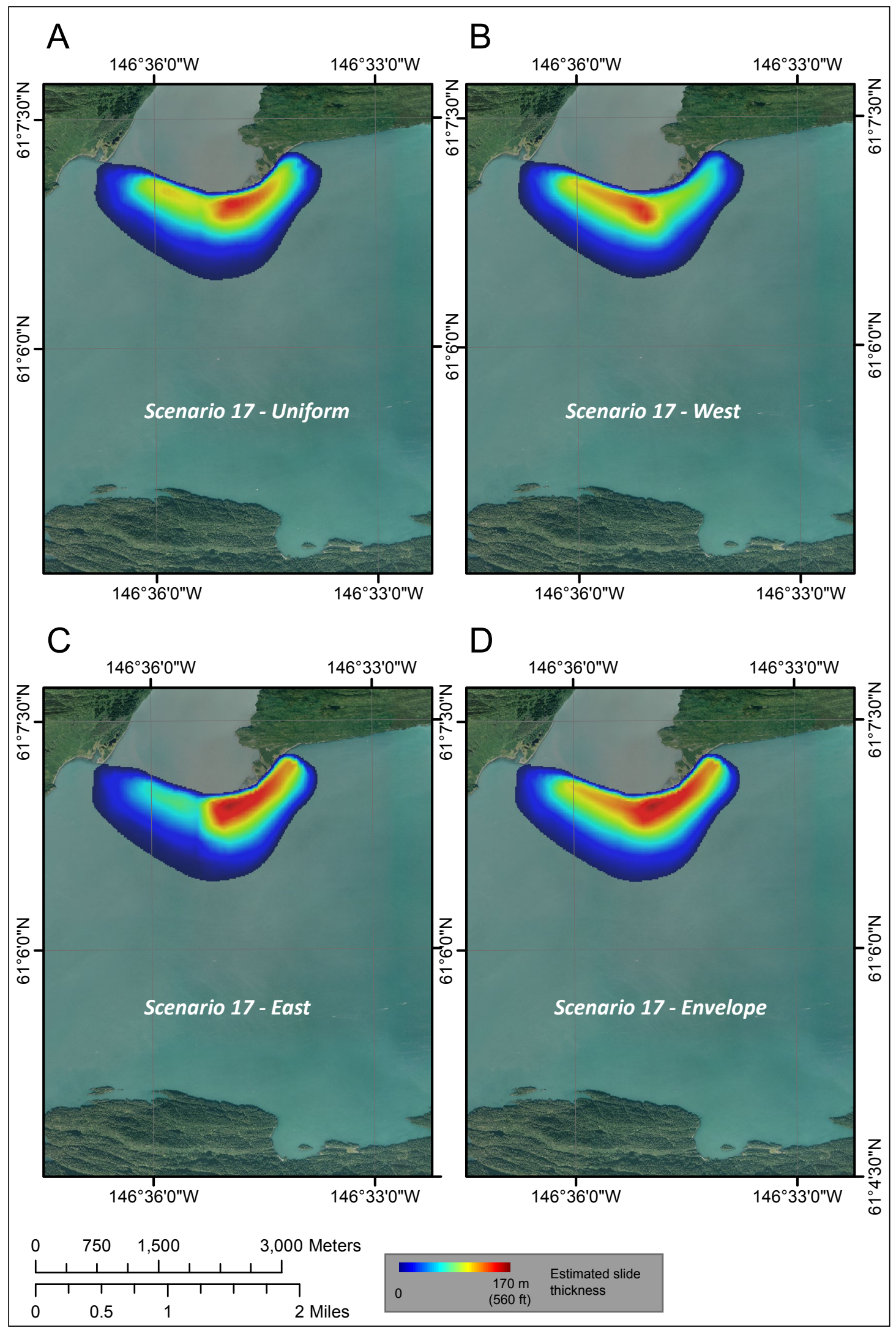

Figure 20. Illustrations showing initial thickness of the different realizations of the SBM landslide according to sub-scenarios of scenario 17. 


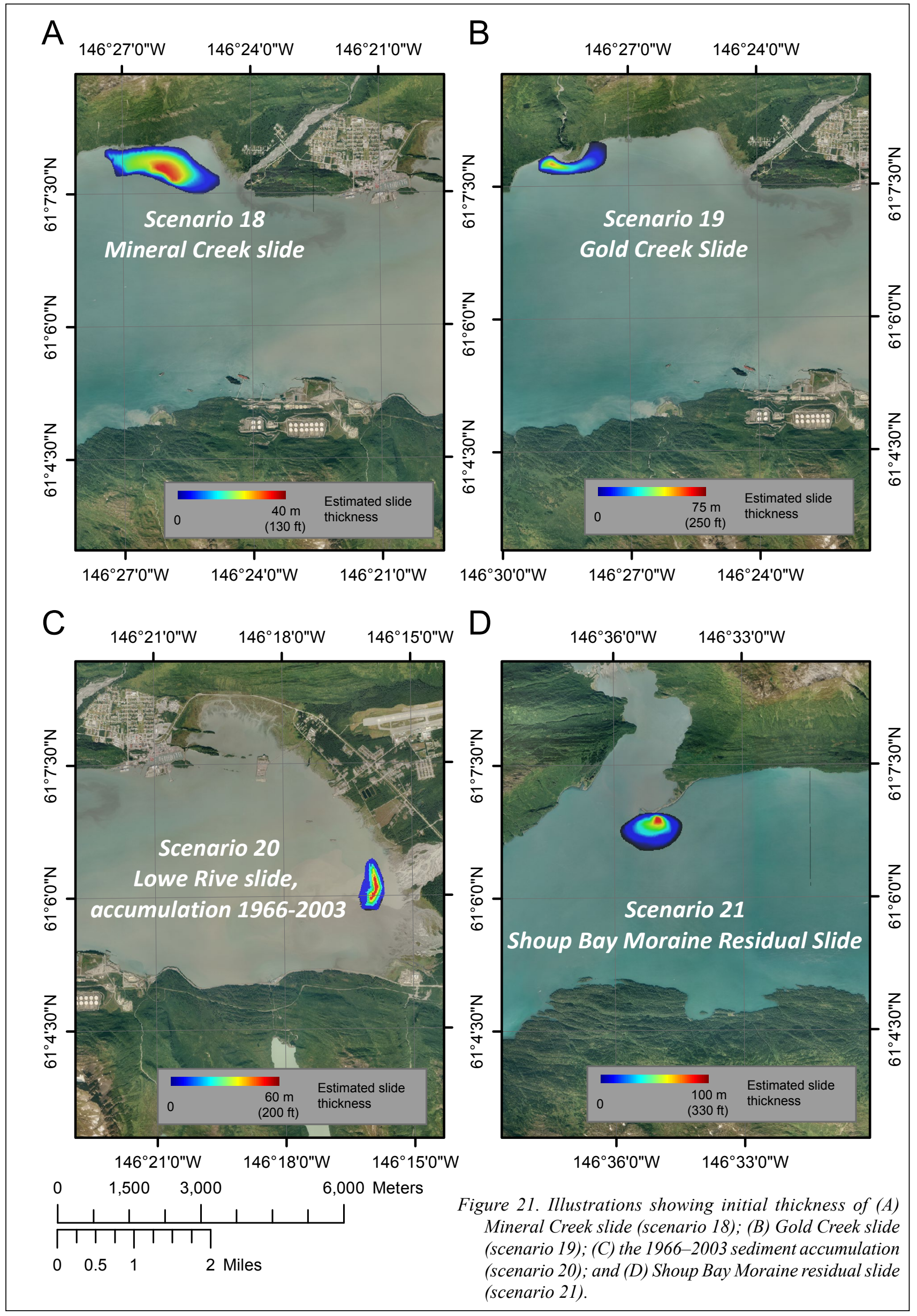


Scenario 21. Hypothetical event: An underwater slide at Shoup Bay moraine (SBM residual slide).

Strong ground shaking during the 1964 earthquake caused a massive slide at Shoup Bay moraine. However, some material was severely weakened and remained attached to a main body of the moraine on its slope. A close examination of the moraine slopes shows a possibly unstable block of sediments. Here, we hypothesize that this block might fail and slide into the port. The total volume of sediment is approximately 16 million $\mathrm{m}^{3}$ (21 million $\mathrm{yd}^{3}$ ). The SBM residual slide thickness and its location are shown in figure $21 \mathrm{~d}$.
Scenario 22. Hypothetical event: Simultaneous failure of underwater slide complexes described by scenarios 13-16 (Combined slide).

We assume that the slide-prone unconsolidated deposits described by envelope sub-scenarios of scenarios 13-16 are initially at rest, then are simultaneously triggered into sliding by ground shaking, and move thereafter only under the force of gravity. The total volume of sediments is approximately 270 million $\mathrm{m}^{3}$ (353 million $\left.\mathrm{yd}^{3}\right)$.

All scenarios are listed in table 3.

Table 3. All hypothetical scenarios used to model tsunami runup in Port Valdez.

\section{Tectonic Scenarios:}

\begin{tabular}{|c|c|c|}
\hline Scenario 1 & \multicolumn{2}{|c|}{ Repeat of the 1964 event, JDM } \\
\hline Scenario 2 & \multicolumn{2}{|c|}{ Repeat of the 1964 event, SDM } \\
\hline Scenario 3 & \multicolumn{2}{|c|}{ Multi-segment event based on the JDM } \\
\hline Scenario 4 & \multicolumn{2}{|c|}{ Multi-segment event based on the SDM } \\
\hline Scenario 5 & \multicolumn{2}{|c|}{ Rupture of the Yakutat-Yakataga segment } \\
\hline Scenario 6 & \multicolumn{2}{|c|}{ Rupture of the Cascadia zone } \\
\hline Scenario 7 & \multicolumn{2}{|c|}{ Rupture of the Prince William Sound asperity of the JDM } \\
\hline Scenario 8 & \multicolumn{2}{|c|}{ Rupture of the Kodiak Island asperity of the JDM } \\
\hline Scenario 9 & \multicolumn{2}{|c|}{ Rupture of the Prince William Sound asperity of the SDM } \\
\hline Scenario 10 & \multicolumn{2}{|c|}{ Rupture of the Kodiak Island asperity of the SDM } \\
\hline Scenario 11 & \multicolumn{2}{|c|}{ Modified multi-segment event: Rupture of the PWS and YY segments of the JDM } \\
\hline Scenario 12 & \multicolumn{2}{|c|}{ Modified multi-segment event: Rupture of the PWS and YY segment of the SDM } \\
\hline Scenario 13 & \multicolumn{2}{|c|}{$M_{w} 8.8$ earthquake in the Gulf of Alaska region: $17-30 \mathrm{~km}$, uniform slip along strike } \\
\hline Scenario 14 & \multicolumn{2}{|c|}{ Mw8.8 earthquake in the Gulf of Alaska region: $13-28 \mathrm{~km}$, variable slip along strike } \\
\hline Scenario 15 & \multicolumn{2}{|c|}{ Mw8.8 earthquake in the Gulf of Alaska region: $12-29 \mathrm{~km}$, variable slip along strike } \\
\hline \multicolumn{3}{|c|}{ Landslide Scenarios: } \\
\hline \multirow{6}{*}{ Scenario 16} & \multicolumn{2}{|c|}{$\begin{array}{l}\text { Repeat of the 1964-type event: An underwater slide at the head of Port Valdez (HPV slide) } \\
\text { Sub-scenarios for the main body of the slide: }\end{array}$} \\
\hline & Scenario 16-Uniform & Uniformly distributed along the at head of Port Valdez \\
\hline & Scenario 16 -North & Located at the northeastern segment of the head of the port \\
\hline & Scenario 16 - Center & Located at the center-eastern segment of the head of the port \\
\hline & Scenario 16-South & Located at the southeastern segment of the head of the port \\
\hline & Scenario 16-Envelope & Maximum slide thickness among all sub-scenarios \\
\hline \multirow{5}{*}{ Scenario 17} & \multicolumn{2}{|c|}{$\begin{array}{l}\text { Repeat of the 1964-type event: An underwater slide at Shoup Bay moraine (SBM slide) } \\
\text { Sub-scenarios for the main body of the slide: }\end{array}$} \\
\hline & Scenario 17-Uniform & Uniformly distributed along the Shoup Bay moraine \\
\hline & Scenario 17 -East & Located at the eastern part of the moraine \\
\hline & Scenario 17 -West & Located at the western part of the moraine \\
\hline & Scenario 17-Envelope & Maximum slide thickness among all sub-scenarios \\
\hline Scenario 18 & \multicolumn{2}{|c|}{ An underwater slide offshore of Mineral Creek (MC slide). } \\
\hline Scenario 19 & \multicolumn{2}{|c|}{ An underwater slide offshore of Gold Creek (GC slide). } \\
\hline Scenario 20 & \multicolumn{2}{|c|}{ An underwater slide offshore of Lowe River (LR slide) } \\
\hline Scenario 21 & \multicolumn{2}{|c|}{ An underwater slide at Shoup Bay moraine (SBM residual slide) } \\
\hline Scenario 22 & \multicolumn{2}{|c|}{ Simultaneous failure of underwater slide complexes described by scenarios 16-19 (Combined slide) } \\
\hline
\end{tabular}




\section{MODELING RESULTS}

\section{Numerical Modeling of the 1964 Tsunami in Port Valdez: Model Verification}

In this section, we compare inundation modeling results of the 1964 tsunami in Port Valdez with the eyewitness reports and the observed extent of the inundation. To model the inundation of coastal areas in Port Valdez, we use a series of nested grids. Recall that the lowest resolution 2-arc-minute grid spans the Gulf of Alaska, while the finest resolution $15 \mathrm{~m}$ (49.2 ft) grid covers Port Valdez. We use the developed high-resolution $\mathrm{DEM}_{64}$ that incorporates the post-earthquake bathymetry and topography near the old townsite, as described earlier in this report. The reconstructed Shoup Bay $\left(\mathrm{SBM}_{64}\right)$ slide and old town $\left(\mathrm{HPV}_{64}\right)$ slide configurations, as well as the pre- and post-earthquake MLLW shorelines, are shown in figures $8 \mathrm{a}$ and $8 \mathrm{~b}$, respectively.

\section{Modeling the Landslide-Generated Tsunami at the Old Town Waterfront}

According to Coulter and Migliaccio, (1966), the predicted low tide for March 27, 1964, was -0.18 m (-0.6 ft) above the MLLW level at 6:19 p.m., and the predicted high tide for March 28 was $3.78 \mathrm{~m}$ (12.4 ft) above the MLLW level at 12:42 a.m. Thus, we estimate that at the time of the main shock the water level was near the MLLW (Kachadoorian, 1965). A sketch of the water level in Port Valdez just before the earthquake is shown in figure 22a. During the earthquake,

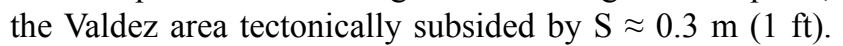
Considering that the epicenter was about $60 \mathrm{~km}(37 \mathrm{mi})$ away from Port Valdez, and that the rupture velocity was around $3 \mathrm{~km} / \mathrm{s}(1.9 \mathrm{mi} / \mathrm{s})$, it seems likely the major vertical subsidence was coeval with passage of the rupture beneath the area, about 20-30 seconds after the earthquake began. We thus assume that the subsidence occurred within a few seconds after the main shock. Local compaction-related subsidence along the waterfront was measured up to $3.0 \mathrm{~m}$ (10 ft) by Coulter and Migliaccio, (1966, plate 2) and was incorporated into $\mathrm{DEM}_{64}$. A sketch of the Valdez harbor and landslide-generated tsunami during the earthquake is shown in figure 22b. To reconstruct the sea level at Valdez after the earthquake but before arrival of the tectonic tsunami, we first convert the developed $\mathrm{DEM}_{64}$ from the post-earthquake MHHW datum to the pre-earthquake MHHW datum by adding the tectonic subsidence $S$, figure $22 \mathrm{c}$. Then we set sea level in the converted DEM ${ }_{64}$ to the MLLW level ${ }^{8}$.

We assume that the slide-prone unconsolidated deposits at the old townsite and Shoup Bay are initially at rest and were triggered into sliding by ground shaking. The slide material moves after the ground shaking only under the force of gravity. Shannon and Hilts (1973) conducted a subsurface geotechnical investigation of materials that failed in settings similar to Resurrection Bay, Alaska, during the 1964 earthquake, and found that the density of the slide material ranged from $2,000 \mathrm{~kg} / \mathrm{m}^{3}$ to $2,110 \mathrm{~kg} / \mathrm{m}^{3}\left(125 \mathrm{lb} / \mathrm{ft}^{3}\right.$ to $\left.132 \mathrm{lb} / \mathrm{ft}^{3}\right)$. Unfortunately, there are no measurements of the slide viscosity, but sensitivity studies by Rabinovich and others (2003) demonstrate that the influence of kinematic viscosity on tsunami heights is not significant. We assume slide density of $\rho=2,000 \mathrm{~kg} / \mathrm{m}^{3}\left(125 \mathrm{lb} / \mathrm{ft}^{3}\right)$ and slide kinematic viscosity of $\mu_{\mathrm{k}}=0.05 \mathrm{~m}^{2} / \mathrm{s}\left(0.54 \mathrm{ft}^{2} / \mathrm{s}\right)$. At the open boundary of the numerical grid near Valdez Arm, we specify the radiation boundary condition for the water waves. We numerically model triggering of the landslide and simulate the landslidegenerated tsunamis in Port Valdez for 15 minutes with a 0.01 second time step.

${ }^{8}$ The tidal range at Valdez is $3.7 \mathrm{~m}(12.1 \mathrm{ft})$ from MHHW to MLLW. In this work the change in the MLLW datum as well as the postseismic rebound in Valdez were assumed to be negligibly small. We also note that in Whittier at the time of earthquake the sea level

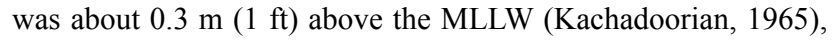
probably due to some synoptic activity. Therefore, the tide in Valdez during the earthquake could have been anywhere between 0 and $0.3 \mathrm{~m}(0$ and $1 \mathrm{ft})$.

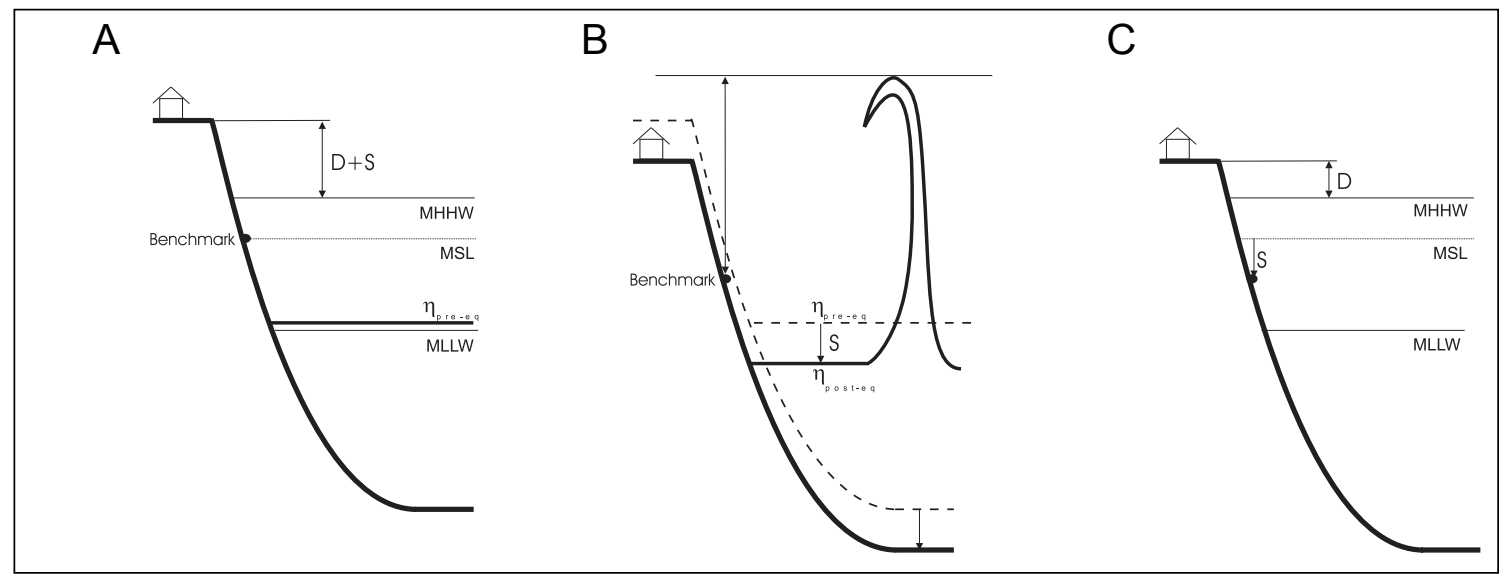

Figure 22. Schematic drawing of the city harbor (A) before the 1964 earthquake; (B) after the earthquake and during the landslide-generated tsunami; and $(C)$ at present. $S=$ coseismic subsidence; $D=$ elevation of harbor parking with respect to the MHHW; $\eta=$ water level at the time of the 1964 earthquake. 
We simulate waves generated only by the $\mathrm{HPV}_{64}$ slide; the modeled inundation is shown in figure 23. The observed extent of the inundation after the 1964 earthquake is shown by the solid yellow line. Note that the 1964 tsunami inundated along the streets, but did not flood inside of the city blocks. We note that the following comparison of the modeled and observed extents of inundation is hindered by high snow berms in the town and deep consolidated snow cover at the time of the earthquake. The berms could have channeled the water and restricted its distribution (Coulter and Migliaccio, 1966). The dry 'islands' in the inundation zone are marked by the line with hachures pointing into the inundated area. The yellow line probably encompasses the composite inundation by both the landslide-generated and tectonic tsunamis. The debris line from the first wave is shown in solid violet. We note that many buildings either collapsed or disintegrated when they were struck by the first wave, hence the debris could have been primarily composed of the coarse construction material, as shown in photographs in Wilson and Tørum (1972). We speculate that water carried by the first wave probably flooded beyond the debris line. The latter is confirmed by Coulter and Migliaccio (1966), who stated that the first wave reached McKinley Street, but did not flood beyond it except for a few locations. Thus, the debris line could not be directly used to calibrate the modeling results.

The modeling results presented in figure 23 reveal that the extent of the simulated tsunami inundation is sensitive to parameterization of the bottom drag coefficient, that is, the surface roughness coefficient $\mu$ in the Manning formula (Nicolsky and others, 2011). The maximum modeled tsunami inundation for three values of the surface roughness, $\mu=0.01$, $0.02 \mathrm{~m}^{1 / 3} / \mathrm{s}\left(0.015,0.03 \mathrm{ft}^{1 / 3} / \mathrm{s}\right)$, and $0.03 \mathrm{~m}^{1 / 3} / \mathrm{s}\left(0.045 \mathrm{ft}^{1 / 3} / \mathrm{s}\right)$, are plotted by solid red, green, and blue lines, respectively. The best comparison with observations is obtained when the roughness $\mu$ is equal to $0.01 \mathrm{~m}^{1 / 3} / \mathrm{s}\left(0.015 \mathrm{ft}^{1 / 3} / \mathrm{s}\right)$, which corresponds to the roughness of smooth metal (Linsley and Franzini, 1979). A second good comparison is related to $\mu=0.02 \mathrm{~m}^{1 / 3} / \mathrm{s}\left(0.03 \mathrm{ft}^{1 / 3} / \mathrm{s}\right)$ that corresponds to firm gravel. Since the best match corresponds to the surface roughness $\mu=0.01 \mathrm{~m}^{1 / 3} / \mathrm{s}\left(0.015 \mathrm{ft}^{1 / 3} / \mathrm{s}\right)$, the remainder of this report uses this value to compare the modeling results with observations as well as to calculate the tsunami inundation due to all hypothetical landslides.

In figure 24, the modeling results show the modeled runup distribution of the two landslide-generated tsunamis. The $\mathrm{HPV}_{64}$ slide-generated tsunami (fig. 24A) causes significant runup near Jackson Point and the oil terminal, whereas inundation by the $\mathrm{SBM}_{64}$ slide-generated tsunami (fig. 24B) is localized at the western part of Port Valdez near Anderson Bay. Taking into account that the $\mathrm{SBM}_{64}$ slide configuration is approximated by the bathymetry difference maps, which do not provide a complete coverage of the submerged moraine, the modeling results show a good comparison with observations in Anderson Bay (Plafker and others, 1969). The modeled runup ranges between $30 \mathrm{~m}(100 \mathrm{ft})$ and $45 \mathrm{~m}$ $(150 \mathrm{ft})$ above sea level, although Plafker and others (1969) reported the runup in the range of 17-24 $\mathrm{m}(55-80 \mathrm{ft})$ above sea level.
On the opposite shore, near the Cliff Mine, just east of the Shoup Bay moraine, the modeled runup compares relatively well with the observations. At this location, the modeled runup is about $30 \mathrm{~m}(100 \mathrm{ft})$, whereas the reported wave reached an elevation of $52 \mathrm{~m}(170 \mathrm{ft})$. Thus, the modeled runup around Anderson Bay is overestimated, while the runup near the Cliff Mine is underestimated. The difference could be explained by inaccuracies in the assumed $\mathrm{SBM}_{64}$ slide configuration. The true $\mathrm{SBM}_{64}$ slide geometry is unknown, and a more accurate reconstruction is hampered by poor quality pre-1964 bathymetry near the Cliff Mine. Also, simplifications of the slide rheology may have resulted in the quantitative disagreement of the modeled and observed runup. The collapse and sliding of large blocks (up to $80 \mathrm{~m}$ [262 ft] tall) is approximated by sliding of the viscous-elastic ground material. Despite these limitations, our model produces large run-ups where observed after the 1964 earthquake.

Time series of the modeled water wave height at three locations in the old city waterfront along Alaska Avenue are shown in the top three panels in figure 25 . The locations are at reference points 37,38 , and 39 shown in figure 23 . In all panels, the wave heights related to the $\mathrm{HPV}_{64}$ and $\mathrm{SBM}_{64}$ slides are plotted by green and red lines, respectively. We note that in the numerical experiment the initial motion of the $\mathrm{HPV}_{64}$ slide first caused withdrawal of water offshore from the old harbor (point 37). The top plot shows that the water level decreased by about $8 \mathrm{~m}(26 \mathrm{ft})$ and later surged upward as much as $6 \mathrm{~m}(20 \mathrm{ft})$ above the pre-earthquake sea level in the course of self-leveling. At other locations offshore from the old townsite, similar water dynamics were simulated: A drawdown by about $8-10 \mathrm{~m}(26-33 \mathrm{ft})$ accompanied later by 5-7 m (16-23 ft) surge above the pre-earthquake sea level. The computer simulation qualitatively reproduces the waves that caused gyrations of the freighter, the M/V Chena, which was offloading at the Valdez dock during the 1964 event. For example, the modeling captures an observed wave that lifted the ship 6-10 m (20-33 ft). An in-depth study of the $\mathrm{M} / \mathrm{V}$ Chena dynamics and trajectory was provided by Wilson and Tørum (1972), but modeling the ship dynamics is out of scope of this report. The water dynamics at point 38 show

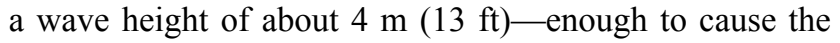
destruction of the dock facilities and cannery, as reported by eyewitnesses. Finally, we mention that the simulated wave from the collapse of the $\mathrm{HPV}_{64}$ slide reaches up to point 39, at the intersection of Alaska Avenue and McKinley Street, but barely floods beyond it.

In another numerical experiment, a first wave due to the failure of the $\mathrm{SBM}_{64}$ slide traverses Port Valdez and arrives to the old town waterfront about 6 minutes after its generation. Upon arrival, the wave is greatly attenuated and floods only a little beyond Water Street. The computed inundation line is shown in figure 23 as an orange line.

Finally, we model the case when the $\mathrm{HPV}_{64}$ and $\mathrm{SBM}_{64}$ slides occur simultaneously. Although it is possible that individual slides were triggered at different times during or after the ground shaking, there is no evidence either to support or to reject this hypothesis. However, given the severity of ground shaking, it is highly probable that both slides failed 


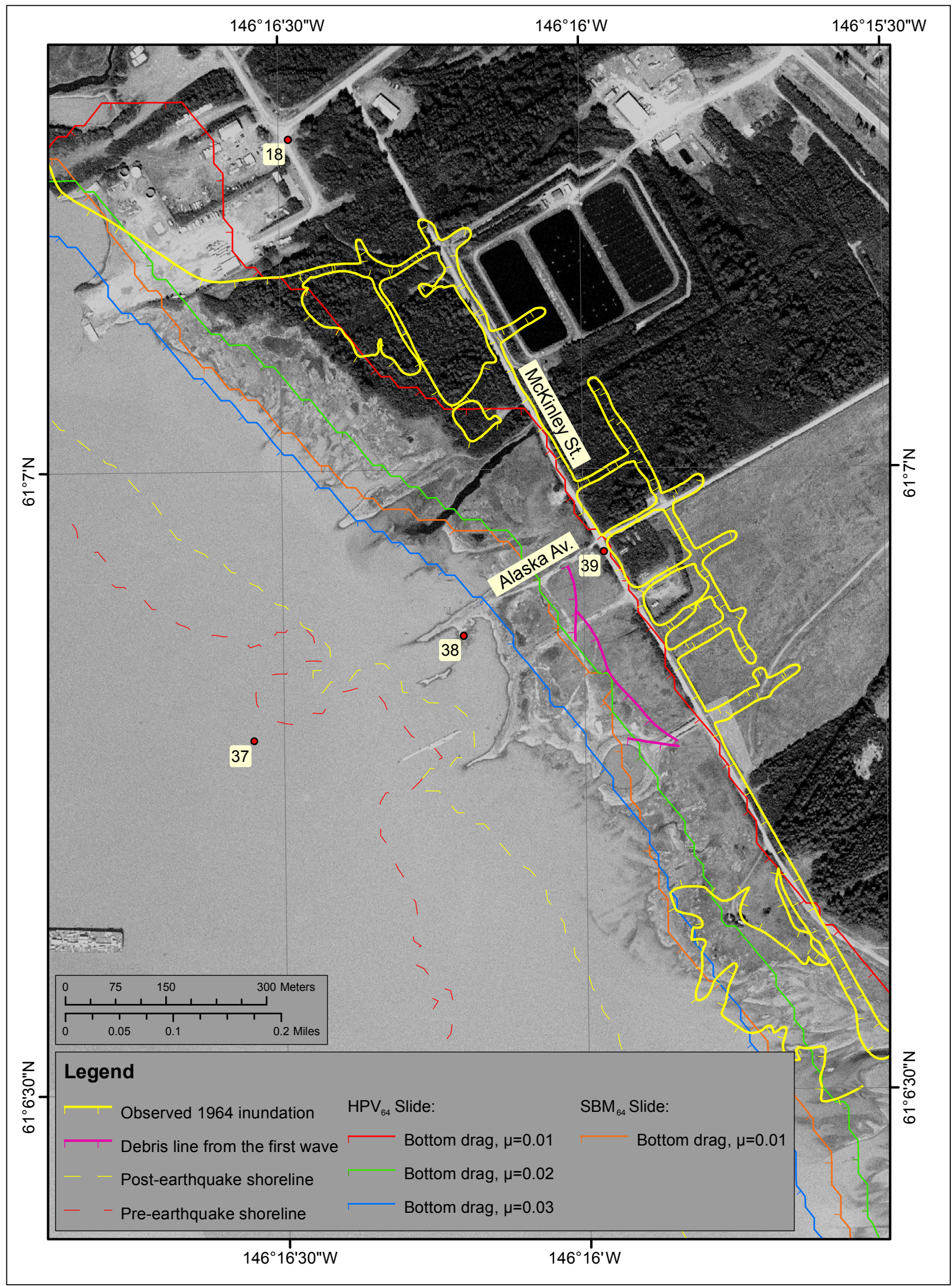

Figure 23. Sensitivity of inundation by the HPV ${ }_{64}$ slide-generated tsunami in the old townsite with respect to the parameterization of the bottom drag. The yellow line represents observed inundation in 1964 caused by both the landslide-and tectonically-generated tsunamis. The modeled MLLW shoreline before the earthquake is shown by a dashed yellow line. Hachures indicate the water side of the inundation lines. 


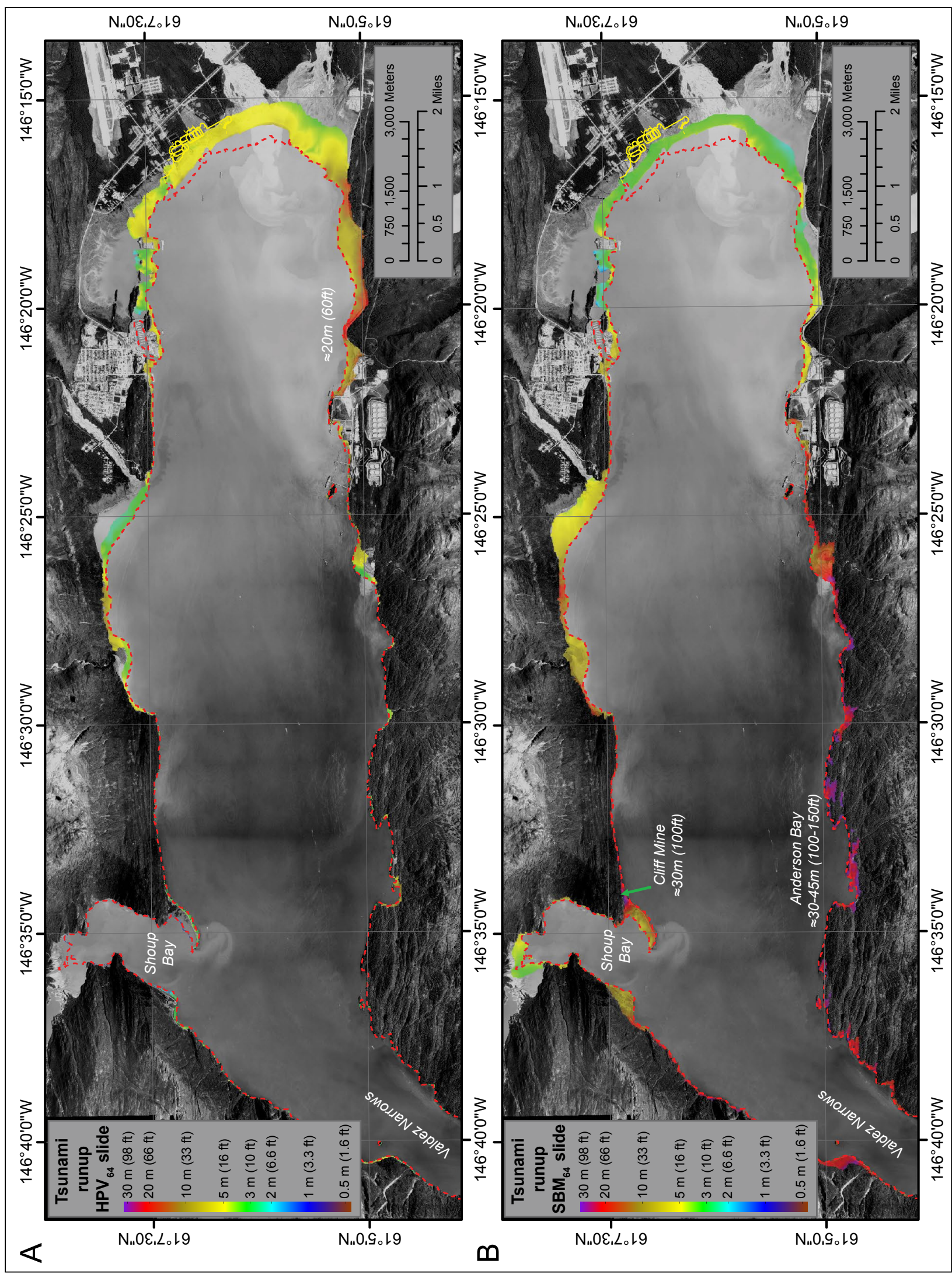

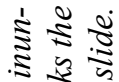

का के

के 촌

ป๊

$50 \div 5$

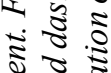

वे ๘ँ

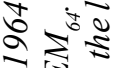

농 농

of 03

: 00 :

ำ

N \& 8

₹ :

ปิ

$2 \approx 5$

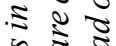

औ 8

इำ

施

ग 5

2.

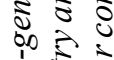

ปิ

जิ

2.

ผै है

(1)

$x=2$

ह เ

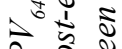

ลे

इ)

उ.

उ है ₹

क्ष

वิ ะี

$3 \sqrt{2} \frac{2}{2}$

초욜

क 3

ㄴำ

空

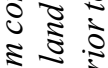

폴

है

ริ

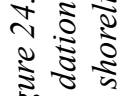




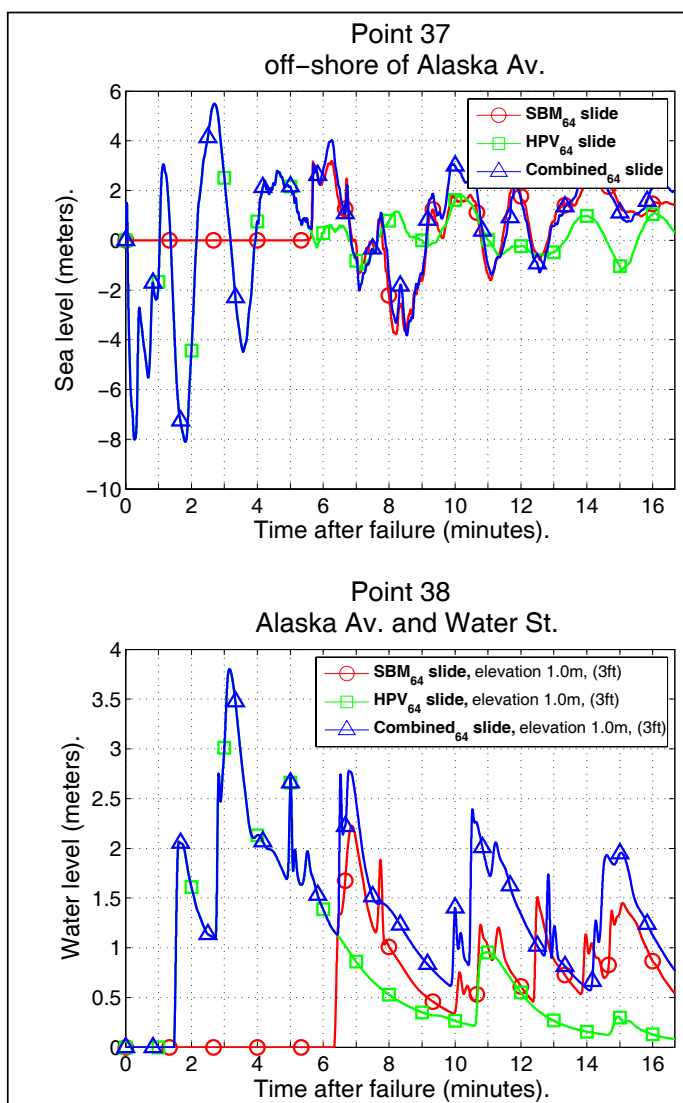

Point 39

Alaska Av. and McKinley St.

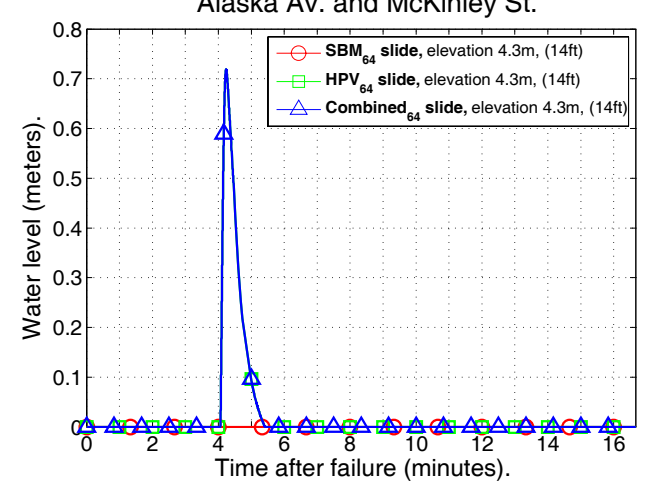

Point 36

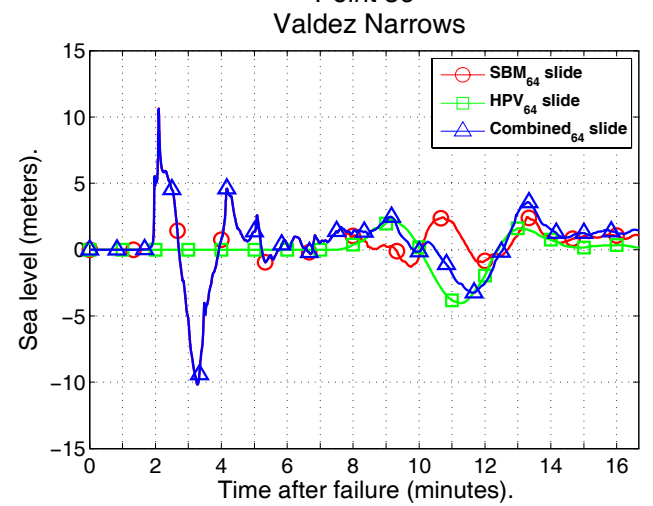

Point 37

off-shore of Alaska Av.

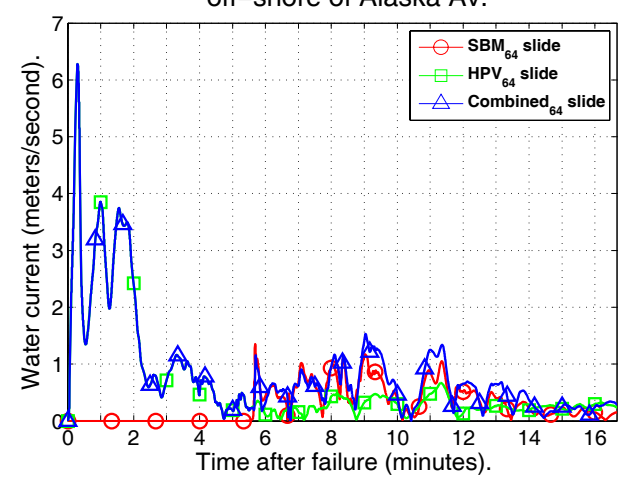

Point 38

Alaska Av. and Water St.

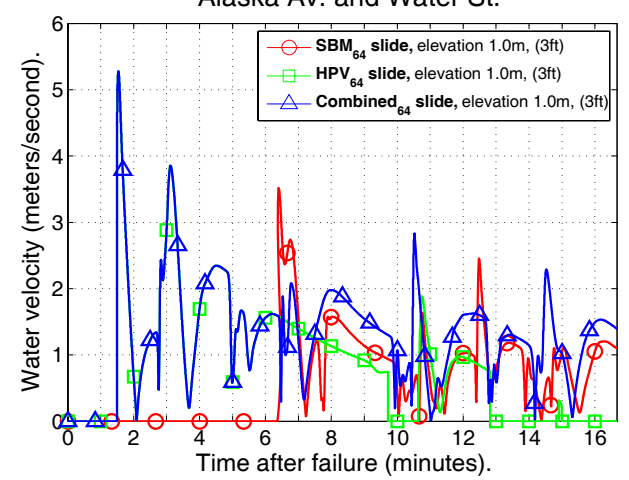

Point 39

Alaska Av. and McKinley St.

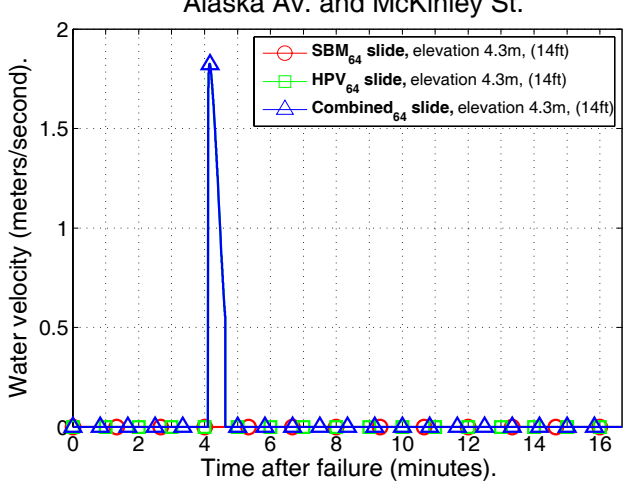

Point 36

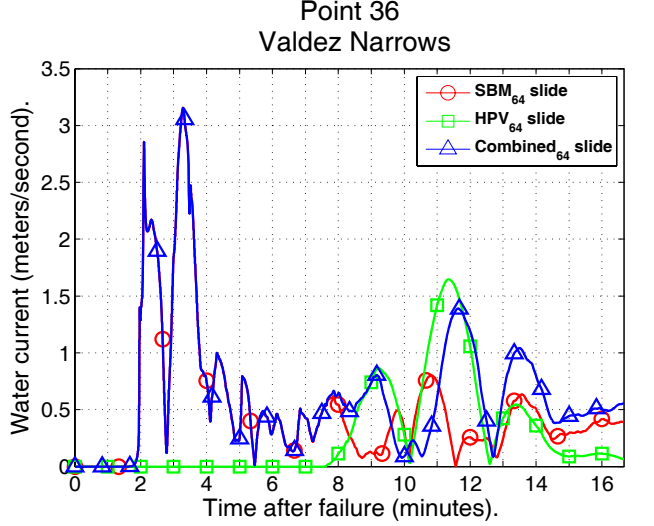

Figure 25. TOP THREE PAIRS: Modeled water level above ground at points 37, 38, and 39 along Alaska Avenue (figure A-1 shows locations) during the 1964 tsunami. Bоттом PAIR: Modeled water-level dynamics at point 36, in Valdez Narrows. The level is in meters with respect to the post-earthquake MLLW datum. 
simultaneously (H. Fritz, Georgia Institute of Technology, oral commun., 2011). Figure 25 uses a blue line to show the simulated wave height due the simultaneous failure of the two slides. The extent of the inundation caused by Combined ${ }_{64}$ slide (simultaneous failure of the $\mathrm{HPV}_{64}$ and $\mathrm{SBM}_{64}$ slides) near the old townsite is the same as the inundation extent by the $\mathrm{HPV}_{64}$ slide alone.

Near the old town, the modeled wave dynamics caused by the simultaneous failure differ from the $\mathrm{HPV}_{64}$ slidegenerated water dynamics 6 minutes after the slide triggering, which is the time for waves generated by the $\mathrm{SBM}_{64}$ slide to arrive at the old town. In the simultaneous slide failure case, waves generated by the $\mathrm{HPV}_{64}$ and $\mathrm{SBM}_{64}$ slides combine in a complicated mutual canceling and amplifying phenomenon. Recall that according to the eyewitness reports the second wave hit the waterfront about 10 minutes after the first one and was a little smaller than the first wave. Our numerical simulations do not provide clear indications of the so-called second wave. It is possible that the slides did not occur simultaneously, or the modeled slide dynamics do not accurately capture the actual course of events. In this case, the model provides an inaccurate superposition of the waves that differs from the observations, and it cannot reproduce the second wave in the absence of the temporal decay between the slide triggerings. For example, a small temporal delay in the landslide triggering can change the superposition of waves and also modify their non-linear interference. It is possible that the $\mathrm{SBM}_{64}$ slide initiated approximately 4 minutes after the $\mathrm{HPV}_{64}$ slide, which would cause the initial $\mathrm{SBM}_{64}$ wave arrival at the time of a late-arriving $\mathrm{HPV}_{64}$ wave crest, that is, around 10-11 minutes after the collapse of $\mathrm{HPV}_{64}$ slide. Unfortunately, the timing of future landslide failure is unknown and additional research of this subject is necessary.

The bottom plot in figure 25 shows the water level near the navigation light at the entrance to Valdez Arm (Valdez Narrows). The location of the light is shown in figure 2. Prior to the tsunami, the light was standing on a concrete pylon

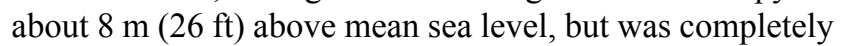
destroyed. The modeled wave height at the light location is about $10 \mathrm{~m}(33 \mathrm{ft})$ with a computed speed of approximately $3 \mathrm{~m} / \mathrm{s}(10 \mathrm{ft} / \mathrm{s})$. These values are sufficient to severely damage or carry away the light assembly. Recall that the wave outgoing from Port Valdez through Valdez Arm was observed by two eyewitnesses near Potato Point. They reported seeing the wave building up approximately 5 minutes after the earthquake and then 2 minutes later the wave overtopped the navigational light (Wilson and Tørum, 1972). Since the wave build-up is associated with a progressing mass failure, these eyewitness accounts appear to strengthen the hypothesis - the initiation of the $\mathrm{SBM}_{64}$ slide could be delayed with respect to an onset of the earthquake by 3-5 minutes-however there is no solid evidence to support or reject this hypothesis. The computed water dynamics at point 36 show that the simulated wave exits Port Valdez 2-3 minutes after the initiation of the $\mathrm{SBM}_{64}$ slide motion, which generates the initial wave build-up. We thus conclude that the simulated arrival of the wave to the lighthouse location is in agreement with the fishermen's observations.

\section{Modeling the Tectonic Tsunami at the Old Town Waterfront}

The residents of Valdez noticed erratic waves throughout the evening, but only two waves significantly flooded the city at night during the high tide. The most likely times of their arrival, according to Wilson and Tørum (1972, p. 451), are at 23:45 and 01:35. Therefore, we call these ' $23: 45$ ' and ' $01: 35$ ' waves, respectively. It was hypothesized that ' $23: 45$ ' and ' $01: 35$ ' waves are remnants of the greatly attenuated tectonic tsunami superimposed with a high tide (Wilson and Tørum, 1972). In this sub-section, we discuss our simulation of the 1964 tectonic tsunami and try to model the observed waves in Port Valdez.

First we note that the 1964 tsunami was generated in the Gulf of Alaska. Preliminary computations show that it takes approximately 45-60 minutes for a tsunami generated in the Gulf of Alaska to travel to Valdez. Since the source of local waves in Port Valdez ceased shortly after the end of ground shaking, we assume that the landslide-generated and tectonic tsunamis can be considered independent events, and hence modeled separately.

Since the 1964 earthquake occurred when the tide in Port Valdez was near MLLW, but the damaging '23:45' and '01:35' waves arrived on high tide, an interaction of the astronomic tide with the tectonic tsunami can be important. Unfortunately, the current numerical model does not simulate a periodic change of sea level due to tides. Since the sea level change due to the astronomic tides is a relatively slow process compared to the rapid sea level variations due to the tsunami, it is possible to decouple these two processes. As Port Valdez is connected to the Prince William Sound by the deep Valdez Narrows, the nonlinear interaction of the tsunami and tides could be assumed small in Port Valdez. Interested readers are referred to Kowalik and others (2006) and Kowalik and Proshutinsky (2010) for a fruitful discussion of the tsunami-tide interaction. We thus resort to simulation of the 1964 tsunami without tidal forcing, and then superimpose the computed tsunami with the tide in Port Valdez. For a reason discussed later in the text, we model the tsunami inundation in the old townsite using the $\mathrm{DEM}_{64}$, whose vertical datum is set to the MHHW level.

We model the water dynamics offshore from the old town and show the water level according to scenarios 1 and 2, associated with the JDM and SDM, respectively, in figure 26a. The water level is computed with respect to the MHHW tide level. The maximum computed wave heights, without a tidal correction, are about $3.0 \mathrm{~m}(10 \mathrm{ft})$ and $2.0 \mathrm{~m}(7 \mathrm{ft})$ according to the JDM and SDM, respectively. Note that the simulated strong oscillations continue for about 6 hours, but sharply subdue after midnight. Moreover, the maximum height of the waves rarely reaches above $1.0 \mathrm{~m}(3 \mathrm{ft})$ after midnight. In the same figure, we use a green line to show the reconstructed tide level dynamics.

The superposition of the modeled tsunami and reconstructed tide dynamics offshore of the waterfront is shown in figure 26b. In the computer experiment, only three waves between 21:00 and 01:00 surpass the MHHW level. The timing of the first event roughly corresponds to the follow- 
ing observation. At 21:00, the withdrawal of water left $\mathrm{M} / \mathrm{V}$ Falcon beached, then at 21:30 a high wave reached up to Water Street on Alaska Avenue (Wilson and Tørum, 1972, p. 453). This suggests that the modeled crest at 23:00 and the one shortly after $24: 00$ correspond to the ' $23: 45$ ' and ' $01: 35$ ' waves, respectively. We thus conclude that even with some simplifications in the tsunami-tide modeling, the numerical results for both deformation models (JDM and SDM) agree with the eyewitness accounts.

Figure 27a shows the modeled water depth at McKinley Street on Alaska Avenue for the first 11 hours after the earthquake. Water levels modeled according to the JDM and SDM are plotted by red and blue lines, respectively, and the tide level, as before, is marked by the green line. The plot shows that there are five distinct flooding events before midnight. In the computer experiment, the tsunami progresses on the fixed tide level corresponding to the MHHW level. Since the tide level was supposed to be much lower between 18:00 and 21:00, the simulated flooding in this time interval is considered to be fictitious. We correct the water depth by adding the tide signal, and thus obtain more realistic water depth dynamics. The adjusted water levels are plotted in figure $27 \mathrm{~b}$. Note that there are only two or three occasions when inundation of McKinley Street occurs, according to the SDM/JDM. The modeled heights of the '23:45' and '01:35' waves on McKinley Street according to the SDM are $0.5 \mathrm{~m}$ $(1.6 \mathrm{ft})$ and $1.5 \mathrm{~m}(5 \mathrm{ft})$, respectively. These numerical results are in good agreement with the observations that report $0.75 \mathrm{~m}(2.5 \mathrm{ft})$ and $1.5-1.8 \mathrm{~m}(4.9-5.9 \mathrm{ft})$ in buildings along McKinley Street, respectively (Wilson and Tørum, 1972, p. 451). The numerical results according to the JDM show some positive bias.

Finally, in figure 28 we depict extents of the simulated tsunami inundation calculated both for the JDM and SDM tectonic sources as well as for the simultaneous $\mathrm{HPV}_{64}$ and $\mathrm{SBM}_{64}$ slide failure case (Combined ${ }_{64}$ slide). The simulated inundation extent due to the landslide-generated tsunami is marked by the red hachured line, while those simulated

A

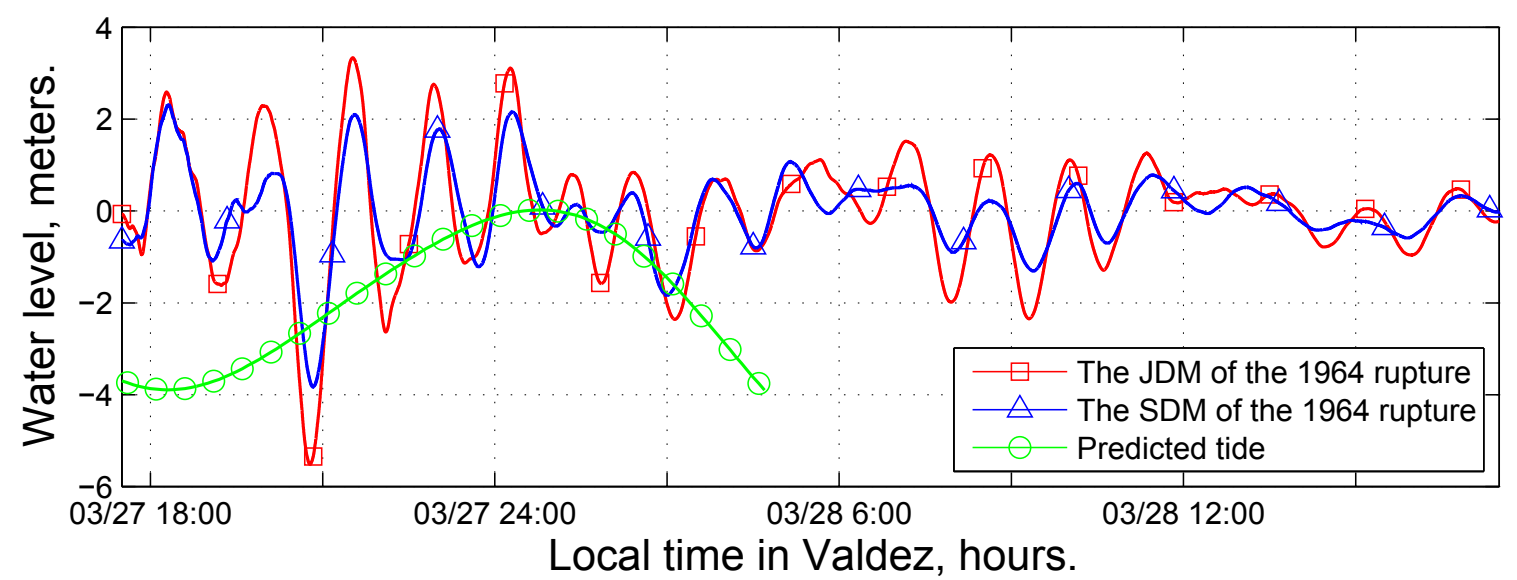

$\mathrm{B}$

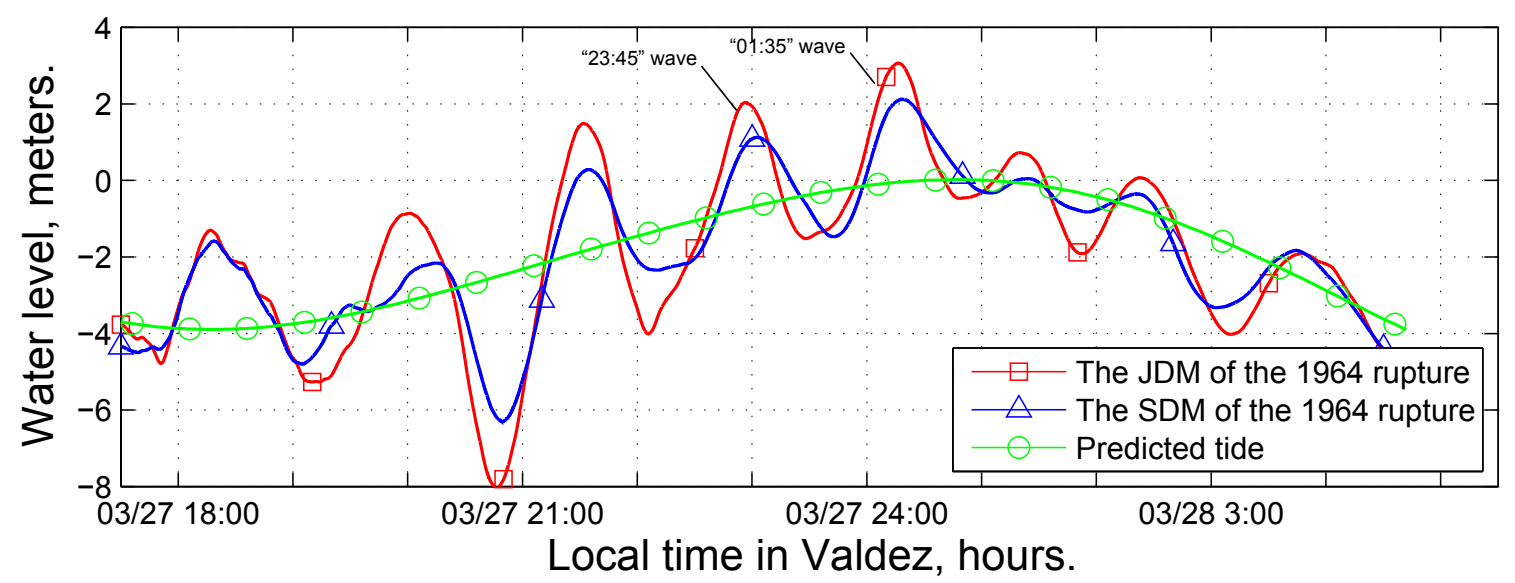

Figure 26.(A) Reconstructed tide level and modeled water-level dynamics at point 37 (figure A-1 shows locations) during the 1964 tectonic tsunami, based on the SDM and JDM. (B) Tide-corrected simulated water level at point 37. On both panels, the water level is in meters with respect to the post-earthquake MHHW datum. 
A

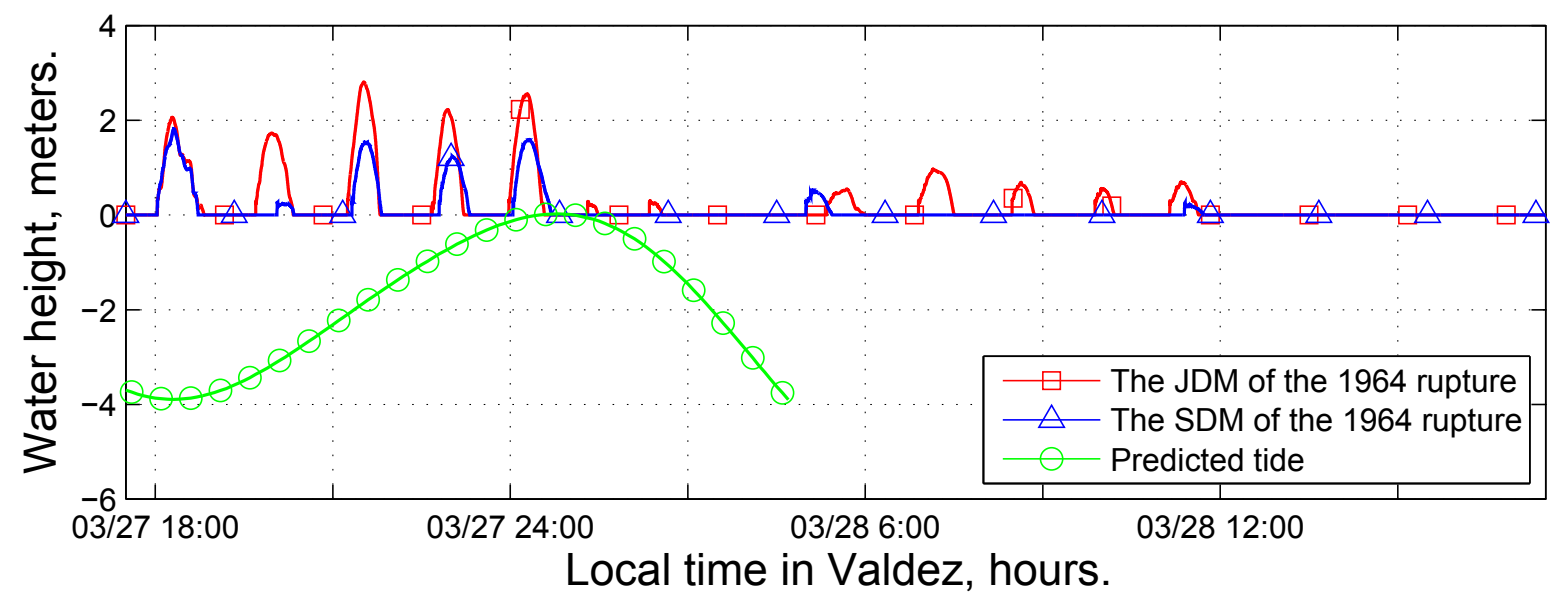

B

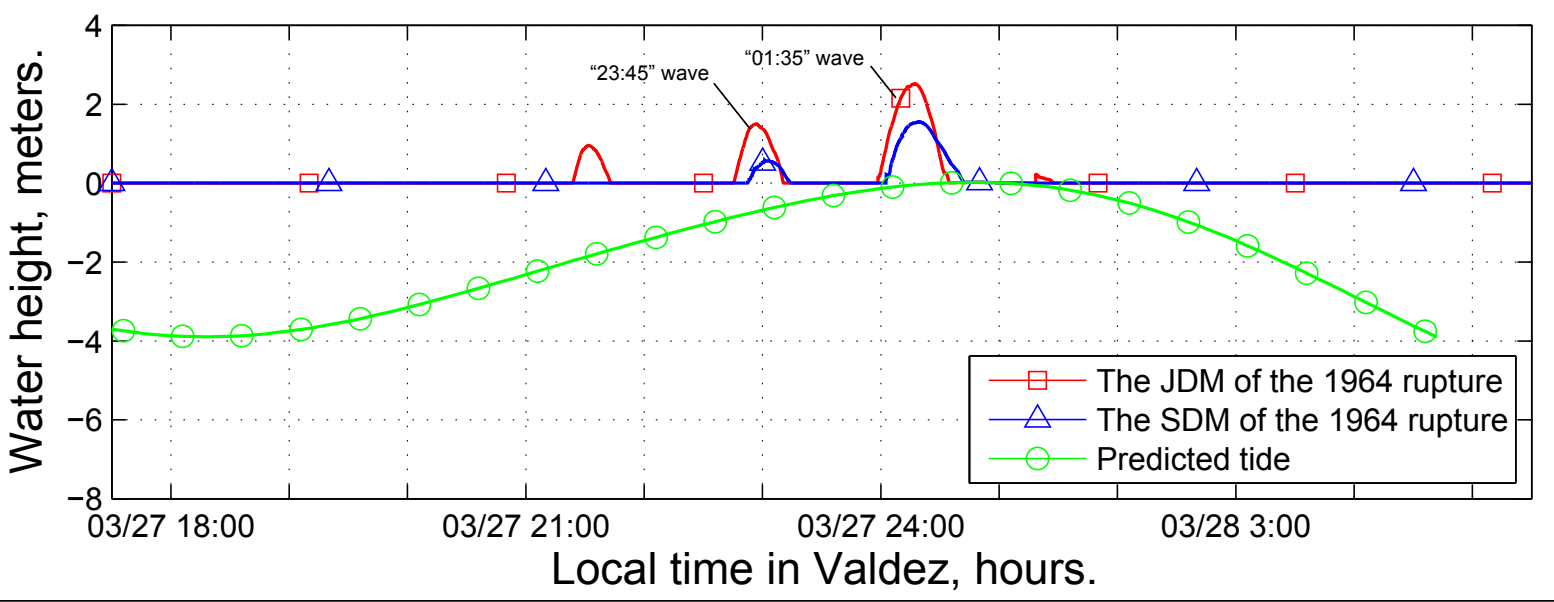

Figure 27. (A) Reconstructed tide level and modeled water depth at point 39 (figure A-1 shows locations) during the 1964 tectonic tsunami, based on the SDM and JDM. (B) Tide-corrected simulated water depth at point 39. On both panels, the water level is in meters with respect to the post-earthquake MHHW datum.

according to the JDM and SDM are plotted by green and blue hachured lines, respectively. The observed 1964 inundation zone is shown by a yellow line. Before comparing the modeled results to the observations we note that in the actual course of events, the '01:35' wave arrived at Valdez on the MHHW tide level and produced the observed inundation. It is likely that the farthest points of the observed inundation extent are associated with flooding by the '01:35' wave.

For the sake of brevity we discuss only the computed inundation according to the JDM. Recall that the modeled inundation induced by the tectonic sources is computed on a fixed tide level equal to the MHHW level. Thus, in the computer experiment, the old town area is flooded several times; each occurrence corresponds to an above-zero sea level, shown on the top plot in figure 27. Most of the town flooding is associated with five waves, which arrive at the town before 2:00 a.m. in the computer simulation. The waves arrive at distinct intervals and have almost the same duration and height, hence all these waves produce approximately the same inundation pattern. Therefore, the inundation extent at the end of the computer simulation is approximately equal to the inundation extent by any of these five waves. Considering that in the numerical experiment the inundation is computed at MHHW, the inundation by the ' $01: 35$ ' wave in the computer experiment represents the inundation by the ' $01: 35$ ' wave during the 1964 tsunami, and thus the modeled and observed inundation extents can be meaningfully compared.

We find a good comparison between the inundation extent in the case of SDM and the observed inundation (fig. 28). At some locations, the computed inundation limit lies further inland than the observed extent of inundation, however, that could be due to inaccuracies in the deformation model, unresolved structures such as buildings, errors in the DEM ${ }_{64}$ (some eyewitnesses report that up to $1.5 \mathrm{~m}[5 \mathrm{ft}]$ of snow blanketed the ground just prior to the earthquake and snow berms channeled the water flow), and a small bottom friction 
coefficient $\mu=0.01 \mathrm{~m}^{1 / 3} / \mathrm{s}\left(0.015 \mathrm{ft}^{1 / 3} / \mathrm{s}\right)$. The inundation due to the JDM seems to overestimate the observed inundation due to the same reasons, however, its fit could be better if the bottom friction were increased several times. Nevertheless, despite some discrepancies between the computed and observed inundation extents, from the point of view of tsunami hazard mitigation, the presented numerical modeling study shows that both the SDM and JDM provide a conservative approximation of the 1964 inundation if exactly the same earthquake were to occur again.

\section{Results of Hypothetical Tsunami Scenarios}

We performed numerical calculations for a total of 22 scenarios including both landslide- and tectonically-generated tsunamis. For scenarios related to the landslide-generated tsunamis, we simulated the water dynamics and computed the runup only in the high-resolution grid. For scenarios that describe tectonic tsunamis, we modeled the water dynamics in each grid (listed in table 2) and computed the extent of inundation only in the high-resolution grid.

We begin discussion of our modeling results by noting that a potential rupture of the Yakataga segment predicts subsidence of the ocean bottom in the eastern Prince William Sound (PWS) area, while the Johnson and Suito deformation models (JDM and SDM; scenarios 1 and 2, respectively) and field observations in 1964 show an uplift in this region. Because the water dynamics produced by the JDM and SDM simulations are similar, the following discussion for the sake of brevity focuses on only the JDM scenario. The vertical uplift of the multi-segment JDM rupture (scenario 3 ) in the eastern PWS region, in general, is less than that produced by the JDM rupture (scenario 1). Additionally, according to the multi-segment JDM rupture (scenario 3), Port Valdez subsides deeper than according to the JDM rupture (scenario 1). The effects of the lesser uplift in the PWS region and the larger subsidence in Port Valdez for the multi-segment JDM rupture results in a water surface gradient between PWS and Port Valdez that is approximately equal to the gradient caused by the JDM rupture. Therefore, the height of the leading wave from the multi-segment JDM rupture is about the same as that due to the JDM rupture.

In figure 29a, we show the computed sea level dynamics at point 34, in the eastern part of Port Valdez for the JDM (scenario 1), the multi-segment JDM rupture (scenario 3), and the YY segment rupture (scenario 5). The wave from the rupturing YY segment arrives approximately 2 hours after the onset of the earthquake and has the maximum wave height of

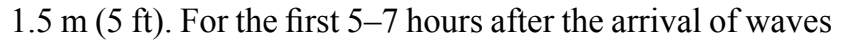
from the YY segment, the wave height in scenario 3 is approximately equal to the sum of wave heights for scenarios 1 and 5. However, the linear combination of the tsunami waves after 6 hours becomes less accurate due to cumulative effects of the non-linearities in the tsunami dynamics. The maximum height of the modeled tectonic tsunami in scenario 1 is 3.37 $\mathrm{m}(11.0 \mathrm{ft})$; even though the rupture in scenario 3 models a far greater earthquake in terms of rupture area, the maximum wave height for scenario 3 is only $3.47 \mathrm{~m}(11.4 \mathrm{ft})$. Thus, the modeled inundations in scenarios 1 and 3 are only slightly different in the city of Valdez. The computed inundation zones are distinctive due to different amounts of subsidence and the non-linear nature of the runup. Figure $29 \mathrm{~b}$ shows computed inundation zones for tsunamis generated by a potential rupture of the 1964 Great Alaska Earthquake (scenario 1) and its extension over the YY segment (scenario 3).

Analysis of tsunamis triggered by rupturing of the Kodiak Island (KI) asperity of the 1964 event, according to either scenario 8 or 10 , reveals that the waves arriving in the Valdez harbor do not exceed $0.6 \mathrm{~m}(2 \mathrm{ft})$ height and can produce only moderate inundation of low-lying areas. The comparison of numerical results related to rupturing of the entire 1964 zone (scenarios 1 and 2) and its PWS asperity alone (scenarios 7 and 9, respectively) shows that the modeled inundation zones are almost identical in Valdez, because the tsunami arrives at Port Valdez primarily from the PWS region. Similar results are obtained by comparing the wave caused by the multisegment rupture (scenarios 3 and 4 ) against the wave related to the rupture of the PWS and YY segments (scenarios 11 and 12 , respectively). Therefore, we only plot the following potential inundation zones in figure 30: Inundation zones related to scenario 1 (the JDM of the 1964 rupture; delineated by blue line), scenario 3 (the multi-segment JDM event; brown line), scenario 5 (the YY segment rupture; pink line), scenario 6 (the Cascadia zone rupture; cyan line), and scenarios 13-15 (describing a hypothetical $\mathrm{M}_{\mathrm{w}} 8.8$ earthquake in the Gulf of Alaska with various rupture zone parameterizations; green, red and violet lines). We note that the hypothetical $\mathrm{M}_{\mathrm{w}} 8.8$ earthquakes (scenarios 13-15) result in a larger amount of subsidence of Port Valdez than by any other tectonic scenarios based on either the SDM or the JDM of the 1964 rupture. Hence, scenarios 13-15 lead to the greater inundation zones among all considered tectonic scenarios.

Finally, we analyze potential inundation by the landslidegenerated tsunamis according to scenarios 16-22. For scenarios 16 and 17 there is an uncertainty in the location where most of the ground failure can occur. Therefore, we considered several sub-scenarios for each scenario, identifying each by the scenario number and the location of the slide's main body appended to it. In figure 31 , we plot the computed inundation extents at the head of Port Valdez related to the all sub-scenarios of scenario 16 , which is associated with failing of the hypothetical HPV slide. Note that the modeled inundation extents are confined to a relatively narrow band along the shoreline, with some variability in the inundation patterns among the considered sub-scenarios. For example, the sub-scenario 16-south results in a greater extent at the northeastern part of the shore among all considered sub-scenarios. Similarly, sub-scenarios 16-central and 16-north result in further inundation at the southeastern part of the shore. Thus to account for the variability among all sub-scenarios, and then to construct a single inundation extent related to scenario 16, we compute the maximum composite inundation among all its sub-scenarios: 16-uniform, 16-south, 16-center, 16-north, and 16-envelope. We then similarly compute the inundation extent for scenario 17 . Note that according to the 


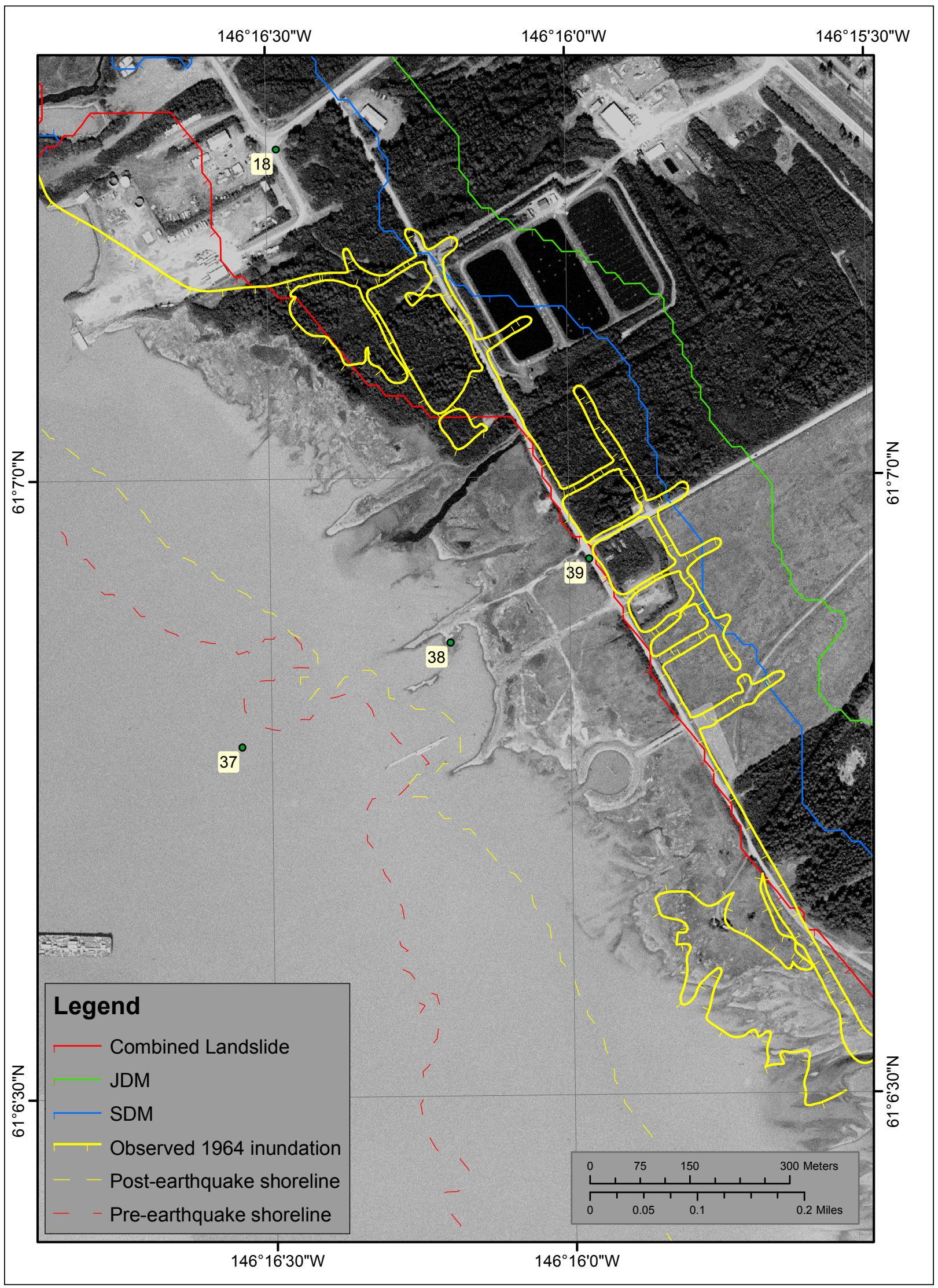

Figure 28. Observed and modeled 1964 inundation caused by tectonic- and landslide-generated waves. The yellow line represents observed inundation caused by the 1964 tsunami. The modeled MLLW shoreline before the earthquake is shown by a dashed yellow line. Hachures indicate the water side of the inundation lines. 


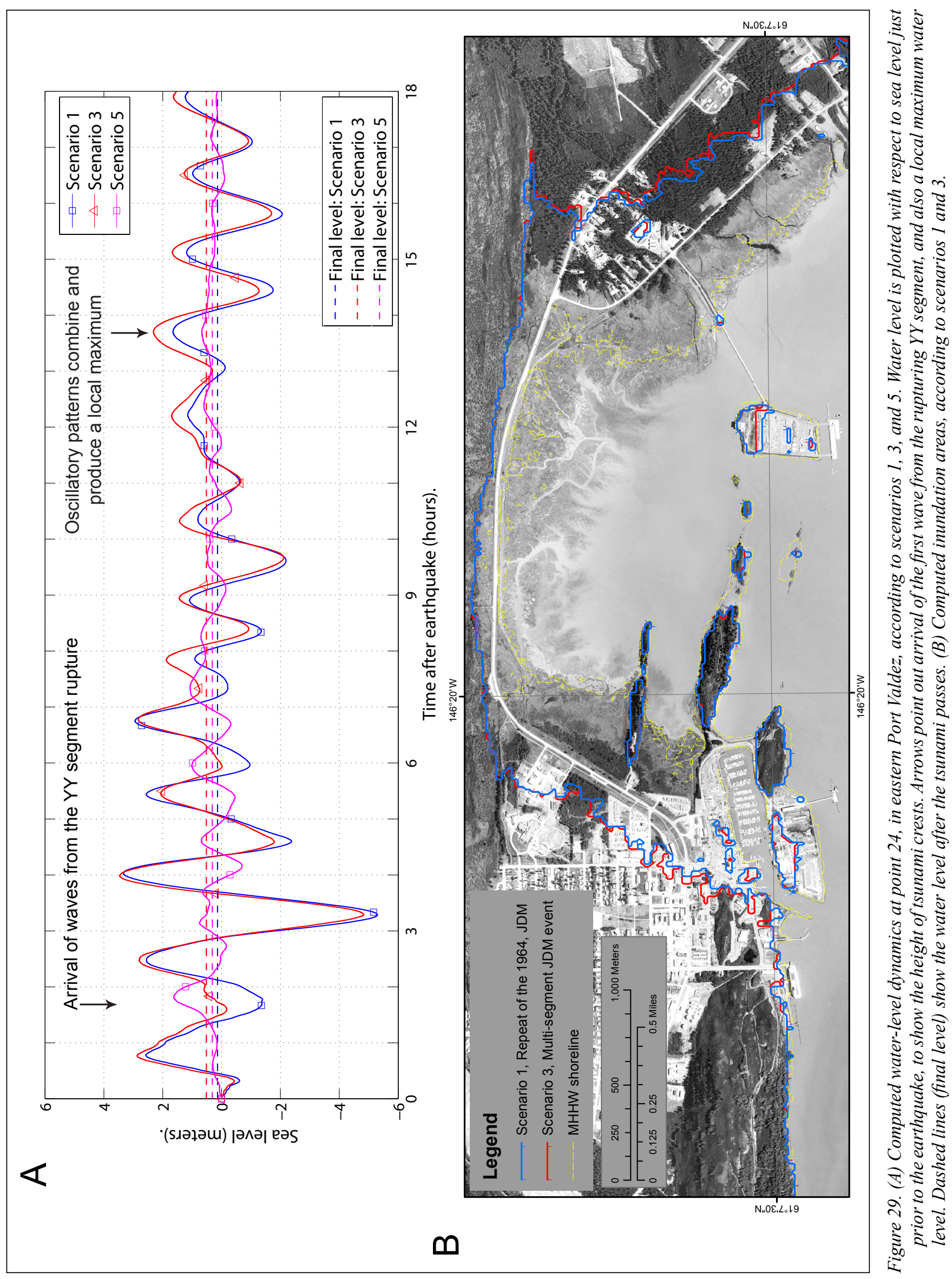



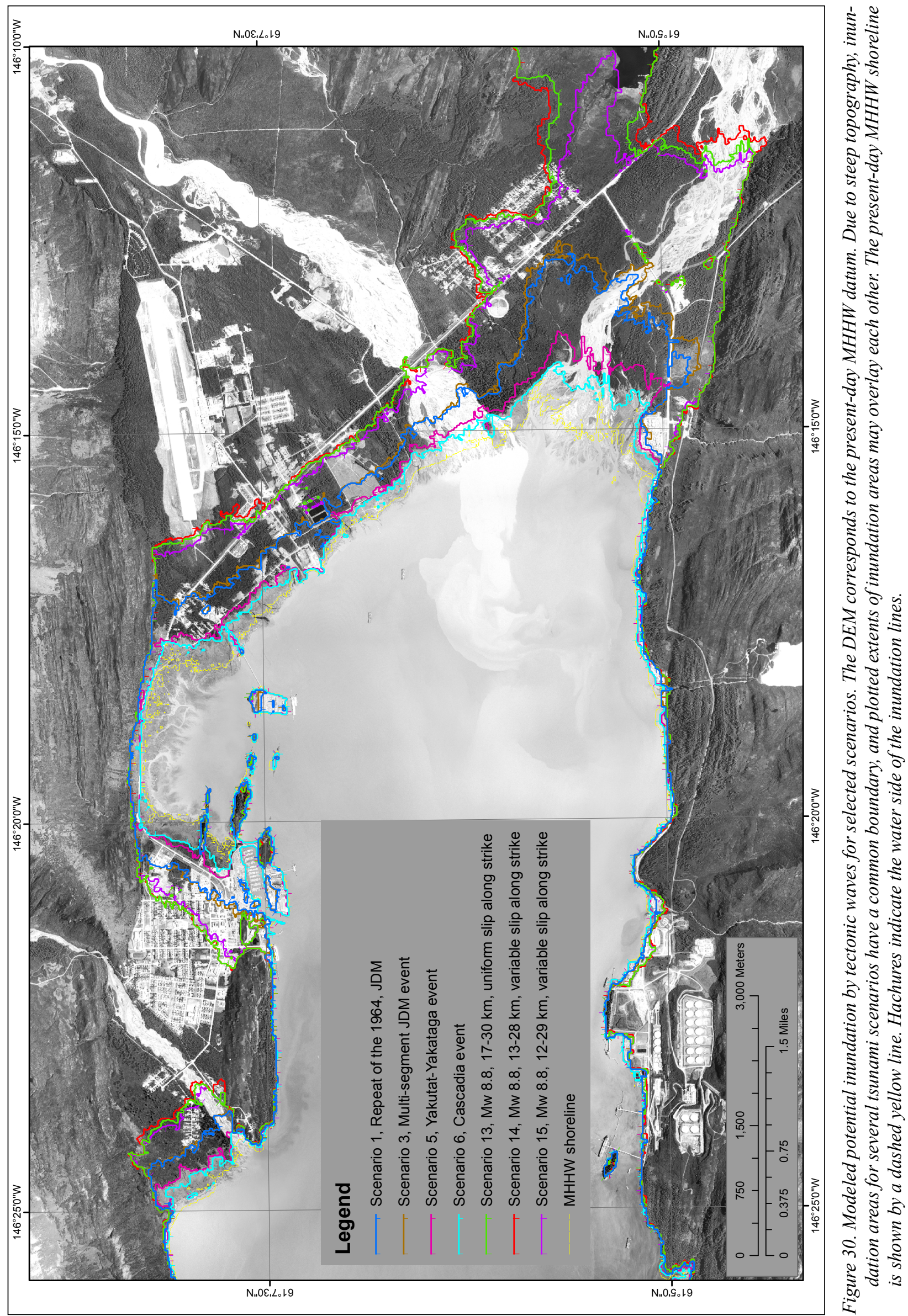


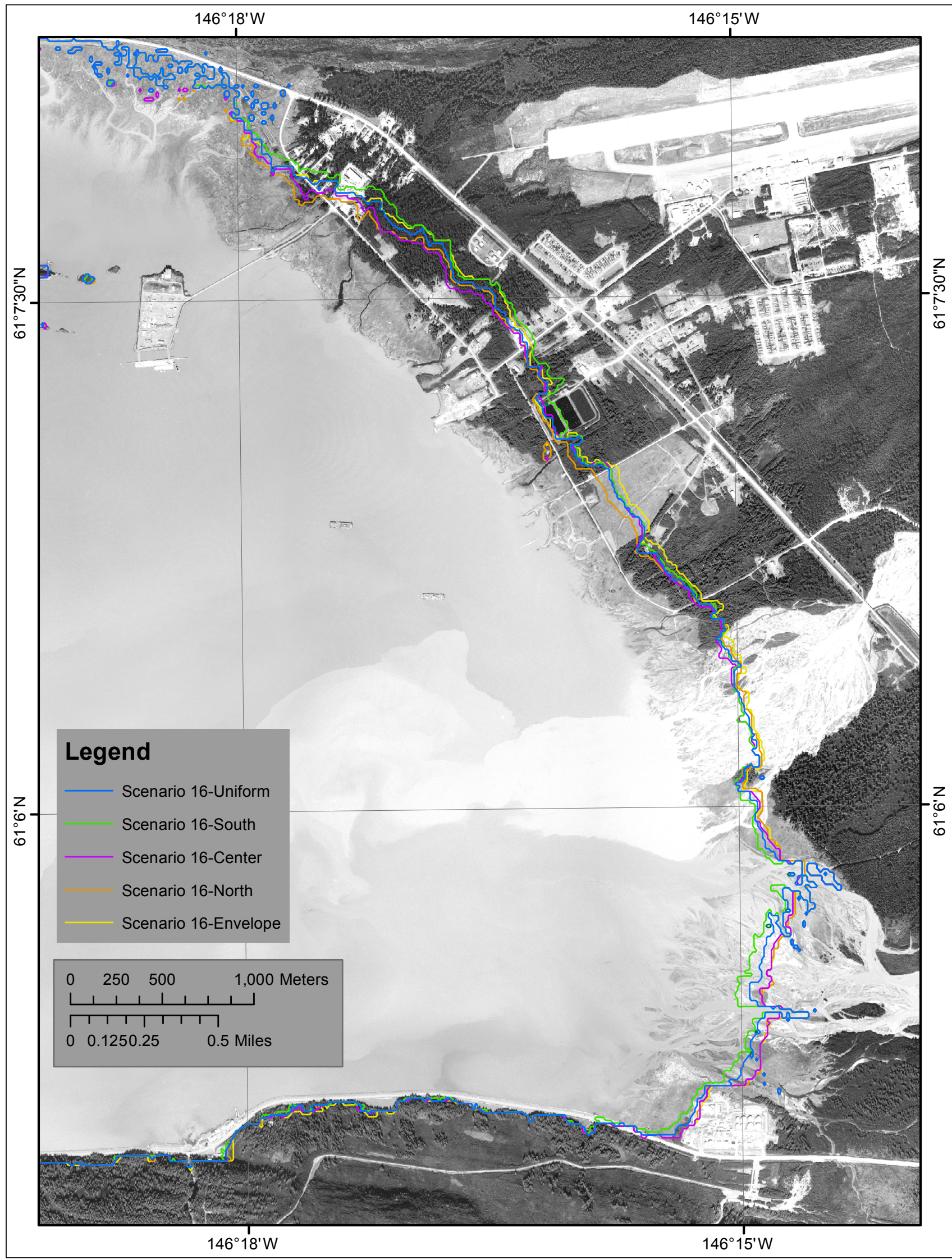

Figure 31. Modeled potential inundation by landslide-generated waves for all sub-scenarios of scenario 16. The DEM corresponds to the present-day MHHW datum. Due to steep topography, inundation areas for several tsunami scenarios have a common boundary, and plotted extents of inundation areas may overlay each other. 
above comparison of the modeled and observed runup in 1964, the potential runup of the landslide-generated tsunami near the Cliff Mine can be underestimated, while near Anderson Bay can be overestimated. Thus, we emphasize that the inundation lines for all scenarios are mere guidelines for the potential inundation in case of the real event.

We compute the inundation extents in Port Valdez for all landslide scenarios 16-22 (fig. 32). The tsunami generated by the HPV slide (scenario 16) clearly produces one of the largest inundations in the eastern part of the bay. The greatest inundation is associated with scenario 22, which describes the tsunami generated by the combined landslide. Almost everywhere the tsunami inundation according to scenario 22 exceeds other inundation extents except for a shoreline segment at the northeast corner of Port Valdez, probably due to negative wave interference. Positive wave interference is most pronounced at the right bank of Mineral Creek. In the computer experiment, the wave crests generated by the collapse of SBM and HPV slides arrive at the Mineral Creek delta at the same time, and thus cause an inundation that is much greater than each source considered separately. We emphasize that in the numerical experiments, all landslides are triggered simultaneously, and thus the wave crests meet offshore of Mineral Creek. If there is a temporal delay in the triggering of the slides, or a different physical mechanism of the slide dynamics, then the local maximum in the inundation can shift to the east or to the west of its calculated location.

Finally, we compute the maximum composite calculated extent of inundation for all scenarios, and the maximum composite flow depths over dry land (appx. B). Tsunami flow depth is an important indicator of potential damage, and must be differentiated from runup height (Synolakis and Bernard, 2006). For easier visual reference, we indicate the values of $0.5 \mathrm{~m}(1.6 \mathrm{ft})$, which approximately corresponds to knee height, and $2 \mathrm{~m}(6.6 \mathrm{ft})$, which is just above average body height.

\section{Time Series and other Numerical Results}

To help emergency managers assess the tsunami hazard in Valdez, we supplement the inundation maps with the time series of the modeled water level and velocity dynamics at certain locations around Port Valdez. The locations were chosen in cooperation with the City Manager of Valdez. For each location shown by a number in figure A-1 (a and b), we plot the sea level and water velocity in figures A-2 and A-3. The zero time corresponds to the epicenter origin time. Elevations of onshore locations correspond to the postearthquake MHHW datum. To show the height of arriving tsunamis for offshore locations, we use a vertical datum with a zero mark corresponding to the pre-earthquake sea level (pre-eq MHHW). The dashed lines show water levels after the tsunami. The velocity magnitude is calculated as water flux divided by water depth, thus the velocity value can have large uncertainties when the water depth is small. In the plots provided, the velocity is computed only where the water depth is greater than $0.3 \mathrm{~m}(1 \mathrm{ft})$.
Analysis of the time series plot shows that the hypothetical HPV slide (scenario 16) can create a devastating wave directed toward the city of Valdez and Alyeska Pipeline Marine Terminal as well; see points 4, 12, 22, and 27. The potential SBM slide (scenario 17) can also impact the harbor area as seen at points 2,8 , and 11, and produces some waves at berths of the Marine Terminal, as seen in points 24, and 26. Note that at points 7,8 , and 11 , the simulated wave is highest for the combined slide (scenario 22). Although a hypothetical failing of sediments offshore of the Lowe River (scenario 19) produces a relatively small wave, as seen at point 34 , it can produce modest flooding in the harbor area and container terminal. The numerical calculations show that the runup from the SBM slide at certain areas in Anderson Bay can reach up to $40 \mathrm{~m}(130 \mathrm{ft})$. Large uncertainties in the digital elevation model (DEM) along the shore of Anderson Bay impede development of inundation maps west of the Marine Terminal on the south shore and west of Mineral Creek on the north shore.

\section{SOURCES OF ERRORS AND UNCERTAINTIES}

The hydrodynamic model used to calculate propagation and runup of tsunami waves is a nonlinear, flux-formulated, shallow-water model (Nicolsky and others, 2011). It passes the validation and verification tests required for models used in production of tsunami inundation maps (Synolakis and others, 2007; NTHMP 2012). The viscous-elastic slide model used to simulate generation of the tsunami waves due to sliding of the ground material to the fjord bottom was successfully applied in other case studies in similar geologic settings, however the benchmarking procedures for this type of model is yet to be developed.

Numerical modeling of the 1964 blocky slide near Shoup Bay moraine was accomplished with the viscous-elastic model. The solid-block slide models have a tendency to overestimate the height of the generated wave, and their applicability for the tsunami hazard mitigation products needs to be further studied (James Kirby, University of Delaware, oral commun., 2013). Most likely the volume and geometry of the initial ground failure provide the largest uncertainties in the landslide-generated tsunami modeling studies. Finally, we note that the modeling results of the landslide-generated tsunami with the calibrated bottom drag coefficient $(\mu=0.01$ $\left.\mathrm{m}^{1 / 3} / \mathrm{s}\left[0.015 \mathrm{ft}^{1 / 3} / \mathrm{s}\right]\right)$ are in adequate agreement with the limited observations, and thus the results of the hypothetical scenarios can be used as a guideline to an extent of the potential inundation.

Because the initial condition for the modeling is determined by the displacement of the ocean bottom, the largest source of errors is the earthquake model. When the tsunami is generated in the vicinity of the coast, the direction of the incoming waves, their amplitudes, and times of arrival are determined by the initial displacements of the ocean surface in the source area because the distance to the shore is too small for the waves to disperse. Therefore, the near-field 

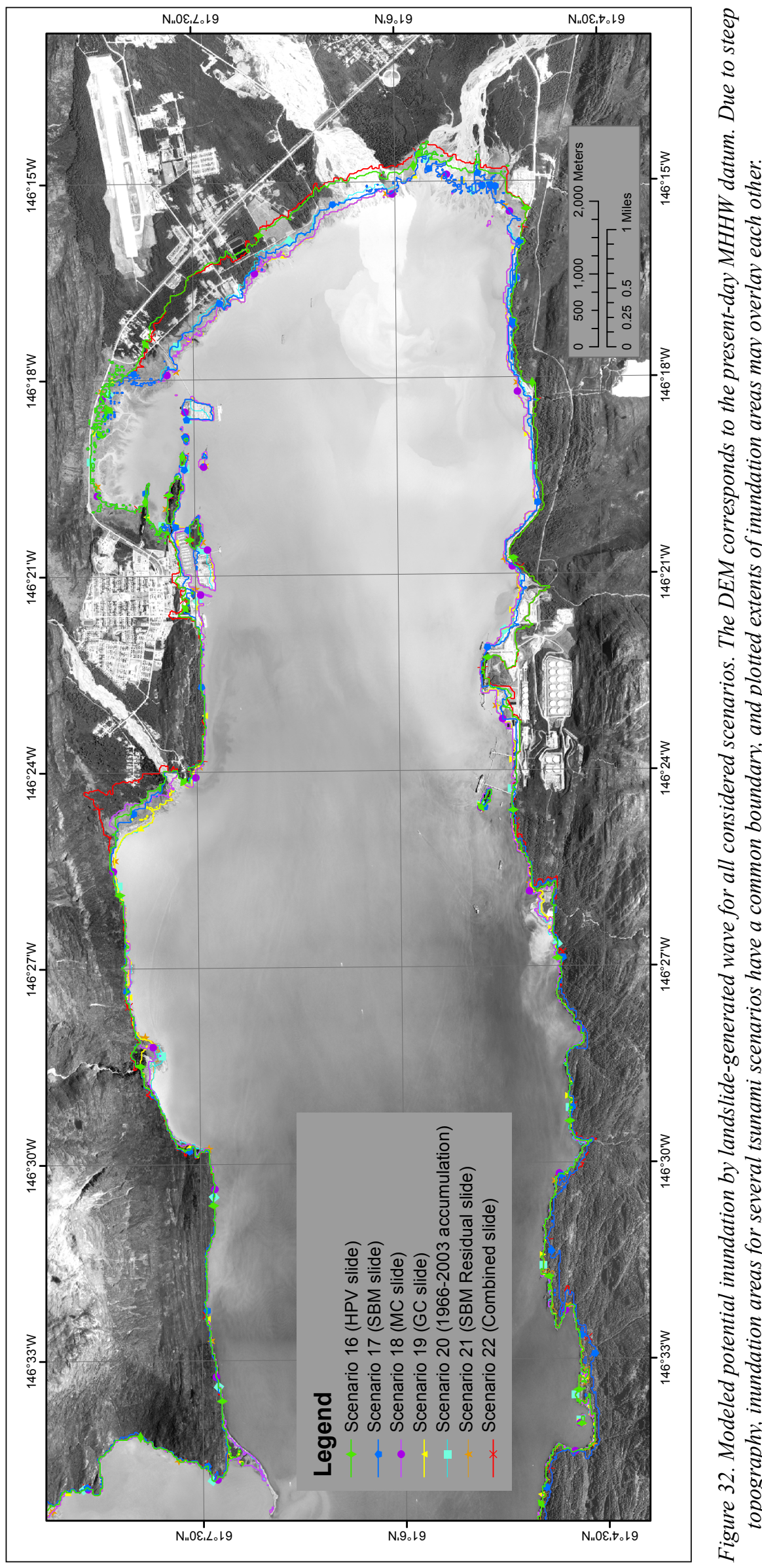
inundation modeling results are especially sensitive to the fine structure of the tsunami source. The modeling process is highly sensitive to errors when the complexity of the source function is combined with its proximity to the coastal zone.

During development of the tsunami inundation maps, a spatially averaged ground subsidence model was assumed for the entire city of Valdez. However, during a potential earthquake, soil compaction in areas of unconsolidated deposits in the coastal area might occur and the extent of the tsunami inundation could be farther landward. Finally, we mention that the horizontal resolution of the grid used for inundation

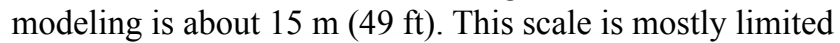
by the computational resources necessary to compute the tsunami inundation at the higher resolution. The $15 \mathrm{~m}$ (49 ft) resolution is high enough to describe major relief features, but small topographic features, buildings, and other facilities cannot be accurately resolved by the existing model.

\section{SUMMARY}

We present the results of numerical modeling of earthquake-generated tsunamis for the Valdez area and Port Valdez, Alaska. Both tectonic and submarine landslidegenerated tsunamis can have significant impacts, and our modeling shows that both were important for describing inundation following the 1964 earthquake. The maps showing the results of our modeling have been completed using the best information available, and are believed to be accurate; however, their preparation required many assumptions. We considered several tectonic and landslide scenarios and provide an estimate of maximum credible tsunami inundation. Actual conditions during a tsunami event may vary from those considered, so the accuracy cannot be guaranteed. The limits of inundation shown should be used only as a guideline for emergency planning and response action. Actual areas inundated will depend on specifics of the earth deformations, on-land construction, and tide level, and they may differ from areas shown on the map. The information on this map is intended to permit state and local agencies to plan emergency evacuation and tsunami response actions in the event of a major tsunamigenic earthquake. These results are not intended for land-use regulation or building-code development.

\section{ACKNOWLEDGMENTS}

This project was supported by the National Oceanic and Atmospheric Administration (NOAA) under Reimbursable Service Agreement ADN 0931000 with State of Alaska's Division of Homeland Security \& Emergency Management. Some of the research in this publication is sponsored by the University of Alaska Fairbanks Cooperative Institute for Alaska Research with funds from NOAA under cooperative agreement NA08OAR4320751 with the University of Alaska. Numerical calculations for this work were supported by a grant of High Performance Computing (HPC) resources from the Arctic Region Supercomputing Center (ARSC) at the University of Alaska Fairbanks. Reviews by Rob Witter and one anonymous reviewer improved the report and maps.
We would like to thank K. Labay and D. West for the development of the high-resolution DEM of Port Valdez; and N. Ruppert, D. Christensen, and J. Freymueller for their help in developing the hypothetical scenarios.

\section{REFERENCES CITED}

Assier-Rzadkiewicz, S., Mariotti, C., and Heinrich, P., 1997, Numerical simulation of submarine landslides and their hydraulic effects: Journal of Waterway, Port, Coastal, and Ocean Engineering, v. 123, no. 4, p. 149-157, doi: 10.1061/(ASCE)0733-950X(1997)123:4(149).

Atwater, B.F., 1987, Evidence for great Holocene earthquakes along the outer coast of Washington state: Science, v. 236, p. 942-944.

Atwater, B.F., Musumi-Rokkaku, Satoku, Satake, Kenji, Tsuji, Yoshinobu, Ueda, Kazue, and Yamaguchi, D.K., 2005, The orphan tsunami of 1700 - Japanese clues to a parent earthquake in North America: U.S. Geological Survey Professional Paper 1707 (prepared in cooperation with the Geological Survey of Japan, the University of Tokyo, and the University of Washington, and published in association with University of Washington Press), $133 \mathrm{p}$.

Begét, J., 2007, Earthquake, landslide, and tsunami hazards in the Port Valdez area, Alaska - Consultation to the Prince William Sound Regional Citizen's Advisory Council (PWSRCAC), Alaska Begét Consulting, PWSRCAC commissioned report.

Bornhold, B.D., Thomson, R.E., Rabinovich, A.B., Kulikov, E.A., and Fine, I.V., 2001, Risk of landslide-generated tsunamis for the coast of British Columbia and Alaska, in Mahmoud, M., van Everdingen, R., and Carss, J., eds., An earth odyssey-Proceedings of the 54th Canadian Geotechnical Society Conference: Richmond, B.C., Bitech Publishers, Ltd., p. 1,450-1,454.

Brocher, T.M., Fuis, G.S., Fisher, M.A., Plafker, George, Taber, J.J., and Christensen, N.I., 1994, Mapping the megathrust beneath the northern Gulf of Alaska using wide-angle seismic data: Journal of Geophysical Research, v. 99, p. 11,663-11,685.

Caldwell, R.J., Eakins, B.W., and Lim, E., 2009, Digital elevation models of Prince William Sound, Alaska-Procedures, data sources and analysis: Boulder, Colorado, National Geophysical Data Center, NOAA, 43 p., www. ngdc.noaa.gov/dem/report/download/1305.

Carver, G.A., and Plafker, George, 2008, Paleoseismicity and neotectonics of the Aleutian subduction zone-An overview, in Freymueller, J.T., Haeussler, P.J., Wesson, R.L, and Ekström, G., eds., Active tectonics and seismic potential of Alaska: American Geophysical Union Geophysical Monograph 179, p. 43-63.

Chance, J., 1972, Perceptions of earthquake-related physical events in coastal communities, appendix - Summary and recommendations, in The Great Alaska Earthquake of 1964: Washington, D.C., National Academy of Sciences-Engineering, p. 117-136.

Christensen, D.H., and Beck, S.L., 1994, The rupture process and tectonic implications of the Great 1964 Prince Wil- 
liam Sound Earthquake: Pure and Applied Geophysics, v. 142 , no. 1 , p. $29-53$.

Coulter, H.W., and Migliaccio, R.R., 1966, Effects of the earthquake of March 27, 1964 at Valdez, Alaska: U.S. Geological Survey Professional Paper, 542-C, 36 p.

DeMets, Charles, Gordon, R.C., Argus, D.F., and Stein, Seth, 1990, Current plate motions: Geophysical Journal International, v. 101, no. 2, p. 425-478.

Doser, D.I., 2006, Relocation of earthquakes (1899-1917) in south-central Alaska: Pure and Applied Geophysics, v. 163 , p. 1,461-1,476.

Doser, D.I., 2009, Estimating magnitude and location of Alaskan earthquakes using intensity data: Bulletin of the Seismological Society of America, v. 99, no. 6, p. 3,430-3,453.

Doser, D.I., and Brown, W.A., 2001, A study of historic earthquakes of the Prince William Sound, Alaska, region: Bulletin of the Seismological Society of America, v. 91, no. 4 , p. $842-857$.

Doser, D.I., Veilleux, A.M., and Velasquez, M., 1999, Seismicity of the Prince William Sound region for thirty-two years following the 1964 great Alaskan earthquake: Pure and Applied Geophysics, v. 154, p. 593-632.

Doser, D.I., de la Peña, A., and Veilleux, A.M., 2005, Seismicity of the Prince William Sound region and its relation to plate structure and the 1964 great Alaska earthquake, in Freymueller, J.T., Haeussler, P.J., Wesson, R., and Ekstrom, G., eds., Active Tectonics and Seismic Potential of Alaska: American Geophysical Union Monograph 179, p. 201-214.

Fine, I.V., Rabinovich, A.B., Kulikov, E.A., Thomson, R.E., and Bornhold, B.D., 1998, Numerical modeling of landslide-generated tsunamis with application to the Skagway Harbor tsunami of November 3, 1994, in Proceedings, International Conference on Tsunamis: Paris, France, May 26-28, 1998, Commissariat à l'Energie Atomique (CEA), p. 211-223.

Freund, L.B., and Barnett, D.M., 1976, A two-dimensional analysis of surface deformation due to dip-slip faulting: Bulletin of the Seismological Society of America, v. 66, p. 667-675.

Freymueller, J.T., Woodard, H., Cohen, S., Cross, R., Elliott, J., Larsen, C., Hreinsdottir, S., and Zweck, C., 2008, Active deformation processes in Alaska, based on 15 years of GPS measurements, in Freymueller, J.T., Haeussler, P.J., Wesson, R., and Ekstrom, G., eds., Active Tectonics and Seismic Potential of Alaska: Washington, D.C., American Geophysical Union Geophysical Monograph, 179 , p. 1-42.

Geist, E.L., and Dmowska, R., 1999, Local tsunamis and distributed slip at the source: Pure and Applied Geophysics, v. 154, p. 485-512.

Goto, C., Ogawa, Y., Shuto, N., and Imamura, F., 1997. Numerical method of tsunami simulation with the leap-frog scheme: UNESCO, IUGG/IOC TIME Project, Manuals and Guides 35.
Grant, U.S., and Higgins, D.F., Jr., 1913, Coastal glaciers of Prince William Sound and Kenai Peninsula, Alaska: U.S. Geological Survey Bulletin 526, 75 p., 2 sheets, scale 1:500,000.

Hamilton, Sarah, and Shennan, Ian, 2005, Late Holocene great earthquakes and relative sea-level change at Kenai, southern Alaska: Journal of Quaternary Science, v. 20, no. 2, p. 95-111.

Hampton, M.A., Lee, H.J., and Locat, Jacques, 1996, Submarine landslides: Reviews of Geophysics, v. 34, no. 1, p. 33-59.

Hayes, G.P., Wald, D.J., and Johnson, R.L., 2012, Slab1.0: A three-dimensional model of global subduction zone geometries: Journal of Geophysical Research, v. 117, no. B01, p. 302, doi:10.1029/2011JB008524.

Holdahl, S.R., and Sauber, Jeanne, 1994, Coseismic slip in the 1964 Prince William Sound earthquake-A new geodetic inversion: Pure and Applied Geophysics, v. 142, no. 1 , p. 55-82.

Ichinose, Gene, Somerville, Paul, Thio, H.K., Graves, Robert, and O'Connell, Dan, 2007, Rupture process of the 1964 Prince William Sound, Alaska, earthquake from the combined inversion of seismic, tsunami, and geodetic data: Journal of Geophysical Research, v. 112, no. B07, p. 306, 21 p., doi:10.1029/2006JB004728.

Jiang, Lin, and LeBlond, P.H., 1992, The coupling of a submarine slide and the surface waves which it generates: Journal of Geophysical Research, v. 97, no. C8, p. 12,731-12,744.

Jiang, Lin, and LeBlond, P.H., 1994, Three-dimensional modeling of tsunami generation due to a submarine mudslide: Journal of Physical Oceanography, v. 24, no. 3, p. 559-572.

Johnson, J.M., Satake, Kenji, Holdahl, S.R., and Sauber, Jeanne, 1996, The 1964 Prince William Sound earthquake-Joint inversion of tsunami waveforms and geodetic data: Journal of Geophysical Research, v. 101, no. B1, p. 523-532.

Kachadoorian Reuben, 1965, Effects of the earthquake of March 27, 1964, at Whittier, Alaska: U.S. Geological Survey Professional Paper 542-B, p. B1-B21, 3 sheets, scale $1: 4,800$.

Kowalik, Zygmunt, and Proshutinsky, Andrey, 2010, Tsunami-tide interactions-A Cook Inlet case study: Continental Shelf Research, v. 30, p. 633-642.

Kowalik, Zygmunt, Proshutinsky, Tatiana, and Proshutinsky, Andrey, 2006, Tide-Tsunami Interactions: Science of Tsunami Hazards, v. 24, no. 4, p. 242-256.

Kulikov, E.A., Rabinovich, A.B., Fine, I.V., Bornhold, B.D., and Thomson, R.E., 1998, Tsunami generation by landslides at the Pacific coast of North America and the role of tides: Oceanology, v. 38, no. 3, p. 323-328.

Lander, J.F., 1996, Tsunamis affecting Alaska, 1737-1996: Boulder, Colorado, National Geophysical Data Center (NGDC), NOAA, Key to Geophysical Research Documentation, v. 31, 195 p. 
Lee, H.J., Ryan, H., Haeussler, P.J., Kayen, R.E., Hampton, M.A., Locat, J., Suleimani, E.N, and Alexander, C.R., 2007, Reassessment of seismically induced, tsunamigenic submarine slope failures in Port Valdez, Alaska, USA, in Lykousis, V., Sakellariou, D., and Locat, J., eds., Submarine Mass Movements and Their Consequences: Springer Netherlands, Advances in Natural and Technological Hazards Research, v. 27, p. 357-365.

Lemke, R.W., 1967, Effects of the earthquake of March 27, 1964, at Seward, Alaska: U.S. Geological Survey Professional Paper 542-E, 43 p., 2 sheets, scale 1:63,360.

Lim, E., Eakins, B.W., and Wigley, R., 2009, Southern Alaska coastal relief model-Procedures, Data Sources, and Analysis: National Geophysical Data Center, NOAA, 25 p., http://www.ngdc.noaa.gov/mgg/coastal/s_alaska.html

Linsley, R., and Franzini, J., 1979, Water Resources Engineering: New York, McGraw-Hill, 716 p.

Moore, J.C., Diebold, John, Fisher, M.A., Sample, J., Brocher, T., Talwani, M., Ewing, John, von Huene, R., Rowe, C., Stone, D., Stevens, Chris, and Sawyer, Dale, 1991, EDGE deep seismic reflection transect of the eastern Aleutian arc-trench layered lower crust reveals underplating and continental growth: Geology, v. 19, p. 420-424.

Moss, Robb E.S., and Travasarou, Thaleia, 2006, Tsunamigenic probabilistic fault displacement hazard analysis for subduction zones-Proceedings of the 8th U.S. National Conference on Earthquake Engineering: Earthquake Engineering Research Institute, Paper 238, 9 p.

National Geophysical Data Center/World Data Center (NGDC/WDC) Global Historical Tsunami Database, Boulder, CO, USA (available at http://www.ngdc.noaa. gov/hazard/tsu_db.shtml)

National Tsunami Hazard Mapping Program (NTHMP), 2010, Guidelines and best practices for tsunami inundation modeling for evacuation planning: NTHMP Mapping \& Modeling Subcommittee, NOAA.

2012, Proceedings and Results of the 2011 NTHMP Model Benchmarking Workshop: Boulder, CO, U.S. Department of Commerce/NOAA/NTHMP, NOAA Special Report, 436 p. (available at http://nthmp.tsunami.gov)

Nicolsky, D.J., 2012, Alaska tsunami model, in Proceedings and Results of The 2011 NTHMP Model Benchmarking Workshop: Boulder, CO, U.S. Department of Commerce/ NOAA/NTHMP, NOAA Special Report, p. 55-87 (available at http://nthmp.tsunami.gov).

Nicolsky, D.J., Suleimani, E.N., and Hansen, R.A., 2011a, Validation and verification of a numerical model for tsunami propagation and runup: Pure and Applied Geophysics, v. 168, p. 1,199-1,222, http://dx.doi.org/10.1007/ s00024-010-0231-9.

Nicolsky, D.J., Suleimani, E.N., Combellick, R.A., and Hansen, R.A., 2011b, Tsunami inundation maps of Whittier and western Passage Canal, Alaska: Alaska Division of Geological \& Geophysical Surveys Report of Investigation 2011-7, $65 \mathrm{p}$.

Nishenko, S.P., 1991, Circum-Pacific seismic potential, 19891999: Pure and Applied Geophysics, v. 135, p. 169-259.
Nishenko, S.P., and Jacob, K.H., 1990, Seismic potential of the Queen Charlotte-Alaska-Aleutian seismic zone: Journal of Geophysical Research, v. 95, no. B3, p. 2,511-2,532.

Ohta, Y., Freymueller, J.T., Hreinsdottir, S., and Suito, H., 2006, A large slow slip event and the depth of the seismogenic zone in the south-central Alaska subduction zone: Earth \& Planetary Science Letters, v. 247, p. 108-116, doi:10.1016/j.epsl.2006.05.013.

Okada, Yoshimitsu, 1985, Surface deformation due to shear and tensile faults in a half-space: Bulletin of the Seismological Society of America, v. 75, no. 4, p. 1,135-1,154.

Page, R.A., Biswas, N.N., Lahr, J.C., and Pulpan, Hans, 1991, Seismicity of continental Alaska, in Slemmons, D.B., Engdahl, E.R., Zoback, M.D., and Blackwell, D.D., eds., Neotectonics of North America: Boulder, Colorado, Geological Society of America, Decade Map Volume 1, p. 47-68.

Papazachos, B.C., Scordilis, E.M., Panagiotopoulos, D.G., Papazachos, C.B., and Karakaisis, G.F., 2005, Global relations between seismic fault parameters and moment magnitude of earthquakes: Bulletin of the Geological Society of Greece, v. 36, p. 1,482-1,489.

Plafker, George, 1967, Surface faults on Montague Island associated with the 1964 Alaska earthquake: U.S. Geological Survey Professional Paper 543-G, p. G1-G42.

1969, Tectonics: U.S. Geological Survey Professional Paper 543-I, p. G1-G74.

Plafker, George, and Mayo, L.R., 1965, Tectonic deformation, subaqueous slides and destructive waves associated with the Alaskan March 27, 1964 earthquake-An interim geologic evaluation: U.S. Geological Survey Open-File Report 65-124, 19 p.

Plafker, George, and Thatcher, Wayne, 2008, Geological and geophysical evaluation of the mechanisms of the Great 1899 Yakutat Bay Earthquakes, in Freymueller, J.T., Haeussler, P.J., Wesson, R.L., and Ekström, Goran, eds., Active tectonics and seismic potential of Alaska: Geophysical Monograph Series, v. 179, p. 215-236, ISBN 978-0-87590-444-3, doi 10.1029/179GM12, AGU code GM1794443.

Plafker, George, Kachadoorian, Reuben, Eckel, E.B., and Mayo, L.R., 1969, Effects of the earthquake of March 27, 1964 on various communities: U.S. Geological Survey Professional Paper 542-G, $50 \mathrm{p}$.

Priest, G.R., Goldfinger, Chris, Wang, Kelin, Witter, R.C., Zhang, Yinglong, and Baptista, A.M., 2009, Confidence levels for tsunami-inundation limits in northern Oregon inferred from a 10,000-year history of great earthquakes at the Cascadia subduction zone: Natural Hazards, v. 54, no. 1, DOI 10.1007/s11069-009-9453-5.

Rabinovich, A.B., Thomson, R.E., Bornhold, B.D., Fine, I.V., and Kulikov, E.A., 2003, Numerical modeling of tsunamis generated by hypothetical landslides in the Strait of Georgia, British Columbia: Pure and Applied Geophysics, v. 160, no. 7, p. 1,273-1,313. 
Ryan, H.F., Lee, H.J., Haeussler, P.J., Alexander, C.R., and Kayen, R.E., 2010, Historic and paleo-submarine landslide deposits imaged beneath Port Valdez, AlaskaImplications for tsunami generation in a glacial fiord, in Mosher, D.C. and others, eds., Submarine Mass Movements and Their Consequences: Advances in Natural and Technological Hazards Research, v. 28, Springer Science + Business Media B.V.

Santini, S., Dragoni, M., and Spada, G., 2003, Asperity distribution of the 1964 Great Alaska Earthquake and its relation to subsequent seismicity in the region: Tectonophysics, v. 367, no. 3-4, p. 219-233.

Satake, Kenji, Shimazaki, Kunihiko, Tsuji, Yoshinobu, and Ueda, Kazue, 1996, Time and size of a giant earthquake in Cascadia inferred from Japanese tsunami records of January 1700: Nature, v. 379, no. 6562, p. 246-249.

Satake, Kenji, Wang, Kelin, and Atwater, B.F., 2003, Fault slip and seismic moment of the 1700 Cascadia earthquake inferred from Japanese tsunami descriptions: Journal of Geophysical Research, v. 108, no. B11, p. 2,535-2,551, doi:10.1029/2003JB002521.

Savoie, M.A., Savoie, J.M., Trefry, J.H., Semmler, C.M., Woodall, D.W., Trocine, R.P., Brooks, J.M., and McDonald, Tom, 2006, Port Valdez sediment coring programFinal 2004 monitoring report: Kinnetic Laboratories, Inc. in association with Florida Institute of Technology \& TDI Brooks International, Inc., Contract No. 961.04.1 for Prince William Sound Regional Citizens' Advisory Council, Valdez, Alaska, 76 p., http://www.pwsrcac.org/ docs/d0024500.pdf.

Shannon, W., and Hilts, D., 1973, Submarine landslide at Seward, in The Great Alaska Earthquake of 1964: Washington, DC, Engineering( National Academy of Sciences), p. 144-156.

Shennan, Ian, Barlow, Natasha, and Combellick, R.A., 2008, Paleoseismological records of multiple great earthquakes in south-central Alaska-A 4,000-year record at Girdwood, in, Freymueller, J.T., Haeussler, P.J., Wesson, R.L, and Ekström, G., eds., Active Tectonics and Seismic Potential of Alaska: American Geophysical Union Geophysical Monograph 179, p. 185-199.

Shennan, I., Barlow, N., Pierre, K., Stuart-Taylor, O., and Sea Level Research Unit, Department of Geography, Durham University, 2012, Diatom stratigraphy of Borehole TA8, Portage, Alaska: Alaska Division of Geological \& Geophysical Surveys Geologic Materials Center Data Report 404, 26 p.

Shennan, Ian, Bruhn, Ronald, and Plafker, George, 2009, Multi-segment earthquakes and tsunami potential of the Aleutian megathrust: Quaternary Science Reviews, v. 28, no. 1-2, p. 7-13.

Sobolev, S.V., Babeyko, A.Y., Wang, R., Hoechner, A., Galas, R., Rothacher, M., Sein, D.V., Schröter, J., Lauterjung, J., and Subarya, C., 2007, Tsunami early warning using GPS-Shield arrays: Journal of Geophysical Research, v. 112 , no. B08, p. 415, doi:10.1029/2006JB004640.
Suito, Hisashi, and Freymueller, J.T., 2009, A viscoelastic and afterslip postseismic deformation model for the 1964 Alaska earthquake: Journal of Geophysical Research, v. 114, no. B11, p. 404-426, doi:10.1029/2008JB005954.

Suleimani, E.N., Combellick, R.A., Marriott, Duncan, Hansen, R.A., Venturato, A.J., and Newman, J.C., 2005, Tsunami hazard maps of the Homer and Seldovia areas, Alaska: Alaska Division of Geological \& Geophysical Surveys Report of Investigation 2005-2, 28 p., 2 sheets, scale 1:12,500.

Suleimani, E.N., Hansen, R.A., Combellick, R.A., Carver, G.A., Kamphaus, R.A., Newman, J.C., and Venturato, A.J, 2002, Tsunami hazard maps of the Kodiak area, Alaska: Alaska Division of Geological \& Geophysical Surveys Report of Investigation 2002-1, 16 p., 4 sheets, scale $1: 12,500$

Suleimani, E.N., Nicolsky, D.J., West, D.A., Combellick, R.A., and Hansen, R.A., 2010, Tsunami inundation maps of Seward and northern Resurrection Bay, Alaska: Alaska Division of Geological \& Geophysical Surveys Report of Investigation 2010-1, 47 p., 3 sheets, scale 1:63,360.

Synolakis, C.E., and Bernard, E.N., 2006, Tsunami science before and beyond Boxing Day 2004, in Thompson, J.M.T., Heppert, H.E., and Sparks, R.S.J., eds., Extreme Natural Hazards: Philosophical Transactions of the Royal Society, Mathematical, Physical, and Engineering Sciences, v. 364, no. 1845 , p. 2,231-2,265.

Synolakis, C.E., Bernard, E.N., Titov, V.V., Kânoğlu, U., and González, F.I., 2007, Standards, criteria, and procedures for NOAA evaluation of tsunami numerical models: Seattle, Washington, NOAA/Pacific Marine Environmental Laboratory, Technical Memorandum OAR PMEL-135, $55 \mathrm{p}$.

Tanaka, J.M. 1973, Relocation of Valdez, in The Great Alaska Earthquake of 1964: Washington, D.C., National Academy of Sciences-Engineering, p. 1,108-1,135.

Tarr, R.S., and Martin, Lawrence, 1912, The earthquakes at Yakutat Bay, Alaska, in September 1899; preface by G.K. Gilbert: U.S. Geological Survey Professional Paper 69, 135 p., 3 sheets, scale 1:5,000,000. http://pubs.er.usgs. gov/publication/pp69.

Thomson, R.E., Rabinovich, A.B., Kulikov, E.A., Fine, I.V., and Bornhold, B.D., 2001, On numerical simulation of the landslide-generated tsunami of November 3, 1994, in Skagway Harbor, Alaska, in Hebenstreit, G.T., ed., Tsunami research at the end of a critical decade: Kluwer, p. 243-282.

Titov, V.V., and Synolakis, C.E., 1995, Evolution and runup of breaking and nonbreaking waves using VTSC-2: Journal of Waterway, Port, Coastal and Ocean Engineering, v. 121 , no. 6 , p. $308-316$.

1997, Extreme inundation flows during the Hokkaido-Nansei-Oki Tsunami. Geophysical Research Letters, v. 24, no. 11, p, 1,315-1,318.

Wang, Kelin, Wells, R.E., Mazzotti, Stephane, Hyndman, R.D., and Sagiya, Takeshi, 2003, A revised dislocation 
model of interseismic deformation of the Cascadia subduction zone: Journal of Geophysical Research, v. 108, no. B1, p. 2,026-2,038, doi:10.1029/2001JB001227, http://www.agu.org/pubs/crossref/2003/2001JB001227. shtml.

Wilson, B.W., and Tørum, Alf, 1968, The tsunami of the Alaskan Earthquake, 1964-Engineering evaluation: Fort Belvoir, Virginia, U.S. Army Corps of Engineers Coastal Engineering Research Center, Technical Memorandum No. 25,410 p.

Wilson, B.W., and Tørum, Alf, 1972, Effects of the tsunamis-An engineering study, in The Great Alaska Earthquake of 1964: Washington, D.C., National Academy of Sciences-Engineering, p. 361-526.

Witter, R.C., Zhang, Y., Wang, K., Priest, G.R., Goldfinger, C., Stimely, L.L., English, J.T. and Ferro, P.A., 2011, Simulating tsunami inundation at Bandon, Coos County, Oregon, using hypothetical Cascadia and Alaska earthquake scenarios: Oregon Department of Geology and Mineral Industries Special Paper 43, 57 p.
Wolf, L.W., Stone, D.B., and Davies, J.N., 1991, Crustal structure of the active margin, south-central AlaskaAn interpretation of seismic refraction data from the Trans-Alaska Crustal Transect: Journal of Geophysical Research, v. 96, p. 16,455-16,469.

Zhao, D., Christensen, D., and Pulpan, Hans, 1995, Tomographic imaging of the Alaska subduction zone: Journal of Geophysical Research, v. 100, p. 6,487-6,504.

Zweck, C., Freymueller, J.T., and Cohen, S.C., 2002, Threedimensional elastic dislocation modeling of the postseismic response to the 1964 Alaska earthquake: Journal of Geophysical Research, v. 107, no B4, p. ECV1-1-ECV111, doi: 10.1029/2001JB000409. 


\section{APPENDIX A}

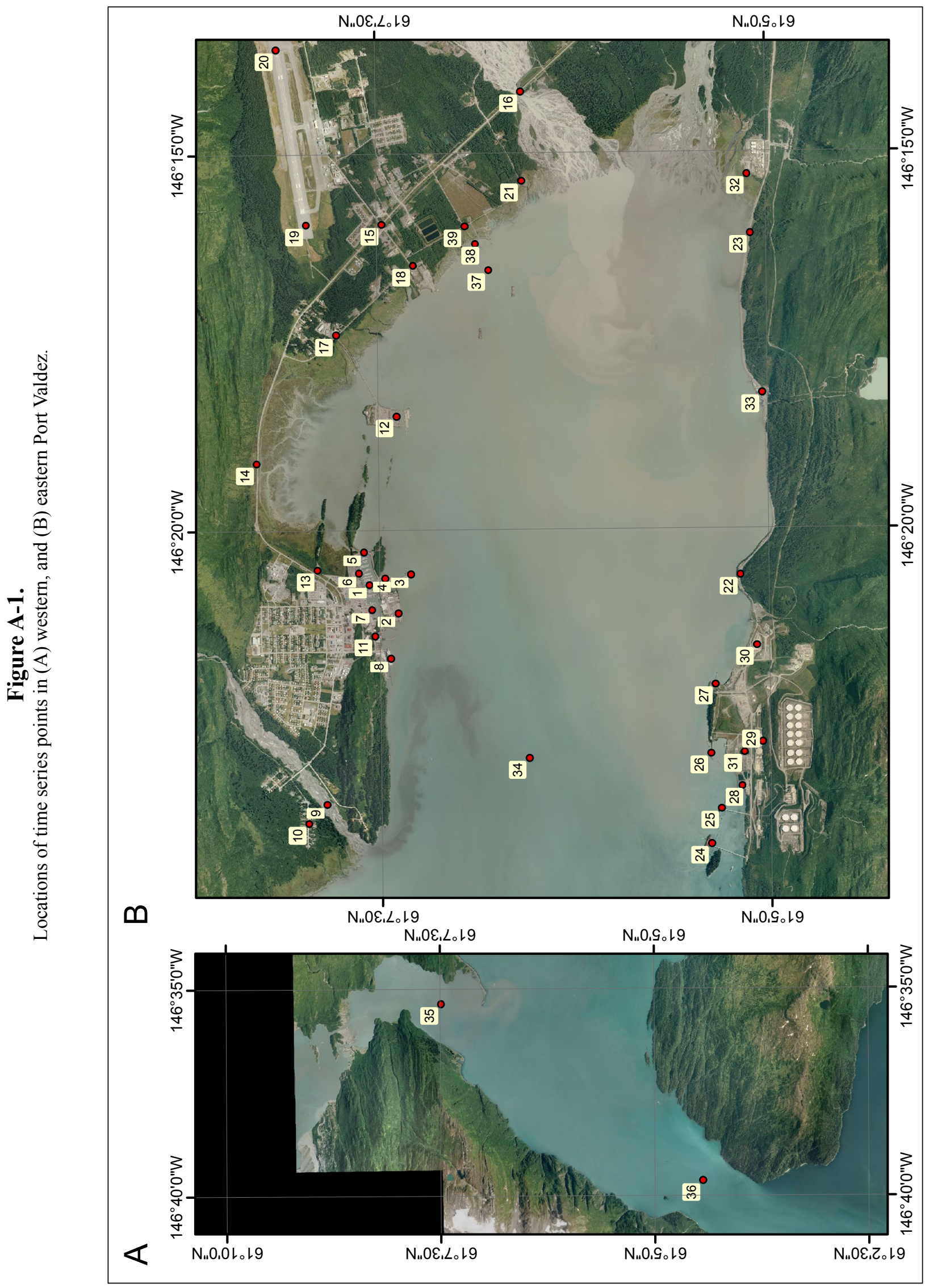




\section{Figure A-2}

Time series of water level and velocity at selected locations for scenarios 16-22. Elevations of onshore locations correspond to post-earthquake MHHW datum. For offshore locations, to show a height of arriving tsunami, the vertical datum is such that zero corresponds to the pre-earthquake sea level.
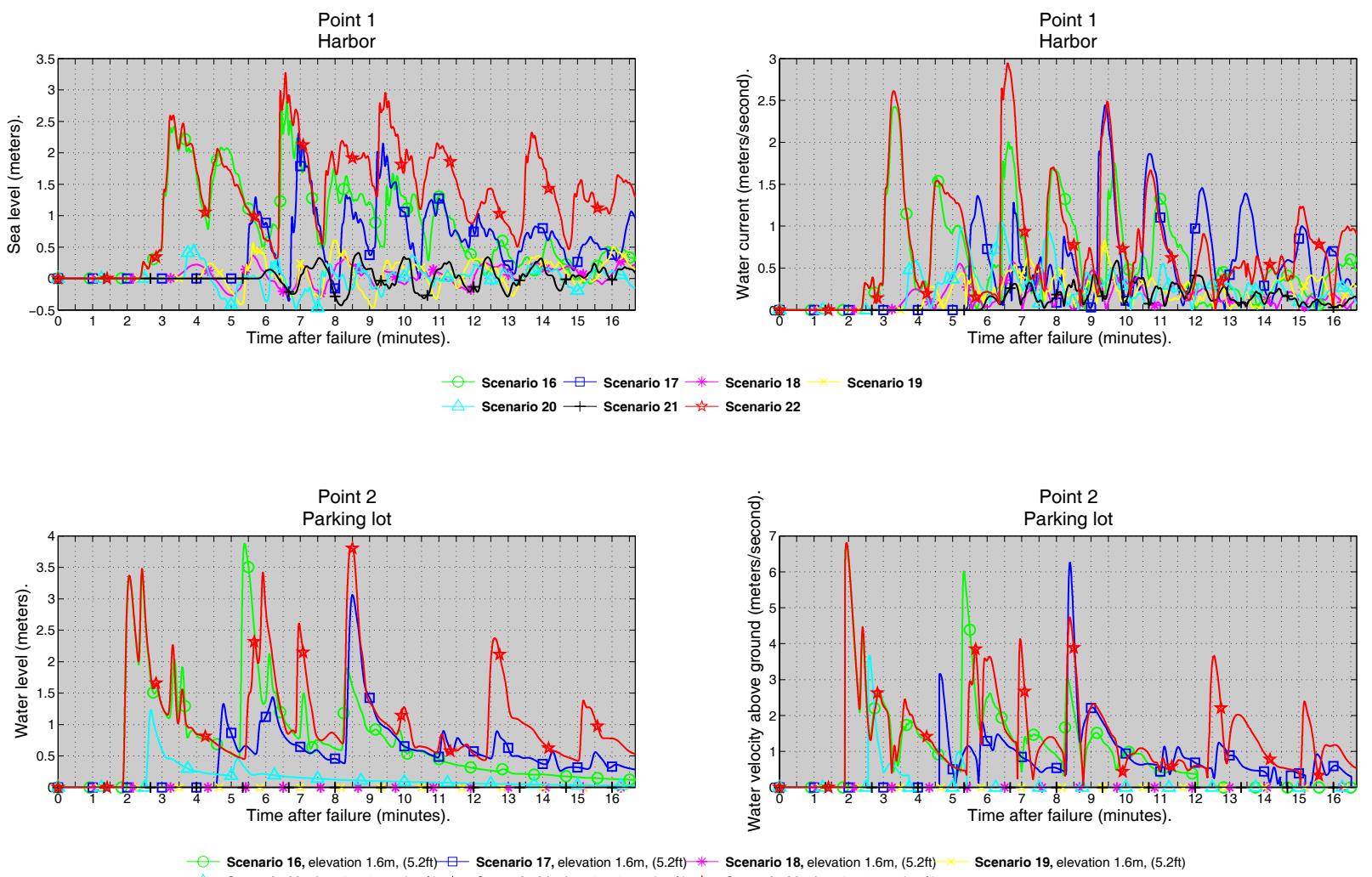

Scenario 16, elevation 1.6m, (5.2ft) $\square$ - Scenario 17, elevation $1.6 \mathrm{~m},(5.2 \mathrm{ft}) *$ Scenario 18 , elevation $1.6 \mathrm{~m},(5.2 \mathrm{ft})$ Scenario 20, elevation $1.6 \mathrm{~m},(5.2 \mathrm{ft})$ — Scenario 21 , elevation $1.6 \mathrm{~m},(5.2 \mathrm{ft})$ 슨 Scenario 22 , elevation $1.6 \mathrm{~m}$, (5.2ft)
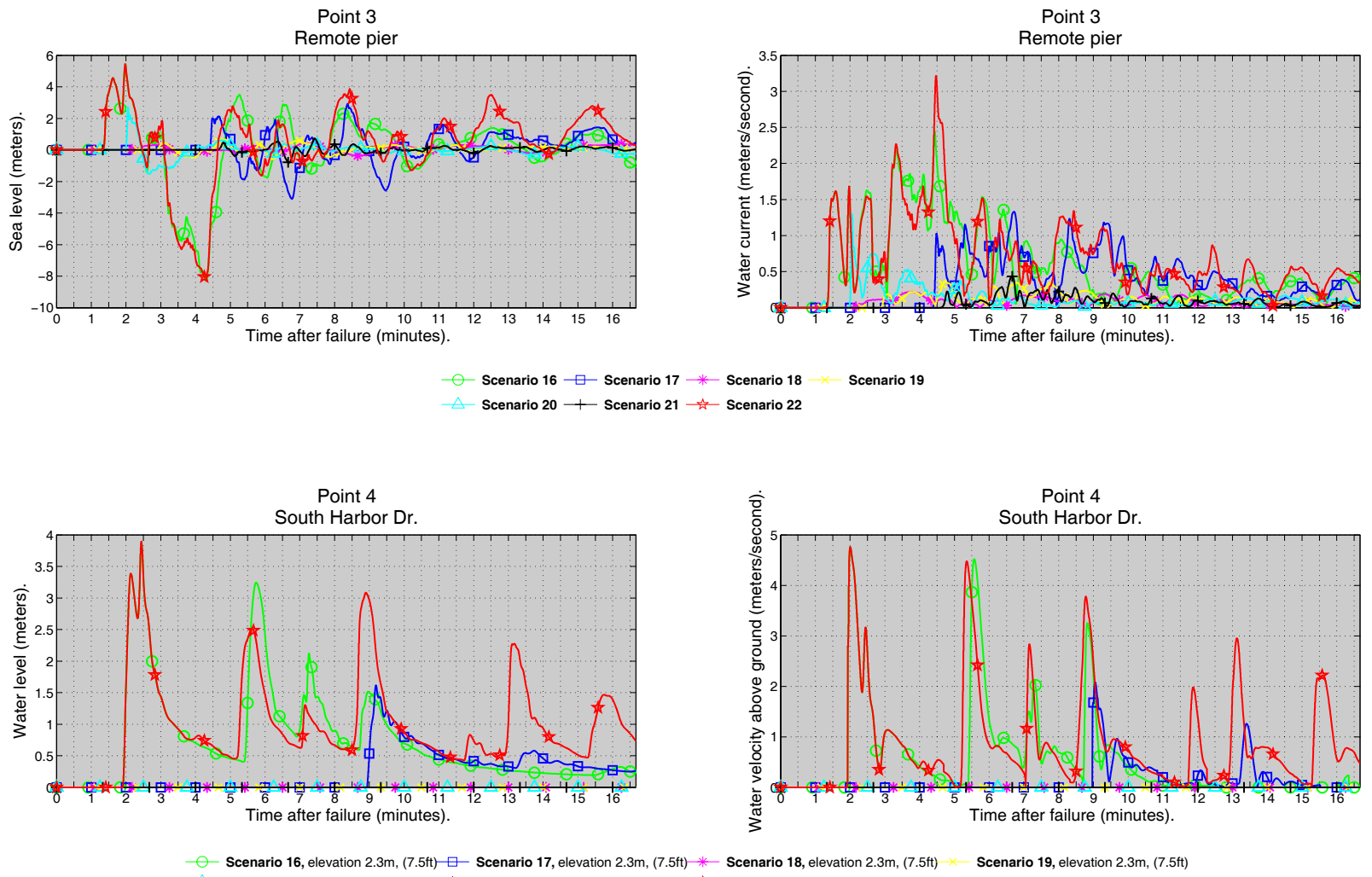

Scenario 16, elevation 2.3m, (7.5ft)- $\square$ Scenario 17, elevation 2.3m, (7.5ft) * Scenario 18, elevation 2.3m, (7.5ft) 

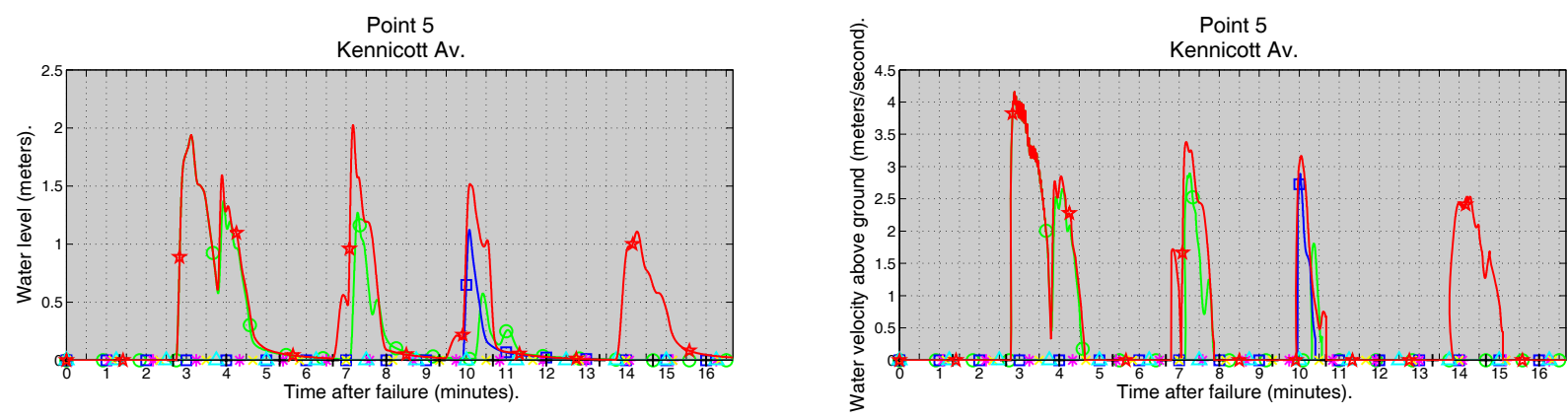

Scenario 16 , elevation $2.3 \mathrm{~m},(7.5 \mathrm{ft})-\square$ Scenario 17 , elevation $2.3 \mathrm{~m},(7.5 \mathrm{ft}) *$ Scenario 18 , elevation $2.3 \mathrm{~m},(7.5 \mathrm{ft})$ $\triangle$ Scenario 20, elevation 2.3m, (7.5ft) — Scenario 21, elevation 2.3m, (7.5ft) - Scenario 22, elevation $2.3 \mathrm{~m},(7.5 \mathrm{ft})$

Scenario 19, elevation 2.3m, (7.5t)

Point 6

Harbor parking

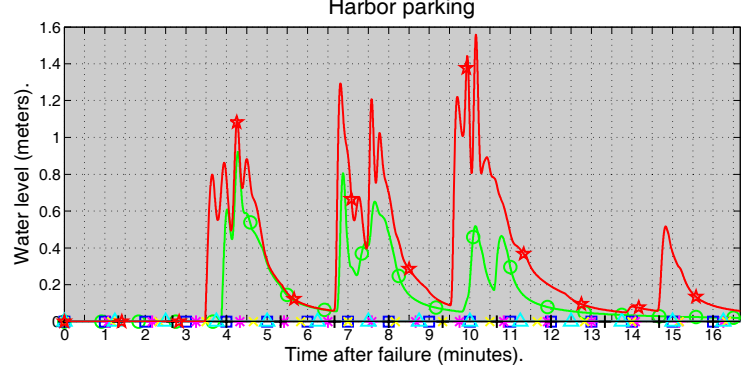

Scenario 16 , elevation $1.7 \mathrm{~m},(5.6 \mathrm{ft})-\square-$ Scenario 17 , elevation $1.7 \mathrm{~m},(5.6 \mathrm{ft})-*$

Scenario 20 , elevation $1.7 \mathrm{~m},(5.6 \mathrm{ft})-$ - Scenario 21 , elevation $1.7 \mathrm{~m},(5.6 \mathrm{ft})-($ )

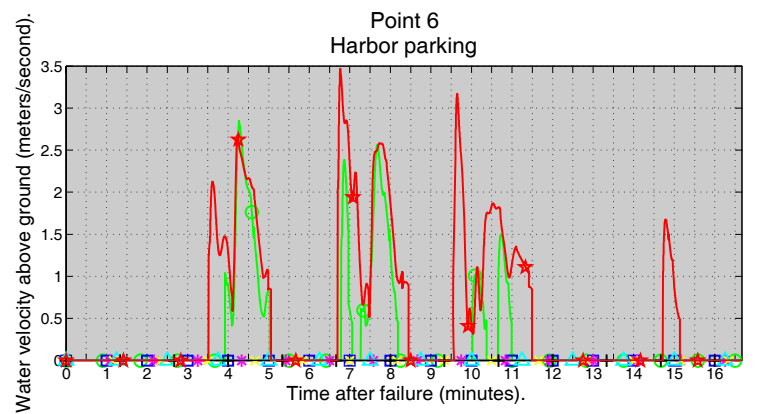

Scenario 19 , elevation $1.7 \mathrm{~m},(5.6 \mathrm{ft})$
Point 7

North Harbor Dr.

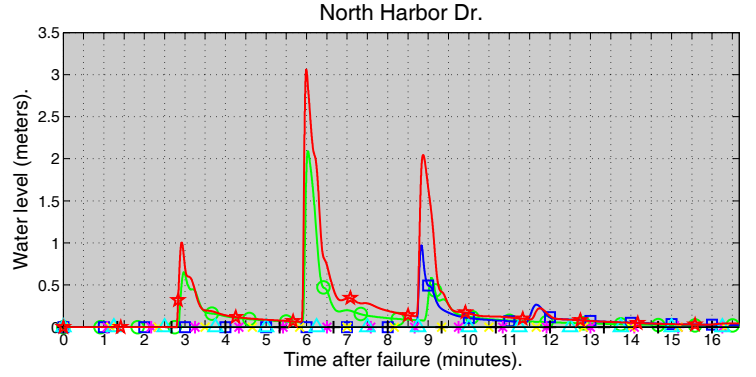

के $\quad$ Point 7

North Harbor Dr.

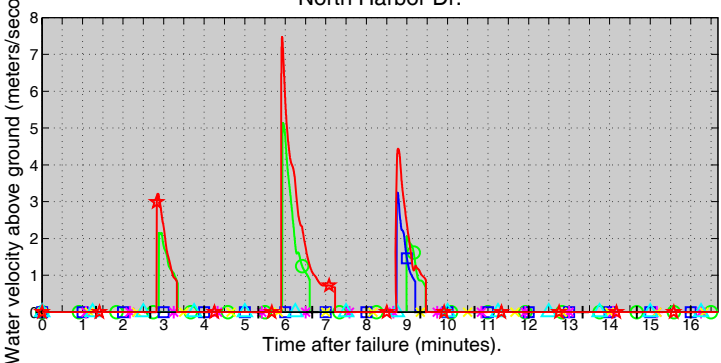

Scenario 16, elevation 3.4m, (11.1ft) $\square-$ Scenario 17, elevation 3.4m, (11.1ftt) * Scenario 18, elevation 3.4m, (11.1ft) Scenario 20, elevation $3.4 \mathrm{~m},(11.1 \mathrm{ft})-$ Scenario 21 , elevation $3.4 \mathrm{~m},(11.1 \mathrm{t})$

Scenario 19, elevation $3.4 \mathrm{~m},(11.1 \mathrm{ft})$

Point 8

Ferry terminal

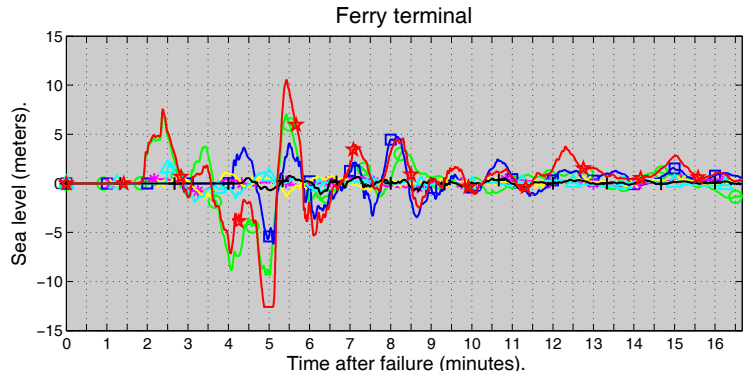

Point 8

Ferry terminal

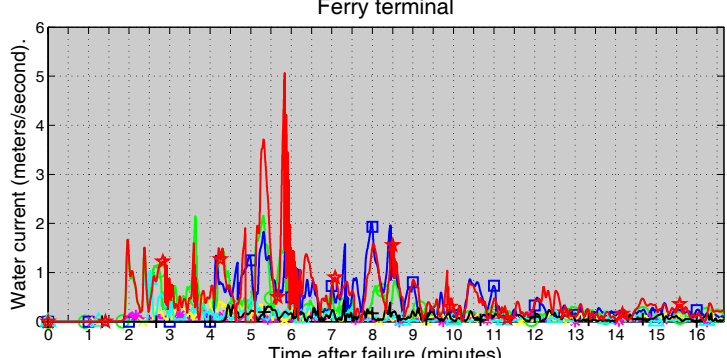

$$
\begin{aligned}
& \text { Scenario } 16 \square \text { Scenario } 17 \rightarrow \text { Scenario } 18 \div \text { Scenario } 19 \\
& \triangle \text { Scenario } 20 \div \text { Scenario } 21 \rightarrow-\text { Scenario } 22
\end{aligned}
$$



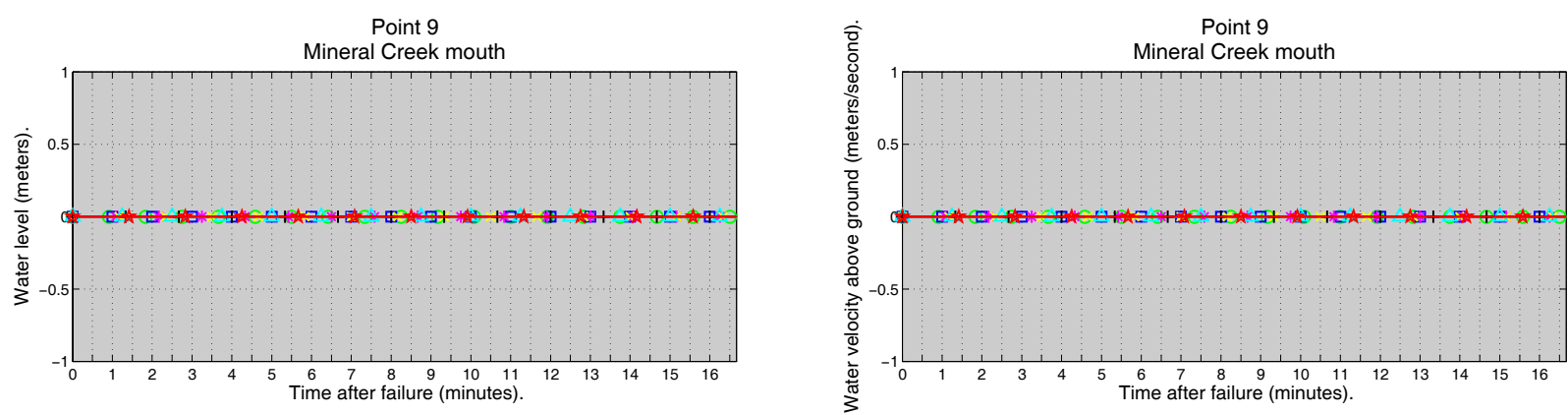

Scenario 16, elevation $4.8 \mathrm{~m},(15.7 \mathrm{ft})-\square$ Scenario 17 , elevation $4.8 \mathrm{~m}$, (15.7ft) $*$ * Scenario 20 , elevation $4.8 \mathrm{~m},(15.7 \mathrm{tt})$ — Scenario 21 , elevation $4.8 \mathrm{~m},(15.7 \mathrm{ft})$,

Scenario 18 , elevation $4.8 \mathrm{~m},(15.7 \mathrm{ft})$

Scenario 19, elevation $4.8 \mathrm{~m},(15.7 \mathrm{ft})$

Point 10

Cabins

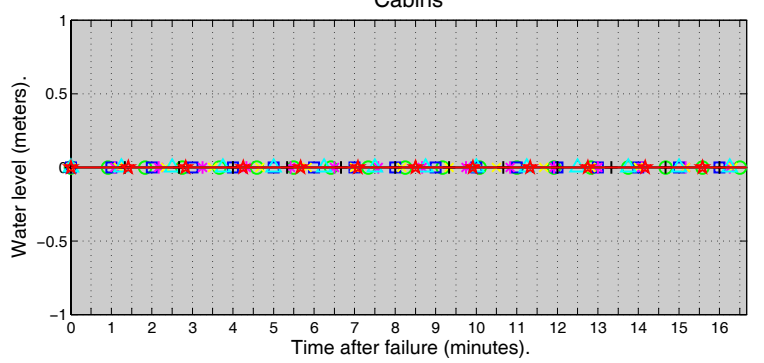

Scenario 16, elevation $4.7 \mathrm{~m},(15.4 \mathrm{ft})-\square$ Scenario 17 , elevation $4.7 \mathrm{~m},(15.4 \mathrm{ft}) *$

- Scenario 20 , elevation $4.7 \mathrm{~m},(15.4 \mathrm{ft})$ - - Scenario 21 , elevation $4.7 \mathrm{~m}$, (15.4t)

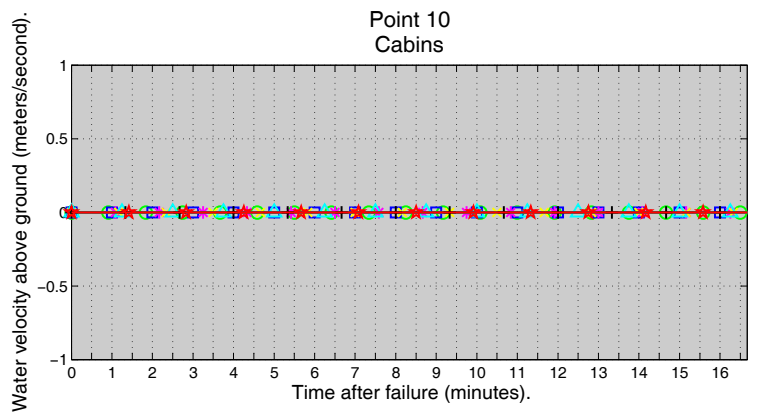

Scenario 19, elevation $4.7 \mathrm{~m},(15.4 \mathrm{ft})$
Point 11

Fidalgo Av.

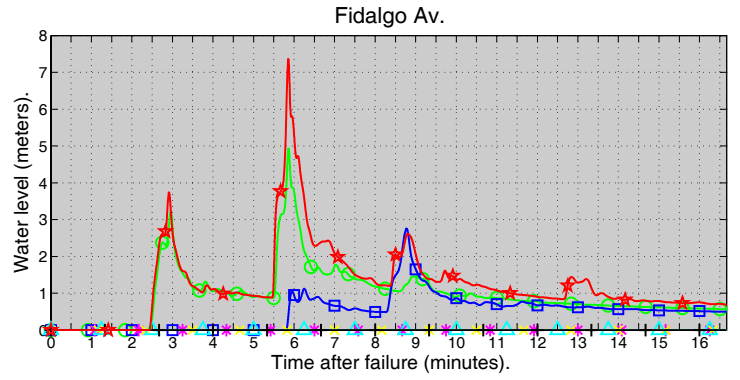

Scenario 16, elevation $2.8 \mathrm{~m},(9.2 \mathrm{ft})-\square-$ Scenario 17 , elevation $2.8 \mathrm{~m},(9.2 \mathrm{ft}) *$

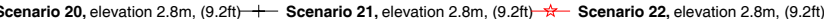

Point 12

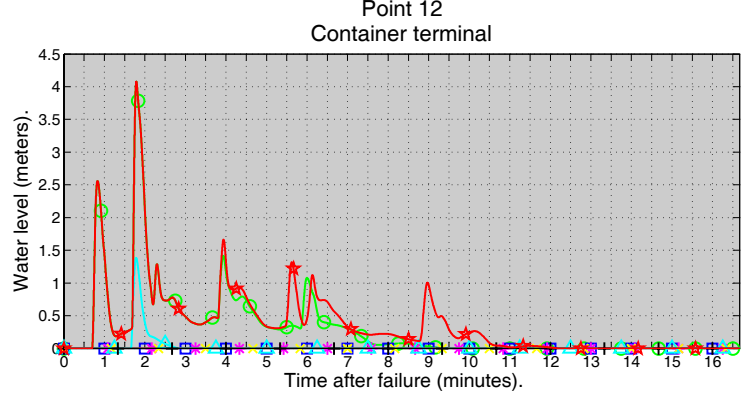

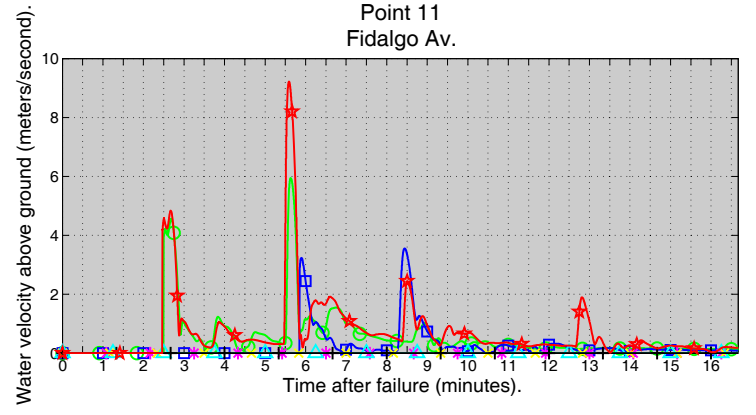

Scenario 19, elevation $2.8 \mathrm{~m},(9.2 \mathrm{ft})$

Point 12

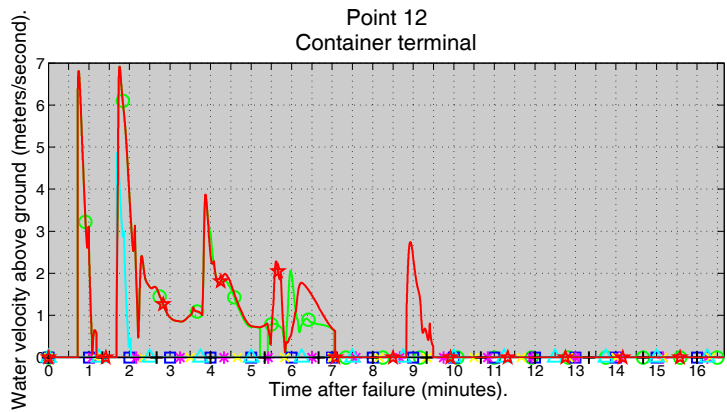

Scenario 16, elevation 3.1m, (10.2ft) - Scenario 17, elevation $3.1 \mathrm{~m},(10.2 \mathrm{ft}) *$ Scenario 18, elevation $3.1 \mathrm{~m},(10.2 \mathrm{ft})$ Scenario 20, elevation 3.1m, (10.2ft) — Scenario 21, elevation 3.1m, (10.2ft) $\frac{\text { ht }}{\mathrm{m}}$ Scenario 22, elevation $3.1 \mathrm{~m},(10.2 \mathrm{ft})$

Scenario 19, elevation $3.1 \mathrm{~m},(10.2 \mathrm{ft})$ 

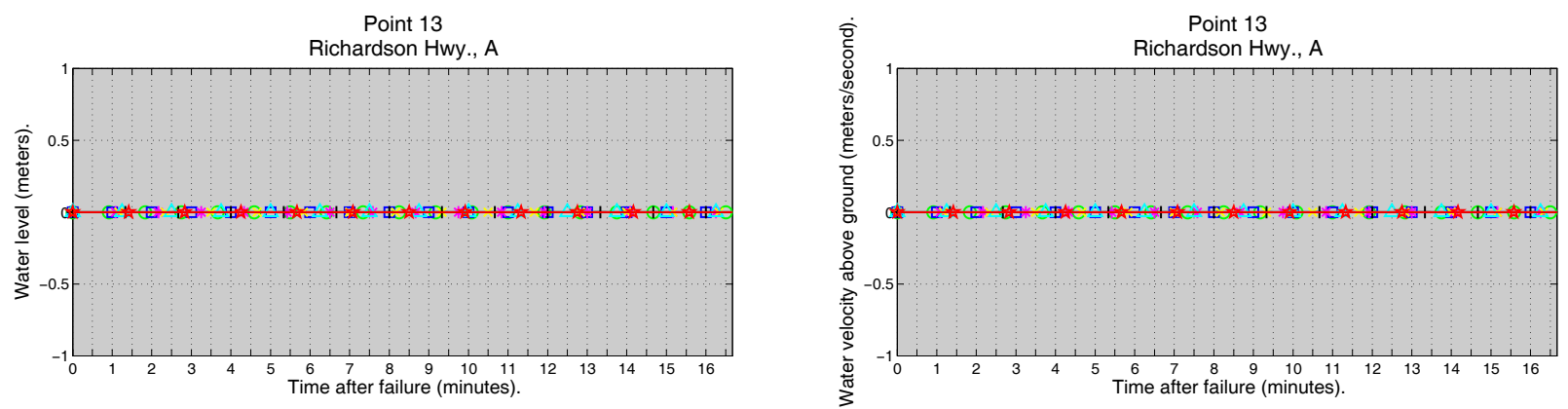

Scenario 16, elevation $2.7 \mathrm{~m},(8.9 \mathrm{ft}) \square-$ Scenario 17 , elevation $2.7 \mathrm{~m}$, (8.9ft) $*$ - Scenario 18 , elevation $2.7 \mathrm{~m}$, (8.9ft) Scenario 20, elevation 2.7m, (8.9ft) । Scenario 21, elevation 2.7m, (8.9ft)

Scenario 19, elevation $2.7 \mathrm{~m},(8.9 \mathrm{ft})$

Point 14

Richardson Hwy., B

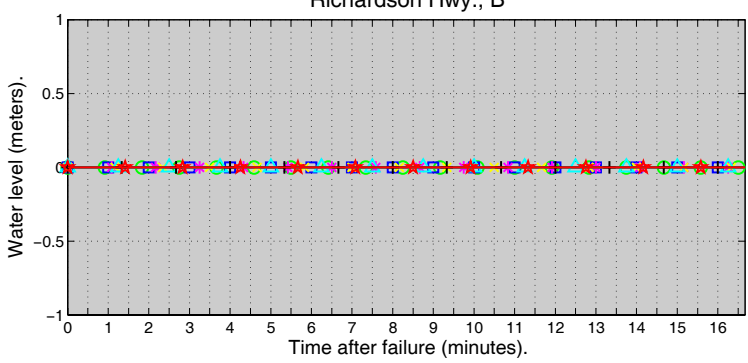

Point 14

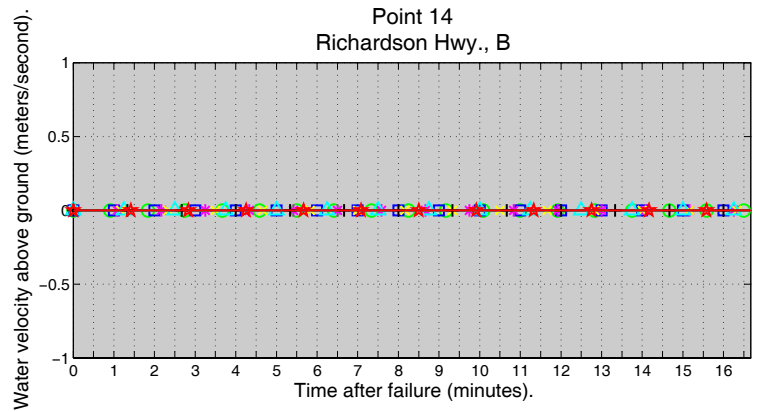

Scenario 19, elevation $2.4 \mathrm{~m},(7.9 \mathrm{ft})$

Scenario 16, elevation 2.4m, (7.9ft)- - - Scenario 17, elevation 2.4m, (7.9ft) - * - Scenario 18, elevation 2.4m, (7.9ft) Scenario 20, elevation $2.4 \mathrm{~m},(7.9 \mathrm{ft})-$ Scenario 21, elevation $2.4 \mathrm{~m},(7.9 \mathrm{ft})-$ Scenario 22, elevation $2.4 \mathrm{~m},(7.9 \mathrm{ft})$
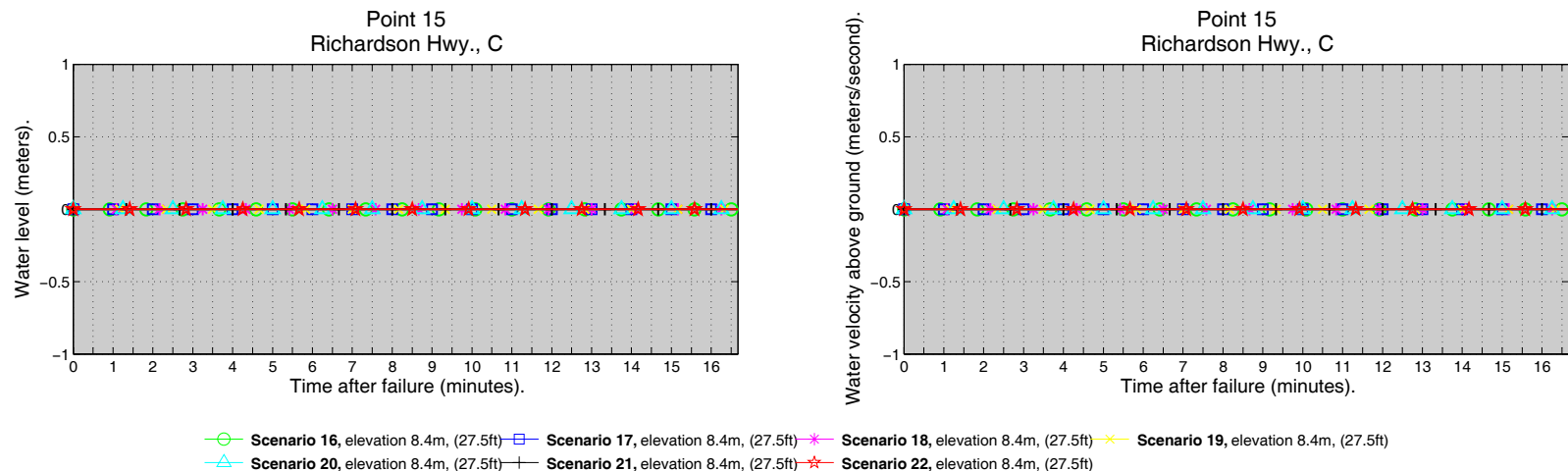

Point 16

Richardson Hwy., D
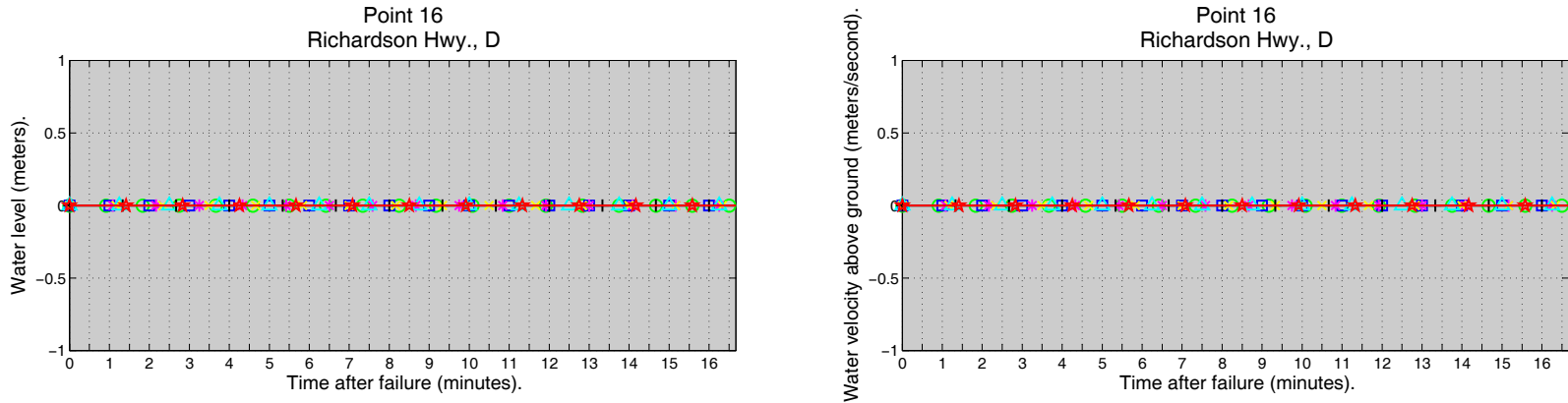

Scenario 16, elevation $12.4 \mathrm{~m},(40.7 \mathrm{ft}) \square-$ Scenario 17 , elevation $12.4 \mathrm{~m},(40.7 \mathrm{ft}) *$ Scenario 18, elevation $12.4 \mathrm{~m},(40.7 \mathrm{ft})$ Scenario 20, elevation $12.4 \mathrm{~m},(40.7 \mathrm{tt}$ - - Scenario 21, elevation $12.4 \mathrm{~m},(40.7 \mathrm{tt})-$ Scenario 22 , elevation $12.4 \mathrm{~m},(40.7 \mathrm{tt})$ 

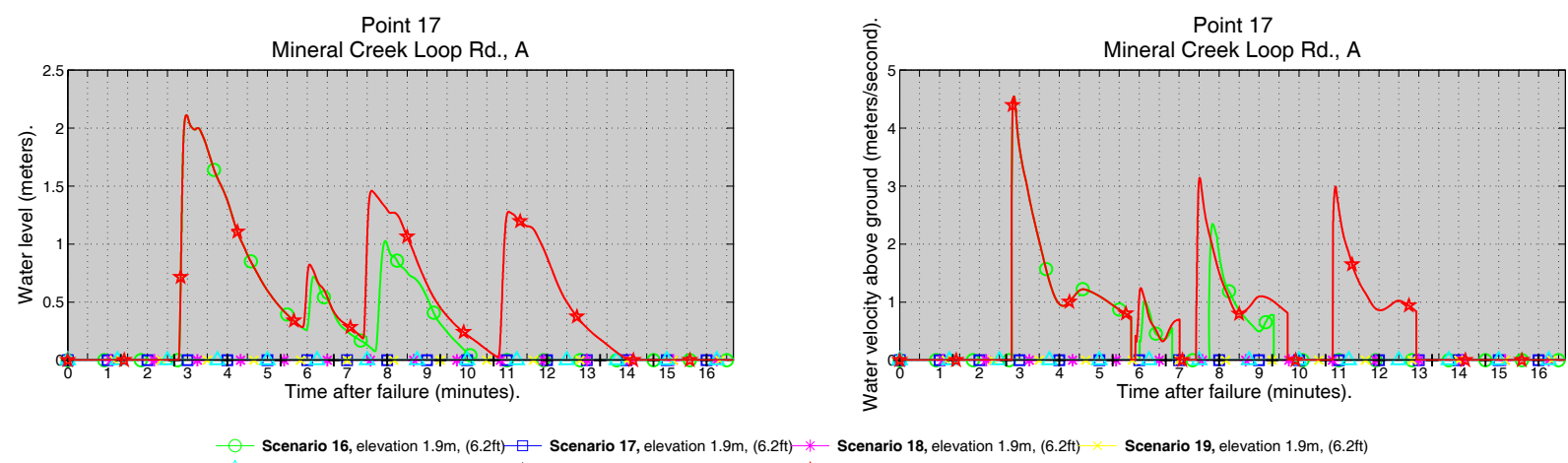

Scenario 16 , elevation $1.9 \mathrm{~m},(6.2 \mathrm{ft}) \square-$ Scenario 17 , elevation $1.9 \mathrm{~m}$, (6.2ft)Scenario 20, elevation 1.9m, (6.2ft) - Scenario 21, elevation 1.9m, (6.2ft) $\frac{h}{\mathrm{n}}$ - Scenario 22, elevation 1.9m, (6.2ft)
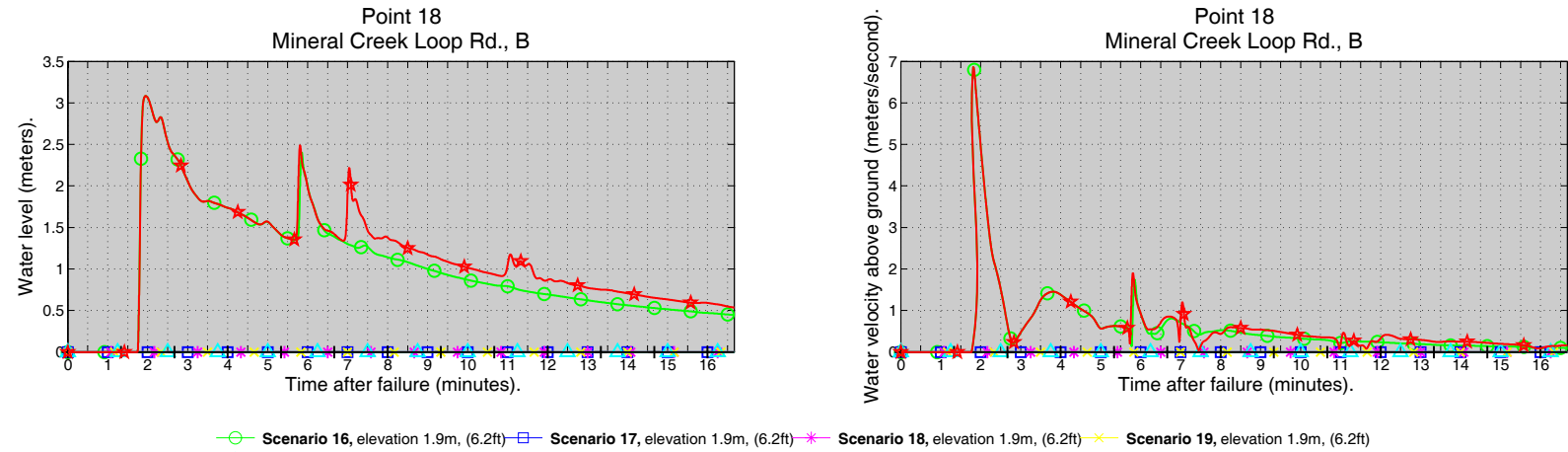

Scenario 16, elevation 1.9m, (6.2ft) - - Scenario 17, elevation $1.9 \mathrm{~m},(6.2 \mathrm{tt})-2$ Scenario 20, elevation 1.9m, (6.2ft) - Scenario 21, elevation $1.9 \mathrm{~m},(6.2 \mathrm{ft})-\frac{1}{\mathrm{~h}}$ - Scenario 22, elevation $1.9 \mathrm{~m},(6.2 \mathrm{ft})$
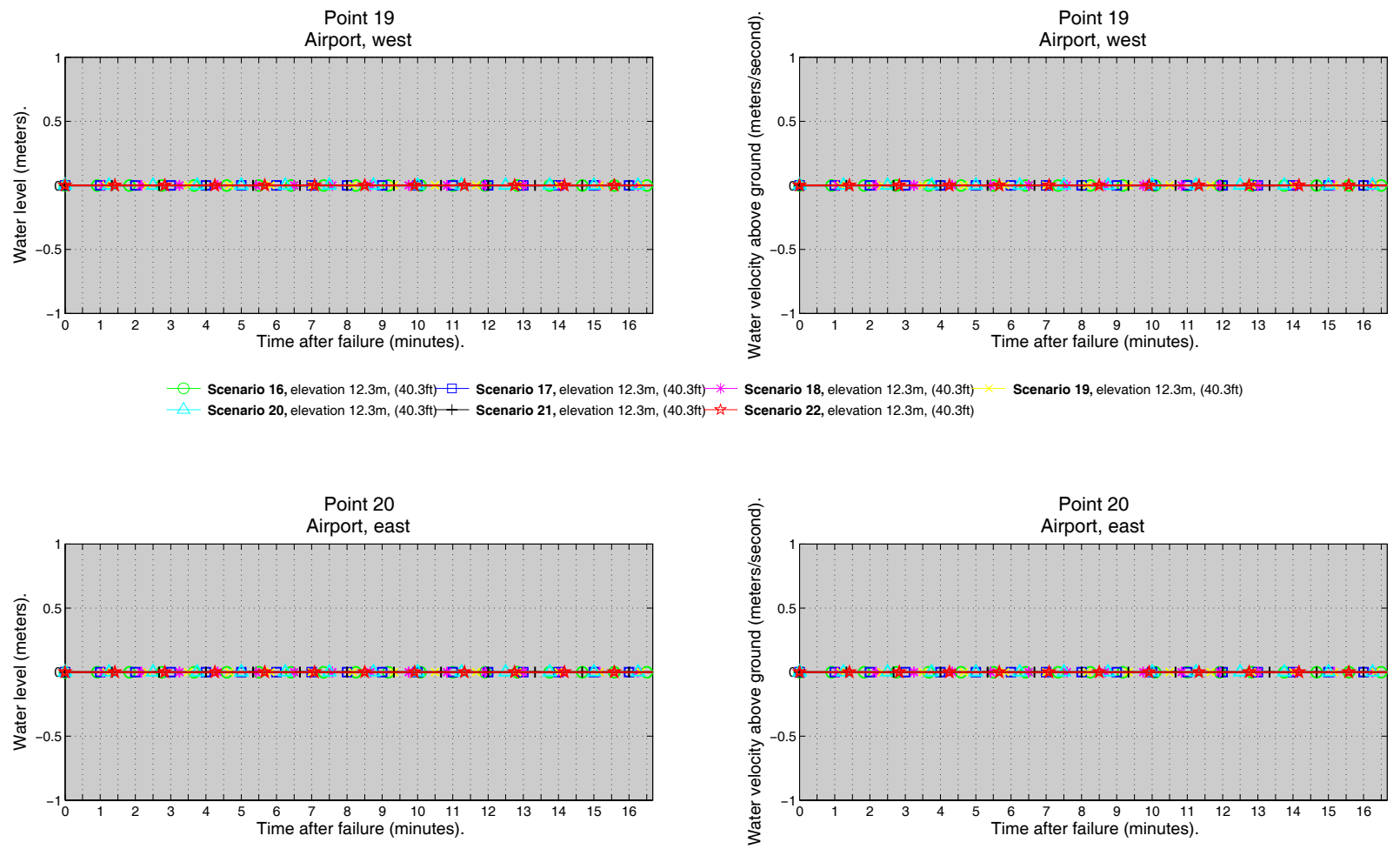

Scenario 16, elevation 35.8m, (117.4ft) $\square$ Scenario 17, elevation 35.8m, (117.4ft) $*$ Scenario 18, elevation 35.8m, (117.4ft) Scenario 20, elevation 35.8m, (117.4ft) — Scenario 21, elevation 35.8m, (117.4ft) $\frac{h}{h}$ - Scenario 22, elevation 35.8m, (117.4ft)

Scenario 19, elevation 35.8m, (117.4ft) 

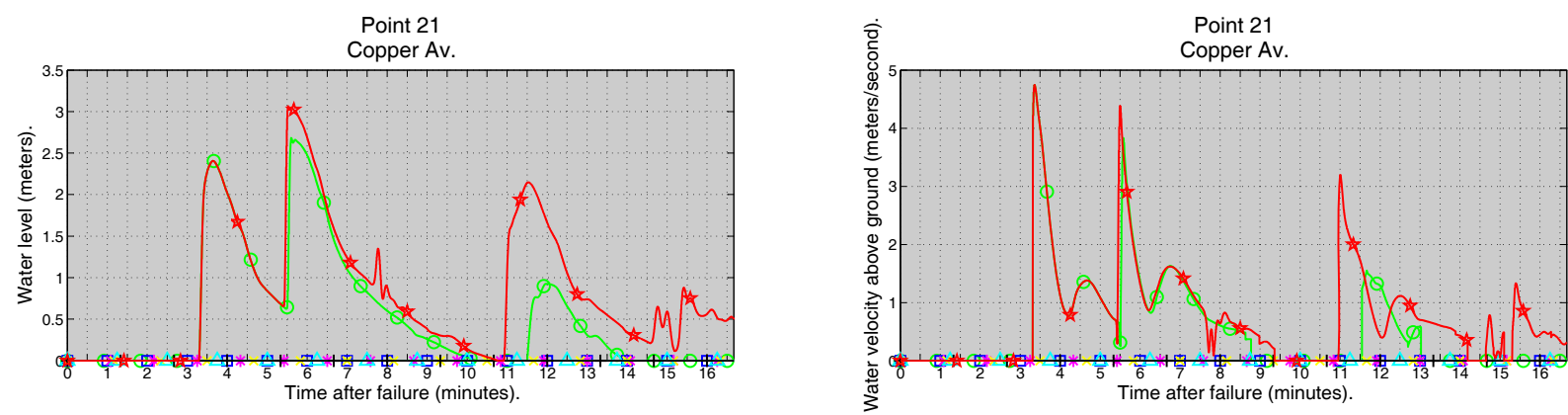

Scenario 16, elevation 1.3m, (4.3ft)- - Scenario 17, elevation 1.3m, (4.3ft) * Scenario 18, elevation 1.3m, (4.3ft) Scenario 20, elevation 1.3m, (4.3ft) - Scenario 21, elevation 1.3m, (4.3ft) - st- Scenario 22, elevation 1.3m, (4.3ft)
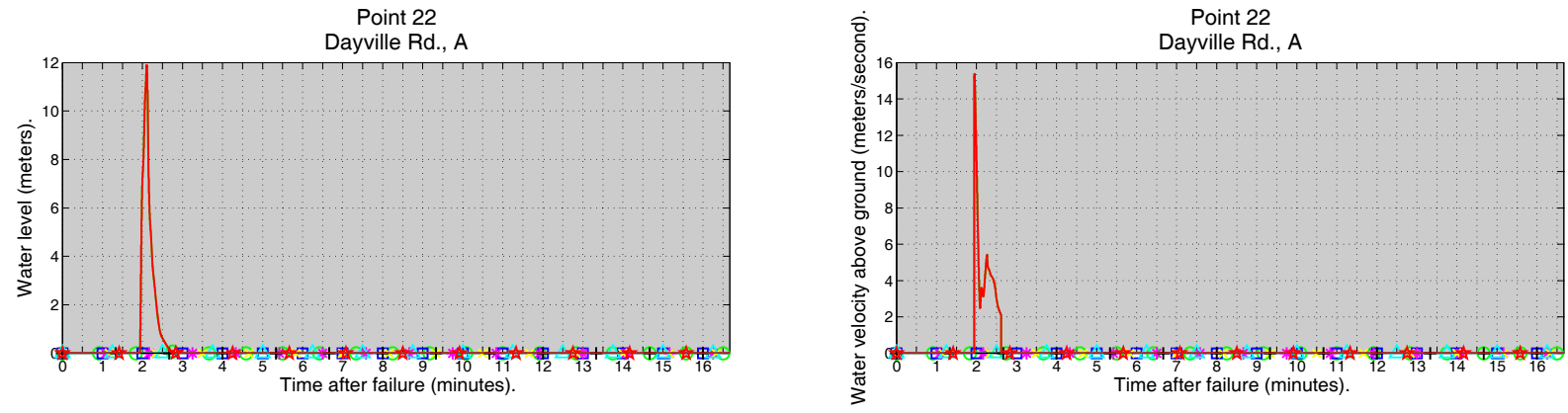

Scenario 16, elevation 10.5m, (34.4ft) $\square$ - Scenario 17, elevation 10.5m, (34.4ft) * - Scenario 18, elevation 10.5m, (34.4ft)

Scenario 19 , elevation $10.5 \mathrm{~m},(34.4 \mathrm{ft})$

Point 23

Dayville Rd., B

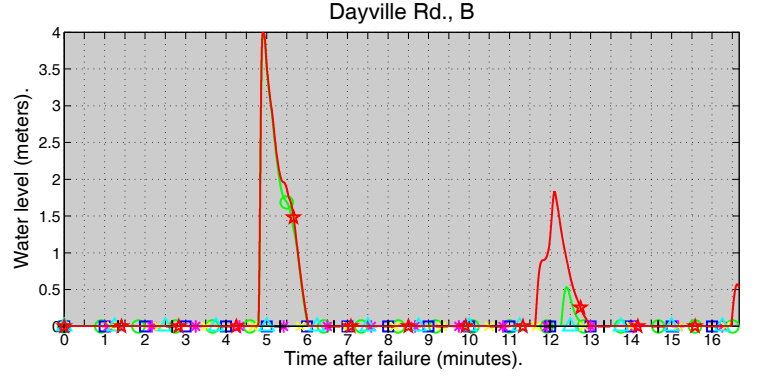

Scenario 16, elevation $2.5 \mathrm{~m},(8.2 \mathrm{ft}) \square$ - Scenario 17, elevation $2.5 \mathrm{~m},(8.2 \mathrm{ft}) *$ - Scenario 18, elevation $2.5 \mathrm{~m},(8.2 \mathrm{ft})$ Scenario 20, elevation 2.5m, (8.2ft)- - Scenario 21, elevation 2.5m, (8.2ft) 每- Scenario 22, elevation 2.5m, (8.2ft)

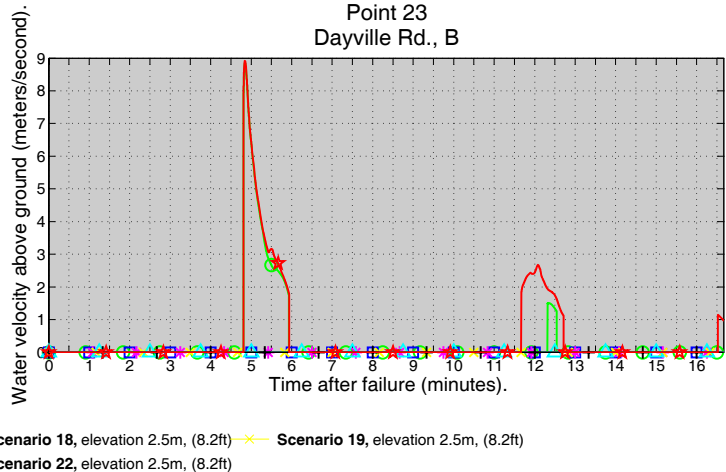

Point 24

Point 24

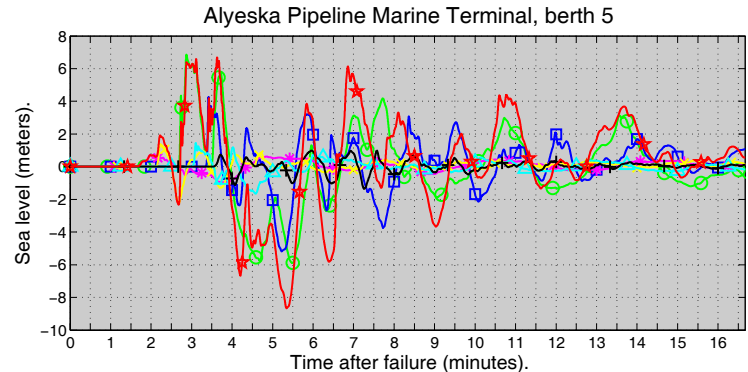

Scenario $16 \square$ Scenario $17 *$ Scenario 18

$\triangle$ Scenario $20 \leftarrow$ Scenario $21-\not \rightarrow$ Scenario 22

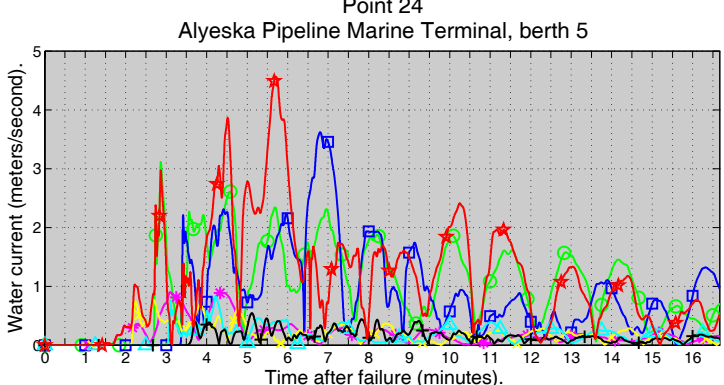

Scenario 19 

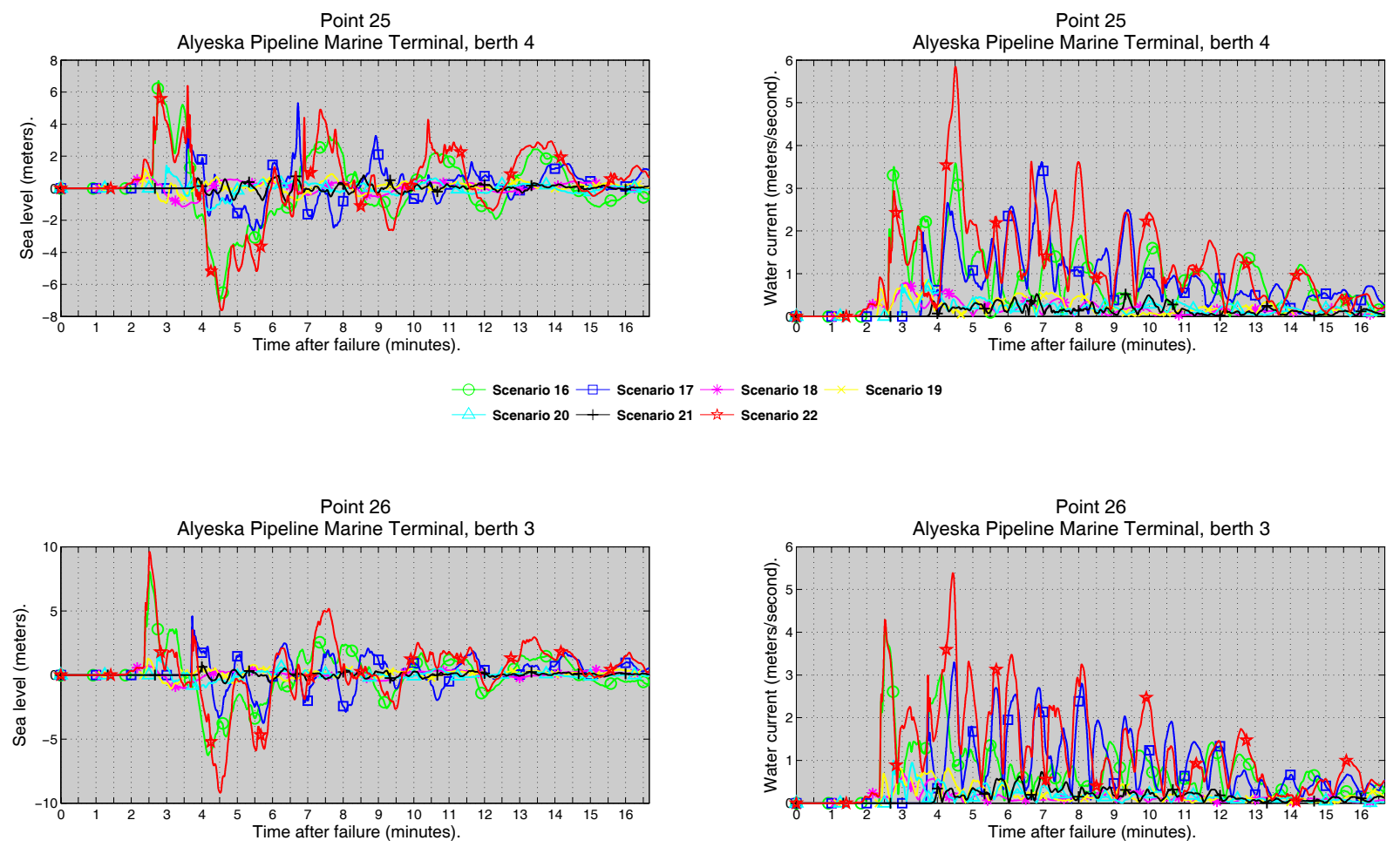

$$
\begin{aligned}
& - \text { Scenario } 16 \square \text { Scenario } 17 \rightarrow \text { Scenario } 18 \quad \text { Scenario } 19 \\
& \triangle \text { Scenario } 20 \div \text { Scenario } 21 \rightarrow-\text { Scenario } 22
\end{aligned}
$$

Point 27

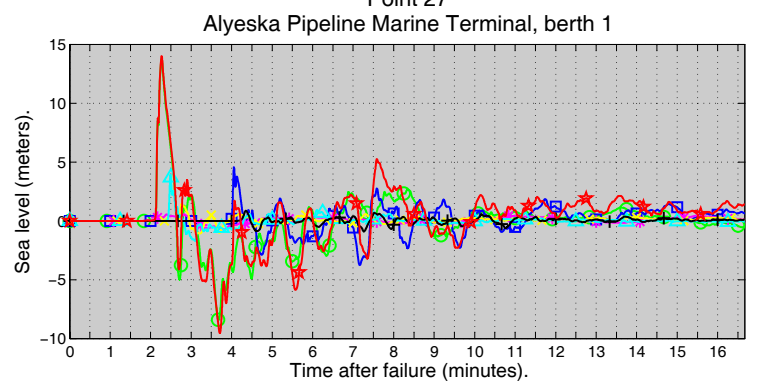

- Scenario $16-$ Scenario $17 \rightarrow$ Scenario 18

Point 28

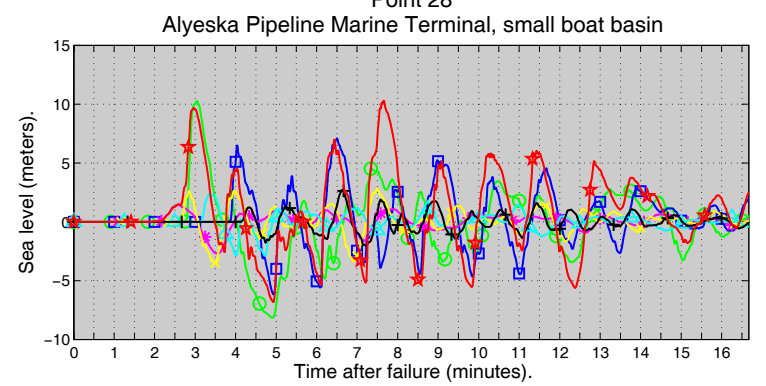

Scenario $16 \square$ Scenario $17 *$ Scenario 18

$\triangle$ Scenario $20 \leftarrow$ Scenario $21 \rightarrow \frac{\lambda}{M}$ Scenario 2
Point 27

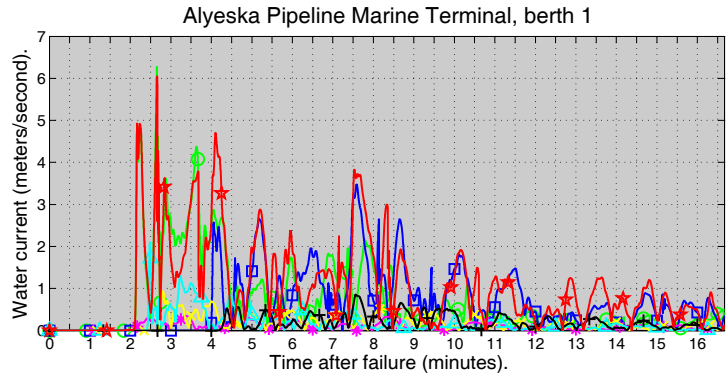

Scenario 19 

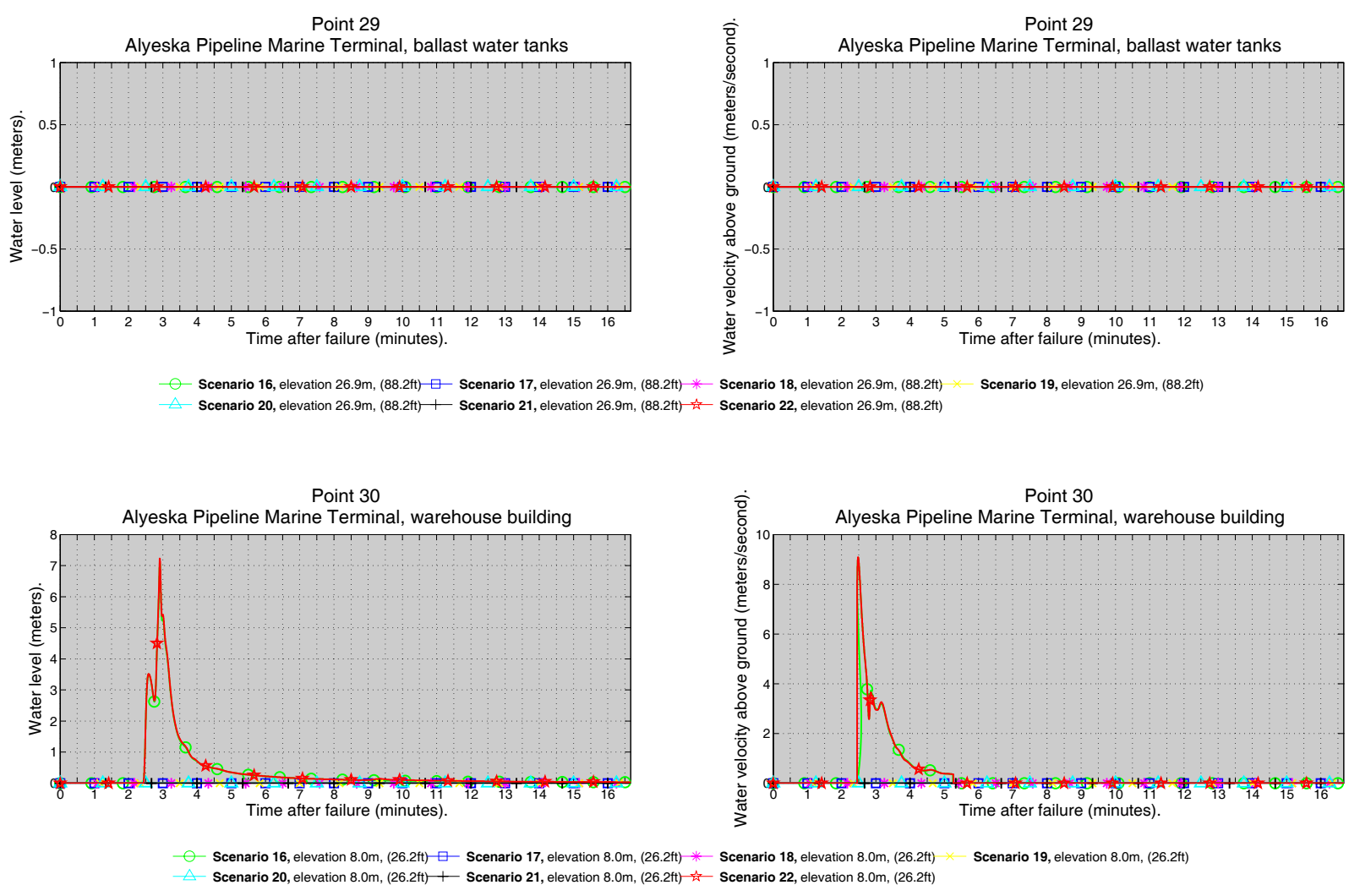

Point 31
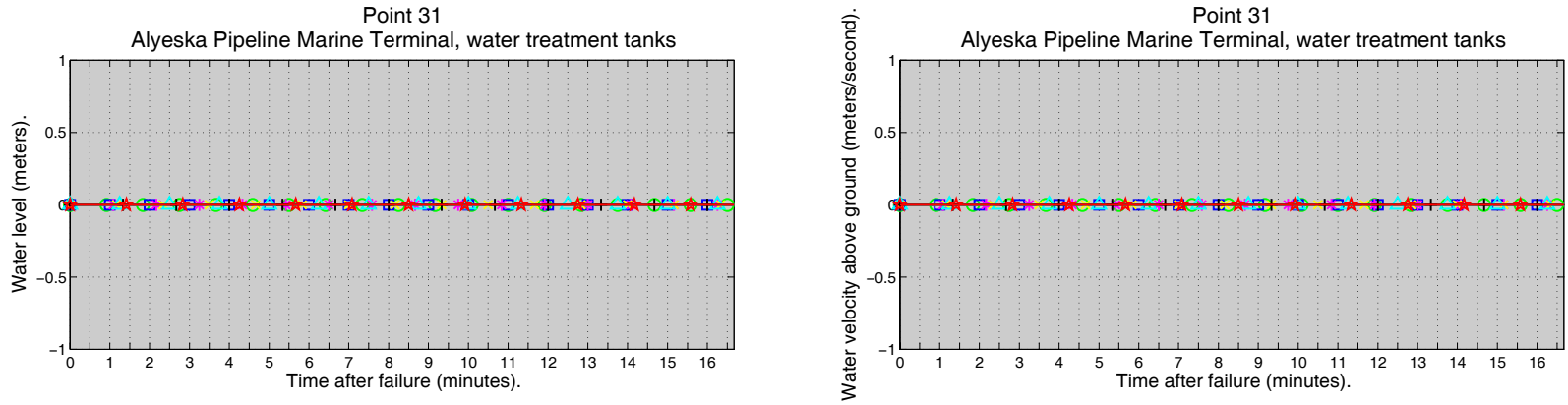

Scenario 16, elevation 12.4m, (40.7ft) $\square$ Scenario 17, elevation 12.4m, (40.7ft) $*$ - Scenario 18, elevation 12.4m, (40.7ft)

Scenario 19, elevation $12.4 \mathrm{~m},(40.7 \mathrm{ft})$ Scenario 20, elevation $12.4 \mathrm{~m},(40.7 \mathrm{ft})-1$ Scenario 21, elevation $12.4 \mathrm{~m},(40.7 \mathrm{ft})$ 岁 Scenario 22, elevation $12.4 \mathrm{~m},(40.7 \mathrm{ft})$

Point 32

Petro Star Valdez refinery

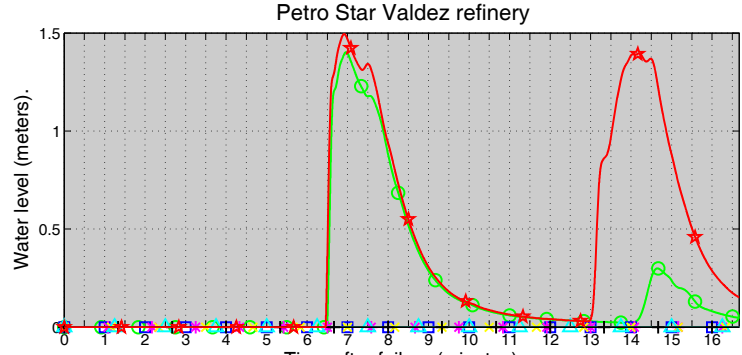

Time after failure (minutes)

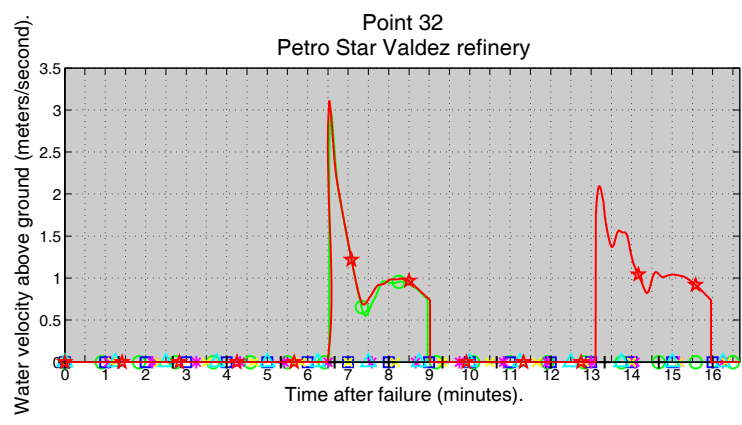

Scenario 19 , elevation $1.4 \mathrm{~m},(4.6 \mathrm{ft})$

Scenario 16, elevation 1.4m, (4.6ft) $\square$ Scenario 17, elevation 1.4m, (4.6ft) $*$ Scenario 18, elevation 1.4m, (4.6ft) Scenario 20, elevation 1.4m, (4.6ft) — Scenario 21, elevation 1.4m, (4.6ft) 每- Scenario 22, elevation 1.4m, (4.6ft) 

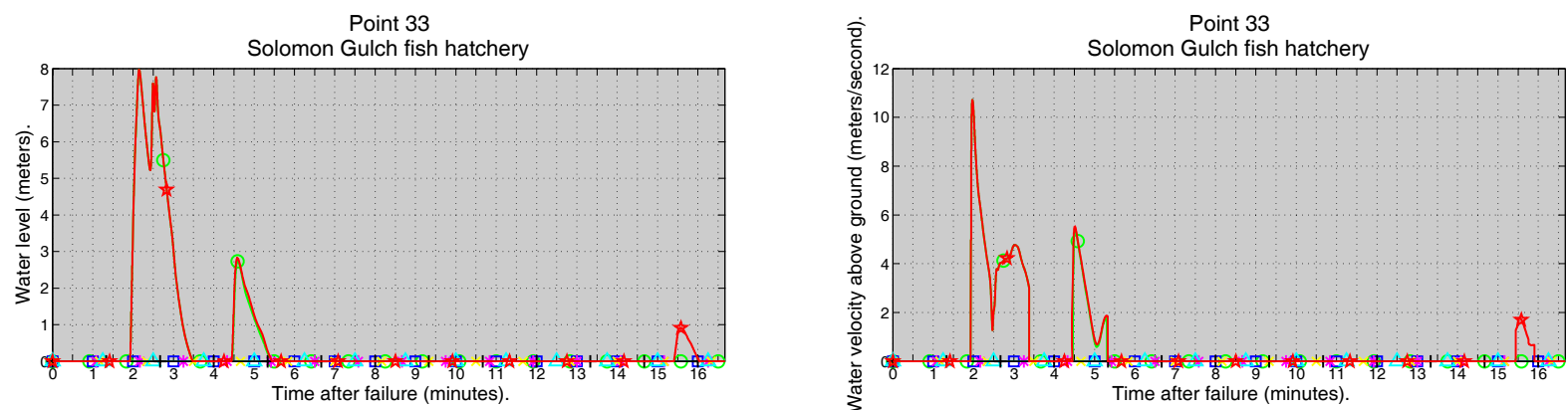

Scenario 16, elevation $3.3 \mathrm{~m},(10.8 \mathrm{ft})-\square-$ Scenario 17 , elevation $3.3 \mathrm{~m},(10.8 \mathrm{ft})-$ * Scenario 18 , elevation $3.3 \mathrm{~m},(10.8 \mathrm{ft})$ Scenario 20, elevation $3.3 \mathrm{~m},(10.8 \mathrm{ft})-$ Scenario 21 , elevation $3.3 \mathrm{~m},(10.8 \mathrm{ft})$ 出 - Scenario 22, elevation $3.3 \mathrm{~m}$, (10.8ft)
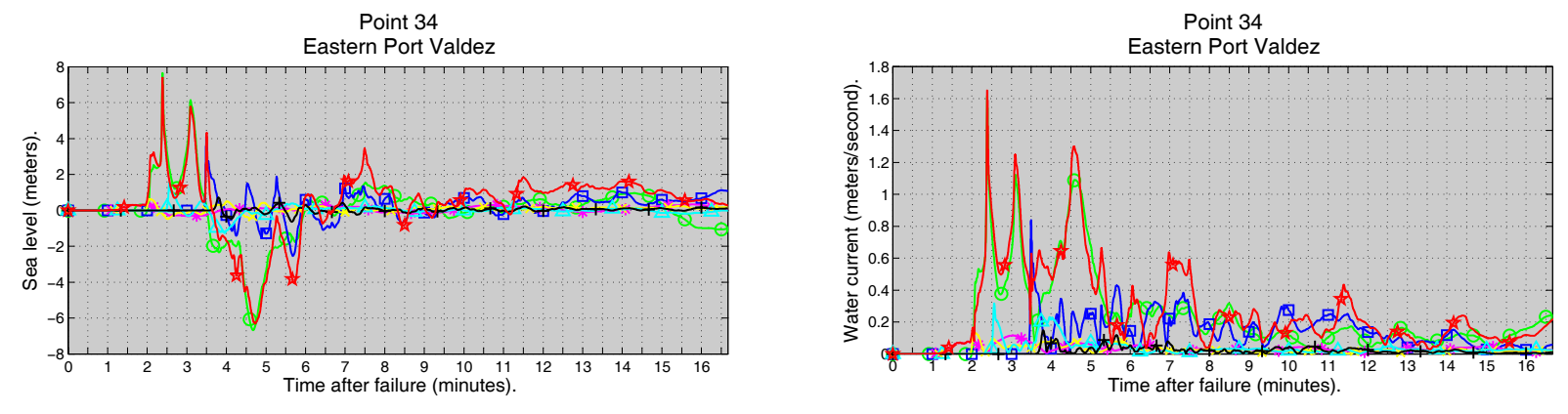

$$
\begin{aligned}
& - \text { Scenario } 16 \rightarrow \text { Scenario } 17 \rightarrow \text { Scenario } 18 \div \text { Scenario } 19 \\
& \square \text { Scenario } 20 \div \text { Scenario } 21 \rightarrow \text { Scenario } 22
\end{aligned}
$$
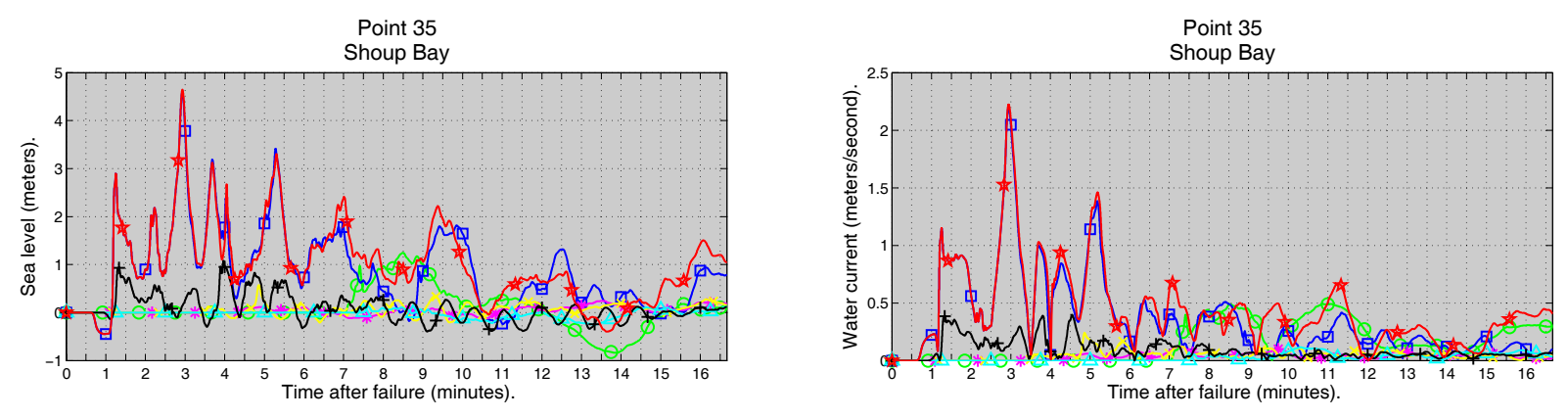

$$
\begin{aligned}
& \text { Scenario } 16-\text { Scenario } 17 \rightarrow-\text { Scenario } 18 \div \text { Scenario } 19 \\
& \triangle \text { Scenario } 20 \div \text { Scenario } 21 \rightarrow \text { Scenario } 22
\end{aligned}
$$
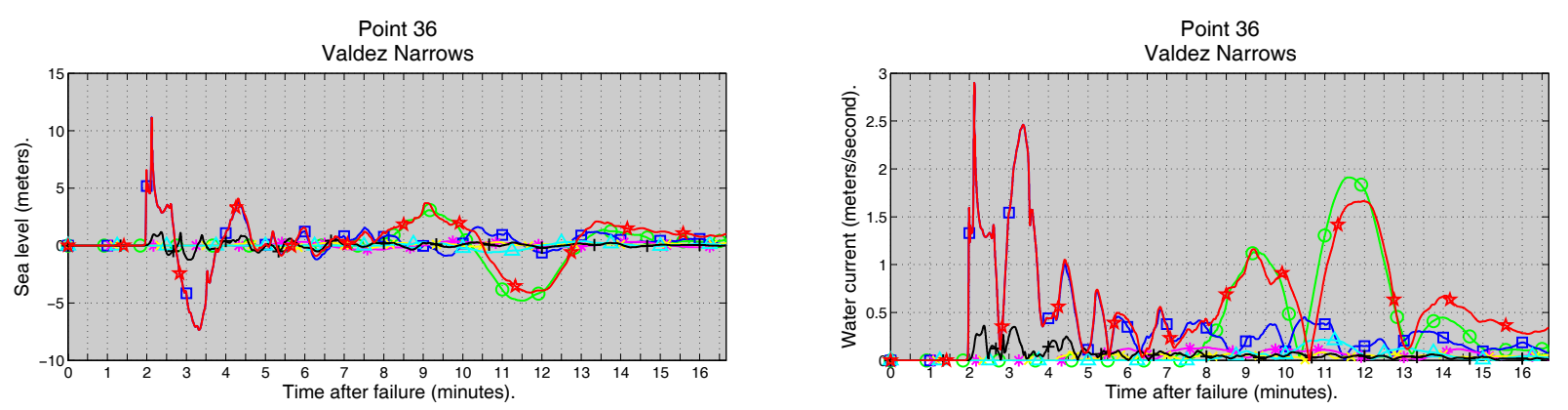

$$
\begin{aligned}
& \text { Scenario } 16-\text { Scenario } 17-\text { Scenario } 18 \quad \text { Scenario } 19 \\
& \triangle \text { Scenario } 20 \div \text { Scenario } 21-\frac{\psi}{h} \text { Scenario } 22
\end{aligned}
$$




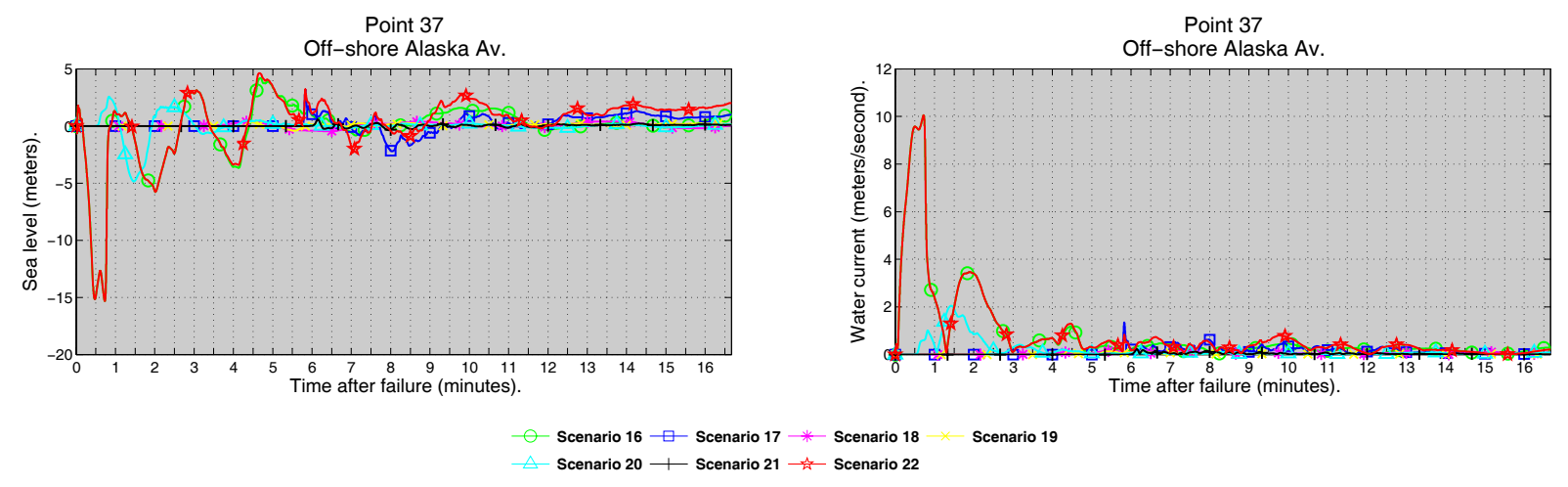

Point 38

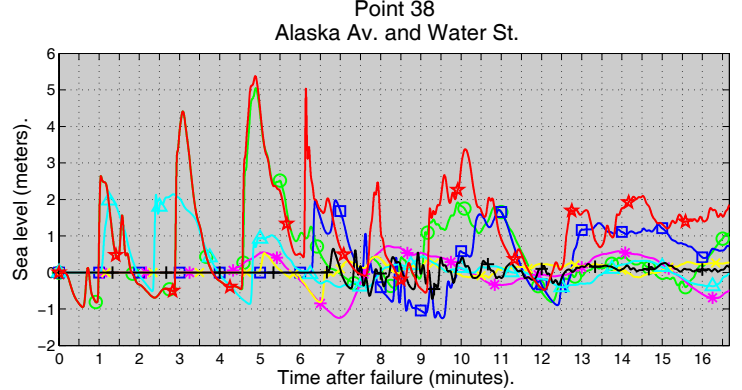

Point 38

Alaska Av. and Water St.

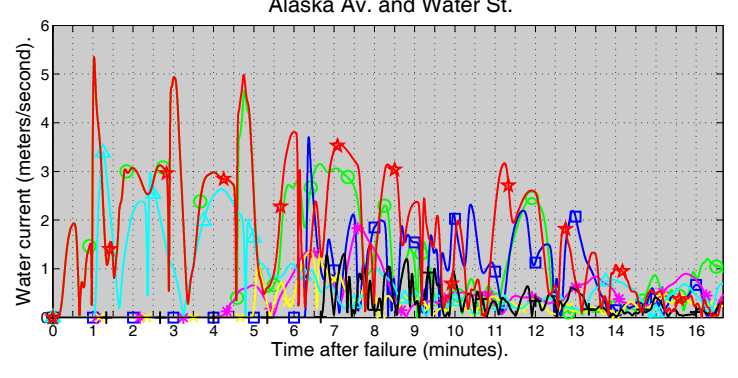

Scenario 19
Point 39

Alaska Av. and McKinley St.

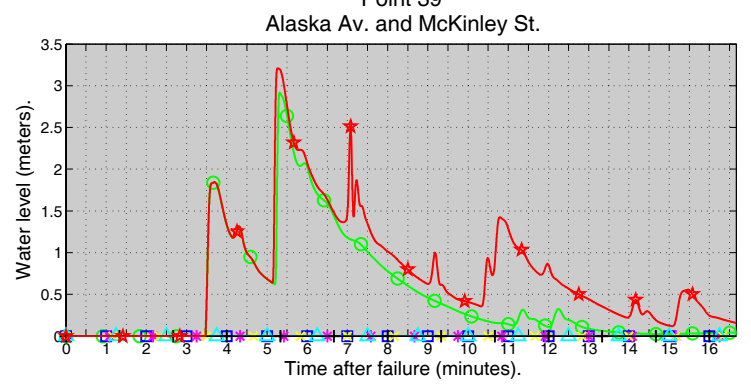

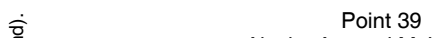

Alaska Av. and McKinley St.

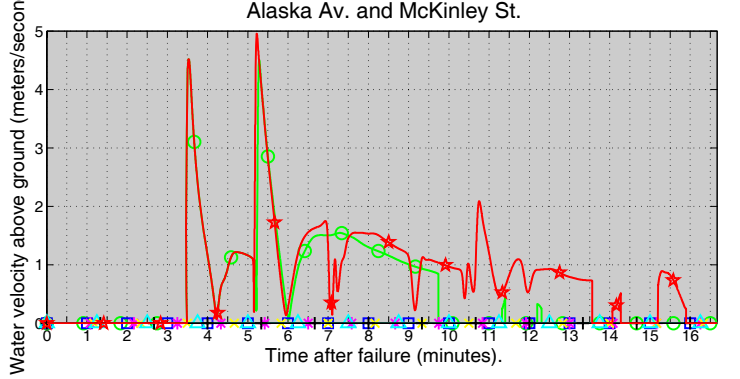

Scenario 16, elevation $1.5 \mathrm{~m},(4.9 \mathrm{ft})-\square$ Scenario 17 , elevation $1.5 \mathrm{~m},(4.9 \mathrm{ft}) *$ Scenario 18, elevation $1.5 \mathrm{~m},(4.9 \mathrm{ft})$

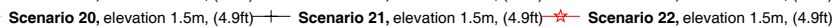




\section{Figure A-3}

Time series of water level and velocity at selected locations for scenarios 1, 3, 6, and 14. Elevations of onshore locations correspond to the post-earthquake MHHW datum. For offshore locations, to show a height of arriving tsunami, the vertical datum is such that zero corresponds to the pre-earthquake sea level. Dashed lines show water levels after the tsunami for each scenario.
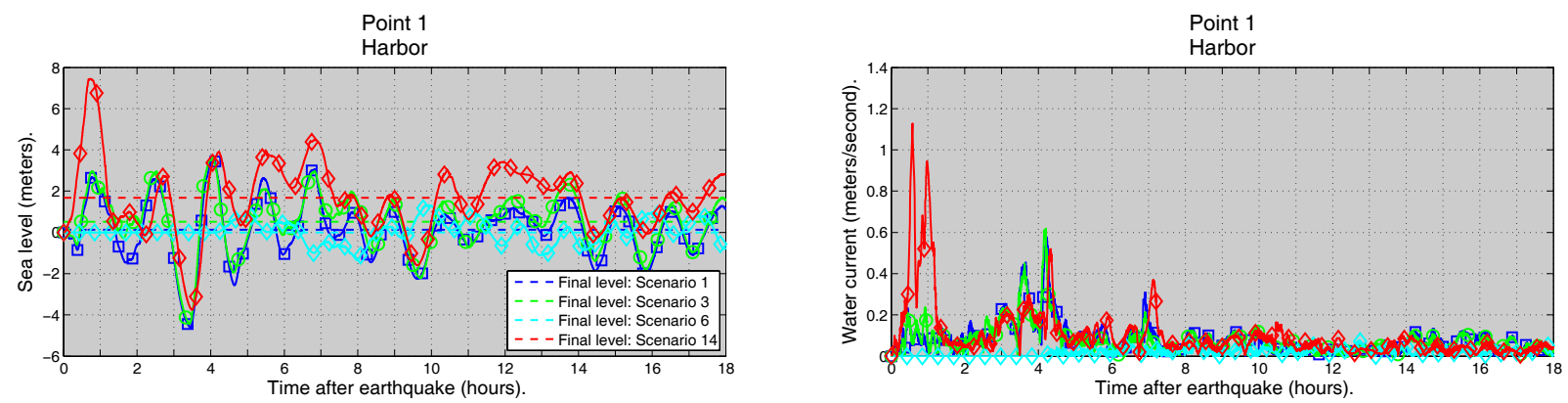

$\square-$ Scenario 1
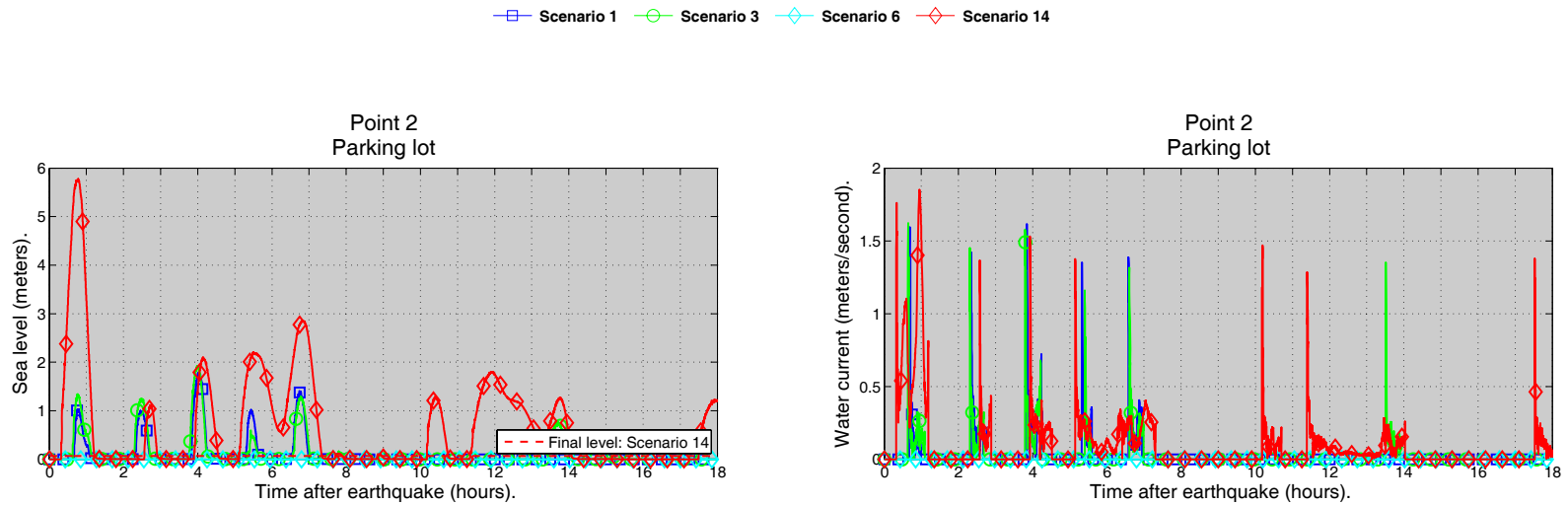

$\square$ Scenario 1, Elevation 1.5m, (4.8ft) $\bigcirc$ Scenario 3, Elevation 1.1m, (3.5t)

Scenario 6, Elevation 1.6m, (5.2ft) $\triangleleft$ - Scenario 14
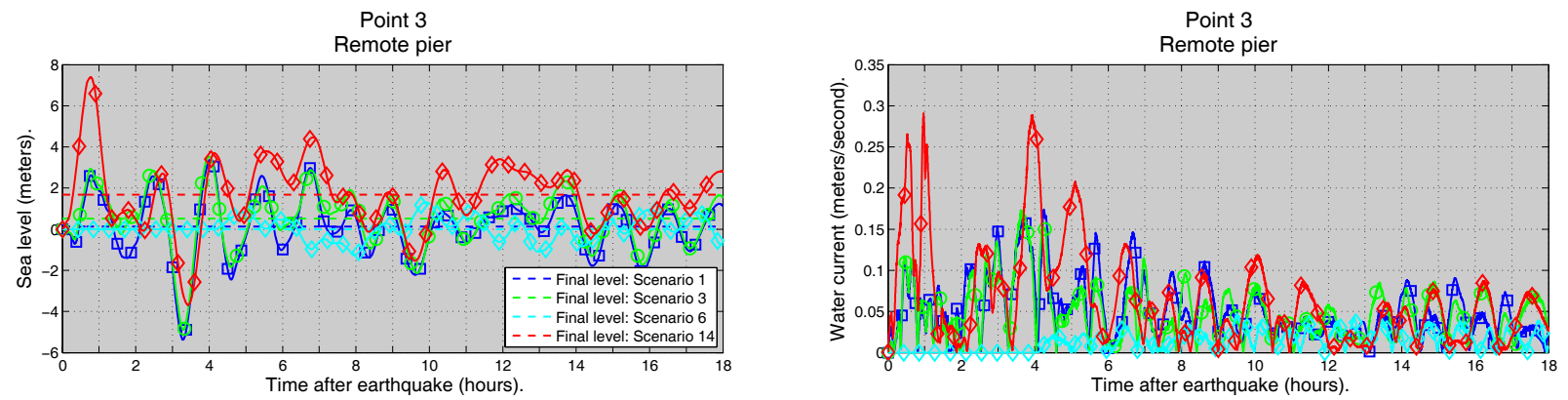

Point 4
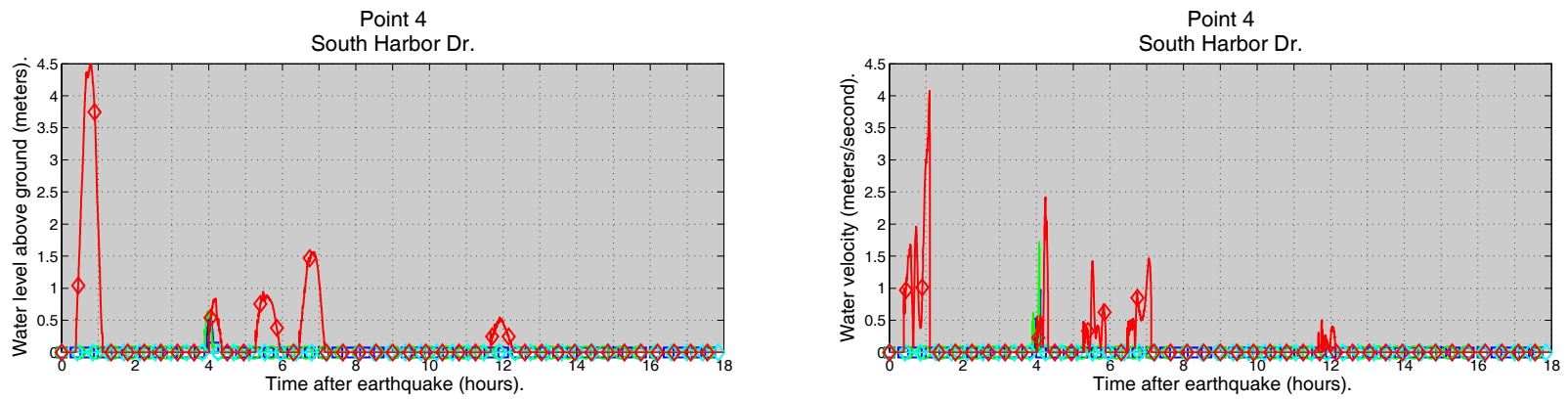

$\square$ Scenario 1, Elevation 2.8m, (9.1ft) $-\bigcirc$ Scenario 3, Elevation 2.4m, (7.8ft) 

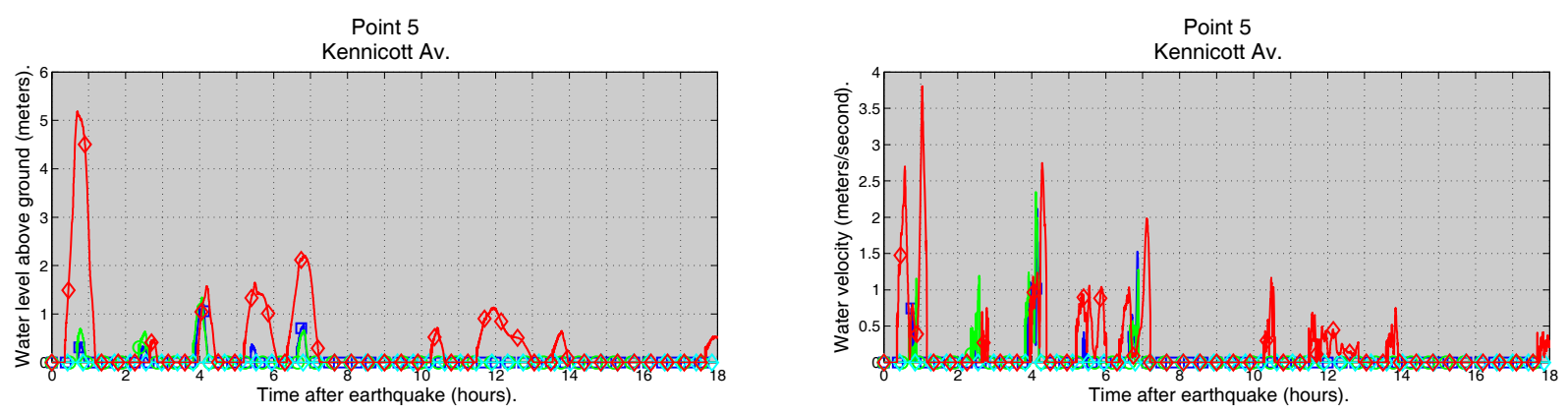

$\square$ Scenario 1, Elevation 2.2m, (7.1ft) $-\odot$ Scenario 3, Elevation 1.8m, (5.8ft)

Scenario 6, Elevation 2.3m, (7.5ft) $\diamond$ Scenario 14, Elevation 0.6m, (2.0ft)
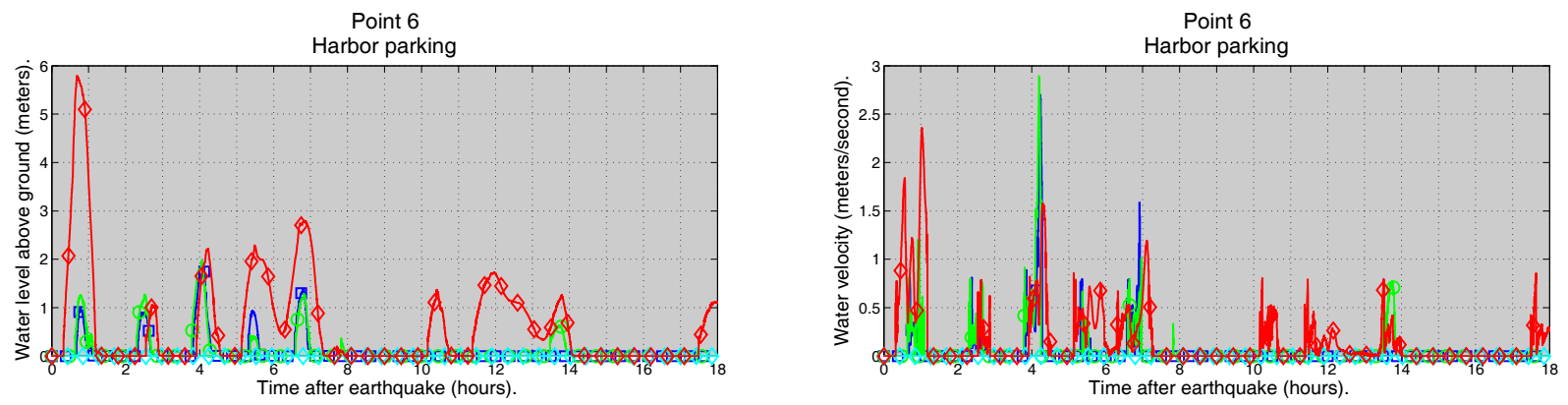

$\square$ Scenario 1, Elevation 1.6m, (5.1ft) $-\bigcirc$ Scenario 3, Elevation 1.2m, (3.9ft)

Scenario 6, Elevation $1.7 \mathrm{~m},(5.6 \mathrm{ft})-\diamond$ Scenario 14 , Elevation $0.0 \mathrm{~m},(0.1 \mathrm{ft})$

Point 7

North Harbor Dr.

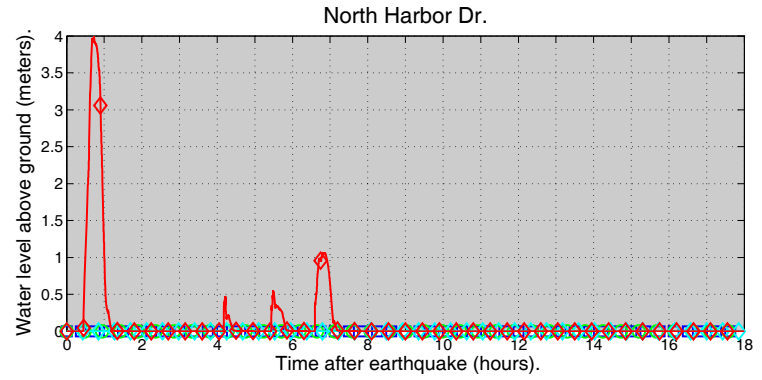

Point 7

North Harbor Dr.

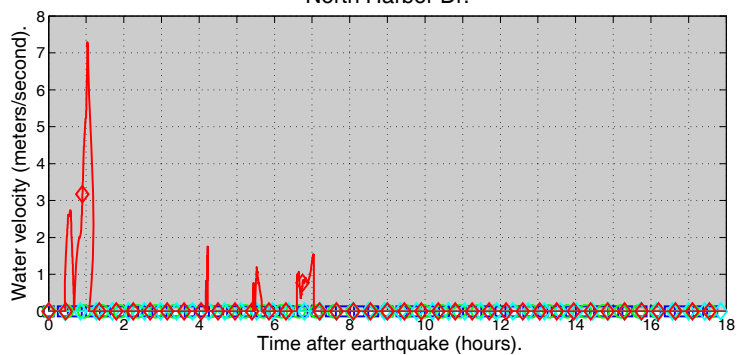

$\square$ Scenario 1, Elevation 3.3m, (10.7ft) $\bigcirc$ Scenario 3, Elevation 2.9m, (9.4ft)

Scenario 6, Elevation $3.4 \mathrm{~m},(11.1 \mathrm{ft}) \diamond$ Scenario 14 , Elevation $1.7 \mathrm{~m},(5.7 \mathrm{ft})$
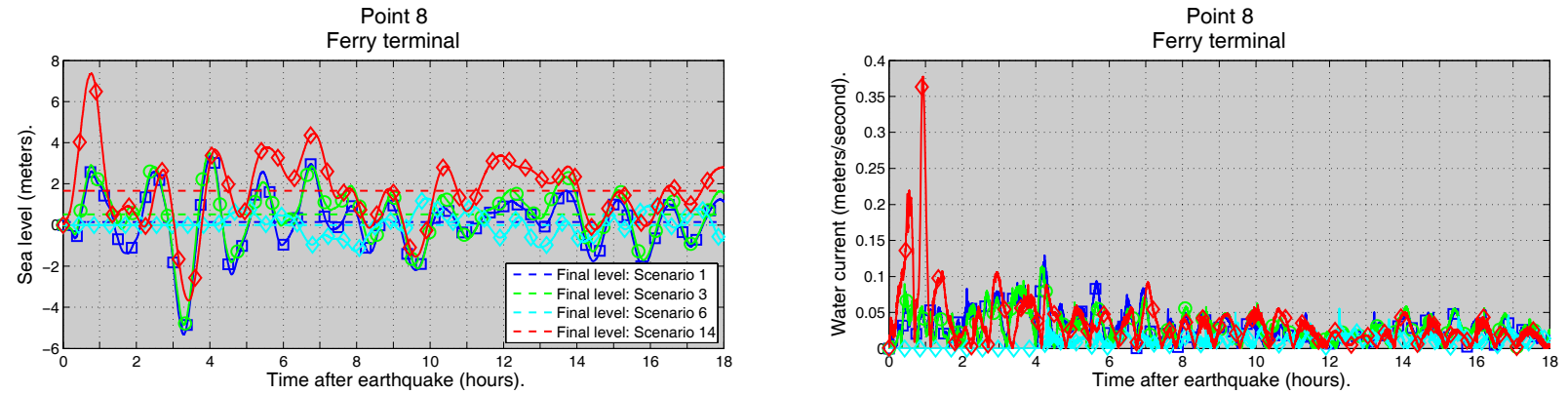

$\square$ Scenario $1-$ Scenario $3 \triangleleft$ Scenario $6 \triangleleft$ Scenario 14 

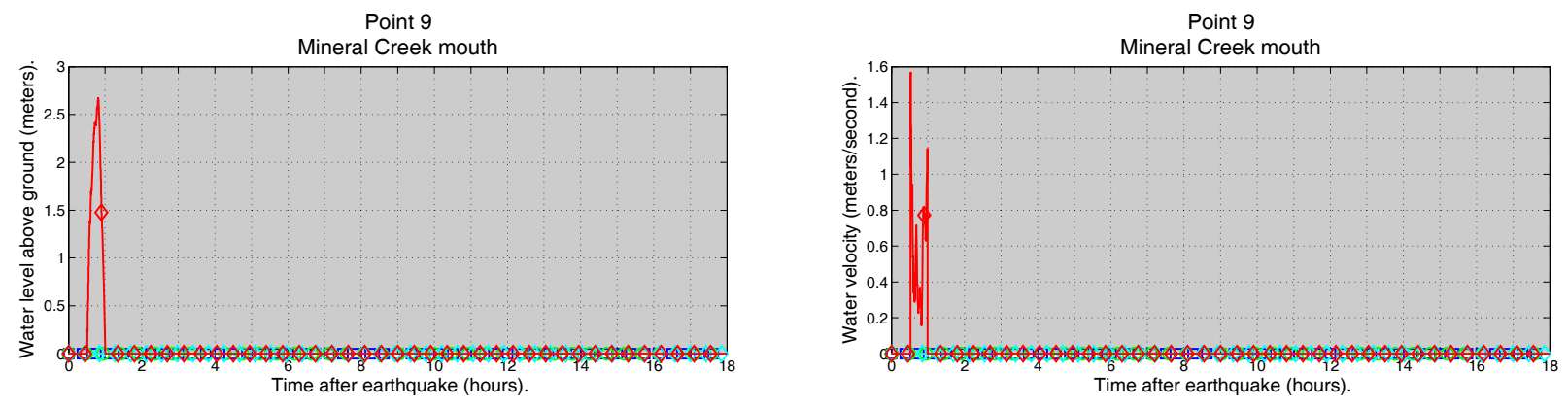

$\square$ Scenario 1, Elevation 4.6m, (15.2ft) $-\odot$ Scenario 3, Elevation 4.3m, (14.0ft)

Scenario 6, Elevation 4.8m, (15.7ft) $\prec$ Scenario 14, Elevation 3.2m, (10.4ft)
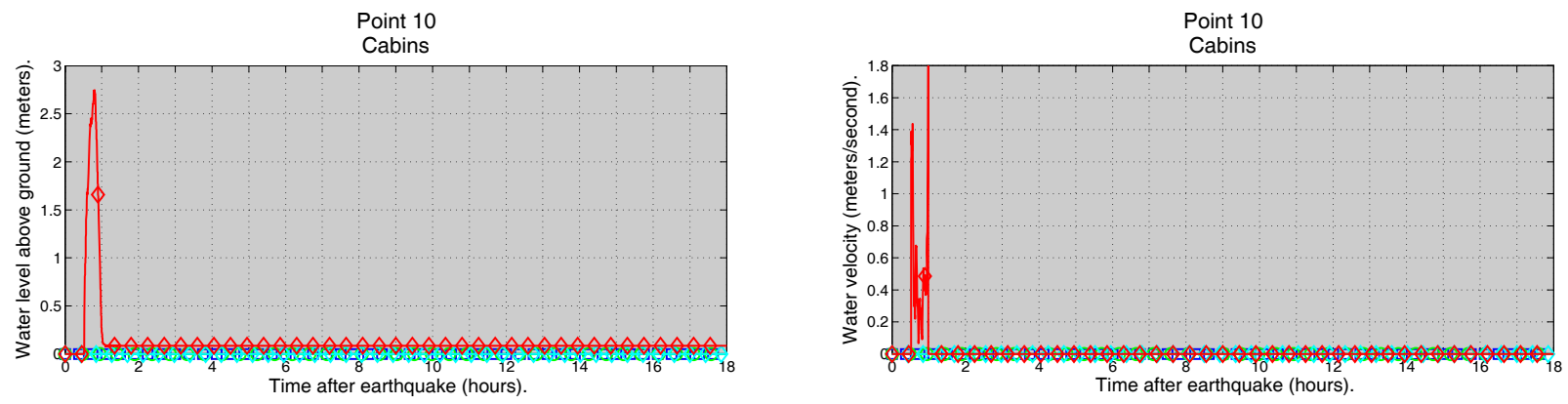

$\square$ Scenario 1, Elevation 4.5m, (14.8ft) $-\quad$ Scenario 3, Elevation 4.2m, (13.7ft) $\longrightarrow$ Scenario 6, Elevation 4.7m, (15.4ft) $\smile-$ Scenario 14, Elevation 3.1m, (10.1ft)
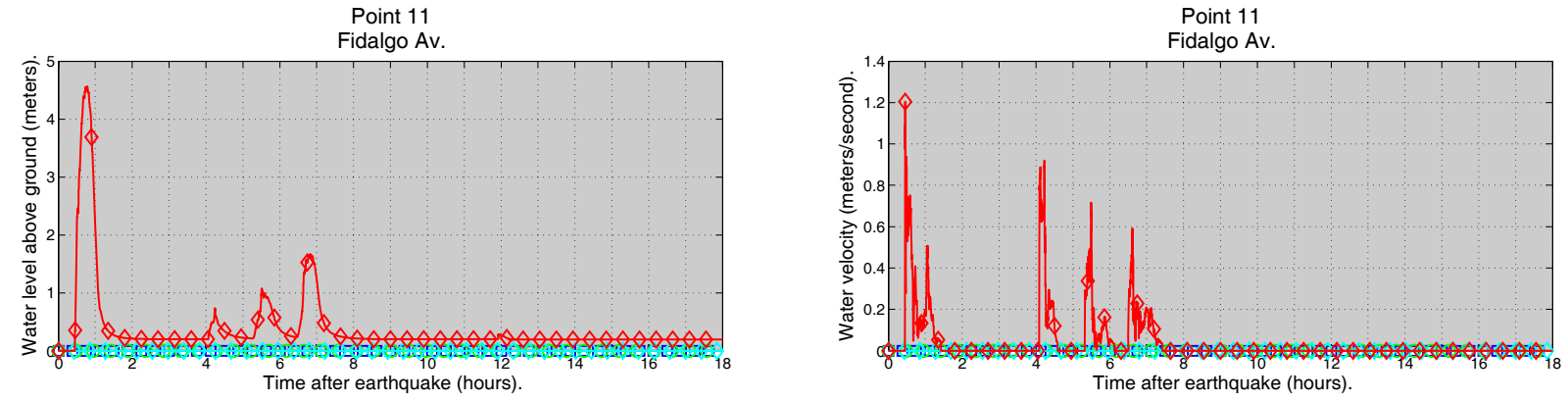

$\square$ Scenario 1, Elevation 2.7m, (8.7ft) $-\odot$ Scenario 3, Elevation 2.3m, (7.5ft) $\succ$ Scenario 6, Elevation 2.8m, (9.2ft) $\succ$ Scenario 14, Elevation 1.1m, (3.7ft)
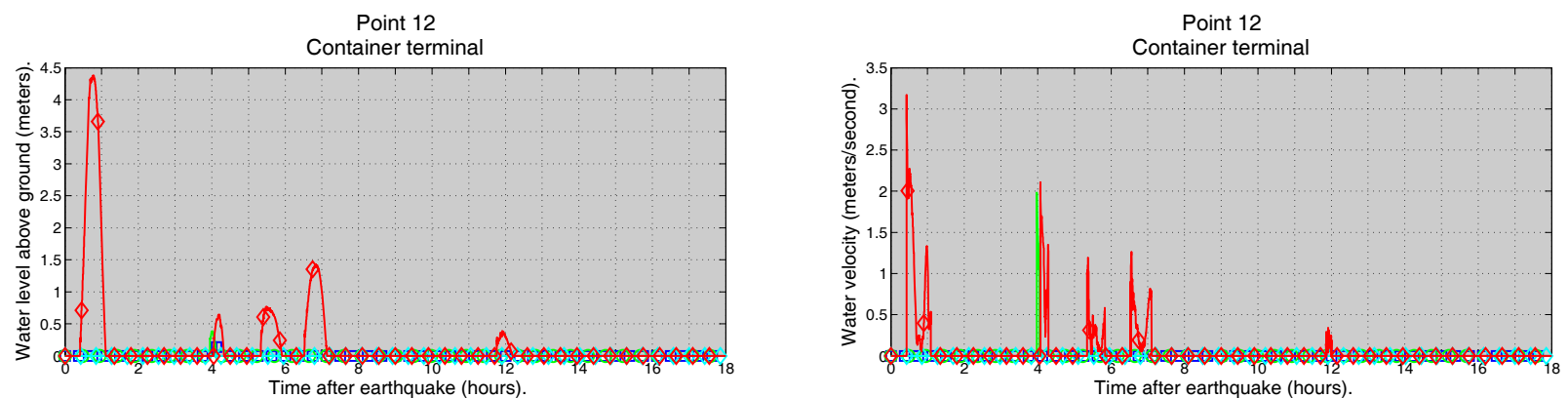

$\square$ Scenario 1, Elevation 3.0m, (9.8ft) $-\odot$ Scenario 3, Elevation 2.6m, (8.5ft) $\checkmark$ Scenario 6, Elevation 3.1m, (10.2ft) $\downarrow$ Scenario 14, Elevation 1.4m, (4.6ft) 

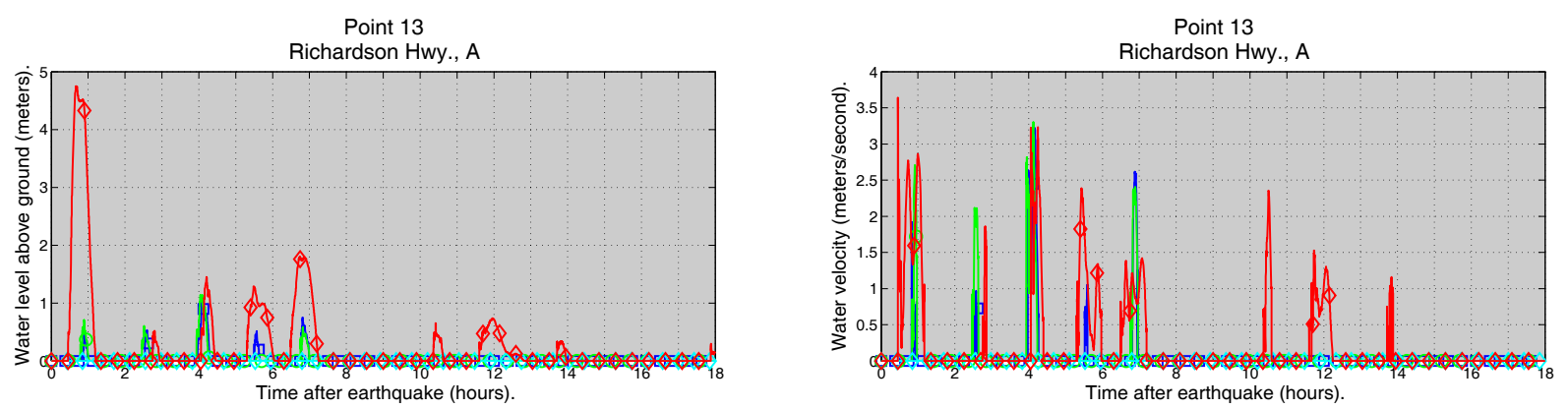

$\square$ Scenario 1, Elevation 2.6m, (8.4ft) $-\bigcirc$ Scenario 3, Elevation 2.2m, (7.1ft)

Scenario 6, Elevation 2.7m, (8.9ft) $\diamond$ Scenario 14, Elevation 1.0m, (3.3ft)

Point 14

Richardson Hwy., B

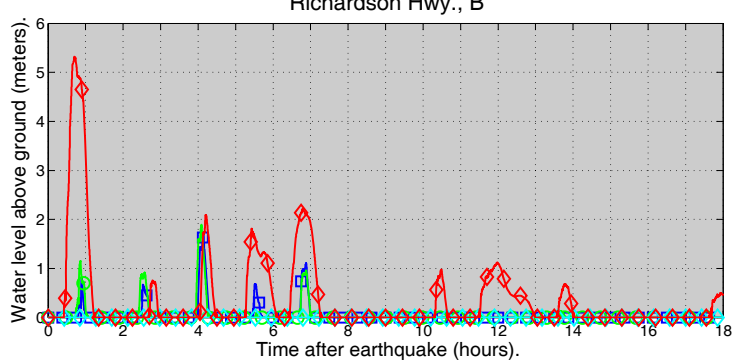

$\square-$ Scenario 1, Elevation 2.3m, (7.4ft) $-\odot$ Scenario 3, Elevation 1.9m, (6.2ft)

Point 15

Richardson Hwy., C

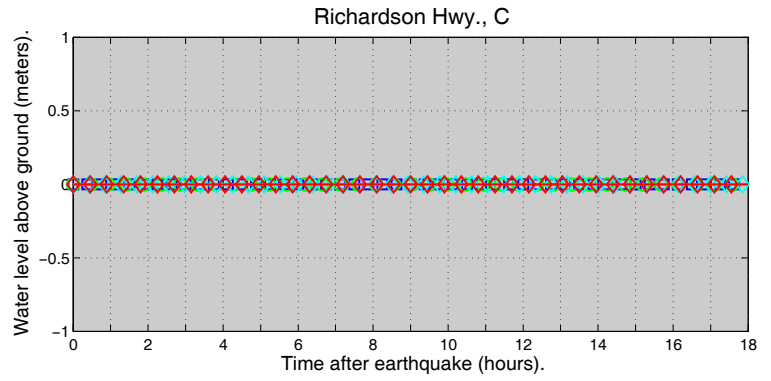

$\square$ Scenario 1, Elevation 8.3m, (27.3ft) $-\bigcirc$ Scenario 3, Elevation 7.9m, (25.9ft)

Point 16

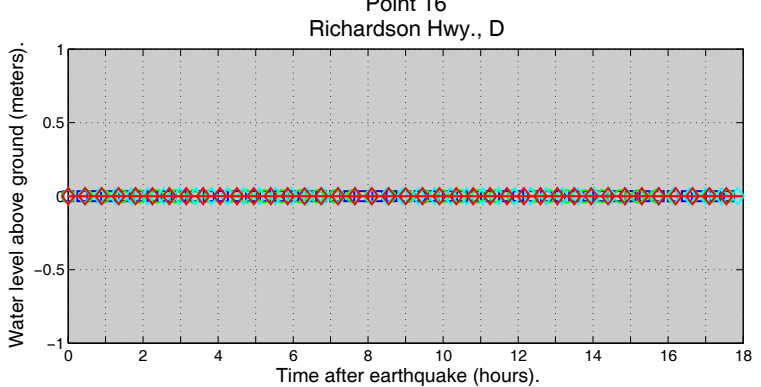

$\square$ Scenario 1, Elevation 12.4m, (40.5ft) $-\odot$ Scenario 3, Elevation 11.9m, (39.0ft)
Point 14

Richardson Hwy., B

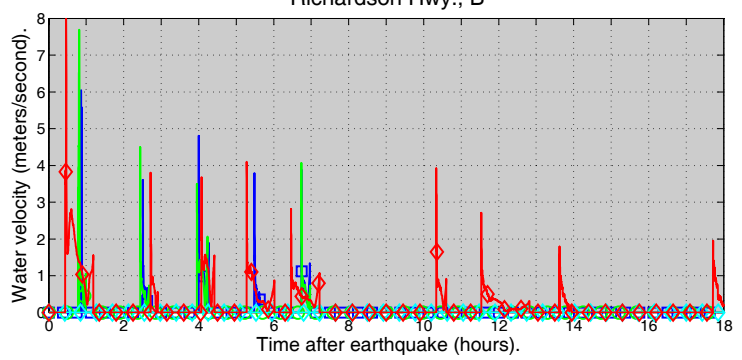

Scenario 6, Elevation 2.4m, (7.9ft) $\succ$ Scenario 14, Elevation $0.7 \mathrm{~m},(2.3 \mathrm{ft})$

Point 15

Richardson Hwy., C

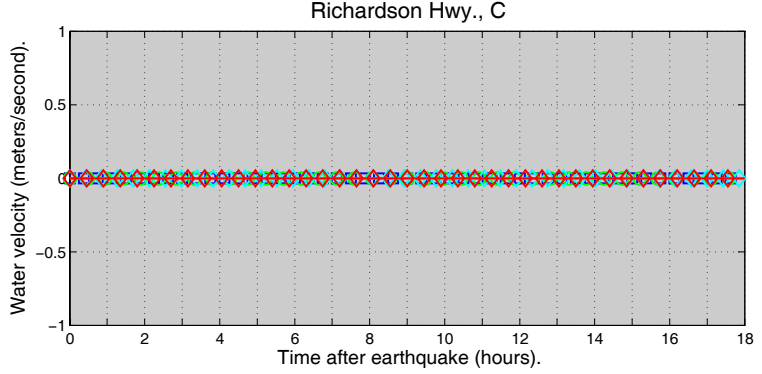

Scenario 6, Elevation 8.4m, (27.5ft) $\downarrow$ Scenario 14, Elevation 6.7m, (21.8ft)

Point 16

Richardson Hwy., D

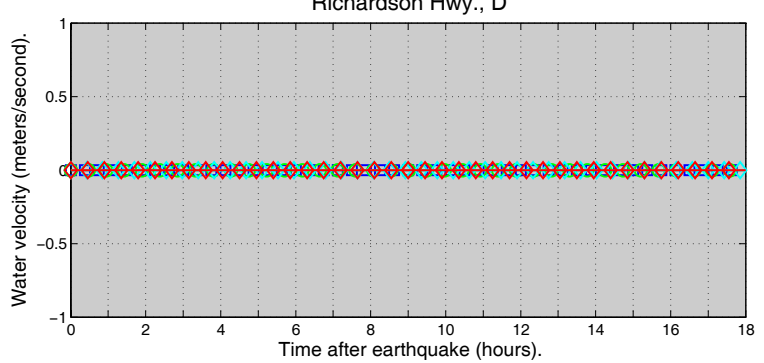



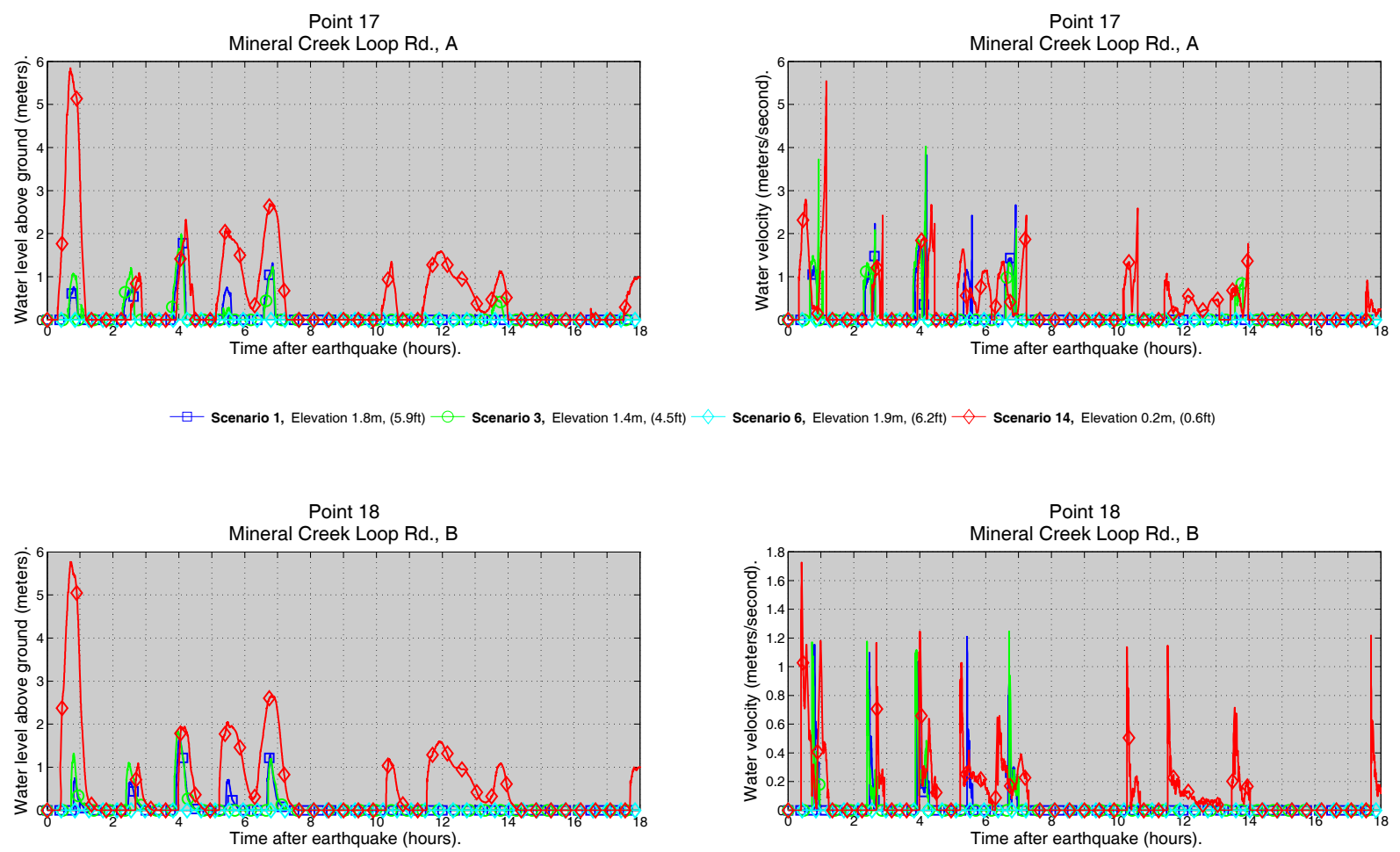

$\square$ Scenario 1, Elevation 1.8m, (6.0ft) $-\odot$ Scenario 3, Elevation 1.4m, (4.6ft)

Scenario 6, Elevation 1.9m, (6.2ft) $\downarrow$ Scenario 14, Elevation $0.2 \mathrm{~m},(0.5 \mathrm{ft})$
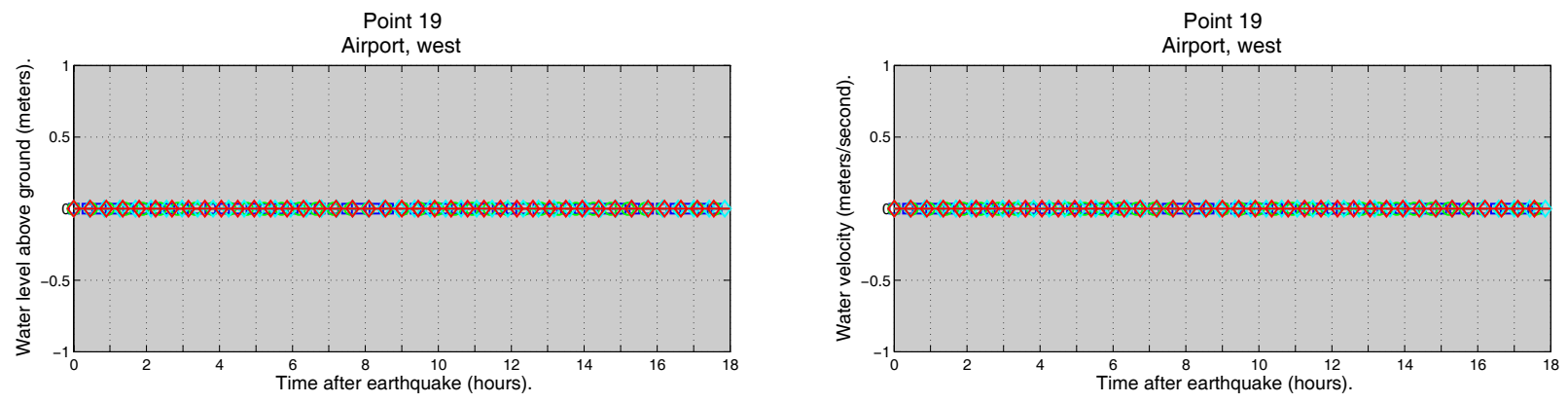

$\square$ Scenario 1, Elevation 12.2m, (40.0ft) $\bigcirc$ Scenario 3, Elevation 11.8m, (38.6ft)

Scenario 6, Elevation 12.3m, (40.3ft) $\downarrow$ Scenario 14, Elevation 10.6m, (34.6ft)
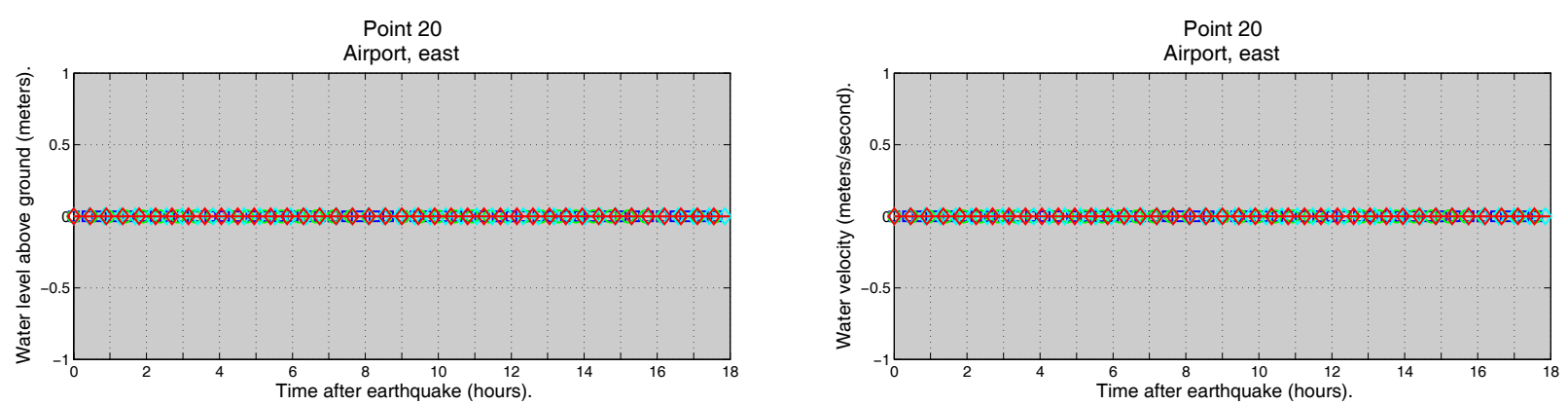

$\square$ Scenario 1, Elevation 35.7m, (117.1ft) $-\odot$ Scenario 3, Elevation 35.3m, (115.7ft) $-\quad$ Scenario 6, Elevation 35.8m, (117.4ft) $\diamond-$ Scenario 14, Elevation 34.0m, (111.6ft) 

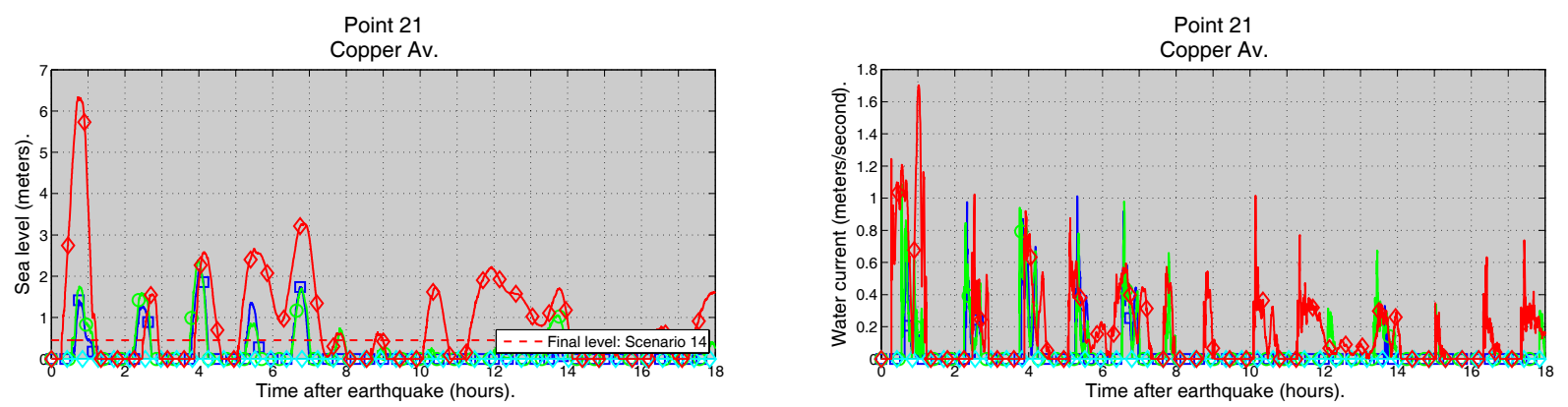

$\square$ Scenario 1, Elevation 1.3m, (4.1ft) $\bigcirc$ Scenario 3, Elevation 0.8m, (2.6ft)

Scenario 6, Elevation $1.3 \mathrm{~m},(4.3 \mathrm{ft}) \smile$ Scenario 14
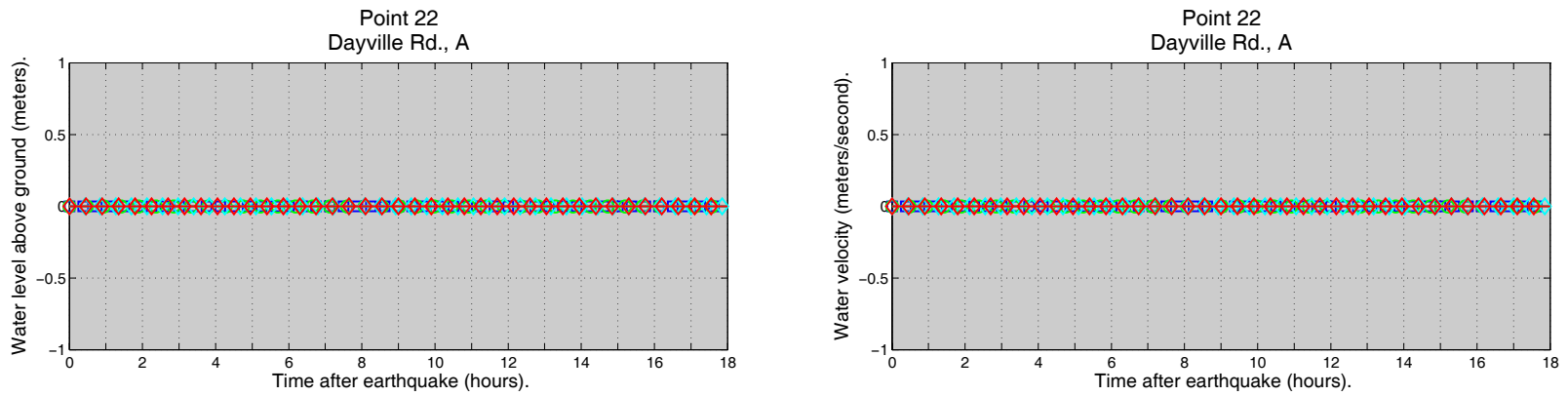

$\square$ Scenario 1, Elevation 10.4m, (34.2ft) $\bigcirc$ Scenario 3, Elevation 10.0m, (32.8ft)

Scenario 6, Elevation 10.5m, (34.4ft) $\diamond$ Scenario 14, Elevation 8.9m, (29.1ft)

Point 23

Dayville Rd., B

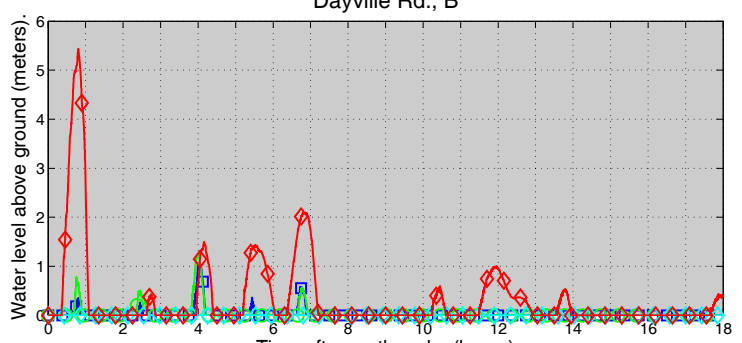

Time after earthquake (hours).

$\square$ Scenario 1, Elevation 2.5m, (8.1ft) $-\odot$ Scenario 3, Elevation 2.0m, (6.6ft)

Point 24

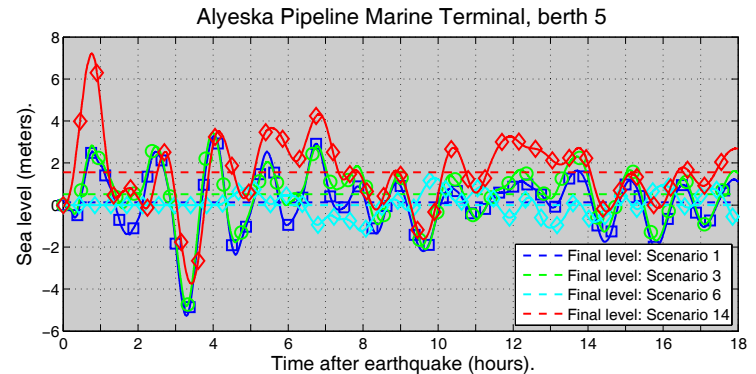

Point 24

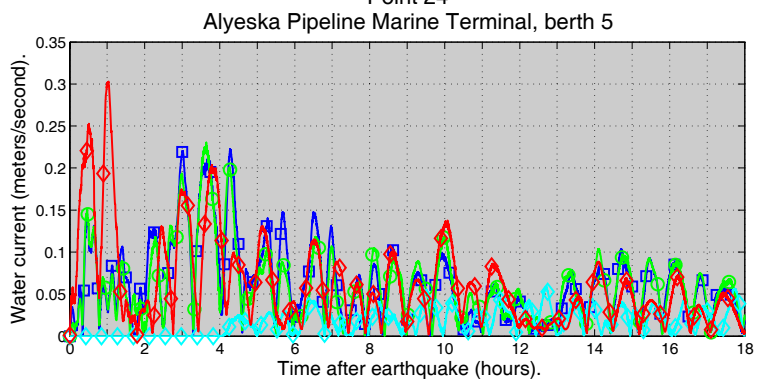

$\square$ Scenario $1-$ Scenario $3 \succ$ Scenario $6 \succ$ Scenario 14 
Point 25

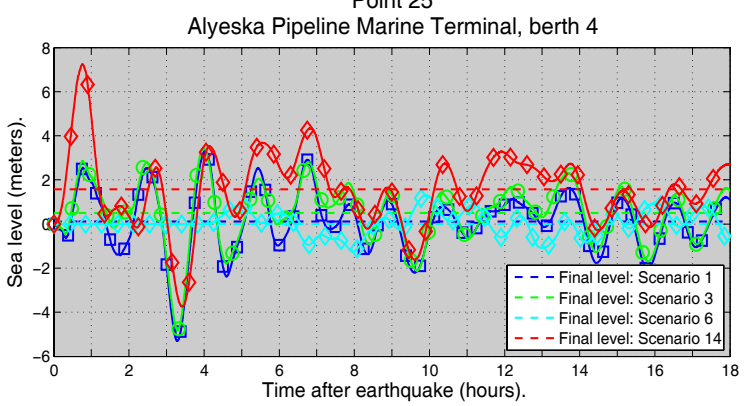

Point 25

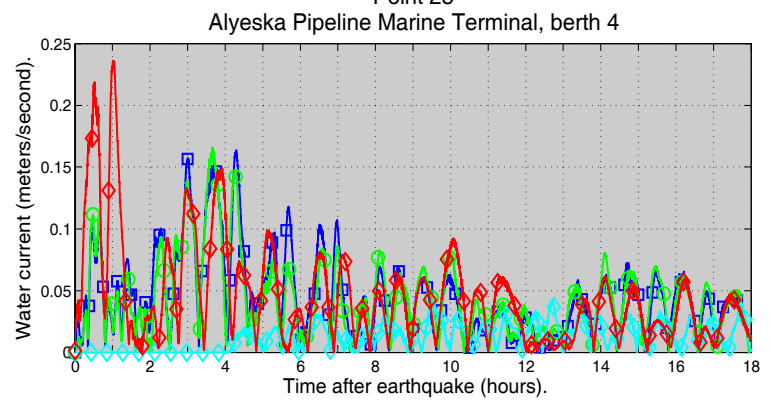

Scenario $6 \triangleleft$ Scenario 14
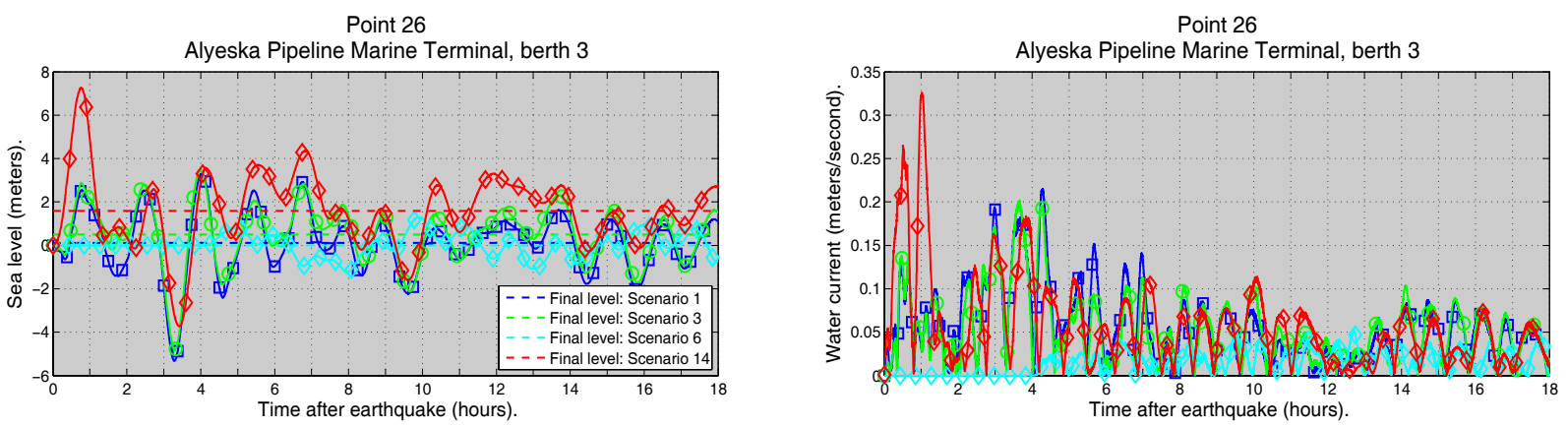

Point 27

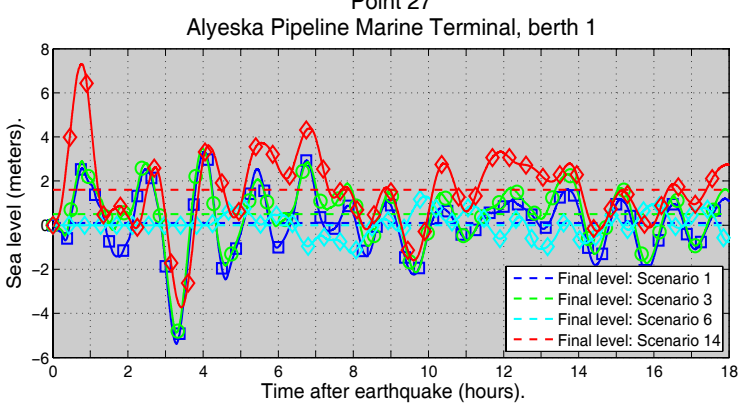

Point 27

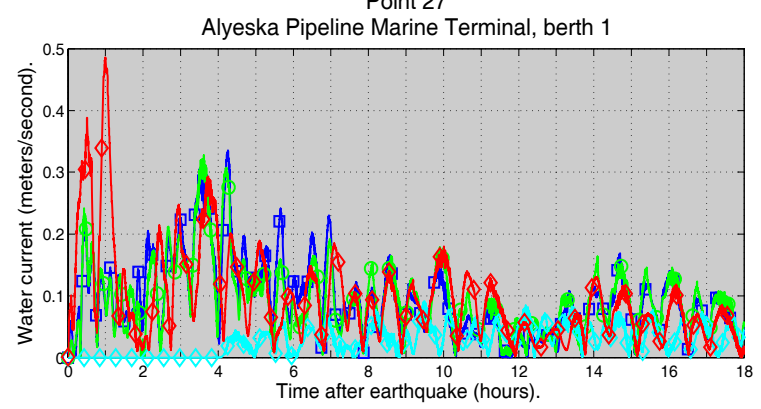

$\square$ Scenario 1

Scenario 3

Scenario $6 \diamond$ Scenario 14

Point 28

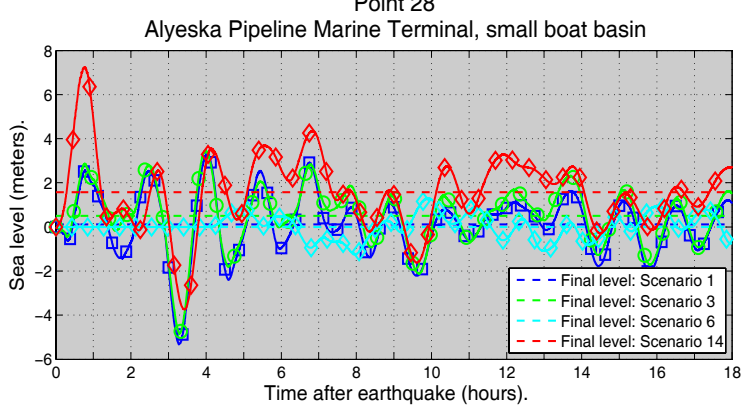

Point 28

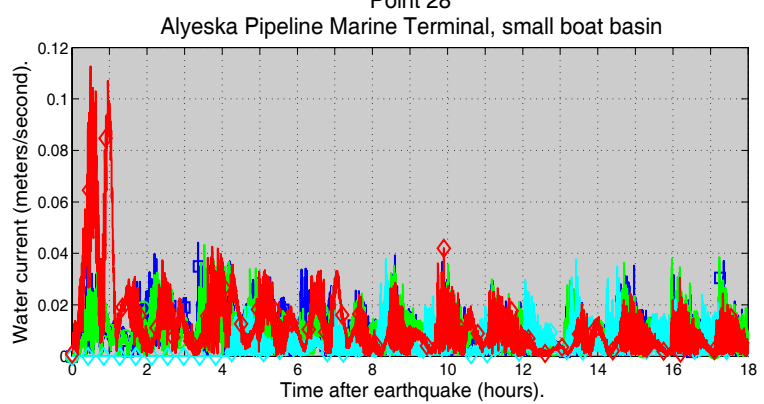

$\neg$ Scenario $1-$ Scenario $3 \triangleleft$ Scenario $6 \succ$ Scenario 14 

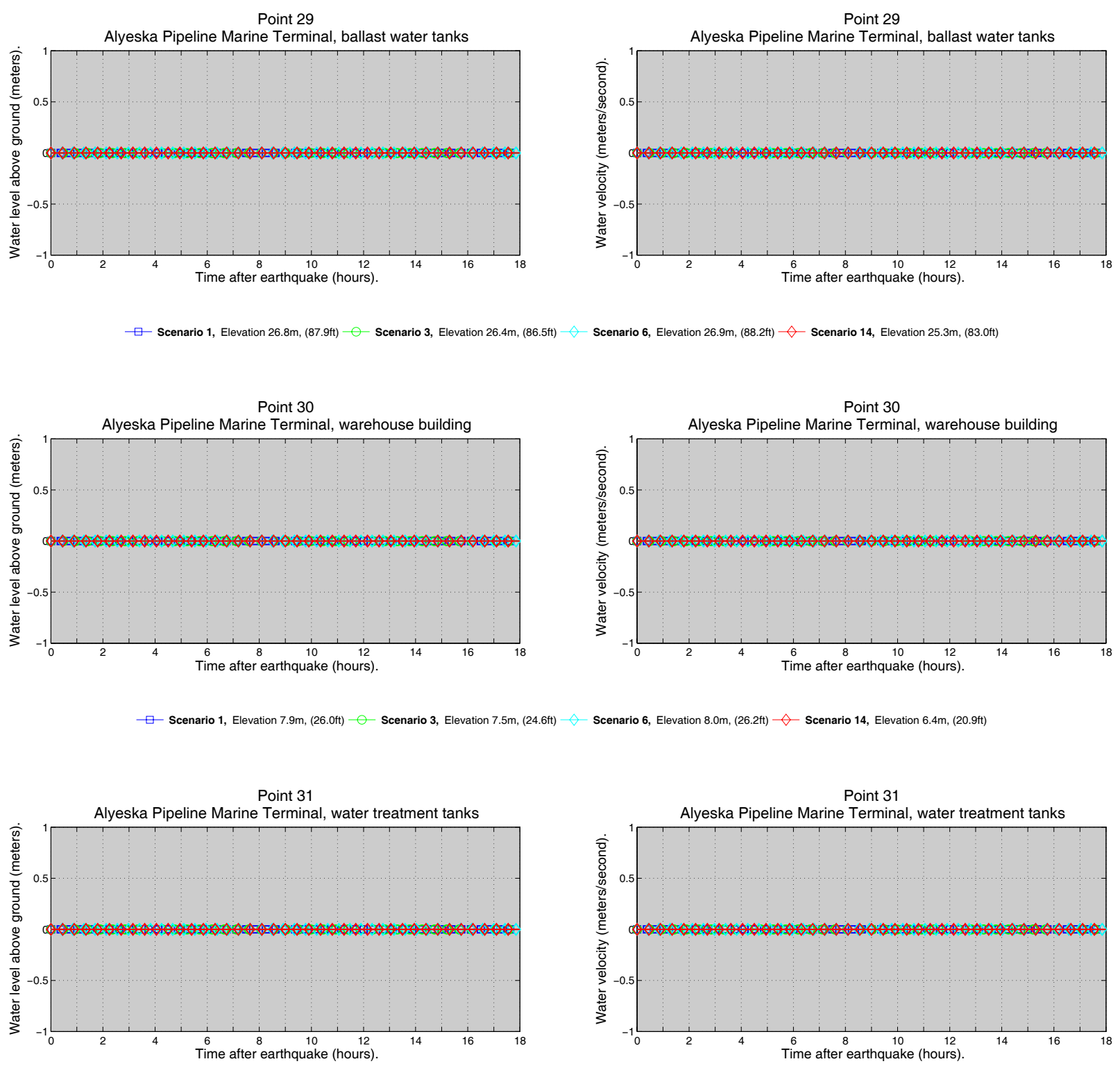

$\square$ Scenario 1, Elevation 12.3m, (40.3ft) $-\square$ Scenario 3, Elevation 11.9m, (39.0ft)

Scenario 6, Elevation 12.4m, (40.7ft) $-\succ$ Scenario 14, Elevation 10.8m, (35.5ft)

Point 32

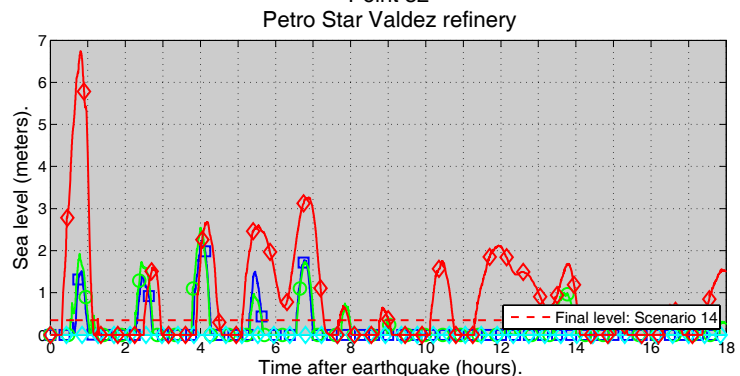

Point 32

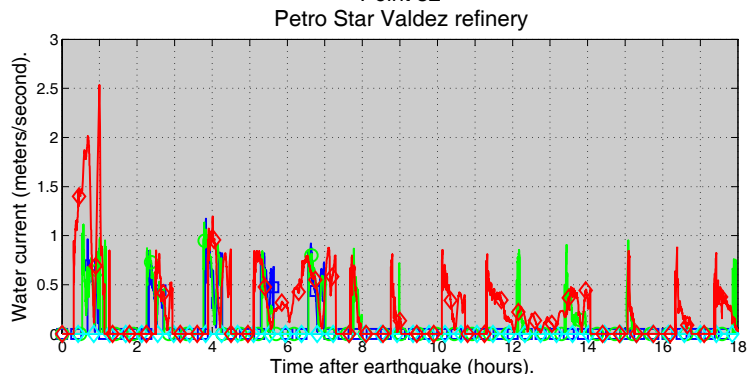

$\square$ Scenario 1, Elevation $1.4 \mathrm{~m},(4.5 \mathrm{ft}) \odot$ Scenario 3, Elevation 0.9m, (2.9ft)

Scenario 6, Elevation 1.4m, (4.6ft) $\diamond$ Scenario 14 
Point 33

Solomon Gulch fish hatchery

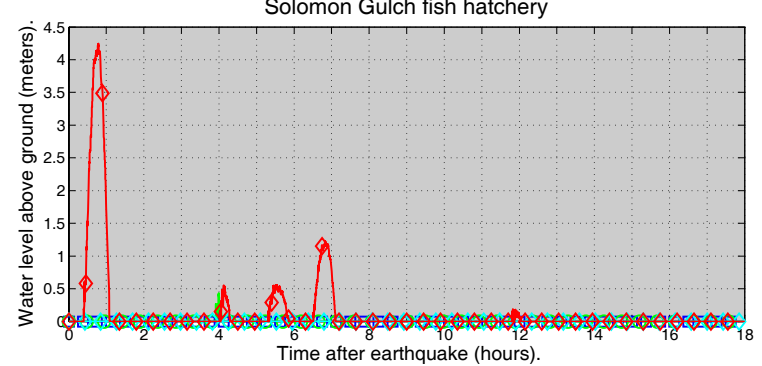

$\square$ Scenario 1, Elevation 3.3m, (10.7ft) $\odot$ Scenario 3, Elevation 2.8m, (9.2ft)

Point 34

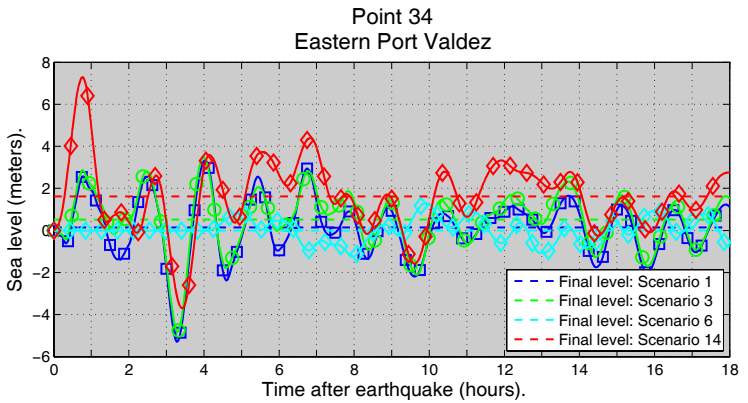

$\square-$ Scenario 1
Point 33

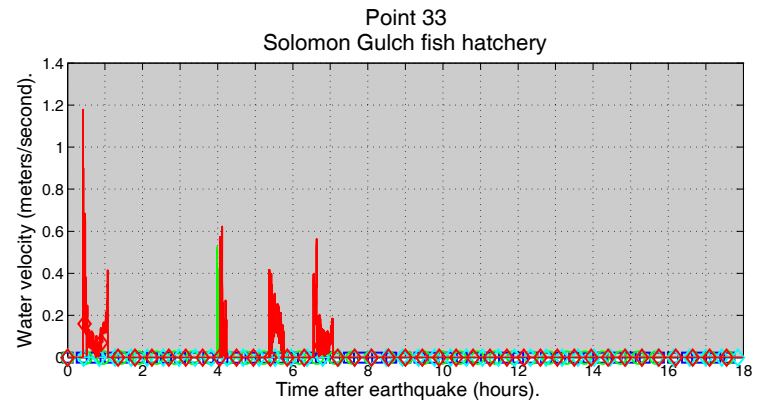

Scenario 6, Elevation 3.3m, (10.8ft) $\diamond$ Scenario 14, Elevation 1.6m, (5.3ft)

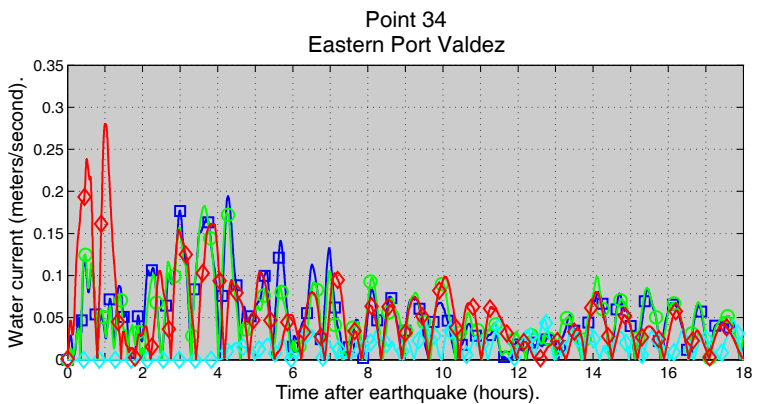

Point 35

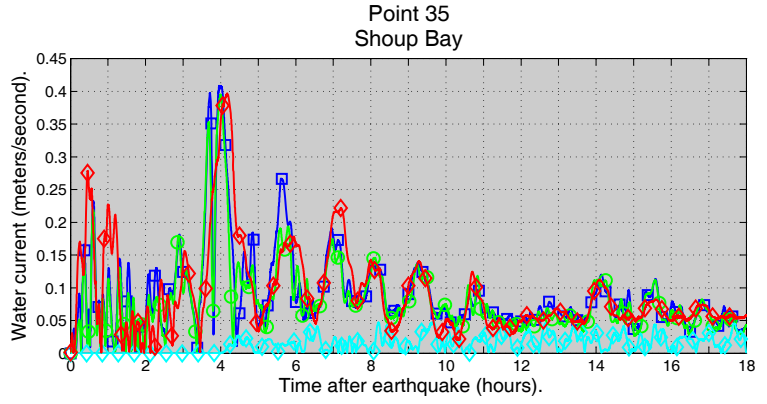

Scenario $6 \triangleleft$ Scenario 14
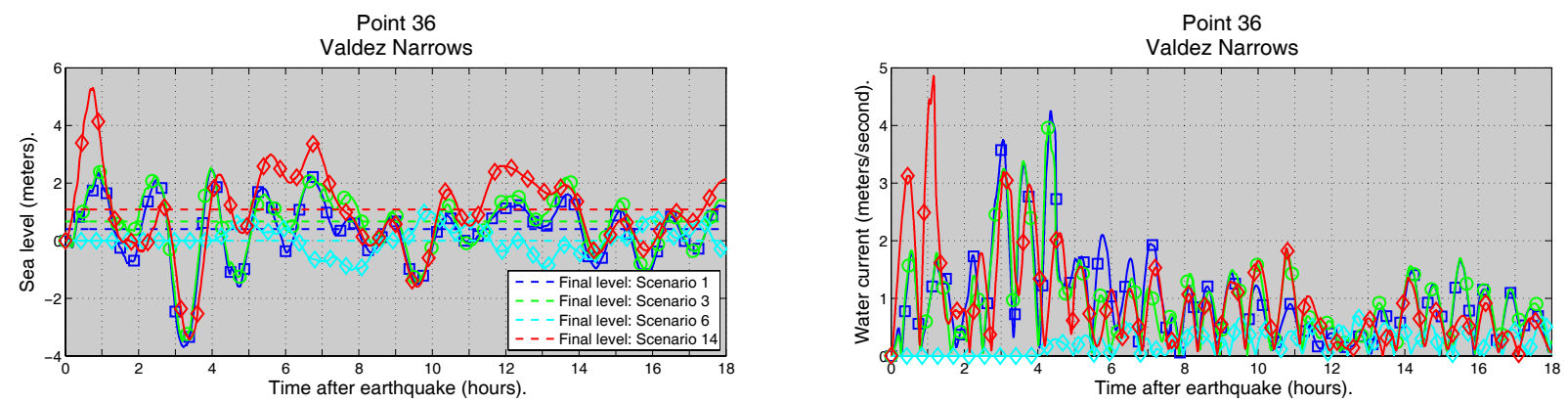

$\square$ Scenario $1-$ Scenario $3 \multimap$ Scenario $6 \succ$ Scenario 14 

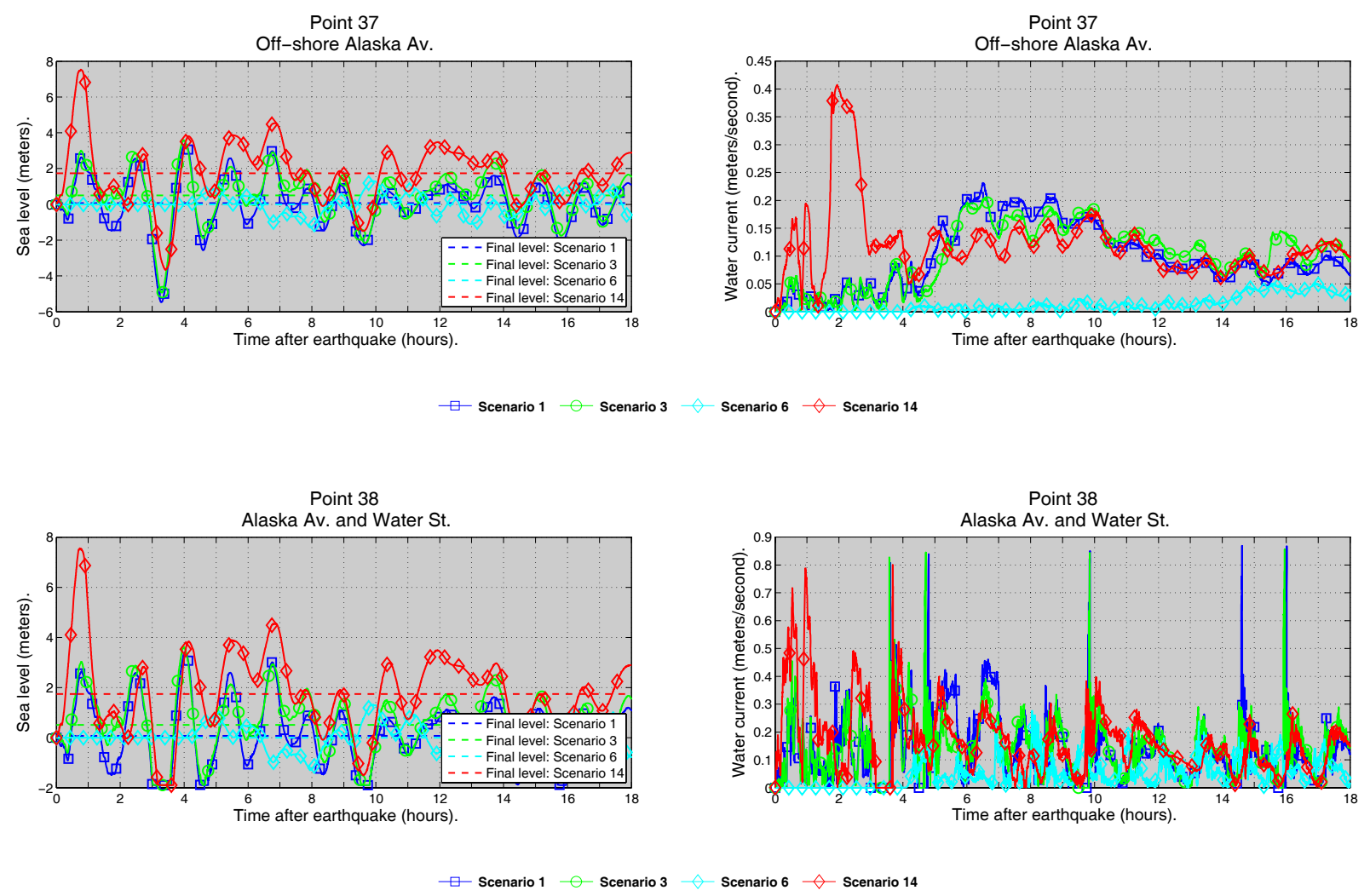

Point 39

Alaska Av. and McKinley St.
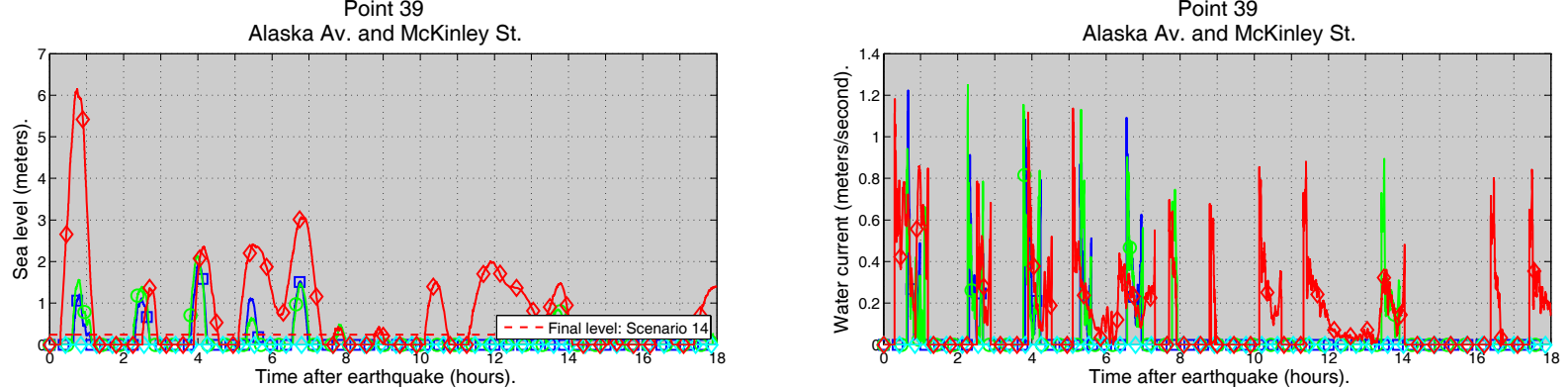

$\square$ Scenario 1, Elevation 1.4m, (4.7ft) $\bigcirc$ Scenario 3, Elevation 1.0m, (3.3ft)

Scenario 6, Elevation 1.5m, (4.9ft) $\diamond$ Scenario 14 